An Angler's

Reminiscences

By

Charles Hallock 

Digitized by the Internet Archive in 2007 with funding from Microsoft Corporation 


$$
\frac{10.52}{3}
$$




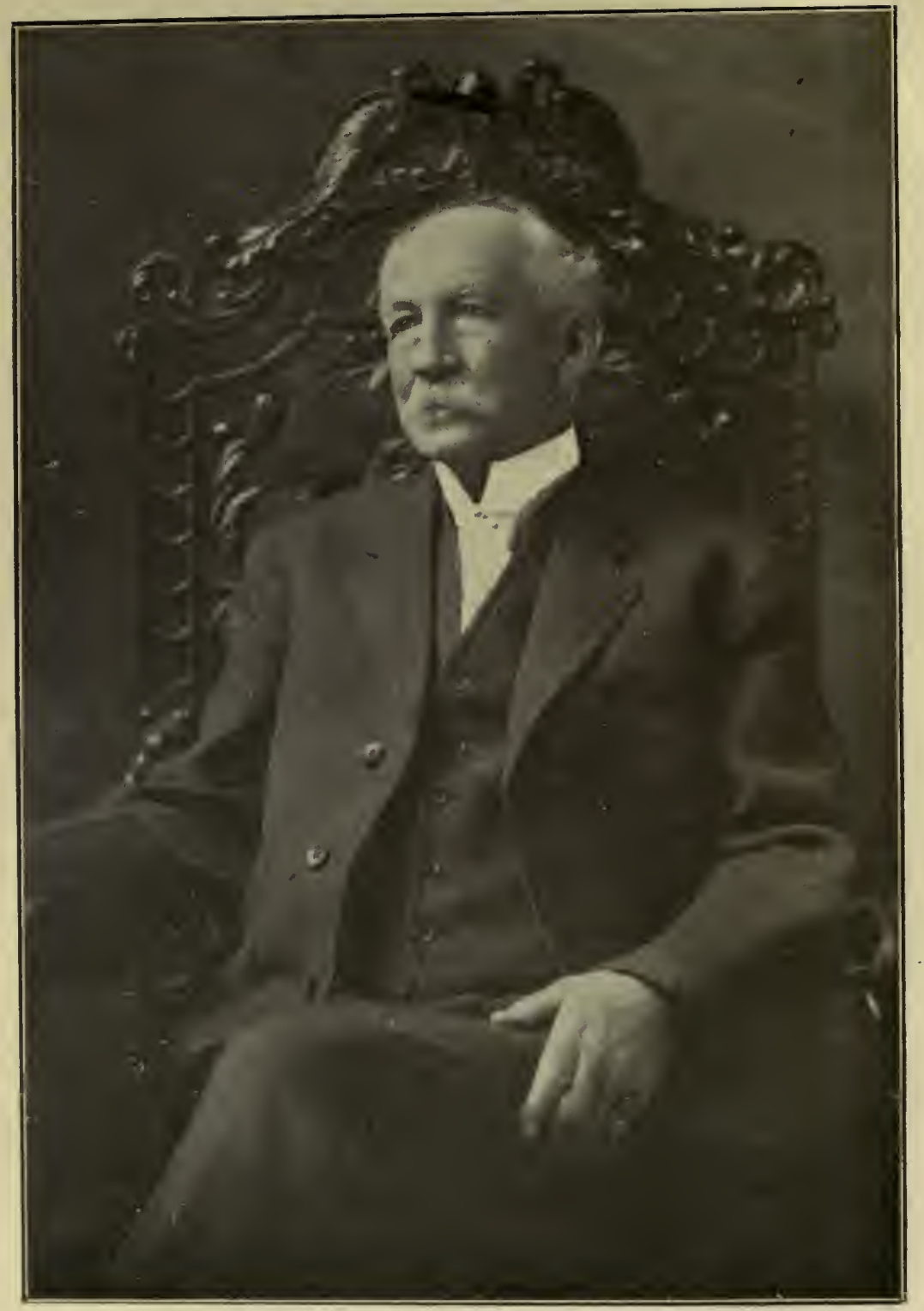

MR. CHARLES HALLOCK. 


\title{
AN ANGLER'S REMINISCENCES.
}

\author{
A RECORD OF SPORT, TRAVEL \\ AND ADVENTURE.
}

WITH AUTOBIOGRAPHY OF THE AUTHOR.

\author{
BY \\ CHARLES HALLIOCK, \\ "DEAN OF AMERICAN SPORTSMEN." \\ Author of "The Fishing Tourist," "Peerless Alaska," \\ "Sportsmen's Gazetteer," Etc., Etc.
}

\author{
Notes and Introductory Chapter \\ by \\ FRED E. POND:("WILL WILDWOOD.")
}





\section{CONTENTS.}

Introductory Chapter....................................... VII

CHAPT. $\quad$ PAGE

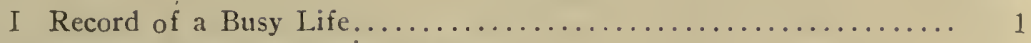

II Angling Days and Angling Vriters..................... 10

III Fishing Jaunts and Angling Associates................... 1 i

IV Early Recollections............................... 25

V In the Sunny South................................. 34

VI A Sojourn in Florida.............................. 38

VII The IVild West.................................... 42

VIII Literary Work and Travel........................... 46

IX Park Region of Minnesota........................... 53

$\mathrm{X}$ The Undine Fishing Party Under Fire................... 56

XI Random Casts in the Land of Lakes...................... 60

XII A Perilous Adventure at Kanawha Falls.................... 64

XIII The Princess and the Salmon......................... 68

XIV Trouting on Long Island-Opening of the Season............. 74

XV American Angling Literature........................... is

XVI A June Rise on the Godbout......................... $8 i^{\circ}$

XVII Anent the Salmon............................... 90

XVIII Let Us Commune Together......................... 94

XIX Arctic Fishing in Subtropical Waters...................... $9_{i}$

XX The New Dispensation of Fishes....................... 100

XXI Bobling for Eels .................................. 104

XXII Why Fish Don't Always Bite, etc...................... 106

XXIII "Fysshe and Fyssheynge"............................ 111

XXIV "Fysshe and Fyssheynge" (Concluded).................. 118

XXV Progressive Fish Culture............................ 124

XXVI Record of Life Work for Fifty-Eight Years................ 127 


\section{ILLUSTRATIONS.}

Portrait of Charles Hallock-Frontispiece. PAGE

Hallock Castle.................................. 11

Salmon Spearing on the Restigouche ....................... 13

Mt. Katahdin from Near Abol Carry...................... 15

Domine Olmstead and Mr. Charies F. Hotchkiss.................. 16

Mr. Walter M. Brackett and Mr. Colin Campbell.................. 18

Com. J. U. Gregory and Mr. IV. F. Whitcher................... 19

Mr. Allan Gilmour and Allan Gilmour's Fishing Camp.............. 21

Flatheads and Prospectors at Kalispel, Mont................... 23

Early Railroad Train in Florida......................... 40

Mr. Fayette S. Giles and Mr. H. H. Thompson................ 47

Fort George Island Hotel. ............................ 73

Salmon Fishing on the Miramichi River.................... 93

FULL PAGE PORTRAITS.

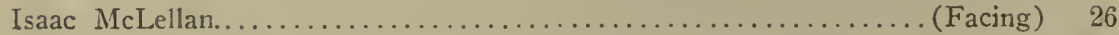

Spencer F. Baird................. " 32

Dr. A. J. Iroodcock.......................... " 42

Friends of Charles Hallock...................... " 46

Dr. W. F. Carver.................. " 50

ivim. C. Harris ..................... " 94

Robert B. Roosevelt............................ " 102

Fred. Mather......................... " 124

Prof. G. Brown Goode............................. " 126

Charles Hallock Under Ancestral Trees.................. " 132 


\section{INTRODUCTORY.}

ChaRles Hallock's literary career, covering a period of sixty years-beginning with the editorship of a college paper, "The Scorpion," at Amherst, in 1852-has been remarkable for wide range, and thorough mastery of each subject. Although angling has always been his favorite recreation his active participation in other manly outdoor sports is indicated by the title, "Dean of American Sportsmen;" conferred by prominent brothers of the guild in recognition of his ability as a practical exponent of healthful pastimes, and as an author-an acknowledged authority-in this branch of literature. Turning to the brief autohiography in this volumea classic in its special line-the reader will find some of the salient features of a life work great in achievement, varied in scope-from scientific research to current comment on the topics of the day; from sojourning in the Sunny South to pioneer jaunts in the wild West and to far-off Alaska-yet interspersed always with pursuit of the pastimes he loved, with rod and gun.

His recreations-like those of "Christopher North"-furnished material for delightful sketches, standard works, scientific essays. His companions were men of action-the hardy voyagcurs, at home in primitive craft on wild waters, or on foot along wild trails; ardent anglers seeking adrenturous sport on salmon -rivers and trout streams far from routes of ordinary tourists; scholars and scientists delving deep in the study of animated nature.

That Charles Hallock is and has long been a recognized force, an accepted authority in matters pertaining to fish and fishing, science and travel, is evidenced by the fact that he is an active or honorary member of no less than fifty-seven clubs and associations, many of these being organizations of national and some of international scope. His copyrighted hooks are seventeen in number, and his various articles in the magazines, sportsmen's journals and daily press would, if collected in library form, fill fifty volumes of absorbing interest. The condensed summary, given elsewhere in this work, records the remarkable fact that outside of newspaper work his occupations and important expcriments reached a total of sixty-seren, while his hairbreadth escapes numbered twenty-eight.

As an editor, particularly in his favorite field, he posscssed the qualifications to acquire the full measure of success. His literary style was here shown in its versatile character, its vigor, and perfect command of the English language. A valuable adjunct was his world-wide acquaintance with men of nark in sportsmanship and the world of letters. He probably knew personally a larger percentage oi his prominent contributors than any predecessor in the realm of sportsmen's 
journalism, with the possible exception of William T. Porter-the honored pioneer, termed "York's Tall Son," by reason of his personal popularity and his height of six foot four.

The chronological record of Charles Hallock's literary work gives ample evidence of his versatile ability as a writer. It may not be generally known that he has written a number of creditable poems, replete with humor and sentiment, the most noteworthy of these being "California," an epic illustrating frontier life in the Golden State; "New Year's Calls," a parody on "Marco Bozarris;" the "Legend of Kill Devil Hole;" "My Briarwood Pipe," and "An Ode to a Nose."

This volume, "An Angler's Reminiscences," first appeared as a serial in the columns of The Sportsmen's Review, attracting widespread attention, and the chapters on fish and fishing-with an autobiography from the graphic pen of the Dean himself-have been selected to make up a book of interest to all who love the great out-of-doors and appreciate the classic literature of angling. It is a worthy companion piece to place on the library shelf with Charles Hallock's "Fishing Tourist," the earliest of his published volumes, issued forty years ago, and will be regarded as a crowning work of a long life of honorable achievement.

To the writer the task of collecting and selecting the chapters for preservation in book form proved highly enjoyable, and while minor mistakes have doubtless crept in, on account of lack of time to carefully collate from the serial in the Sportsmen's Review, it is hoped the reader will generously overlook the errors of the editor, or at least place responsibility for these on the writer of this brief Introductory, who has gathered a boquet of choice flowers-"with nothing of his own except the cord that binds them."

Will. WILDWoOn. 


\section{CHAPTER I.}

RECORD OF A BUSY LIFE.

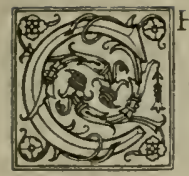

HARLES HALLOCK, editor, author and naturalist, was born in New York City March 13, 1834, son of Gerard and Eliza (Allen) Hallock. The family was founded in America when Peter Hallock (or Holyoake) located at Southold, L. I., thirteen colonists, led by Rev. John Young, of Hingham, Norfolk County, England, who landed in New Haven, Conn., October 21, 1640. He subsequently received from Governor Dougan, under James II., a grant of 40,000 acres of land lying between Southampton and Montauk Point. The obituary notice of IVilliam, son of Peter, the founder of the Southold Colony, who died September 30, 1684, and is so recorded, is spelled Holyoake.

Through his mother he is descended from Rev. Thomas Mayhew, Governor of Nantucket and Martha's Vineyard, under a grant from Lord Sterling in 1614. Of their descendants, one branch became Quakers, and to this Fitz Greene Halleck, the poet belonged; others comprised among their numbers eminent fighting men, distinguished in the American revolution and since, both on land and sea. During the revolution Joseph Hallock fell as commander of a privateer; William Halleck commanded packet boats on Long Island Sound; another William Hallock owned and commanded a vessel sunk by the English ship Snow, and had two sons, Jeremiah and Moses, who were also soldiers of the revolution. During the Civil War many members of the family fought in support of the Union, notably MajorGeneral Henry W. Halleck.

A portion of Charles Hallock's life was passed on his uncle's farm, at Plainheld, in a wilderness section of the Green Mountains in Massachusetts, where he imbibed those tastes for outdoor sports and adventure which so largely shaped his course through life. In those youthful days he occupied a secluded shooting box on the estate in preference to the farm house, except in coldest winter weather.

Having fitted for college at Hopkins Grammar School, in New Haven, Conn., he entered Yale in 1850, but subsequently went to Amherst, where, in 1852, during his sophomore year, he printed a college paper named the Scorpion. This seems to have been his first journalistic venture, and the taste for newspaper work then imbibed, or more probably inherited from his father, who was at that time the active head of the New York Journal of Commerce, induced him to discontinue his collegiate course of study early in the junior year and enter the printing office of his father. There he mastered the rudiments of a journalistic education. Although not a college graduate, the faculty of Amherst subsequently conferred upon him, in 1871, the degree of A. B. Extraordinary, the first honor of the kind which it had conferred. In the spring of 1855 he attached himself to the New Haven Register, and conducted that paper for a year and a half for its proprietor, M. A. Osborn, Esq., then collector of the port. In August, 1856, he accepted a salary and onesixteenth proprietary interest in the Journal of Commerce, and remained until September, 1861, when the political troubles threw him out of his chair, but not of his ownership in the paper, which at that time had increased to about one-tenth. 
During these nine years of his editorial life Mr. Hallock did not confine himself to office duties. He was constantly on the move, taking trips of several months' duration at sundry times-first to the Rocky Mountains (a different journey then than now), then to the Red River country in British North America, next to Labrador, in 1860 , when he headed an expedition to view the total eclipse and collect birds for the Smithsonian Institution, in connection with Elliott Coues, and at other times to Newfoundland, Cape Breton, and remote parts of Canada, accounts of which trips appeared from time to time in Harper's Magazine, illustrated by his own pencil, and which of course earned for him the right to be classed with the magazine. writers of the period. Of those contributions of his which are annonated in the Harper index, we find: "The Siege of Fort Atkinson (a story of Indian strategy on the plains), "The Red River Trail," "Life Among the Loggers," "Aroostook and the Madawaska," "Three Months in Labrador," "IVild Cattle Hunting on Green Island," "The Racket Club," and "Secrets of Sable Island." He also wrote numerous novelettes for the weeklies and a series of western border sketches for the Spirit of the Times over the signature of "Lariat," exhibiting no especial mark of genius, perhaps, but sufficiently creditable for a young man of his age.

During a period of the war, in 1863 , Mr. Hallock edited the Augusta (Ga.) Chronicle and Sentinel, in conjunction with N. B. Morse, Esq., afterwards of the New York Daily News, running the blockade overland into the Confederacy, and out again from Wilmington, N. C., to Bermuda by steamer, a graphic account of the trip and of the Enchanted Isles, afterward appearing in the Galaxy Magazine. While in the south he published a biographical sketch of General Stonewall Jackson, fifty-eight pages octaro, issued eighteen days after his death, which was afterward printed in Nova Scotia, in the fall of the same year, both editions aggregating 10,000 copies. At Bermuda Mr. Hallock edited the Royal Gazette for several weeks at the request of the queen's printer, Donald McFee Lee, Esq., who was prostrated with fever. Then he took steamer to Halifax, Nova Scotia, and resided in that province and New Brunswick some three years or more, contributing to the papers there, and editing at different times the St. John Courier, the Telegraph and the Humorist, the latter a small weekly satirical journal which he started in St. Jolnn. The Courier was the confederation organ of the Province of New Brunswick, and contributed much to the consummation of the Dominion, being prompted by Sir Samuel L. Tiley, Peter Mitchell., R. D. Wilmot, Esq., and other leading politicians who wrote for it. The Humorist, edited coincidentally by Mr. Hallock, and printed in the Courier office, was anti-confederation in politics. The year previously he had published in the Halifax Citizen a series of thirty-seven politico-satirical papers entitled "Joel Penman's Observations; or, the Provinces Through Yankee Spectacles," a very successful brochure, whose perspicacity subsequent events have almost verified to the letter, not only as respects political changes, but internal improvements and commercial relations.

That Mr. Hallock has capacity for other avocations than journalism is indicated by the fact that he established the first exchange and money office in New Brunswick, subsequently extending the business to Halifax, through a branch office, where he also became one-fourth owner in the shipping house of Wilkinson, Wood \& Co.* It was his accidental residence in Canada that has enabled him to gain much general information, which he was able to turn to such good account in his books and in the Forest and Stream. 
In 1891 the leading citizens of Northampton, Mass.y headed by the mayor; Editor C. 'M. Gere, Dr. J. M. Fay, et al., gave him a public dinner, at' which' thirty plates were laid, each course illustrating titles of books on natural, history and sport of which he was the author.

In June, 1866, Mr. Hallock's success in business, which was very considerable, coupled with his income from his interest in the Journal of Commerce, which he still held, and a one-fourth share of the large estate left by his father, who died a few months previous, induced him to give up business altogether, and he returned to Brooklyn, N. Y., after five years' absence, and purchased an attractive residence on Gates avenue. He then devoted his time to traveling and literary labor, appropriating several months in each year to visiting remote regions. For one year, during 1868, he was the financial editor of Harper's Weekly. In February, 1873, he became an incorporator and director of the Flushing and Queen's County Bank, New York, of which he was a large stockholder. In the spring of 1873 he printed his "Fishing Tourist," a work that has been much commended for its scope and accuracy, it being a complete guide to the principal salmon and trout districts of the United States and Canada. In August of the same year he commenced the publication of a sportsmen's weekly periodical known as the Forest and Stream, a 24-page journal, now widely circulated in all parts of the world. The object of this publication, as announced, was "to inculcate in men and women a love for natural objects, and.to cultivate a high moral tone in this department of literature." The result, it is needless to state, has been fully and worthily accomplished, and the founder of the paper finds his due of praise in thousands of homes where it is read every week. Few persons have a larger or more extended acquaintance among civilians and army and naval officers than Mr. Hallock had. Of war vessel salt water acquaintances he names one hundred and forty. St. Retao, for one, took him to Anticosti, of the St. Law rence.

As the compliment in a foreign paper (Die-Jagdzeitung, of Eilenburg, Prussia) indicates, "Hallock's works as a writer entitle him to a world-wide fame; but in America his services have been, in addition to all this, of a most substantial and business-like nature. He first formulated the general ideas on game protection, and pushed the same forward to the present excellent laws on that subject, a work of love that deserves the highest commendation, for it involved the difficult task of showing to a republican country the real difference between the aristocratic game laws of the olden times which were intended for the few'grand land owners, and the modern game laws, which as a part of our civilization protect and breed game for the reasonable good of all the people."

He was the prime mover and promoter of the International Association for the Protection of Game and Fish, comprising a membership of 250 of the leading sportsmen, naturalists and fish culturists of the country, with representatives in every state and territory of the United States and every province of Canada. The design was to formulate a common law book for the whole of America; but the impracticability of the measure would seem to have been demonstrated in later years, as no consummation has been reached. In testimony, however, of the appreciation of Mr. Hallock's endeavors, he has been elected honorary member 'of something like thirty-five sportsmen's clubs in various parts of the United States and Canada, besides some twenty additional historical societies, etc.

Mr. Hallock was also one of the incorporators of the Blooming Grove Park Association, in 1871, of which he was president and Fayette S. Giles first sècretary. This association owns 12,000 acres of territory in Pike County, Pa., which is appro- 
priated to the propagation of game and to hunting the same. It has 200 members and a large clubhouse and many annexes and cottages. In 1875 Hallock took after buffalo in the Indian Territory (Nation).

In 1876 Mr. Hallock published his "Camp Life in Florida;" in 1877 , his notable work, "The Sportsman Gazetteer,' 'a perfect compendium and book of instruction, which has run through seven editions, and received the encomiums of the press on both sides of the Atlantic; in 1878, "The American Club List and Glossary;" in 1880, "The Dog Fancier's Directory and Medical Guide;" in 1886, "Our New Alaska;" in 1890, "The Salmon Fisher," besides four volumes of a different class, including college and family genealogies. Besides book-making he has contributed constantly to the daily and weekly press in and out of New York, gathered from commercial, mining and railway sources, by whose influence he had worked. Occasionally he has dipped into poetry, having written some fair poems, humorous and sentimental, quite a few of which have been printed as far back as 1855 .

When in college Mr. Hallock was elected a member of the D. K. E. Fraternity, and has since filled the honorary positions of secretary and vice-president of the New York and Washington (D. C.) Alumni Associations. He has held no public offices.

In January, 1880, he soid his interest in the Forest and Stream to Dr. George Bird Grinnell, a nephew of Hon. Levi P. Morton, and retired from its management, greatly to the regret of his constituency. In April following, however, he was induced to accept a one-fourth interest in the Sea World and Fishing Gazette, a weekly journal devoted to angling and the commercial fisheries, published in New York, but his business interests in the far west prevented his devoting much attention to it, and he may be said to have then practically abandoned the field of active journalistic labor.

One of the most signal projects which he has yet undertaken was instituted in 1879. It was the establishment of a Farm Colony for Sportsmen, in the extreme northwestern county of Minnesota, adjoining the Manitoba line. There, in the midst of the finest game and grain-producing region in America, he gathered around him many old friends of the rod and gun, and erected a large hotel at a cost of $\$ 12,000$, which he hoped would become a stated resort for sportsmen during the summer and autumn seasons. His location was on the St. Paul, Minneapolis \& Manitoba Railroad, and was called Hallock. It is the county seat of a rapidly developing section. He attempted to place the enterprise in the hands of a stock company because Jim Hill had frozen his tourists out. His scheme included a sylvan park of primitive forest, beautified by a winding river, where sportsmen might locate summer cottages and escape from periodical heated terms, but it failed. Carnegie would not assist. In 1892, Christmas night, the hotel burned up without insurance.

Altogether Mr. Hallock's roving life, tastes and habits of close observation have especially qualified him for just such duties as he has thus far imposed upon himself; and although desultory and erratic, they have not been. without benefits and usefulness to mankind. On one of his long vacations he attached himself for seven weeks to a squad of mounted revenue police, under Major Wagner, operating in the mountains of the Blue Ridge, to suppress the manufacture of illicit whisky, and a sketch of his adventure, as well as of the contraband traffic, together with valuable statistical information, was printed in the New York Herald in March, 1878.

One peculiarity of the Hallock family is its longevity, which is possibly scarcely exceeded. In $18 \pi 7$ this was referred to by the New York Times, and in December, 1879, the Brooklyn Eagle printed a list of fifty-four Hallocks whose average ages 
were $821 / 2$ years, and of this number twelve were upwards of 90 years-one, the grandfather of Major-General Henry Wagner Halleck, having reached the extreme age of 103 years. At the later date of January, 1911; twenty are reported to be living above 95 .

Charles Hallock's grandfather was Rev. Moses Hallock, of Plainfield, Mass., and his great uncle, the Hon. Jeremiah Hallock, of Steubenville, Ohio. His grandfather, Moses, while he had pastoral charge of the church in Plainfield, Mass., taught a classical school in which 304 students were fitted for college. His father, Gerard Hallock, a graduate of Williams College, broke ground for the founding of Amherst College while principal of the Amherst Academy.

Charles Hallock was married in New York on September 10, 1855, and had sons born in 1856,1860 and 1861 , all of whom are dead. His wife's two Wardell uncles founded the I. O. O. F. (Odd Fellows) in 1819.

In 1900 Prof. Elliott Coues, of the Smithsonian Institution, wrote: "Charles Hallock, A. M., while not strictly a scientist, has been a member of one or more of the scientific societies of Washington since their organization, and has filled a unique and useful position for fifty years as a close observer and discriminating collector in the field of natural history. Prof. G. Brown Goode, of the National Museum, once wrote: 'No man can help us like Charles Hallock.' No geographical division of North America, marginal or intermediate, from the subarctic regions of Alaska and Labrador to the Carribbean Seas, has escaped his attention, while his sketches of travel which have appeared in the magazines and leading journals of the United States and Canada, together with the Forest and Stream, which he established in 1873 , and his numerous books, have given him an enviable prominence among tourists, sportsmen and savants, not often acquired by specialists of his ilk. His 'Fishing Tourist,' published by the Harpers in 1873, was the record of twenty-five years of wandering through the wilderness areas of the United States and British provinces, and as long ago as 1878 , George Dawson, the eminent editor of the Albany Journal, and himself an angler of renown, wrote: 'Charles Hallock has written more and more wisely than any of his contemporaries.'

"As an ichthologist, Mr. Hallock led the van up to the date of his 'Sportsmen's Gazetteer,' a 900-page volume, which appeared in $18 \pi 7$, that portion of it which treated of the edible game fishes of America, their synonyms and classification, being in advance of all other works, and was so quoted by Prof. Theo. Gill, who assisted the author very materially in his description of the Pacific coast fishes thercin enumerated.

"The Florida peninsula had early engaged Mr. Hallock's attention, and in 1874-5 he fitted out the Ober and Al Fresco (Dr. C. J. Kenworthy) expeditions to the Seminole country and the west coast, and when his 'Camp Life in Florida' appeared, in 1876, the citizens of Florida privately, and through the press and public meetings, acknowledged to the author his substantial services rendered to the state, so little had been previously written of its geography and resources. In the same way Mr. Hallock received the thanks of Minnesota in 1858 for his services to that state. And in 1859 he opened up the Aroostook forest region of Maine to agriculture, through a summer of investigation, and a series of letters to the New York Journal of Commerce, of which he was then junior editor. The summer of 1860 was devoted to an exploration of Labrador, in company with myself, and from 1863 to 1866 to the Maritime provinces, including Sable Island, the Magdalens and Anticosti. Mr. Hallock was one of the pioneer prospectors among the Ontario gold fields. The net objective results of these and many other similar adventures 
appear in the Hallock collection, aggregating a value of several thousand dollars, which he donated to the Long Island Historical Society, of Brooklyn, in 1883. In $1885 \mathrm{Mr}$. Hallock went out to Alaska and wrote up its resources and commercial possibilities in a work entitled, 'Our New Alaska,' with the subtitle of 'The Seward Purchase Vindicated,' every word of which has proved intelligently prophetic and true.

"Not to be prolix in review of a most interesting life history, it may be said that four signal achievements' of note accentuate Mr. Hallock's record. First, the Forest and Stream, which has had the effect to elevate the tone and status of sport, to disparage whatever was evil in popular pastimes, and to make the new woman possible. Second, his scheme to $\operatorname{sect}^{+1}$ co-operative legislation for the protection of game, and to formulate a code of laws based upon the distribution of species, and uniform, as far as practicable, in their application to areas having the same climate and fauna, success to be accomplished through the agency of an international association for the protection of game, which he organized in 1874. Third, the incorporation of the Blooming Grove Park Association, in 1871, Mr. Hallock being its first secretary, and a most active promoter of the finest existing game preserve on the continent. Fourth, the publication of the 'Sportsmen's Gazetteer,' which gave to the pupils he had traired a passe-partout to health, and a handbook by which they might stalk the continent of North America, and of which the London Field asserted that 'a more complete and comprehensive work had probably never been published by any sportsman,' a gracious tribute bestowed in the face of the. fact that its own chief editor, Mr. Walsh ('Stonehenge') had already published in England an 'Encyclopedia of Rural Sports,' and other standard sporting books.

"Briefly, if Mr. Hallock's claim to the gratitude and good will of American sportsmen rested solely upon his labors in behalf of the preservation and propagation of game and fish, he would stand deservedly high in the cstimation of those members of the guild who appreciate true sportsmanship, and believe in giving honor to whom honor is due. In line with this thought it should be mentioned that away up in the northwest corner of Minnesota, on the edge of what was once the great Roseau game region, there is a town of 1,200 people bearing his name (Hallock), which is the county seat of Kittson County, the most progressive municipality in the whole Red River Valley. He is the father of this town."

The American Field, in 1888, printed the following, according to Dr. A. J. Woodcock, of Byron, Ill.: "Probably there are few sportsmen who are known so widely by name, and so little by direct personal acquaintance, as Mr. Charles Hallock. His books and writings have given him prominence in the field of natural history and sport, and have always been accepted as authoritative in a certain sense, because he speaks only of what he has observed and experienced, not by hearsay."

Although socially inclined, Mr. Hallock is more apt to be found in some remote and unvisited region than at the trap or butts. He is as nomadic as an Arab. Although interrupted by spasms of business activity and speculative venture, all the aims of his life seem to have been subordinated to a love of perpetual motion. Like the cork leg in the song, he is always wound up and going.

Born in affluence, with abundant opportunity for travel, Mr. Hallock has extended his wanderings with rod and gun to riearly every geographical division of the continent. Many of his explorations have been by canoe and saddle, in advance of settlement and wagon roads. Since $1880 \mathrm{Mr}$. Hallock has been occupied to some extent with real.estate operations in Minnesota, although his winters are spent in 
Washington, at the National Capitol, in close communion with the Smithsonian Institution and kindred societies, three of which include hin as an active member.

$\mathrm{He}$ is as good an all-around editor as he is sportsman. In $1866 \mathrm{Kendall}$, of the New Orleans. Picayune, invited him to that paper at a salary of five thousand dollars. Kendall said he wanted a man "who could jump.in anywhere." *

Referring to Charles Hallock's descriptive powers as'a writer, no tribute could be more convincing than the following lines spontaneously addressed in the year 1901 to the author of "The Bison's Paradise," by Dr. Robert Bell, F. R. S., of the Canadian Geological Survey, who is probably the best authority in the world: "Ýour description of Northern Minnesota would be hard to beat. To the mind of one who has seen it, as I have, and the same in the Red River Valley in Manitoba, it is a perfect picture, and makes you imagine you are there again. 'Yout can almost feel the wind waving the tall grass and hear the cries of the various kinds of birds. You must have a good knowledge of botany, as well as natural history, to be able to describe the flora of that region so accurately. The whole is a vivid picture of the Red River Valley as I saw it thirty-five years ago. And at the same time that it is so eloquently expressed it contains no mistakes." The article was published in the Minneapolis Journal first, and afterwards in the Springfield (Mass.) Republican.

The following bill, one of the most unique ever rendered to civilized man, was presented to the state of Minnesota by Mr. Hallock to cover the installation expenses of his frontier exhibit at the New Orleans Cotton Exposition, in 1884-5:

New Oreans, La., November 10, 1884.

To Samuel E. Adams, Treasurer State Board Collective Exhibits, New Orleans Exposition: To-

1 birch wigwam complete.

1 Indian baby cradle.

4 sets squaw frocks and shawls.

6 lay figures.

2 rush mats.

1 birch maple-sugar mokuk.

1 birch maple-sugar mould.

2 mokuks killikinnik.

1 bundle red willow sticks.

1 old toboggan.

1 leather cariole.

1 good canoe.

1 old canoe.

1 fish spear.

1 bear skin.

4 dozen cat-tails.

1 dry hide.

2 pitch pine torches.

3 Eskimo (huskies) dogs at $\$ 15$ each.

Paid for killing dogs, -

Taxidermist work on same.

32 large and small photos of scenery, and portraits.

3 large maps of Minnesota and Manitoba, sundry properties.

3 paddles.

1 cedar torch.

1 ball pitch.

1 bag seed rice.

3 sets shaganappi dog harness.

1 Red River cart.

1 red toque.

2 sets shaganappi ox harness.

1 pair snowshoes.

1 capote.

1 pair beaded flannel leggings.

4 pair moccasins.

1 felt hat.

2 nor'west sashes.

1 pair corduroys.

2 store wigs.

1 pair leather (buck) breeches.

1 bundle horsehair for 6 wigs.

Received payment, CHarLes Hallock.

(Mokuk is a bark basket without handle. Moulds are bark cornucopias, which 
are filled with melted maple sugar while inverted, and are carried by a buckskin thong, which is passed through the point of the cornucopia before it is filled, the end being knotted so that it will not slip through. When hard the sugar holds it immovably. Killikinnik is the inner bark of the red willow, which is mixed with tobacco for smoking. Shaganappi is untanned hide.)

This exhibit was the prinitive forerunner of the many better like shows which have been presented at sportsmen's expositions held in Boston, New York. Chicago and elsewhere during the subsequent twenty-five years.

It is an interesting fact, attesting $\mathrm{Mr}$. Hallock's mechanical ingenuity, versatility and general knowledge of backwoods craft and aboriginal belongings, gathered during his forty years' previous wanderings, that he set up this entire exhibit quite unaided, carpenter work and all. He set up his tepees, costumed his lay figures, painted their faces and wigged their heads, made his imitation snow and water for winter and summer seasons, laid out his wild rice paddock, fitted up his camp, posed his groups, rigged his dog teams, etc. One group represented squaws in canoe beating out wild rice in situ; another two Indians in canoe spearing fish. There was a home camp with squaws and papoose in standing cradle; a Canadian traveling cariole with fur-clad occupant and driver behind on snowshoes; a tepee with its furniture, fire and primitive cooking apparatus; a Red River cart from Northwestern Minnesota, peculiar to the fur trade half a century ago. Of the quality of this primitive exhibit, it may be remarked of the figures in the fishing canoe that they were so close to life that they engaged the discussion of a Mississippi "cracker" and his wife, who finally settled the question by prodding the spearman with the point of a cotton umbrella to see if the figure was real. As a droll sequence to this episode they afterward tested the living group of the dignified Gall, wife and son (who formed part of the Dakota exhibit), in the same way, with a recklessness which would have cost them their hair had the contretemps occurred on their native prairie a few years sooner.

Associated with Mr. Hallock's exhibit was a reproduction of Minnehaha Falls in real water, about half size, by Prof. N. H. Winchell, of the Minnesota University. The whole was viewed with great interest, and elicited a full meed of praise from the newspapers of the period.

\section{The Dean of American Sportsmen.}

"Honor to whom honor is due" should be the motto of every American citizen, and it is gratifying to note that the devotees of gun and rod, especially those showing keenest interest in the literature of out-of-door sports, show proper appreciation of services rendered by that distinguished gentleman now recognized as the Dean of American sportsmen. A Washington correspondent, writing to the editor of the Sportsmen's Review on this subject, makes the following appreciative comments:

"There is a well-preserved old gentleman, seventy-five or seventy-six years of age, who is frequently seen in the grounds of the Smithsonian Institution at Washington during the cooler months of the year, occasionally entering the offices of the various departments, and any one whose attention is attracted to his presence will observe that he is everywhere received with a familiar courtesy which betokens respect tempered with personal regard. Whenever he enters he seems to have a special errand, though he invariably deprecates intrusion upon.busy men in busy hours. When his mission is accomplished in this or that department, and he moves to take leave, he is almost invariably escorted to the door by the chief of the bureau. The oldest officials seem to know him best, those of middle age are less demonstra- 
tive, though all recognize him as the dean of the Smithsonian, and he is generally so regarded. Indeed, the fact is historical that his connection with this institution dates as far back as the fall of 1860 , at which time Prof. Spencer F. Baird, who was then chief fish commissioner of the United States, did him the honor to look him up at his residence in Brooklyn upon his return from his collection trip in Labrador in company with Prof. Elliott Coues, who at that time had just made his maiden trip in the interest of ornithology.

"Ever since that time Mr. Hallock has been doing gratuitous service for such departments as his wide field experience would enable him to aid, more especially in zoology, geology, geography, ichthyology, entomology, biology, enthropology, forestry and agriculture, and also in the Indian office and weather bureau. At one time, when Professors Harkness and Eastman were in charge of the naval observatory, he was a frequent visitor there.

"The other day, by request of Cyrus Adler, librarian of the Smithsonian, he opened out correspondence with Professors Henry and Baird, dating to 1867, and embodying transactions which will find permanent place in the comprehensive biographies of those distinguished functionaries which are now being prepared under the personal direction of their daughters, Miss Lucy Baird and Miss Mary Henry. The chief of these papers related to the establishment of the Central Park Zoo in New York, and the installation of its first superintendent under the supervision of Andrew V. Green and Salem H. Wales, Mr. Hallock selecting the party. There was also a letter written by Marshall McDonald to Mr. Hallock in 1873, requesting his influence in establishing his fishway, which he had just perfected. This gentleman afterward succeeded Professor Bird as fish commissioner. Mr. Hallock had that year started his popular weekly journal, which was at once employed as a medium of scientific communication by Dr. Theo. Gill, Elliott Coues, H. V. Hayden and other notables working under the auspices of the Smithsonian, many of whom, like General Brisbane, the two Schoifields, Captain Bendire, Colonel Albert Mallory, and others, held high official rank in the army.

"Mr. Hallock had many distinguished correspondents in Canada, such as Dr. Robert Bell, H. G. Vennor, William H. Venning, Moses Perley and other scientists. He had the unlimited confidence of them all, and this acquaintance throughout the continent-nearly all of which had been traversed by Mr. Hallock himself during the twenty-five years previous to $1873-$ gave him a wide and powerful influence.

"And this is the reason why this gentleman is honored in his declining years as he rambles through the grounds of the Smithsonian, which he has been so long familiar with. We is well preserved physically, has never had serious illness, and is likely to line up with his ancestors, who have been proverbially long lived. $\mathrm{Mr}$. Hallock is a winter resident of Washington, but he passes his summers in Northwestern Massachusetts, near a little village naned Plainfield, in the Hampshire Hills, where repose the relics of five generations, and where the brook trout bite freely in the spring. He is there at the present time."-SPORTSMEN's REviEw. 


\section{CHAPTER II. \\ ANGLING UAYS AND ANGLING WRITERS. \\ "As life runs on the road grows strange \\ With faces new; and near the end \\ The milestone into headstones change, Neath everyone a friend."}

YES, it's up to me! I have traveled wide, met many people, led a checkered life, and grown old; and because I have passed seven years beyond the Scripture limit of three-score and ten, and so survived the majority of globe-trotters who were contemporaries of my youth and young manhood, I have been deputed to act the role of "Old Mortality," and repeat his kindly offices by scraping off the moss which has overgrown their personal records and their memories. So here I am again, as the clown said when he tumbled into the ring; and in accordance with the stereotyped fashion of campfire narration, I will proceed to knock the ashes from my pipe and summon the res gestae of the departed from out of the nimbus which enfolds the brain. What will be mere gossip to the adolescents $v-i l l$ be hard-pan reminiscence to the old and superannuated.

And this "reminds me!"

But first let me say a word for myself, how I came to meet up with these sturdy and weatherbeaten men at arms, who, like Romulus and Remus, were suckled on the lupine milk of tough experiences; who have tracked the sequestered parts of earth: and followed the blazes through the woods and over the ledges; and the tide-rips over the seas. It will carry us back quite a little to those days when residents of New York City got all their water from wooden pumps at the street corners, when pigs rooted the gutters, and the night watch wore black leather capes and sou'westers in rainy weather, carried brass stars on their breasts, and called off the small hours with "All's well!"

I was born a little above Canal street, about the time when it was crossed by a bridge, but I never fished the Collect Pond, where the "Tombs" stand now, nor shot snipe on the Lispenard Meadows, but my nurse used to wheel me along the footpath that meandered diagonally across the Washington Parade Ground to Sixth avenue and Thirteenth street, and I grew apace on the prosperity which preceded the great fire of 1835 and the panic of 1837 .

With the rake-off from that period of inflation, my thrifty father built him a replica of Kenilworth Castle, with tower and battlements and retaining wall on a bluff by the seaside at New Haven, Conn., and there I was nurtured and grew to my teens; clams at low water and ducks at high tide, dapping in the full of the moon along the sedge where the incoming waves lapped the musselbeds which lined the curve of the beach. In that school of technology I learned to build a correct fire, and cook shell-fish on iron hoops, as practiced at Coney Island in the old days when it was only a waste of sand dunes and salt grass, and Gil Davis was "governor." What would the old man think of the transformation now? What would John I. Snedicor, who ran the Oceanic, and old man Wykoff say? Wykoff had the only shanty on the island. There were conies in those days, and striped bass run up the Coney Creek. 
One learns his salt water lessons early who is reared beside the bright waves of Long Island Sound. Given a good centerboard lapstreak boat and unrestricted personal liberty, in off hours of boyhood, and there is no better kindergarten for the angler than its broad expanse and the tideways of its indented shores; and inasmuch as the greater part of my tuition was acquired at Brooks \& Thatcher's boathonse with the hopeful son of the senior partner as my inseparable companion-unless I chanced to take up with Charles F. Hotchkiss or George H. Townsend, of East Haven, who were much older men-we two, John and I, soon learned the caprices of that changeful Mediterranean and all its belongings, and how to shape the "Teazer's" course accordingly. And John is living yet-at Minnetonka. We knew every rock, ledge and reef, and every spit, spar-buoy and spindle from Charles Island to New London.

We made the acquaintance of the light-keepers at Marvin's Point and Faulkner's Island, and were solid with the hotel-keepers at Branford Point, Double Beach, Stony Creek, Thimble Islands, and Savin Rock. Sam Upson, Malachi

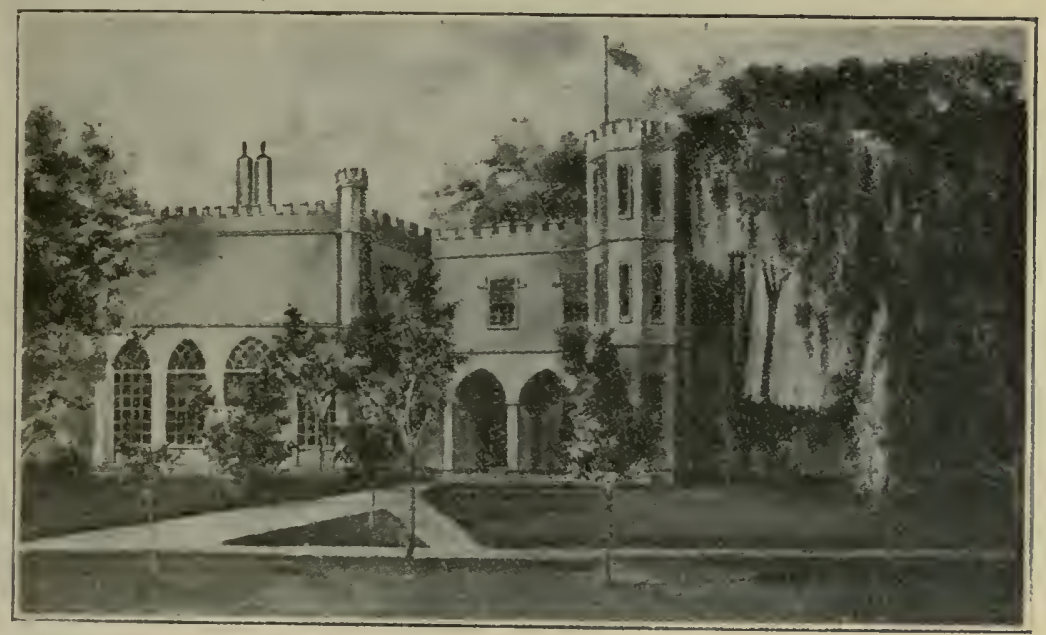

HALLOCK CASTT.E.

King, and the rest. Once on a July day we made for the land in time to avoid a thunder. squall which was coming up in a threatening manner. There were quite a few sailing craft in the offing. Being less prudent than we, several were capsized, and the "Teazer" ran out and picked three nen, who were strangers, off the bottom of a yacht that had turned turtle. Some fifteen years afterwards I happened to be in Savannah, Ga., and was telling the incident to Fred Sims, of the Morning News, when he exclaimed, "I was one of those three men!"

Charles F. Hotchkiss was a forty-niner, and I saw him start that year in the brig, Gen. Armstrong, from the end of The Pier at New Haven, for the long voyage around Cape Horn to San Francisco. There he set up in a tent one of the hob-nailed iron safes used in those days, and that was the first bank of deposit in California. George Townsend was a man of wealth and owned a fine yacht. Brooks \& Thatcher built for the Undine Club of Yale College, in 1851, 
the first college racing boat in this country. Everybody who has been to Minnetonka Lake, in Minnesota, within the past twenty-five years, knows of Capt. Brooks, a quaint man of rare intelligence, of the Walt Whitman type, with flaxen hair which even now hangs in wavy yellow masses over his shoulders. That's my mate of the callow days, now in his eightieth year! He went to college, went to sea, went to ranching in Texas, went to Africa and the South Sea Islands, and came back tatooed from head to foot; an ivy wreath of India ink around his neck, a grapevine twined around one leg and a black snake around the other; coats-of-arms on his breasts; female figures on his back where he cannot see them; devices on his arms, and only his face clear of sepia. Crowds used to gather at the lakeside to see him give swimming lessons to both sexes and admire his epidermic embroidery, for he wore merely a "trunk" on the occasion.

There was good quail and rabbit shooting in the hills around New Haven in the forties, and I managed to put up a good many birds without a dog. At ten years of age I potted three quail out of a covey in a ryefield near ny father's house on Oyster Point. This was my maiden shot. Ike Bush was an occasional companion. We had been hunting back of East Rock one day without starting a feather, when just before we reached the brow of the cliff, I raised my hand in admiration of the marvelous harbor panorama in front, when a bevy of twenty or more birds whirred up from under our very feet! Ike went into ecstasies over the scenery, and I collapsed. He went into business at Norfolk, Va., before the war, served gallantly for four years in the Confederate army, and died in Suffolk four years ago at the age of seventy-three.

During those boyhood years we attended Uncle Amos Smith's school, near by a dingie where there was a noble hardhack grove, and a clear spring with watercresses and frogs. It fed a salt water creek, where we dipped killies for fishbait; and there we used to run bogs in the summer and ice cakes in winter after a tidal overflow, becoming so expert as seldom to make a misstep. This practice made us quick of eye and light of foot, and proved of great service in after years, especially in river work and handling canoes. On one occasion I remember in the Adirondack, in 1871, old Steve Turner, my guide (he was sixty years old then), broke an oar in the Bog River Rapids above Percefield Falls. The trout were among the rocks and we had been picking them out, though the current was too swift to save them all. The falls were just a little below us and 28 feet high, and it would be a bad smash for the boat, and something worse than wet feet for us, to go over. As the crippled boat swung around with the current and swept down stream near to a convenient flat rock. I stepped out lightly, grabbed the boat by the gunwale amidships, and held her until Uncle Steve could clamber out and make her fast. It was not a great trick to do, but let me tell you that a babe in the woods in the same pinch would have got rattled, missed the rock, and trouble would have followed. With a convenient gimlet and two yards of wire I had the oar spliced in a jiffy, and we pulled up happily out of the drink. It was my habit always then and afterwards to carry a kit of small tools with me, which helped me and others less provident out of many a serious diffculty in camp or en voyage, wherever and everywhere about the continent.

My youthful shooting proclivities gave my matter-of-fact father much trouble, but he was sensible enough to humor my bent. So I was taken out of school at twelve years of age and sent to my uncle's farm in the Hampshire hills of Northwestern Massachusetts for two years and a half, where I became initiated in 
forestry and the ways of the woods, and learned the tricks and manners of farm animals. I could manage the horses and cows and sheep all right, because I gained their confidence. The same bay mare who slung my uncle across the stable with her teeth would let me tangle myself up with her legs and hoist with my back against her belly while I was grooming her; and the "little cow" allowed me to shoot off my gun between her horns, standing in front of her, and not flinch.

Later I was taken from Hopkins' Grammar School at New Haven and sent to Framington, Conn., where I could have a boat and gun and shoot muskrats on the overflows of the river. From Yale College, which was too artificial for my taste, I went to Amherst, where I could range Mt. Holyoke and Mt. Tom and pick up rocks and minerals for my cabinets. And so it went until I graduated, married, and went into business.' I was of age.

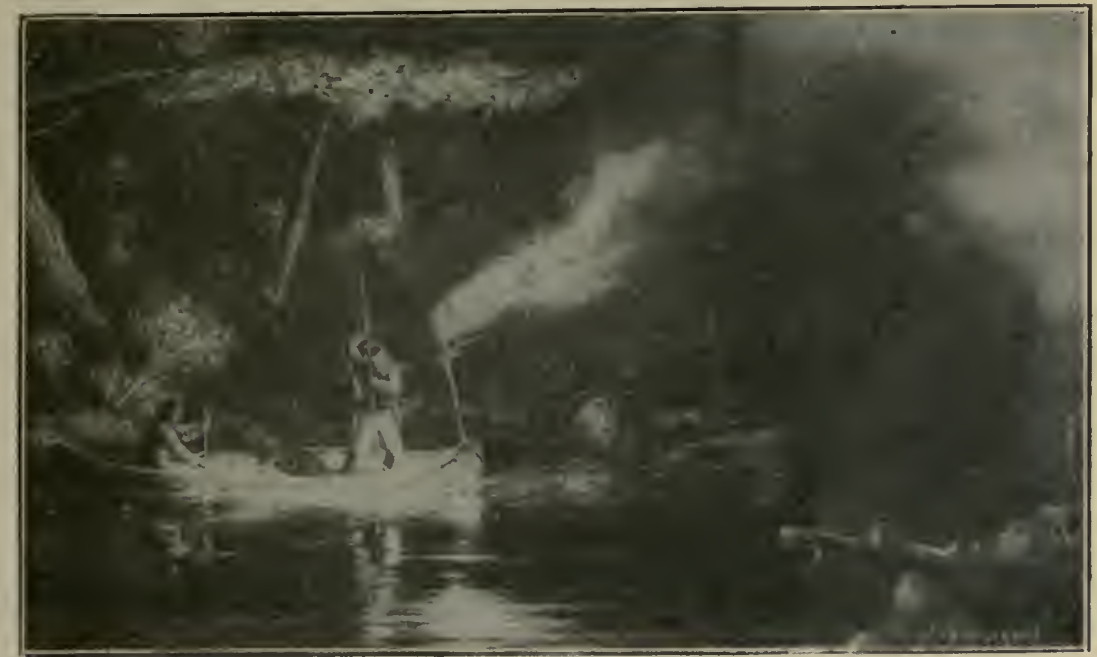

SPE.IRING S.ILMON ON THE RESTIGOUCHE.

Mr. Hallock fished for salmon on this river half a century ago.

But these responsibilities hardly checked my vagabond proclivities. I commenced to go west of the Mississippi early in the fifties, and there I first heard of Kit Carson, Fremont and Jesse, Pierre Choteau, Jim Beckworth, Jim Bridges, Bill Bent, and Charley Bent, his half-breed son. I read up Ruxton's "Life in the Far West" in 1846 and W. C. Prime's "Owl Creek Cabin Letters," and "Old House by the River," Lanman's "Wilds of America," and Rev. John Todd's "Long Lake" and Chas. W. Webber's "Romance of Natural History" (in Texas), and Col. Emory's Military Reconnoissance from Fort Leavenworth to San Diego, Cal., during the Mexican War. All these were contemporary writings, and it was not long before my old schoolday companion, Bob Stiles, and I came to be introduced to some of the real characters. Bob was the same Maj. Robert A. Stiles, of Richmond, Va., whose army reminiscences of the Confederate War, entitled "Four Years with Marse Robert" (Lee) were published in 1903, and who died two years later after a remarkable life of adventure and hair-breadth escapes. 
Bob Stiles obtained leave for us to join Charley Bent's freighting outfit at Westport, Missouri (now Independence), on condition that we would obey orders and feed fair, because we were going through the Indian country, and sonve of the reds were bad. There were some seventy wagons in the train, and a personnel of perhaps 120 men, of whom some forty were mounted as a horse guardquite a formidable body. We were bound for Bent's Fort, on the upper Arkansas (now the town of Williams), and were not out many days before we met up with about 3,000 Comanches and Kiowas-men, women and children, who had been waiting for weeks at the Great Bend of the Arkansas River for annuities from a tardy Indian agent, and were a-heap mad. I wrote up the story of that lively adventure in the October issue of Harper's Magazine for 185i; so I need not amplify here, except to say that to the long category of "Indians I have met" we added the names of Yellow Bear, a friendly Arapaho, who was with the Bent outfit, and Chief Shaved Head, of the Comanches, who came near having his windpipe cut with a cheese knife in Bent's hands, when some of his mounted warriors came charging down on us too near to be pleasant. The old fellow, you see, had headed a charge of his warriors the day before, and his pony being tough-bitted, carried him into our lines without his consent. He proved a valuable hostage thereafter, and perhaps saved the day for us. Really, we had a running fight of skirmishing, tactics and maneuvers for twenty miles, which lasted four days.

The experience, however, did not feaze me, and it was not many months before I was on the Red River Trail, in Northern Minnesota, with George F. Brott's party to open navigation between the headwaters of the Minnesota River and the Red River of the North. That was in 1858, the first year of statehood, and five years before the famous Sioux massacre. This was many years before the "Fishing Tourist" (1873) and "Sportsman's Gazetteer" (1877) brought the angling literature of America to its climax, and was so attested by Baird, Gill and Jordan at the time.

How comprehensive and aptly Mr. Roosevelt's history has been presented in Libliography may be ascertained by reference to the columns of the London Field (three papers) for June and July, 1887, under the title of "Angling Literature cf America," above given. The compiler, in his review of the period indicated, submits to reviewers that "nothing like a comprehensive manual of angling was published until 1864, when Thad. Norris' 'American Angler's Book' and Robert B. Roosevelt's 'Game Fish of the North' both came out."

That was during the year of the first lease of a Canadian salmon river, the Nepisiguit. Roosevelt's book made especial reference to that famous stream in its chapter on salmon fishing, itself a new revelation to the fraternity of fishermen. How to fish for salmon, the implements to be used, and a description of the sport, had never been presented before. The volume was a godsend to anglers, for it included the technology of angling, fly-fishing, tackle-making, entomology, fish culture, camping out, etc. It described new devices, new methods, and new fields of sport which had come into the purview during the sixteen years that had intervened since the enterprising J. J. Brown had prepared his "American Anglers' Guide" (1849). Moreover, it introduced to notice new species of fishes not previously regarded for sport and identified others which had been in doubt. The whole subject was in chaos at that time, scientifically considered. Experts had not even quite determined whether a brook trout and a samlet (parr) were 
the same, or that brook trout were not in fact immature salmon. The scientific world has moved since them.

In 1865, the year following his first production, Mr.. Roosevelt put out a supplementary book, entitled "Superior Fishing," relating chiefly to the fishes of the Great Lakes. These two books, as well as my "Fishing Tourist" and Prime's "I Go a-Fishing" (1873) were all published by the Harper Brothers.

Not only must Mr. Roosevelt Le recognized as a well-informed author of undoubted accuracy and reliability. but he was foremost with Agassiz, Baird, Theodatus Garlick, Ainsworth, Samuels, Prime, Mather. Sage, Seth Green, Slack, Frider, Norris, Royal Phelps, and other ichthyologists in the promotion of fish culture and preservation of fish. He was for many years, and up to the time of his death, president of the New York City Association for the Preservation! of Came and Fish, and wrote many articles on angling and kindred subjects in tho

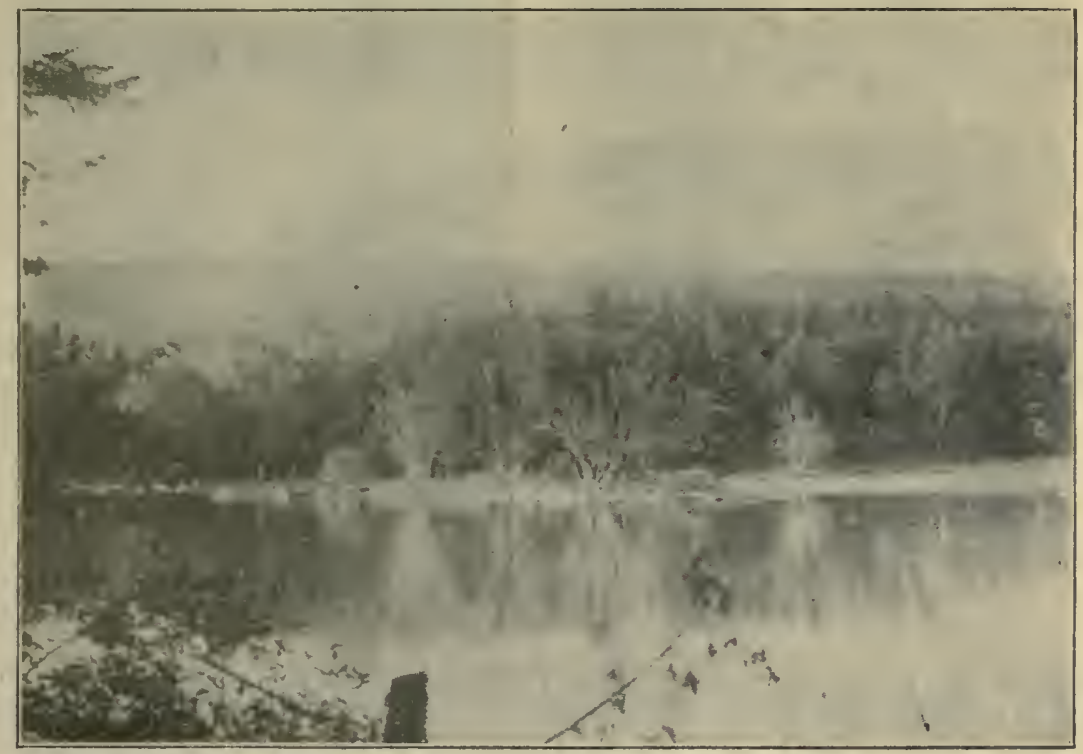

MIT. KATAHDIN FROM NEAR AIBOL C.IRRY. Visited by Mr. Charles Ilallock in 1859.

Citizen, which he published in $1856-5 \pi$. Verily, he is entitled to a leading place in history, and let the fraternity of anglers freely accord it. Honor to whom honor is due.

As to Norris: Forty-six years have passed since the first edition of Uncle Thad. Norris' renarkable book appeared, and of all the cognate emanations which have subsequently been written, few have been able to add or subtract anything to materially affect the integrity of the work or make themselves of better wortl. I am making no reference, of course, to the transcendent works of the purely: scientific field, in which the scale system, the lateral line, and the hyoid bone play so important a part. The "American Angler's Book" is today by long odds the best home book extant upon the broad subjects of which it treats, and this conceded precedence is made obvious by the fact that it is still in print, and that 
edition after edition has been consecutively made profitable to the publisher. It is purely an American book for American anglers. There is no "English" in it. There is as much difference between the habitats and habits of the fishes of the two continents as there should be between the methods and appliances of fishing for the same, and the angler who would substitute one for the other would be as likely, if he were a shooter, to hunt for jacksnipe with a rifle in a chapparal.

The field of indigenous angling literature was fallow when Norris entered it. Lanman, Herbert and Bethune had worked the ground over, and so had Harry

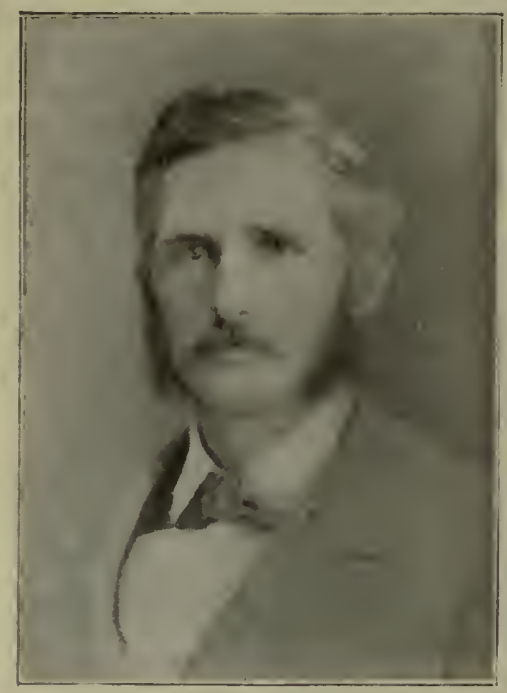

DOMINE OLMSTEAD,

Grammar School, New Itaven, 184i.

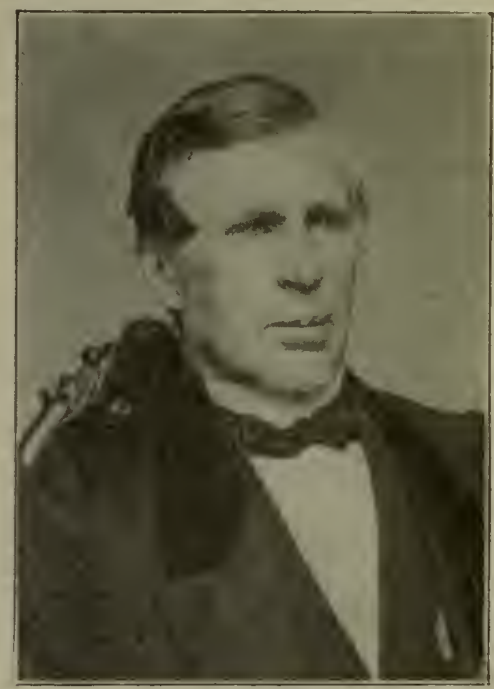

MIR. CHAS. F. HOTCHKISS, A New Haven Forty-niner.

Venning, a Canadian, now in his eigthy-eighth ycar, who wrote with a masterful pen of the haunts of trout, salmon and land-locked salmon years before. Laninan's volumes, entitled "The Wilds of North America," which covered almost the entire surveyed domain of this continent, and much that was primeval, wcre printed in 1845; but to the youth of this country his utterances were as dead languages then, and never so much prized as now; when long time out of print. Norris' book came opportunely, and it has continued opportune ever since. Latterday aspirants have written books of positive merit, Louis Rhead in lead, but the ichthyologists have very properly, doubtless, first read up Thad. Norris. In order to do full justice to his subject he would hardly be wise to modify or change. 


\section{CHAPTER III.}

FISHING JAUNTS AND ANGLING ASSOC1ATES.

My preceding chapter, opening this memoir, is not so much a record of my personal rambles about wild regions and unsettled tracts during the middle of the past century, as a recollection of sportsmen of an older generation than I whom I chanced to meet up with from year to year. Reminiscences tossed out at random bring me up to 1859 , when I cast my first salmon fly in the deep pool below Aroostook Falls, in Maine; and the rod and reel I used there is now among the relics of the "Tuna Club" at Catalina Island, in California, where the chief of all live sea anglers, Prof. Charles F. Holder, is its president. It was bought at Conroy's, in New York, opposite the Pritchard Brothers tackle shop, in Fulton street, in 1858. That summer I took in the Grand Stream Lakes, where Dr. George W. Bethune had his camp at the outlet, with a big party from Houlton, and afterwards fished at St. Croix River and Sebago Lake for landlocked salmon; visited Fort Fairfield, of the historic Aroostook War, Fort Kent, and the French settlement along the Madawaska for sixty miles to St. John River. In 1860 I went to Labrador with Prof. Elliott Coues, F. S. Knowlton and George Lunt, of Washington Smithsonian; caught sea trout and river trout all the way up the coast from Belle Isle Strait to the Eskimo Bay, latitude $55^{\circ}$, and to the Rigolet Post, where salmon were plenty and were netted by the Eskimos for the Hudson Bay Company.

A broad vista opens wide during the lull before the war, about the year 1860, fairly crowded with the names of great men who fished (not great because they fished!) ; and their deeds-are they not written in many books of chronicles?

During the Civil War rifles took the place of shotguns, and slaughter in the field at large was done to order. Meanwhile sporting papers of the day were suspended, with the single exception of Porter's (Wilkes') Spirit of the Times. After reserving the first three years to the struggle for the Union, I applied the next three years to a complete tour of the Maritime Provinces of Canada, Prince Edward Island, Cape Breton and Quebec to a collection of trophies of all varieties of fauna for the museums from numerous wilds and streams, the results of which endeavor appeared duly in my "Fishing Tourist," which was printed by Robert Rutter in 1872 and issued in the following spring. This diligent old gentleman is alive still, and working uptown in New York at the age of eighty years plus.

The dilettante gunning class, with their hunting dogs, had not yet come into view, because the era of deadly machine guns had not arrived, and gentlemen who hunted them were just anglers, who went to secluded waters, and shot birds and animals only for the camp. Had I the gifted pen of Levant F. Brown, who finds beauty in every wild, and makes the woods and waters fairly gleam in his descriptions, eloquent with poetry and song, so that even the birds break out responsively to his call, I would braid laurels and eglantine for the heroes whom it is my privilege to name as sportsmen, and whom $I$ have personally known during that period of my lifetime which I am about to survey. Men like Lanman, Thoreau, Burroughs, Venning, W. M. Brackett, E. A. Samuels, William C. Prime, 
Reverend John Todd, and a host innunierable, are in the ranks, all aged and venerable; and who of them all shall take precedence? Brackett and Venning still live at eighty-seven and eighty-eight years, respectively, and John Burroughs venerable.

Reminiscences crowd up before me in wind-rows, like the ripening leaves of autumn, or the rubescent clouds of sunset. Brown himself is one of the most charming sportsmen, because he is such a nature worshiper. Ardent, and still not young (indeed, he is what some youthful sportsmen would call an old man), he could make the dreariest camp environment cheerful with fireliglit and genial presence when the weather failed to brighten. Taxonomically he helongs to the guild of camera-hunters, like the still more famous George Shiras, 3d, who hunts the forests for nature study rather than for slaughter. I think that neither of these men aspire to be classed with the mighty nimrods of the age,

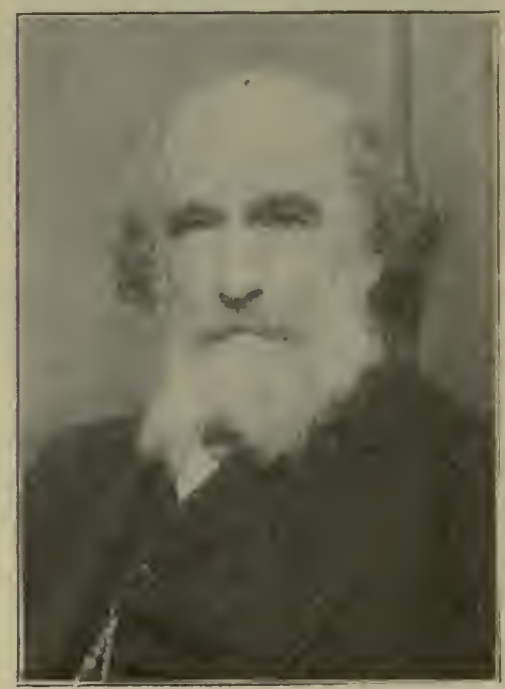

MR, WALTER M. BRACKETT, Venerable Angler.

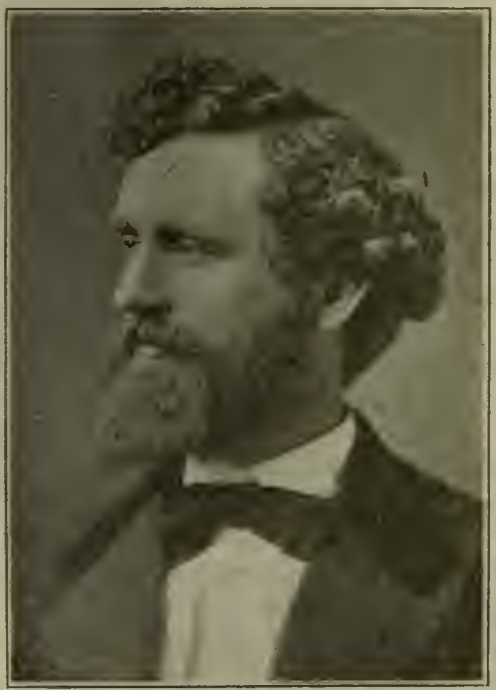

MR. COI.IN CAMPBELL. Famous . Ingler and llunter.

though I reckon their larders are kept well supplied with the game of the country. The litter of fish-bones and feathers around their campgrounds attests to the truth of this surmise. And there are others. H. W. Herbert, better known as "Frank Forester"; Genio C. Scott, a noted angler, and writer for Porter's "Spirit of the Times"; old man Durivage, the author, who lived to be eighty-odd (all of them my acquaintances); J. V. Hayes, one of the first secretaries of the New York Sportsman's Club; Charles Astor Bristed ("Carl Benson"), who fell in love with "Dodo," author of "Kismet" and daughter of Rev. J. C. Fletcher ; Charles H. Haswell, the engineer, of New York City, who died in harness two years ago in his ninety-ninth year; Charles G. Leland ("Hans Breitmann"); Marriner A. Wilder, moose hunter; Sam Knox, son of Rev. John Knox, who tied my connubial knot in 1855, with Amelia J. Wardell; Col. E. Z. C. Judson ("Ned Buntline"); Aaron S. Vail, of Long Island; Stephen Massett ("Jeems Pipes) ; 
Thomas A. Logan ("Gloan") ; L. B. France ("Burgeois"), late of Denver; Hon. Robert B. Roosevelt, Aleck Shewan, and half a score more, of whom only Colonel James Gordon ("Pious Jeems"), Aleck Shewan, Hamilton Busbey and Chas. Banks remain alive. Banks was a member of the New York Sportsman's Club of 1858, two years before me, and is still an active worker in the reorganization of the New York Association for P. G. and F. We used to meet at the old Sinclair House, at 754 Broadway, which was torn down two years ago, where the president erstwhile occupied a chair made of elkhorns which was presented by "Grizzly" Adams, a noted mountain man from the Great Divide, who was contemporary with Kit Carson, Lieutenant Ruxton, Jim Bridger, et al. P. T. Barnum and he fell together at the old museum opposite Saint Paul's Church, in New York, and startling exhibitions were given, to which Daniel and the lions were as nothing.

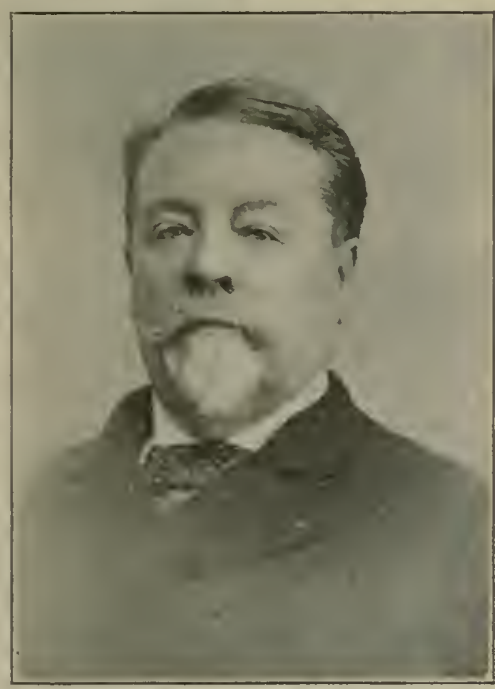

COM. I. L. GREGORY.

Celebrated Salmon Fisher.

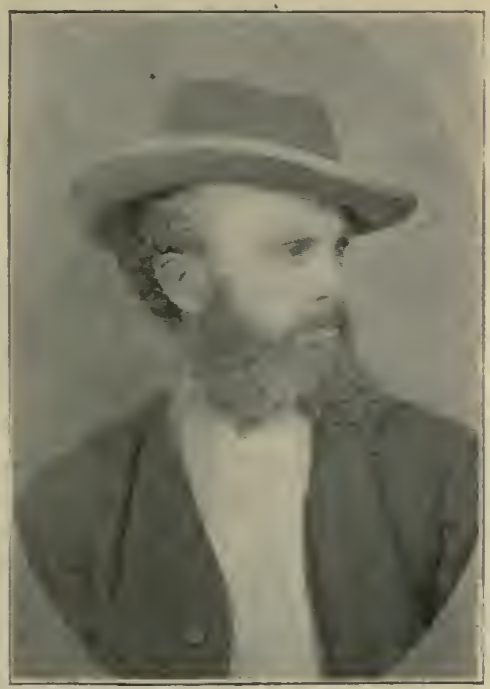

IIR. WV. F. WHITCHER, Veteran Angler.

Then there were Isaac McLellan, who used to do poems for the Journal of Commerce in the forties, when William C. Prime wrote fishing sketches for the same paper over the signature of "W.", and his cousin, Samuel C. Clarke; Daniel Webster. their intimate hunting companion; George A. Boardman; Spencer F. Baird; George D. Lawrence, who donated a marvelous bird collection to the National Museum-all of them eminent naturalists and game seekers, whom I knew personally and often intimately-now gone the way of all the earth.

And now I devote an extended biography to Com. J. U. Gregory, I. S. O., whom we may name as the leader of sportsmen of the last half century. He is eighty years today, living out his honors in quiescence and hope of hereafter. $\mathrm{He}$ is a scion of English, French and New Yorker, the third son of Dr. S. Gregory, who married a French lady in Montreal, and after a time returned to Troy, N. Y., his native place, where J. U. Gregory was born and partly educated 
at the Poughkeepsie Collegiate School. The family returned to Canada when he was about twelve years of age.

Forty-three years ago he was appointed the representative, at Quebec, of the Department of Marine and Fisheries of the Dominion of Canada. He has written many articles on fishing and shooting, and is the author of a book of travels in French, called "En Racontant." He has been several times appointed a commissioner by the government, to inquire and report on the condition of the fishermen on the Labrador Coast, and into the causes of wrecks and casualties to the shipping. He has shot and fished over the coast of Labrador, below and above Quebec, and on two occasions in Florida. He was the founder of the Quebec Yacht Club, of which he is yet the honorary commodore, and also the founder and president for many years of the well-known Tourilli Fish and Game Club, Quebec. Mr. Gregory was one of the original stockholders and contributors to the Forest and Stream magazine, founded by $\mathrm{Mr}$. Charles Hallock.

In his official capacity he has had much to do with the reception of royalty and other distinguished visitors to Canada, and has a fine collection of valuable souvenirs from the present Duke of Argyll and Princess Louise, Lords Dufferin, Lansdowne and Aberdeen, while governors of the country, also from the Duke of Connaught, and recently a very valuable souvenir from His Imperial Highness, Prince Fushimi, of Japan, who landed in Quebec on his way to Japan from England.

Mr. Gregory was amongst the first named by King Edward for a companionship of the Imperial Service Order, and received the badge and star which entitles him to attach the letters I. S. O. after his name. King George IV is at the head of the Imperial Service Order.

Mr. Gregory received a gold medal from the Commissioners of the International Fisheries Exhibition in London in 1883, and a large reward from the Canadian government for his services in connection with the preparation of the valuable exhibits sent from the province of Quebec. Mr. Gregory possesses a private collection of game birds, as well as sea birds, and also alligators and other trophies of his expeditions in Florida, mostly shot and preserved by himself as an amateur taxidermist. We first met and cast our salmon lines on Jacquet river in New Brunswick, Canada, in 1867.

Going back no farther than forty-five years ago it is easy to remember that mine was almost the only salmon rod upon the noble Restigouche, throughout its majestic length of sixty-miles of superlative fishing grounds, a very different state of things today, when its broad swims below the Metapedia confluence are freckled with canoes of guides to club memberships at $\$ 1,000$ apiece! For two successive years in 1865-6 I had it entireiy to myself, barring one Captain Barnard of H. M. S. "Barracouta," a practice ship, then off the coast, whose guns were occupied in battering the romance out of the fantastic escarpments from Escuminac to Tracadigash on Bay Chaleur,-ranging chiefly from the Upsulquitch to old man Merrill's, from Maine and up to Chane's at the mouth of Tom-Kedgewick's and one delectable summer I made the acquaintance of John Mowat, the river guardian at Dee Side. All was solitude between. Occasionally, as the years passed, a stray rod would find its way to the river from some distant region and Aleck Shewan, the pedagogue, got into the habit of coming down every season from Montreal and is still teaching and fishing at the age of 84 ; and so is Hubert $R$. Ives, of the Queens Iron foundry at 79. But there were no accommodations for kid-glove anglers above Dan Yeaser's hostelry, where he and "Black Aleck," of blessed 
nuemory, whom I first met in St. John, in 1864, did the gustatory honors. Gifford Sanford, Alfred Craven and Neill Haversham, of Savannah, Ga., came there. I knew them all. The later anglers, when rod privileges of moderate charge began to be required by the government the leading aspirants of the day, of whom John W. Nicholson, Sheriff Harding, Ed. Spurr, Harry Venning, were the chief, Jas. Lanergun, the actor, Fred Curtis, of Boston, George Jas. Chubb, of St. John, preferred the Miramichi on the Nipissiguit, as being easier of access. Molson, of Montreal, Allan Gilmour and John Manuel, of Ottawa, Ivers W. Adams, of Boston, and half

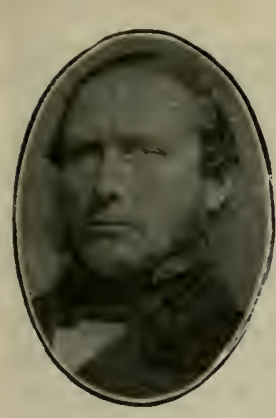

ALLAN GIL.MOUR a dozen residents of Quebec used to go to the Mosie or the Godbout, and an increasing guild began to select the tributaries all along the St. Lawrence; Andrew Clerk, of New York, and his brother, the doctor, chose the Grund of the Gaspe peninsula. Walter Moody, Wyllys Russell, the hotel man, Farquliar Smith, Geo. M. Fairchild, all of Quebec, visited the Jacques Cartier near by, a river which has since passed into dessuetude, but is likely to be rehabilitated under judicious handling. I have a list of scores of noted salmon anglers, but how can I name them all in a limited article? I knew the most of them; quite a number live yet.

These inimitable wielders of the two-handed wand were a rare lot, and all live in the memory of survivors. To the younger fishermen they have passed into oblivion. My "Salmon Fisher," published in 1890, will describe the rushing rivers and placid pools as Nature made them. And there are other books of excellence rare.

As a friend of fifty-odd years' acquaintance, I am convinced that the Hon. Robert B. Roosevelt, who so recently died, has not yet had full credit for the

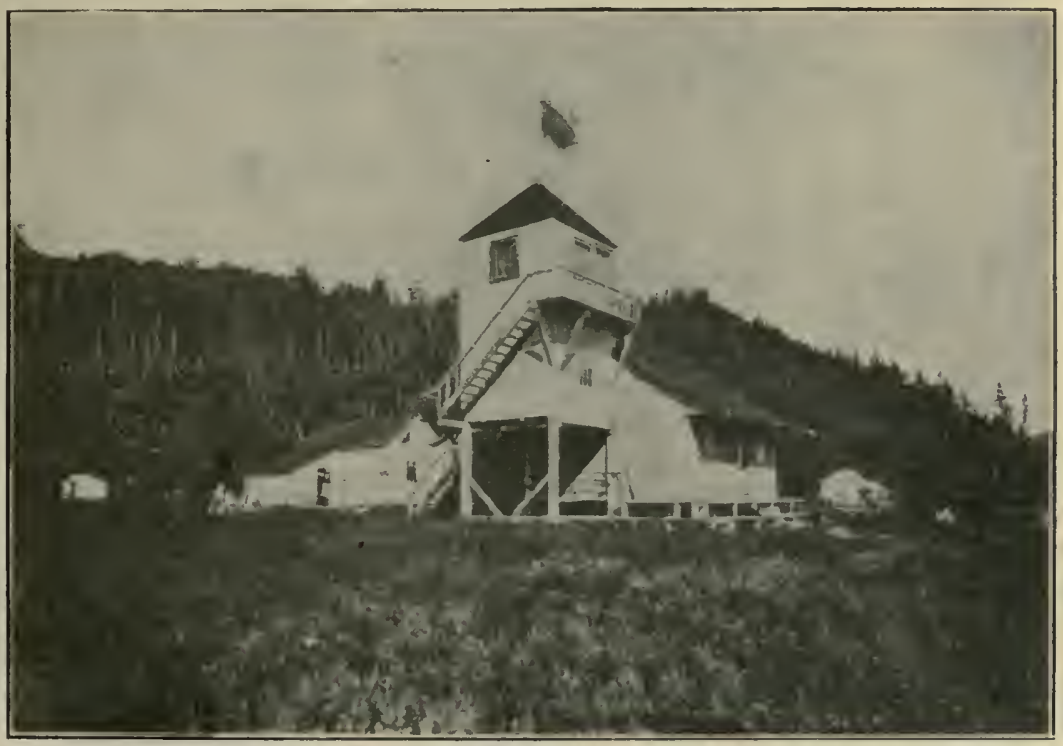


very important part he occupied in the American anglers' guild during his lifetime, especially during the Civil War period, when the young men of the land, and old ones, too, were too much engaged on the battle-fields to spare time for sport, except it were to eke out an occasional deficient ration for the camps by whatever game and fish could be caught during temporary cessation of hostilities. Mr. Roosevelt, it seems to me, was the living intermediate wlio bridged the interval between "Frank Forester" and the writer (if you will allow my claim).

It is worthy of note that the Indians were beginning to be troublesome already, but were not bad. I had already bought a share of Beldon \& Young's addition to the city of Hastings, some twenty miles down the Mississippi River below St. Paul, and they annoyed us by peering through the windows when we were at meals. It was not much of a city, and St. Paul itself then had a population of only 8,000 . Only one railroad touched any part of the Mississippi river, and everything west of it was hostile.

Gen. Henry H. Sibley, who used to write frontier sketches in those days for Porter's Spirit of the Times, over the signature of "Hal-a-Dakotah," was in command at Fort Snelling, and that military post and a hay meadow which was mowed, the cavalry were the only signs of civilization on that side, excepting the Indian village of Mendota, where the general made his headquarters in two stone buildings, which still stand. Franklin W. Steel, Tim Newson, Judge Isaac Atwaster, tutor of my youth, who died in Minneapoiis at eighty-nine years, and Gen. C. C. Andrews, still living, and since then a general in the army and governor of the state, were the principal pioneers, and of course, A-1 sportsmen.

There was no end to game in variety in those days, and fine fish, too, right in the river and lakes all around. It was an jdeal country for sportsmen; and so, when our party of seven started up with a spike team in the direction of Pembina, 400 miles away, we felt we were footloose and in tall grass. But there was a good road all the way, beaten hard by the hundreds of carts which brought down furs every year from Fort Garry and the Selkirk settlement. But that story was written up at the time for Harper's Magazine by myself, and I will only add that when a small band of straggling Indians in the neighborhood of Sauk River, a hundred miles up, commenced to help themselves freely out of the cracker box in the tail of our wagon, when trotting along over the prairie. Aleck Kinkaid, the old pioneer who plotted the town of Alexandria the year before, crawled back from his seat in front and let the forcmost redskin have it under the jowl with his fist. The blow doubled him up, and he fell limp: and all the other redskins, who were not used to that sort of tactics, cried "hough!" and dropped back. It was late in the afternoon and they incontinently went into camp half a mile down river. In the evening they came up and smoked with us. It was midsummer and the days were warm, and they dressed scantily; but every man had his clout and blanket-only that and nothing more. As a rule, the Sioux traveled mounted, but these were a scouting party, who wanted to locate a band of Chippewas who were supposed to be in the vicinity of the Crow Wing Agency. The hostiles got together not many weeks afterward, while I was there at the Agency, and I saw the head chief, Hole-in-the-Day, drive out in a buggy over the prairie to the battlefield, where the Sioux got the worst of it.

I went through a good bit of experience that summer; struck a rainy spell and a freshet in the Sauk River in July; lost all our provisions and part of our camp stuff in attempting to cross a ford, swamped the wagon in eight feet of water, half drowned the horses, lived five days on raw salt pork and water- 
soaked crackers because we had no dry powder, nor matches, nor any fuel to cook with; hadn't a dry stitch of clothing or bedding all that time, and didn't meet a living soul outside of mosquitoes. We got up as far as Fort Ripley in a bad plight, and the soldiers took us in and recruited us-but not for the army! By the time I reached Chicago in the fall, going East, I was exploited as a great explorer and made guest of honor at John B. Drake's fourth annual game dinner, given at the Briggs House. This was in 1858.

At that early date migrants from the East had not begun to meet up with incomers from the West. The tide was still westward. Chicago was in embryo.

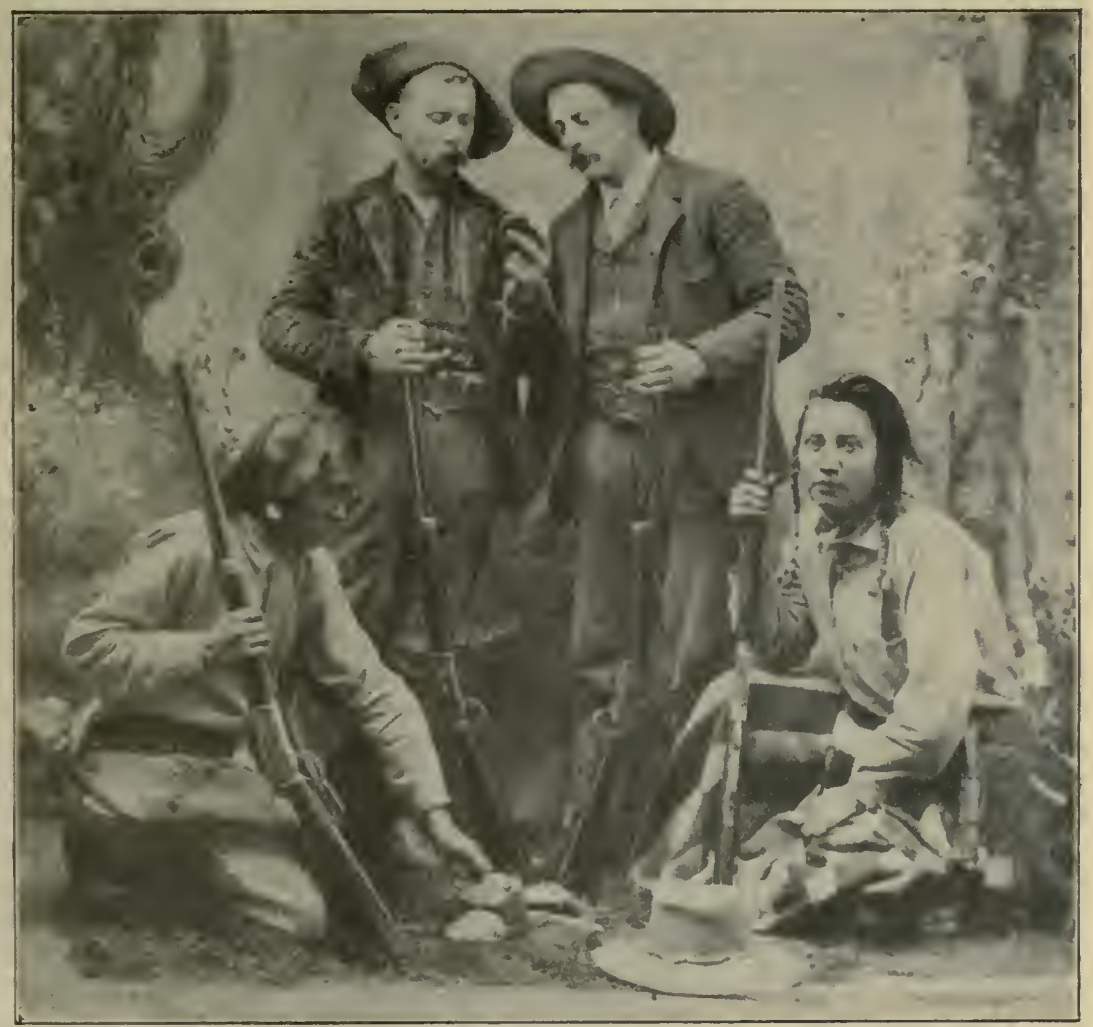

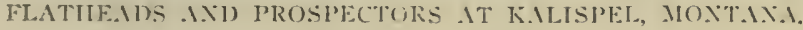

Her streets were higgledy-piggledy, three steps up and two down, here a rise and there a level. Grade had not been established; and when I appeared in town in my soiled and weather-stained prairie costume, the townspeople who had never been any further West took me for a sort of Kit Carson, a Pathfinder, and the enterprising Mr. Drake presented me to his table guests en grande tenue, just as I was. Subsequently this genial landlord opened the Grand Pacific Hotel, and ran it for thirty years, keeping up the game dinners all the while until he died, and the hotel was replaced by a skyscraper. I happen to have kept the menu card of his twenty-first dinner, at which I was also present, and reproduce it 
here. It is interesting to sportsmen to show how abundant game was even then. It certainly ran the gamut:

\section{JOHX B. DRAKE'S TWENTY-FIRST ANNEAL DINNER. Chicago, 1875. \\ MENU.}

Blue Points. Soup-Venison, hunter style; game broth. Fish-Trout, black bass. BoiledLeg of mountain sheep, ham of bear, venison tongue, buffalo tongue. Roast-Loin of buffalo, mountain sheep, wild goose, quail, redhead duck, jack rabbit, blacktail deer, coon, canvasback duck, English hare, bluewing teal, partridge, widgeon, brant, saddle of venison, pheasants, mallard duck, prairie chicken, wild turkey, spotted grouse, black bear, opossum, leg of elk, wood duck, sandbill crane, ruffed grouse, cinnamon bear. Broiled-Bluewing teal, jacksnipe, black birds, reed birds, partridge, pheasants, quail, butterball duck, English snipe, rice birds, redwing starling, marsh birds, plover, gray squirrel, buffalo steak, rabbils, venison steak. Entrees-Antelopd steak, rabbit braise, fillet of grouse, venison cutlet, ragout of bear, hunter style, oyster pie. Salads-Shrimp, prairie chicken, celery. Ornamental Dishes-Pyramid of wild goose liver in jelly, pyramid of game, en Bellevue. Boned duck, au naturel. The coon out at night. Boned quail, in plumage. Redwing starling on tree. Partridge in nest. Prairie chicken en socle.

Among the guests was Long John Wentworth, who had been present at the first dinner, sixty-three years ago.

I doubt if any such bill of fare was ever set up in any land at any period. The Canadian Camp of our time, in a notable attempt at renascence, made an extraordinary display of wild meats at its sumptuous dinner two years ago, and the confines of the earth were levied on; but the selection of viands was not after St. Peter's choice (Acts $x, 11-14$ ) as substitutes for game. The menu would have delighted the Indians at the Crow Agency, who are natural omniphagists, and have a keen taste for miscellaneous comestibles. Chief Hole-inthe-Day, of whom I was speaking, himself had more style about him. He gave me his portrait, which is now in the gallery of the Minnesota Historical Society. He occupied a fairly good one-story house with four rooms, which sufficed to accommodate himself and his seven wives. Although conforming, to a certain extent, to civilized ways, he adhered tenaciously to his aboriginal costume and was more often seen in his flaming red blanket and fancy moccasins than in a dress shirt. When he gave an audience to visitors of consequence he donned a war bonnet of bald eagle plumes, and stretched himself out on a lounge in regal style; each individual feather of said bonnet supposed to stand for an opponent killed in battle.

Allan Morrison was agent at the time, and Paul Beaulieu, a French halfbreed, was interpreter. Allan's elder brother, William Morrison, piloted Henry R. Schoolcraft to the headwaters of the Mississippi not many years before, and Schoolcraft was living at the time. I had a tilt with him in the Evening Post as to priority of discovery. But William had been trapping on Itasca feeders since 1808 , before him. But official recognition of the headwaters were necessary for government acceptance, and Schoolcraft won. Beaulieu died eleven years ago at Leech Lake, at the age of seventy-seven years. He was a loyal servitor, and raised a full company of bucks and breeds in 1863 for service in the Civil War. These agency Indians as I saw them, were not fastidious as to diet. On one occasion they hauled a drowned horse out of the river, and fed on the meat with gusto for several days, as long as it lasted. And yet there was choice game in the woods, game on the open prairie, and catfish in the river! "De gustibus non disputando." 


\section{CHAPTER IV.}

E.IRI.Y RECOLIECTIONS.

HARKING back to my younger days I pick up reminiscences occasionally from along the trails and thickets of my peregrinations which penetrated far into the unsettled wilderness of the United States and Canada-so littie traversed then by railroads west of the Mississippi. Introduced names of defunct and disabled sportsmen I fancy are of no special interest to readers of the 20th century, who prefer fresh memories which scintillate in the public eye, and besides my memory fails and my pen drags. However, I call up an occasional chance meeting from the retrospect, write it for auld lang syne, and kindle it anew around the smoldering campfire. On my old diary I have 2,500 names, dead and living, of whom a very large proportion contributed to Forest and Stream in the 70's-ail subscribers, gun shooters, rod swingers and athletes of the baseball field.

Thanks to my stars! I have had my surfeit of all the enjoyment to be had in the line of sport (fishing and shooting) in days past without money and without price; free to fish the choicest pools in noblest rivers and enjoying the companionship of my canoemen "for what there was in it," and that knowledge of human nature and human arts and wiles which we were able to draw from each other, ignoring caste and despising nothing, roaming the wilds with the freedom of life untrammeled by anxieties of business and apprehension of dynamite and bad men who break through and steal. And let me tell you that my enjoyment of the present passing days and hours is made up of the consolation of these memories of past experiences, with the hopes and promises of joys to come in the future happy hunting grounds. But what the books are made of nowadays are apt to be like the heroics of T. R., who has recently scoured the chapperals and jungles of what remains of the prehistoric wilds of Africa, where Baker, Livingston, Stanley and Paul du Chaillu put in their hunting grounds, whence Paul returned in the 50 's, bringing the head of a swinging club gorilia mightier than the talking anthropoids of Prof. Garnier of today.

As the venerable Isaac McLellan, who died at 92 years of age in 1893, wrote with ecstasy, so write I now-albeit homophones-all words which sound alike but may have different meanings. So I quote:

"Pleasant it is for a traveler after a long day's journey to pause at some elevated hilitop for rest and retrospection, and to take a compreliensive view of the route lately traversed. Far as eye may reach, even to the horizon's misty edge, he sees beneath him outspread like a map, each lovely spot he has visited. Far off in distant obscurity shines out the starting point of his career; and even so can one recall the scenes and events of his early time of youth. All these regions of resort still survive freshly in the memory of the veteran sportsman, even as the scenes of the traveler's adventure are present to his eye and mind as he surveys the features of the natural world, through which he has lately journeyed. Now brightly are photographed in memory the names, forms and features of those old friends, who were the associates of the thoughtful sportsman and schoiar in the years departed."

$\mathrm{He}$ adds: "My earliest experience with the gun was in wild pigeon shooting, 
more than fifty years since. Those beautiful birds were then very plentiful in New England and I liave shot them within a few miles of Boston. They were then shot by the concealed gunner as they collected on a tall pole, like the oldfashioned well-sweep. It was usual to bait with grain the ground beneath, and the flock wouid gather there for food, first alighting on the pole and then settling to the feast. This bird had great strength of wing. It was said to travel at the rate of a mile a minute and it required a good marksman to stop them."

Following him closely in this recital of incidents, now extinct, my venerable kinsman, Nicholas Hallock, of Ulster county, New York, a lusty fox hunter now of 84 years of age, called my attention the other day, while we lunched together, to the sport he had among the wild passenger pigeons in the state of New York in the 40 's, and I claimed to have had some gun practice at the same time; for while I was fitting for Yale College at Hart's Classical School in Farmington, Conn., the principal kept my percussion cap gun in his study for occasional use on outings and holidays. I was the only scholar who had the privilege, and I frequently brought in a bag of pigeons, partridges and quail, which I was obliged to wade for by fording the canal up to my armpits; and when the meadows were flooded in the spring old miller Holt's son and I shot muskrats galore from a pungy skiff. Thousands of the wild pigeons were shot constantly at the trapshooting conventions of sportsmen from that mid-century date up to the 80 's, or thereabouts. In those far back 40 's the birds were carried in baskets for long distances on canal boats towed by six horses trotting against railroad time, which ran not much faster then. They were so roughly huddled together that they so seriously suffered from long confinement that twenty per cent of them died, and when the survivors were turned loose at the shooting line they were too tired to take wing, and so the starters would throw a baseball at them to make them rise. Such cruelty was insufferable among game and humanity and hosts of pigeons took flight for the West, making Wisconsin their chief nesting place and home. I remember taking a trip on one of these primeval canal boats on the Erie, which was fitted $11 p$ comfortably with statesooms for emigrants moving west.

My cousin, Nicholas, resided in Queens county, Long Island, when the Hempstead Plains were crowded with "fur, fin and feathers." The scrub oaks afforded cover for deer, quail and foxes. Even today the midland woods and swamps are almost an undisturbed preserve for forty miles from North Islip to Riverhead, where I have hunted quail with the Wagstaff boys not far from Babylon, sixty years ago, on their father's demesne. Both of the now oid gentlemen are taking active lead of the New York Game and Fish Protection, and ex-Senator Alfred is its president. The Soutl Side Club, with the far-famed actor, J. K. Hackett, president, was a favorite resort in the 60 's, when John Stellenwerf was chef there before he took charge at Blooming Grove Park in the 70's. Aaron Vail ran a high-class angiers' club at Nort Islip, near where the deer, foxes and rabbits took convenient cover. The terminus of the main railroad was just beyond at Farmingdale. Across country, on the south side, Austin Roe kept hotel for anglers, with his fine trout ponds at Patchogue. David Hartt held forth at Good Ground, not far away, where ducks dabbled, and down at Fire Island, where Sammis was landlord, I spent one Fourth of July with the Benson boys on the Great South bay, and heard Joel Headley make his address in the evening. Then there were the Maitland, Minell, Massapequa and Maspeth trout ponds, owned by Wm. H. Furman, Wm. Floyd Jones, Shepard Knapp, Aug. Belmont and the tobacco Lorillards, all famous fishermen in those days gone, 


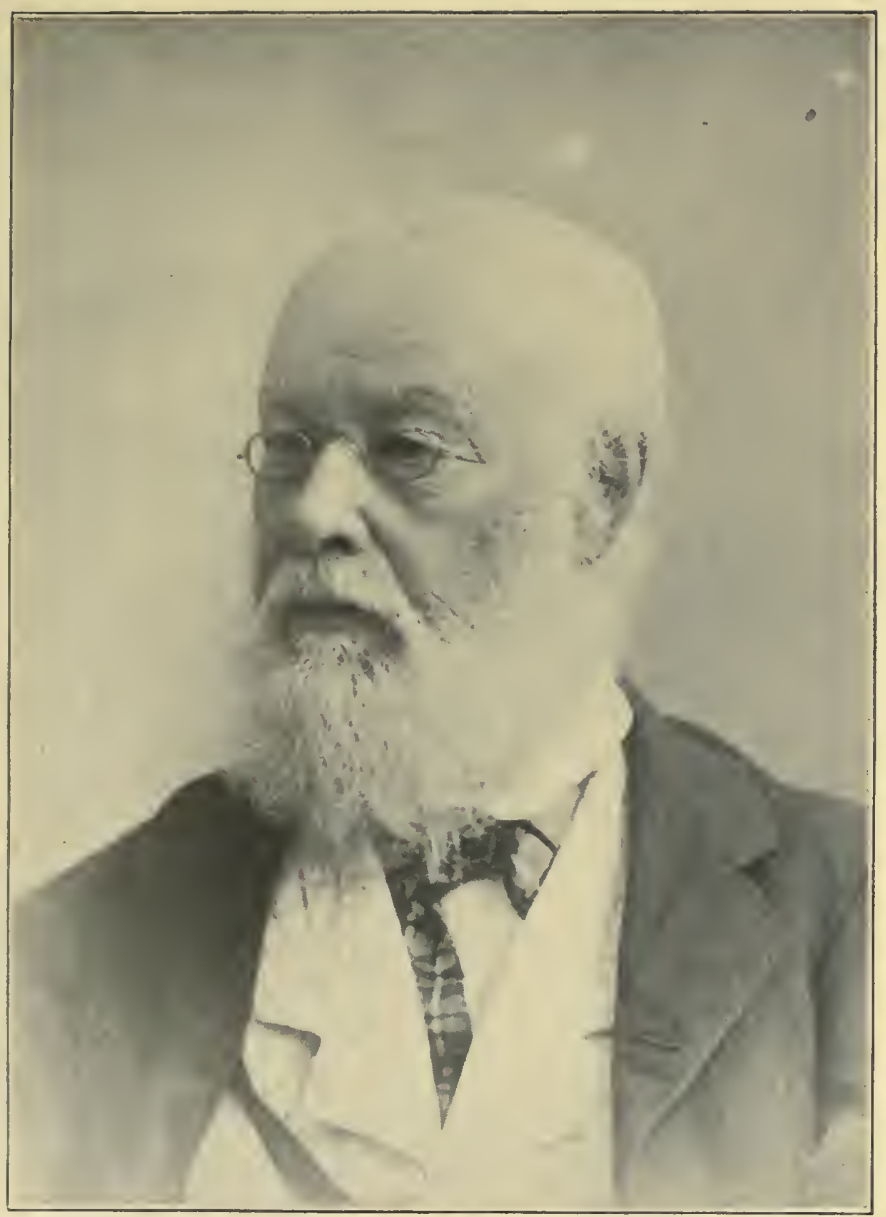

ISAAC MCLELLAX,

"THE POET-SPORTSMAN." 

included in my reminiscences and now buried under ground-ponds and contents, fish and all.

Those were great days, tọo, at Conk Vandewater's, on the South Oyster bay, where the two Judge Bradys and I went sniping on the marshes, and where I met Fred Mather one day and carried him papoose back, Indian fashion, with a pitchfork trident over his shoulder, bearing seaweed representing Neptune rising from the sea. The Keiths had a marvelous sparking trout stream, which ran through the woods, and employed a lusty pugilist to protect the property from poachers, who used silken nets as fine as hair meshes and set them in darkest hours. And one night when I was at their shanty with Rev. Jos. L. Duryea, of Brooklyn, who had driven down the island with me in my wagon, we joined them to lie in wait for the trespassers. We had already discovered the seines, and laid by to watch them lift them ont. Slyly thev proceeded, and cautiously, and the bouncers did the rest.

Down at the east end of the island there are opossums in such numbers as to be a nuisance, and they are found nowhere else in New England.

From Riverhead west to Islip the unoccupied country is like the plateau which lies north of Fayetteville, N. C., largely covered with scrub oak interspersed with pine clumps and scattering pines, and bedded with frequent patches of white beach sand of ancient deposition threaded by paths running in all directions. Oak hammocks alternate with swamps, swales and creek bottoms which harbor deer, rabbit and quail, and with ponds and outlets which abound in trout, bass, perch and builheads. Crows, cranes, ducks and bitterns fly from marsh to marsh. Hawks and snakes keep the rodents and other vermin pretty well thinned out. Here and there along shore may be found the seine of the fisherman, his fish house and windmill; clumps of bayberry bushes; sailing craft at anchor; skiffs, punts and pungeys drawn up on the shingle or nestling among the sedge grass on the creeks. No less than one hundred steam and sailing yachts go into winter quarters at Greenport alone. I could fill up my chapter with Long Island reveries, and on the spur of the moment I recall that only last summer I dined with $C$. F. Creary and David Edgar at their bungalow, while their steam yacht rode at its anchor before us-recalling how we and,Will L. Brooks, owner of the Clytie, of the New York Yacht Club, spent our winters forty years ago at St. Augustine, Florida, where we kept canoes for sport at the club house down there. I have a gruesome tale of how Brooks was run over by a steamboat in the Race near Plum Gut once upon a time and saved his life in some wonderful way after being afloat ten hours on driftwood. This reminds me that shooting coots and sea ducks over decoys outside of surf which rolls up among the rocks along the coast from Montauk to Maine, the gumners anchor their boats outside the swells and let their decoys tail in shore, where the feeders join them among the breakers. The game is captious, but the combined wave motion makes good aim and gunshot difficult.

Back in the 50 's woodcocks probed for angie worms all around the environs of New York City; perch and sunfish fanned their fins in the collects; snipe worked the Lispenard marsh above Canal street; striped bass were canght at McCombs dam below High Bridge; blackfish and canners took fiddlers and crab bait at Carnarsie, around the wreck of the Black Warrior; tide runners at the Narrows showed up four-pound weakfish; sea bass took the hook all around the Brothers at Hellgate; and our best sportsmen, like Valloton and Genio C. Scott, hung up big striped bass at Cuttyhunk on eel-skin.squids, and drumfish at Barnegat and all along Chesquake creek, where fish swam on tides and ebbs. 
Tom Havemeyer went down to Cobb's Island after piover, and to Martin Point and Back bay, near Norfolk, after ducks and black and yellow-leg waders. Trout were alive in the Morrisania and Pelhamville ponds and jumped for artificial flies in the muse-be-written Bronx. Dr. Robert T. Morris, who inherits 300 acres of his ancestors, writes to me that game and fish can be snared and shot within the metropolis this very day, within seventeen miles of the Grand Central depot. And his graphic pen runs in this wise:

"About two hundred acres of mv country place in Greenwich and Stamford is to be devoted to experimental nut orchards, and I am mailing to you an article which covers the field of my ambition. The rest of the place is to be kept in forest, for two reasons. One reason is because I love to have the Adirondacks within seventeen miles of Grand Central depot, and the other reason is because the cliffs and swamps forbid agriculture of any sort. There is more than a mile of the Mianus river on my property, and some big trout there. Take the canoe out of the barn and go a-fishing any day you please this spring. You can find deer tracks in the sand and flush a partridge or quail along the bank.

"With kindest regards.

Yours truly,

"ROBERT T. MORRIS."

Dr. Morris is the chief of the advisory board of the Canadian Camp, and Dr. Lenox G. Curtis leads them all. We older members remember well when Andrew Clerk, Jim Conroy, Wm. Mitchell, Dingee Scribner, Chas. F. Orvis, the Pritchards, Welch and Leonard, made the greenheart, ash, lance wood, and split cane rods, for the anglers, and Dr. J. G. Wood, of Poughkeepsie, cast the longest fly line at Watertown, N. Y. Orvis is still living at Manchester, Vt., at 80.

But my time is speeding. So I remark in an off-hand way that my first twenty years were devoted chiefly to the pursuit of knowledge in and out of school. In my twenty-second year I took my wedding trip with a wife just married, and took her down the St. Lawrence river, where a lurch of the excursion steamboat nearly pitched her into the Lachine rapids when she was looking at the rocks over the side. The notable officer captain Boxer who fought his battleship off from the Pei-Ho forts in China caught her by her clothes and saved her life. This was my first acquaintance in Canada, and it goes on to my reminiscences.

"The first time I remember to have been with ladies in camp-for I had been trained in a rougher school-was in 1859, when the Rev. Joseph C. Fletcher, who had been United States Secretary of Legation to Dom Pedro of Brazil, headed a party of thirteen couples, with guides and luxurious camp appointments, made up. at Houlton, Me., in the Aroostook country, and went down to the Grand Lake Stream near Rev. Dr. Bethune's favorite camp at the outlet, to fish for landlocked salmon. It was during the era of hoop skirts, and when the ladies discarded these contraptions upon retiring at night and hung them up in the moonlight at the front of our long, open-faced tilt, they looked like monster spiderwebs. The first woman adept with the gun that I ever knew was a sister of Gurdon Trumbull. the artist, of Hartford. She was the wife of William C. Prime, and with her noted husband was abroad shooting pigeons on the Egyptian Nile from the deck of a dahabiyeh in 1848. A Swiss lady, the wife of Fayette S. Giles, who was the first president of the Blooming Grove Park Association in 1870-71, together with the wives of other members, used to make up the femaie contingent at the Park hostelry in those days; but they seemed out of place then in a boys' game. Adirondack Murray encouraged the presence of women in the open woods until it was charged that the whole New York wilderness was littered with parasols and bits of lingerie, the jetsam of ladies 'going in.' 
Two more little items are worth noticing: One, in 1856, when I came up from New York to New Haven with Prof. T. S. C. Lowe and his assistant, David Main, of Calais, Me., in company with their balloon. The same old bag was used most successfully afterwards in the Civil War. The same astronomer is now in charge of the Lowe Observatory of California, and doing good service at the age of 96. Second, it was the same year when my friend, A. B. Keeler, left his clerkship in Wall street, New York, and went into business at Fort Benton, Missouri river, under charge of the Conrads, where the elk rubbed their velvet horns on the lodge-pole pines in Judith Basin, and redskins laid low.

In 1858, in July, while I was one of Geo. F. Brott's party of five, with C. C. Andrews, Aleck Kincaid and others, driving a spike-tail horse team over the "Red River Trail" from Minneapolis to Ft. Garry, we met a string of 120 shrieking two-wheeled carts, unironed, freighting furs from Selkirk to St. Paul, and fighting mosquitoes across the prairie in the charge of half-breed Crees, one to six carts drawn by oxen between the shafts. It was a tough chance in fly-time, and we all suffered. The animals were rounded up at night and smudged, and some of us had Bermuda tar and oil for protection. There was no Winnipeg then. That town was started in 1871.

I spent the summer of 1859 among the lumber camps of the Aroostook and Madawaska, in Maine, and the summer of 1860 in Labrador and Newfoundland, bringing out the first photos of the interior ever taken, and the camera man, F. W. Knowlton, is still at the same old stand at Northampton, Mass., at the age of 74 . I wrote up codfishing, cariboo hunting, gnat swarming, and the principal features along shore and up the great Eskimo bay as far as the Hudson bay posts, Rigolet and Northwest rivers. During the first part of the Civil Warr I ran the blockade by land and water, taking in Nassau and Bermuda, and from 1863 to 1868 I traveled over the Maritime provinces and lower Canada and their outlying islands, Cape Breton, Anticosti and the Magdalens (Coffin island included), acting as correspondent for the Halifax Citizen and St. John Teiegraph. Joe Howe, the "Blue nose" premier, then said that I knew the country better than he did. Much of what I learned was printed in my "Fishing Tourist," which appeared in the spring of 1873 .

I passed the wirters of 1869-70 anrong the Sea Islands of Georgia and South Carolina, and the five winters following in Florida, culminating with a book entitled "Camp Life in Florida." During the ten following summers I was able to do the Great Lakes, Georgian Bay, the back lakes of Ontario provance, the St. Lawrence river and many of its tributaries, Anticosti island, the north shore of Lake Superior, the Nepigon, the Michigan peninsulas, Mackinac, the knobs of Pennsyivania, covered by the Blooming Grove Park; the moonshine region of western Virginia, North Carolina and East Tennessee, the coast highlands and pine barrens of New Jersey, the interior of New York state and the tide water regions of Delawarc and Maryland. All interior excursions were made with camping outfits by canoe, wagon and saddle. I used to travel light, excepting where canoes were required, and never carried a tent until I was 54 years of age. It was easy to make a camp or "lean-to" if the weather was bad, or to turn the canoe over for a night's shelter and cover up under a rubber blanket.

And that reminds me of a camp which Colin Campbell and I had at Hamilton Pool on the Nepigon fiftecn years after. Campbeil was a born Nova Scotian, and is now a member of the Lawyers' Club in New York City. $\mathrm{He}$ has always been an expert moose hunter, salmon fisher and mining prospector, and can "endure hard- 
ness like a soldier.", He has a place (the old family homestead) at Port Medway, Lunenburg county, Nova Scotia, and I think kills his moose and a score of salmoin every year, and so did Mariner. A. Wilder kill his yearly moose till he died at 87 . He first introduced me to the Indians, Noel and Saul, who are experts in moose calling and fly-fishers hard to beat, though John, Manuel and Napoleon Comeau, Allan Gilmour's river guardian of the Godbout, lower St. Lawrence, have records which will take the varnish off of any other exploits and scores. But about the Nepigon menu! Canpbell and I had two eighteen-foot birch canoes, with two paddlers to each; three of them Crees and one an intelligent half-breed named John IVatt, whom we procured at the Red Rock Hudson' Bay Company's post, with our outfit and permit to fish. We were looking for mineral, especially silver ore, and expected to be absent ten weeks. I append a copy of the permit which was issued forty years ago. It will be interesting at this date, when heads are gray. No license fee was required:

\section{SPECIAL PERMIT}

Granted by Order of the Minister of Marine and Fisheries to Foreigners.

The holder of this permit, Chas, Hallock, Esq., having duly applied, is allowed to angle from 26th June, 1873, to 1st October, 1873, in Canadian inland waters, within the district of the Fishery Overseer countersigning underneath.

This permit is NOT TRANSFERABLE, and requires strict conformity to the various provisions of the Fishery Laws and Regulations.

Issued at Ottawa, 18th July, 1870.

Countersigned and dated at Red Rock, Lake Superior, Ontario.

Jos. Wilson, Fishery Overseer.

M. F. Whitcher, Commissioner of Fisheries.

This permit was signed by Robert Crawford, who had then superseded Wilson. He was a hard-handed but genial Scot, who had such a grip to his greetings that few cared to shake hands with him twice. I soid him my "Perry rifle," which was a breech-loading self-capper, described in one of Frank Forester's books, with plate, and was a capital tool for zero weather, when fingers were too numb to manipulate percussion caps. Crawford afterwards went to Ungava Bay post in northern Labrador, and was succeeded by one Flannigan, who was residing in St. Paul as recently as 1897 . I knew them both. Of the goods which I took in exchange for the rifle was a pair of Bedford "cords," which served me in good stead until 1895, in varied stress of wear, until I finally turned them over to a colored boy in Pollokville, N. C., in that year. IVe had just come off a wild turkey hunt near Prettyman's lumber camp. Thirteen years before, when I was a guest of Capt. George K. Sanderson, of the Eieventh U. S. Infantry, who was senior captain at Fort Custer, Montana, I had reinforced the leggins with a pair of dress bootlegs, which made a capital seat for saddle use in many a subsequent ride, of which the most notable was a seven-weeks' campaign in 1878 with Major Jacob Wagner, of the U. S. Mounted Revenue Police, in Ashe and IVatauga counties, North Carolina; Johnson county, Tennessee, and Scott county, Virginia. These counties are in the Blue Ridge, and we three rode 1,200 miles in that time over "hogbacks" and trails, fishing for mountain trout and hunting illicit stills, of which we located no less than 164, besides fighting off hogs which would stand us off on the passes and try to hamstring our horses. We had to shoot one of them to get past. One of our diversions on that outing was shooting for "beef" with the 
mountaineers, but our Springfield carbines proved superior to their Kentucky rifles. The record of this trip occupied a page of the New York Herald soon after.

Returning to the Nepigon, as before $\mathrm{mv}$ long digression: I was saying that no fee was required from angiers. The monster trout and pike were as free to our hand as if we owned the royal preserve ourselves. And when we arrived at Nepigon House on the Lake, factor Henri Le Ronde and his half-breed son Charley, who had been educated at Toronto University, showed us a 16 -lb. speckled trout, which I believe is still the record fish of the species fontinalis. On July 4 they put up a series of canoe races for Indians, both sexes, and for twelve, fifteen and eighteen feet craft (one paddle, two paddles, four and eight paddles), and Campbell and I won in the two-paddle class with a twelve-foot birch.

But bless me! how long I am getting to that aboriginal menu at Hamilton Pool. Guests of the Canadian Camp Dinner at the Hotel Astor would become impatient by this time, but hardly ravenous, I think, when they saw the viands. The how of it was this way: Colin Campbell, my angling friend, and I were enjoying the evening meal which the handy John Watt had put up for us, when we heard a wrangle in the guide's quarter, and went out to ascertain the cause. We found our three Indian paddlers seated around a bianket playing cards. The stakes were on the niddle of the blanket. It seems that they had trapped a gravid hare that day, and opened out three immature young ones. These were the prizes contested for, and each of the players was eager. When the case was decided the winner raked in his plunder, and forthwith proceeded to spit each one, hair and all, and toast them over the fire. When all were good and crisp he ate them as one would bite case sausages, and he was that greedy that he never offered to share with the others; but Campbell and I did not hasten to be invited.

Ravenous! I was on my way to the Red river portage, or rather to the Culebra Cut of that day, which was to open navigation from Red river to the Mississippi, when I wandered off to the Nepigon, and I only have now to add that the seventy-foot steamboat, "Anson Northrup," which had been hauled over the prairie in detail and put together at the entrance of the passage through the marsh, ready to proceed, was never floated! Her bones are there yet, and I believe that Capt. Griggs, of Grand Forks, N. D., who was to take her through, is also hung up somewhere twixt heaven and earth, if not still living at Grand Forks. Yet I think that the real pioneer of Red river navigation was Capt. A. E. Maloney. He brought the first steamboat up in 1872, continued freighting for four years, and then became proprietor of the "Ingalls House" at Grand Forks. Old Charlie Cavileer, for a long while in the Hudson. Bay Company at Fort Selkirk, and for many years postmaster at Pembina, could tell us if he were living; but he died five years ago at the age of 86 or so; or Bill Moorhead might know, or Nelson E: Neison, the old customs officer there for a quarter of a century; or ex-Representative Jud La Moure, who started so many towns in the northwest corner of Dakota Ter. in the $70^{\prime}$ s, and for whom Ia Moure county in N. Dakota is now named. All the parties I have named were pioneer hunters and marksmen of high order as long as forty-five years ago, or more, but the keenest of all crackajacks in that region is old Cavileer's son Ed, a younger man, who is now postmaster at Pembina, like his father before him. For ducks, chickens, geese and all the game of the country he has no rival, and his gun or pistol are just as good as a hammer to drive nails and plug swinging coins. I shot with him often.

It was in August, 1880, that I completed the "Hotel Hailock," on the line of the Minneapolis and Manitoba railroad, in Kittson county, and we had some marvelots 
sportsmen there and no end of game at that time. E. W. Jadis, E. H. Fullerton, Andrew Sanmatt, Bill McGillie, a Scotch half-breed, whose father had served the Hudson Bay Company, the Benson boys and the Carneys were in the lead, especially for jumping deer, moose, elk, bear and other big game, which was common enough then. Bands of elk came within a few miles of town; once a moose ran directly through the viliage, past the post office; a black bear came up out of the botton to play with the school children at recess; a couple of pet bears were always kept on hand for the Swedes to practice boxing on; wolves would tree settlers in zero days when food was scarce; one winter I had an empty store half full of pelts of both timber wolves and coyotes; prairie chickens nested on the edge of the town. Out on the Roseat1 there was a famous nesting place among the reeds for wild geese, and mallards and teal afforded good sport. Dean Benson took the Philips party out (they were from Penn Yan, N. Y.), and at the end of three weeks they brought in seven moose, two elks, five deer and seven wolves. This was in October. The Indians used to bring in considerable game and fish (pike) from that section, and once a son of Chief Koopenas killed a whisky trader by way of variety. Another chief named Mikenok had been in the earlier tribal wars and lost most of his scalp. It is not often that a man lives after losing his "top knot," because as a rule he has first been clubbed, shot, knifed or tomahawked.

Judge John Swainson, of Upsala, of Sweden, and I laid out to raise a stock company for a sportsmen's hotel and game preserve and got a few thousand doilars subscribed, chiefly from St. Louis people (Col. Hunt and friends), and Joln Davidson, of Monroe, Mich., and A. W. Hubbard, of Philadelphia, came up and shot over the ground, and so did Jim Hill, several times. Andrew Carnegie made me a call in his private car. But the prospective millionaire declined to help, and the scheme fell through for want of a brace. The hotel had a precarious record for twelve years, and was destroyed by fire onc Christmas eve. I had no insurance.

But sakes alive! How I do ramble, sure enougln! I have run fifty years ahead of my chronology! When I left the trail I was working over a list of sportsnen I had met in my adolescence and early manhood; and as I hark back memory opens out a whole galaxy of illuminati whom I met casually in the sanctum of $\mathrm{Wm}$. T. Porter, the "Tall Son of York," in the 50's, while I was on the Journal of Commerce editorial staff. I was then contributing some wild west sketches for the "Spirit of the Times" over the signature of "Lariat," and that is why I dropped in.

Charles Banks was a member of the N. Y. Sportsman's Club in 18.58, two vears before me, and is still an active worker in the reorganization of the New York Association for Protection of Game and Fish. We used to meet at the Sinclair House, at 754 Broadway, and the president occupied a chair made of horns, whicl was presented by "Grizzly Adams," a noted mountain man from the Great Divide. P. T. Barnum and he fell together at the old Museum, opposite St. Paul's church, and startling exhibitions were given, to which Daniei and the lions were as nothing. Then there were Isaac McLellan, who used to do poems for the Journal of Commerce when $\mathrm{W} \mathrm{Vm}$. C. Prime wrate fishing sketches over the signature of "W." and his cousin, Sam'l C. Clarke; Daniel Webster, their intimate angling companion; George A. Boardman, Prof. Henry and Spencer F. Baird, of the Smithsonian; Robt. Ridgeway, X. Y. Maynard, Edward A. Samuels and his partner, H. H. Kimball; Geo. D. Lawrence, who donated a marvelous bird collection to the National Museum, the latter eminent naturalists and game seekers whom I knew personally, and often intimately, now gone the way of all the earth.

Lieut. Geo. F. Ruxton, of the English army, exploited all the notable plainsmen 


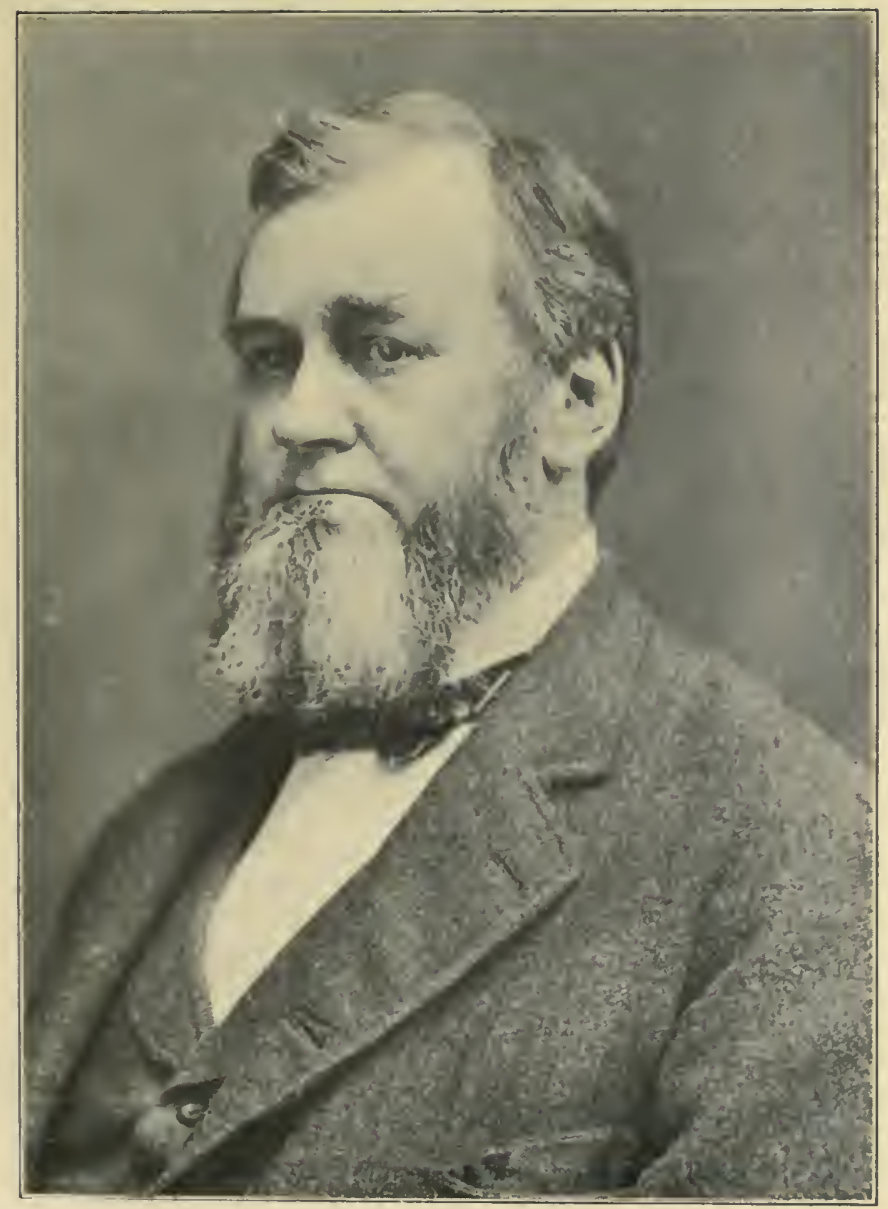

SPENCER F. BAIRD,

FIRST U. S. FISII COMMISSIONER. 
hunters and trappers up to the date of his "Life in the Far West." Mountains, lakes and buttes commemorate their names: Fremont's Peak, Lake Bonneville, Williams Creek, and the rest. Capt. Jim Bridger wrote up the Yellowstone country and was classed by incredulous readers with the father of liars. Jim Beckworth, a mestizo, born in St. Louis, whose whole family had been massacred by Indians on the plains, got someone to edit his remarkable experiences and put them into book form. Lieuts. Emory and Geo. M. Wheeler, and Profs. Suckley and Bailey, all government experts, had followed on the trail of Lewis and Ciarke, Pike Fremont and Marcus Whitman (a pupil of my grandfather), and laid open the secrets of the Great Divide on both slopes. I suppose it was the perusal of these books which drew me to the unexplored region west of the Mississippi, which was marked "desert" on my school map. In 1840 there was not a modern hamlet west of the Mississippi; only remnants of the prehistoric civilization in the southwest and northwest. The Mexican war opened up a part of the southwest and Santa Fe traders and Forty-niners did the rest. Mormon emigration and the Oregon colonists laid open the northwest, and the completion of the Union Pacific railroad, in 1866, let in the riff-raff. After that existence was made uncomfortable for buffaloes and Indians. My old Pennsylvania friend, Starkweather, had married a Norwegian girl and moved out from Potter county to the Menominee district in Wisconsin in $185 \bar{T}$, and I fell in with him out there the next year. At the same time I met up with Dr. W. Frank Powell ("White Beaver"), of the Buffalo Bill type, at La Crosse, when it was only a steamboat landing and grain warehouse under the bluff. I also made the acquaintance of Gen. La Duc and Banker Follett, both still living at great age in Minnesota.

The renaissance of the gentleman angler had not yet revived in society. There had been a hiatus of four centuries since Dame Juliana Berners was Priestess of the high hook, which even Izaak Waiton and Kit North could not awaken into a furore. This interval was devoted to commercial fishing off the coasts of Greenland, Labrador, Newfoundland and Sable Island. Nevertheless, there was dear old William C. Prime, of "Lonesome Lake" in the White mountains, up back of the Profile House, who wrote effusively of the "Old House by the River" and the "Owl Creek Cabin Letters," in 1848; and there were others whose advent into the province of fluvial sport helped to inaugurate a new era. Prime died at East 23d street, New York, a year ago, at the age of 83 , surrounded by his curios and trophies. It was the last house retained for residence purposes in the block. But before I go farther I will say that to cover the list of sportsmen whom I have met during my travels through all the states, provinces and territories in the United States and Canada, from the Arctic belt to the Caribbean sea, and mention them all, would require perhaps 2,000 names. Of these I have filed autographs of one thousand. Nevertheless I will begin to shuck out the pile in my next paper, which I trust will have more red ears than this one. 


\section{CHAPTER $V$.}

IN THF, SUNNI SUCTH.

Jorting down my younger wandering trips and travels, one of my first winters was in 1860 , after my return from Labrador, to report the Democratic convention for nominating the next President at Charleston, S. C. It was an unfortunate division of delegates, and when the Douglas section was moved to Baltimore, old Dan Mixer, proprietor of the Charleston Hotel, wrote me a free railway pass thither via Richmond, Va. As the South stood for Breckinridge, of Kentucky, I sent a substitute to Maryland while I remained a while down South to visit some resident Amherst college graduates who were D. K. E. fellowmembers with me in 1852-3. On said occasion it was my good fortune to contemplate the negro in his highest estate "befoh de wah." His condition of servitude was really enviable. He had ail that he wanted and small care. His social status kept pace with the families to which he was attached. His African ancestry cut small figure.

In Savannah I met up with Hon. William H. Stiles, who was minister to Austria under President Pierce. His son, George Stiles, was captain of the Savannah Volunteer Guards. (Now, this is not a hunting story, but it has to do with guns, so it is apropos.) The Stiles family occupied one of the sea islands in Warsaw Sound, near White Bluff, where they raised long staple cotton at 37 cents a pound, and kept blooded stock-horses and cattle-which ran wild during the war, as the piantation was abandoned at the time. They had also a large contingent of farm hands and house servants. The musicians of the Volunteer Guards was made up from the males of this (Green) island contingent.

On one occasion Colonel Stiles invited me down to the plantation, where he said he thought I would like to hear "a couple of his fifers" play. The band comprised some twenty musicians in all, enough for a good-sized drum corps. We found a neatly white-washed cabin, where the Colonel, while he went in quest of the fifers, left me with a matronly old colored woman, and a small pickaninny crawling about the open fireplace, with its mud and stick chimney.

"Now, if you will hold the baby," said the Colonel, when he returned, "Auntie will make us an ashcake while the music goes on."

The men put the instruments to their lips, but I did not hear any fife music, only what seemed at first to be the soft twitter of a singing mouse, apparently coming from behind a dresser. Then there was a mingled sound like the low warble of canaries; first and second parts began to be audibie, with more rythm and cadence to the notes; finally swelling into fullest volume. Such harmony, I dare say, has never been produced on instruments of this class. Could these performers have been shipped to Koster \& Bial, in New York, they would have commanded unprecedented prices and crowded the houses to repletion.

Not long afterwards I began to visit Florida. Some phases of my acquaintance with that part of the country appeared in my book, "Camp Life in Florida," which was published in 18\%6. In fact, I have spent one-half of my life-iong winters in the South, taking in all the states from first to last, and I may as well tell your readers what they will never hear from present generations what kind 
of plantation tidbits the negroes liked before the war. Only the old survivors can tell you how a real hoe-cake used to be made. It is sung in the Old Dominion that

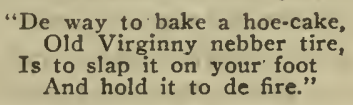

It is simply a mixture of corn-meal with water and a little grease, made flat and stood up before the fireplace on the back of a heavy plantation hoe. It was an invention of old slave times, and is used generally to this day among the lower classes. Game hunters always carried a couple of hoe cakes in their shooting jacket side pcckets and sat on a fence at noon and ate them with peeled turnips pulled from the fields. Another favorite relish is corn pone made of meal and sour milk with a little shortening. It used to be made in an old-fashioned Dutch oven with a handle and cover and baked in the hot coals in the fireplace. When done an expert cook seizes the pan by its handle, throws it up in the air, gives it a turil and a flop, and catches it on a platter all ready to serve. Ash cakes are the same as hoe cakes, except that they are cooked in the ashes between two cabbage leaves or corn shucks. Boiled corn meal, called dumpings in eastern North Carolina, flapjacks, Johnny cakes, corn dodgers, boiled corn muffins round, gems oblong, spoon bread, egg bread, corn mush, boiled cracked hominy, kernels soaked in lye and shelled corn pounded in wooden pestles constitute the main menu of the antebellum colony. Sportsmen cannot readily dispense with this table d'hote at home or in the open field-not even in aristocratic cuisine. Good old Frances, superlative cook for Major John B. Broadfoot, of Fayetteville, N. C., serves corn meal to order at any given time. Likewise old Sam Hudson and the Benders, of Pollokville, up Trent river, will serve an old-fashioned "boiled dinner" in an inimitable manner which few housekeepers can do at this age. Moreover, it is quite a trick to garnish a Christmas turkey with the very golden corn which lured him up to the blind where he lost his life when the hunter shot off his head. There is a host of sharpshooters and high grade angiers in that Cumberland countryPemberton, Holt, Littcloh, Morgan, Col. Mellett, and fifty others-who fish from clear water ponds and running streams which are rare down South, and eat plank shad and shuck oysters at their inimitable club houses by Cape Fear reservoirs and feeders. Rainbow trout and striped bass are common and heavy in that marvelous plateau of glaciology.

By the way, speaking of way back reminiscences, I may mention casually that my large Rand \& McNally railroad map, which embraced all the states of the period, is a net drag to observers who discover that each line of my peregrinations is marked red with my convenient pencil. It is the same on the Canadian Pacific early map. Both folders include coastwise and inland routes from ocean to ocean. I have added new trails each year. An active spider could hardly have spun his own web with more diligent tracery. Maps of the United States are not made nowadays as they used to be a half century ago. The scale of miles is different. One man cannot live all over the Western country at one time any more. A single sportsman may have suffered disappointment by the scarcity of birds which the * burning off the dry grass in springtime lias destroyed, or midsummer drouth driven off to more favored places; yet the whole West should not be condemned as barren of game. Doubtless game has disappeared by various causes from localities now populated where it once abounded; but, nevertheless, it exists in widespread abundance and in remarkable variety "all over"-if one can procure 
permits. The woods, grass, lakes, marshes, sloughs and streams are "full of it." Having gone through all of the states in my fuli-fledged maturity with the express purpose to spy out the land, every facility was afforded by the railroad and steamboat companies; but none of them has won the crown and glory of the grand old Pennsylvania Central, the great railway artery and vertebral spinebone of the United States, whose magnate now dwells installed in marble halls magnificent beyond ali comparisons. Finger posts at the main station in the great metropolis all point southward. When Presidents Scott and Boyd catered to my travels in the $70^{\circ} \mathrm{s}$, I shifted from north to south by seasons. At the present date there is a direct tendency toward the Rio Grande for gun shooters of all sorts. It is a great range for road runners, chacalaeas and blue quail, to say nothing of jack rabbits and burros. From El Paso to Matamoras, both sides of the river are blent with strange characteristics of mixed civilizations which have hitherto been little written about till now, when F. I. Madero, a well-known resident of the Mexican quarter in San Antonio (called Santone), Texas, has taken the lead of ambitious followers after fame. I know the country weil! Mestizos sell frijoles (free holders) and tamales in the plazas, and the whole country is everywhere slashed and creased with wet weather gullies, arroyos and barrancas. It is a rough region to chase foxes, rabbits and coyotes, and jump the washouts with bronchos. Even running hounds will turn somersaults by mistake.

My post-bellum intercourse with the South began in the fail of 1868. WVoods and swamps, which are impenetrable at other seasons, are available then to sportsmen and prospectors. I was fain to renew my acquaintances with survivors of the war. Shooting birds and animals are preferable to killing recruits. On my arrival at Savannah I picked up Dr. B. P. Myers, in charge of the hospital, and started for Green Island with Dave Adams and George and Sam Stiles to run wild cattle on the deserted plantations for meat and sport. Ycars afterwards Myers became post-surgeon at Honolulu, H. I., and now lives in retirement at Claremont, California. He gets good pastime at Santa Barbara, and further south, at National City, I have a bungalow of my own. Within a quarter of a mile I can pick up metals where the army camp stood during our Mexican War and each soldier pouncied his own corn for daily rations. But my reminiscences do not touch that section where I was or recently arrived. It was a frequent trip of mine to voyage the Chesapeake and Albermale Canal and Dismal Swamp on Capt. Tom Southgate's weekly steamboat when the yellow jasmines hung from the forest limbs which overreached the waterway, and rabbits were seen swining across with ears set like a sail boat. Aleck Hunter was a favorite companion of mine for thirty years, and we made our first trip, by permission, to Old Pam:ico Light, where ducks, swan and geese were plenty around the beaches and the Sounds, and Roanoke Island was better. Points, and blinds were at hand all around Manteo and Nag's Head, and when the tide was out swans dabbled on the flats out of rifle reach, and when a shot was fired above them, masses would rise like fleecy clouds above the horizon. Hunter is the most eminent of all sportsmen who have studied ornithology. He has filled wonderful volumes with

- birdl shot, written a relation of four years' service in the Civil WVar, and put in valuable service in the United States Land Office. Besides, he has given away his dress coat and keeps up a lively two-step clog dance at the time of his record.

Aleck Hunter wrote in March, 1908: "I can readily understand your giving away your dress coat, and eschewing suppers. That kind of pleasure I gave up when I was fifty years old. It was simply 'Ne vous ne jeu sas le Chandelle.' 
I studied years ago how to get all the good out of life without paying its penalty, and I think you did the same thing-for both of us are phenomenal in health and vigor. I have been a dutiful son of old Mother Nature, and the ancient lady has treated me tenderly." $\mathrm{He}$ is still diligent in the U. S. land office at the age of 66 .

On one of our trips abroad Capt. Southgate's steamer Newberne, which ran semi-monthiy between Norfolk and Newberne, N. C., via Washington, he introduced us to a venerable supervising inspector of steam vessels named Marshall Parks, who lived on Freemason street, Norfolk, Va. He must have been eighty years old then, and he died afterwards at ninety. He told us a story which modern men of business who stand on their record have never heard-how he and Cornelius Vanderbilt were partners away back on Albermarle Sound and undertaking to raise sweet potatoes, called "Harmon" (so named for the original producer), and ship them to the New York and Baltimore markets when dug. They owned a freighting vessel and were all ready to sail when a terribie storm came up and closed in the inlet and shut them out of their tide-water trucking business. As a shift Cornelius began running a large steam ferry from the New York battery to Staten Island, made big money, and not long after went into railroading. Somewhere about 1853 he got into possession of the New York Central and ordered the nurses and baby wagons out of St. John Park, built up the entire square with a freight depot and terminal down town, and warned the old knickerbockers to move up town. Rutherford Stuyvesant was included. He became a stockholder of Forest and Stream about twenty years afterwards. So did A. Augustus Low, the son of the great tea merchant; J. U. Gregory, of Quebec, and Oliver Optic, of Boston. This is an interesting fact to readers of my reminiscences.

Time was in the $70^{\prime}$ 's and $80^{\prime}$ 's up to 1885 when I was a good enough beilwether for sportsmen to follow when I gave any of them a cue, and tote them to a high mountain, like Moses was led aloft to survey the surrounding forest. There is no such a celectable elevation as Mt. Pisgah, which stands on George Vanderbilt's demesne among the Appalachians. 


\section{CHAPTER VI.}

\section{A SOJOLRN IN FLORL1)A.}

MEM., an index, tab or tally, serves as an excellent purpose if one undertakes to retrieve bygone years. Forty years ago seems short to me. Ore day carries me back instinctively to the time when I went gipsying. Although repeatedly interrupted by spasms of business activity and speculative ventures, my pursuits were reciprocally subordinated to each other. An active temperament tires a man of the monotony of a permanent tenable home. Well-to-do peopie are apt to travel. Consequently, when my only son of thirteen years was called by death on February 22, in 1869, I closed my residence in Brooklyn, N. Y., and skipped with my wife to a warmer climate, where nature smiles when mourners weep. Thence forward for the five years previous to my starting my "Forest and Stream" we were always moving about states, provinces and territories, and from one Indian reservation to another, and I would always locate her at available stopping places while I went prospecting.

In those fallow days, when sportsmanship was not a fine art, and the latest style of a shooting jacket alone gave a man the entry into exclusive clubs, we inevitably carried guns for protection, provender and pastime, depending upon them to keep the camp larder supplied. Hunting for the pot was entirely legitimate and an incident of the outing. Deer meat, squirrels, ducks and quail or any other game all went into the same stew at each meal. That was old moose hunter Warner A. Wilder's practice and mine in Muskoka or any other part of Canada.

In the spring of $1870 \mathrm{I}$ put in most of my time with Dr. Chas. J. Kenworthy, of Jacksonville, Fla., on the cruise of his catboat "Spray" from Cedar Keys to Punta Rassa; and later at the Indian river with Fred A. Ober. On the west gulf cormorants lined up like regiments of soldiers on the shores of the wooded isles at Cedar Keyes, and red cedar pencils were plenty. At Homosassa we found Greene Smith and wife, of Albany Journal, keeping a boarding house for sports who caught $2 j$ pounds of redfish in the river, interviewed a great alligator sunning on the river side, alert to slip into the water down his slide like an otter when alarmed. He was said to be seventeen feet in length. Grape fruit, the largest grown, on trees as great as were ever seen, were wonders on premises once occupied by Senator Yulee, before the Civil WVar, during which period he became Secretary of the Confederate Navy.

A tidy excursion steamer one day took us down to Jones' on Sarasota Bay. Coral reefs, channels and nigger heads were traversed all the way when the wind and weather were fair. When it stormed bird fliers were smashed against the glass of Egmont lighthouse by the dozen, and the keeper put in his spare time in taxidermy to set 'em up again. On the way to Tampa we met old John Gomez hauling his boat up the beach. He was a lively old skipper of 87 years of age, who lived until July 23, 1902. He was born in 1791 . His age is verified by the church registry at St. Augustine. He died at Tarpon Springs, Fla. He used to take sea anglers out fishing for big fish.

On the way to Cedar Keys we stopped off at Gainesville and slipped into Gulf Hamik, where cattle run wild, and found a party of sportsmen which had 
been attacked by a herd of them. A big bull ran one of the boys up a twenty-foot "paimetto," took the limber trunk between his horns, wagged his head, and tried to shake him out of the tree. His comrades, who heard his call for help, arrived just in time to scare the animal off. This immense wilderness runs parallel with the coast some sixty miles. The southern point is not far from Ocala, and a horseman used to carry a mail bag there from Homosassa. Matters are different now. There are more people in the vicinity and fewer ferocious cattle.

On my way east I took an excursion up the St. Johns river, called at Harriet Beecher's up stream, took a bath at Green Cove Spring, stopped off at Paiatka, where the Vermont Chas. F. Orvis' brother kept a winter resort, caught bass cpposite the house, ate oranges and bananas at Hart's orchard and plantation, heard a six-foot diamond rattlesnake sing at Mrs. Blonson's. I called at Will Fuller's beautiful place, located on a shell mound just above hers. His wealthy father and uncle were brewers of Brooklyn, N. Y., and James was the Master Mason of Commonwealth Lodge in 1857, when I was "made." He was one of the first orange growers from his section.

It was a delightful ride up river to Enterprise. Sanford and Lake Worth, passing between the patches of lettuce, blue hyacinths, green arrow-heads projecting from the water spaces frequented by snakes and alligators, so dense that the steamer could hardly push through them. At the Enterprise Hotel, on the lake side opposite Sanford, we had a six-foot alligator tied to a stake by a stout six-foot rope and set a big dog on it. The beast would hiss like a fighting cat, and when he swung his tail at the dog to floor him the snap of the rope threw him with a somersault. We did not like to have the scaly prisoner teased, but people would like to see the amusement.

I devoted the following summer to assisting President Fayette S. Giles and Lafayette Westbrook, state representative, to set th the notable Blooming Grove Park, securing Ezra Corneil, David Dudley Field, J. K. Morehead and others for directors of this superlative preserve in Pike county, Pennsylvania. Ira Tripp, of Scranton, gave us a pet black bear which future lady members fed with cake, ice cream and watermelon. Big Joe grew to eight feet tall when he stood on his hind feet at four years of age. One sunny day in midwinter, when the snow melted on the "knobs" and he thought spring had come, he slipped his collar in this hillside den, went up to the club house to see the place, and the temporary care-taker poked his rifle through the blinds and killed him on the veranda. To mention the historical incidents of its forty years' lifetime and name its notabie club members, would fill a readable volume of interest, such as the versatile and veritable Fred. E. Pond-of "Turf, Field and Farm"-furnished to the public twenty odd years ago. There is much to his record as well as to mine.

As the winter months passed on to spring, I turned to East Florida and crossed over from Tocoi to St. Augustine on Judge Wilmot's improvised wooden railroad. He was an enterprising man of the highest sort. He was able to give the moving public comfortably quịck transit just after the Civil War ended, when the South was so miserabie that no one had a dollar or credit after the long struggle. Its entire rolling stock was essentially home-made. I penciled off a sketch of it at the time.

The tracks had no iron straps and the road no bed. There were neither freight nor passenger cars per se, taxonomically speaking, but the carriages were a droll combination of the flatcar and the old-fashioned Concord coach, each one seating twice three persons, vis-a-vis, inside. Baggage and freight, if there happened 
to be any, were both carried outside on either extremity of the projecting platform. and if inside space were by chance overcrowded, the trunks and boxes afforded convenient sittings for tourists who were fond of forest scenery and a quiet smoke in the open air. In that respect the improvised vehicles resembled the modern observation cars, though outriders were wholly unprotected from sun or rain. It usually occupied three hours to make the run of fifteen miles across the neck from the St. Johns river to the ocean. When special dispatch was demanded an old white horse was substituted to run as express. He would make the transit in two hours and a half. Of course, the train went light at such times. The Tocoi railroad was the first railroad in Florida. It existed before the war. Without such a railroad St. Augustine was practically isolated. The land between it and the river was virtually a swamp, in many places without a bottom, and a tramway was much cheaper and more easily constructed than a wagon road of dirt. No vestige of the old plant remains.

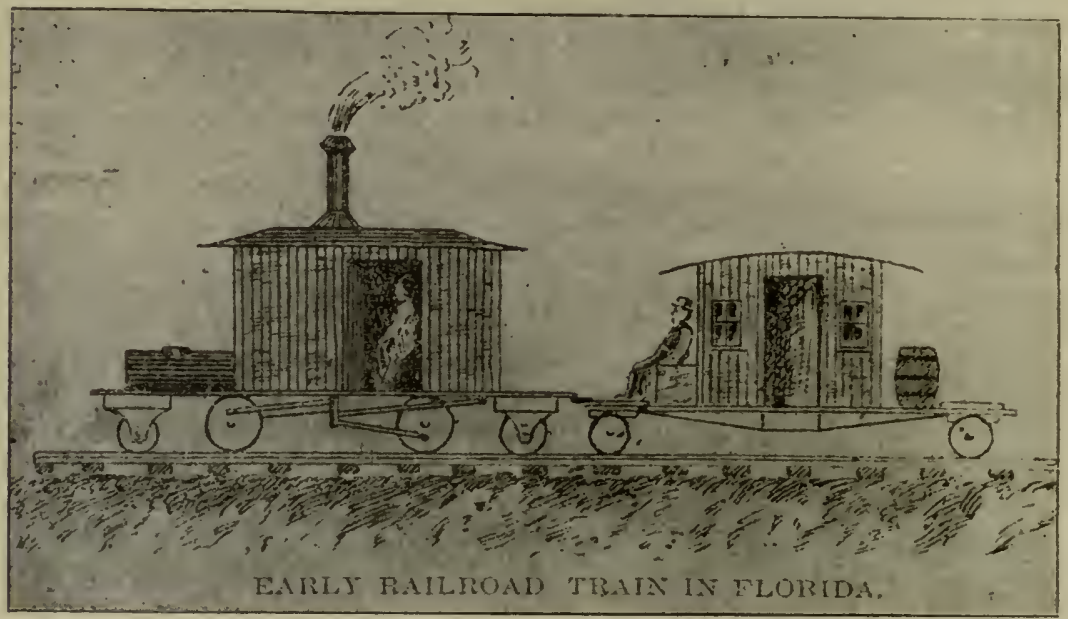

The next fall I found the persistent canoe man, N. H. Bishop, on the Indian river with Fred A. Ober. Both were naturalists. One was especiaily in quest of fancy feather birds of all colors along the shore and among the swamps and timber, and up the Oclawaha, including snake birds (plotar anhinge), with a neck longer than its body, which could swim better than they could fly. When a small excursion steamer carried tourists up stream at night with a fire power on the bow to help shove the boat around the bends, lots of native birds would be scared off their roosts from the overhanging branches when the flashlight passed underneath "chugging." It was an exciting scatteration. Ober had a wiry working partner with him named Jim Russell, who was a keen ailigator hunter for their hides. One time he dove to the bottom of a lagcon and knifed one which had sounded. The trio were exploring the everglades, and about this time shoved their houseboat four miles up the Kissimee-choked morass waist deep, with alligators and snakes all around them, to say nothing of swarming mosquitoes, red bugs and tormenting insects innumerable. His object was to find the Okechobee once more after the Seminole War closed in 1838 . He was the first 
white explorer who had penetrated since, and the whole covert was virtually an incognito, except to veterans like my venerable friend, Major Hamilton Merriil, who followed on to my "Forest and Stream" office in 1873. He died about 86 years of age and his surviving son is getting old fast, too. He was prominent at Albany. N. Y., for years. His father chipped in with the rest of us to complete our "Camplife in Florida" in 1876, and old man Samuel Clarke, of Newton, Mass.; $\mathrm{W} \mathrm{W}$. H. Gregg, of St. Louis, and C. J. Kenworthy, of Jacksonville, filled in the correct ornithology for the composite book and told us where to catch the best fish. Old man Gregg must be 80 now all right, but he still sails his "Odion," and has invited Barton Evermann, myself and Tarleton Bean to beat the November gales to Key West every year the past few winters. Meanwhile his son-in-law is president of the Canadian Pacific railroad to the Rupert terminus.

I might have much to say of Fred. A. Ober ("Fred. Beverly"). No worker and producer is more worthy of honor and eminence. But he is not in quest of a niche or pedestal, or to be hung in a gallery.

Mr. Ober may be said to have made his debut through "Forest and Stream," which becante his earnest patron and promoter at the outset of his career; and its quondam editor, who writes these lines, delights to do him honor in his own peculiar, rough bon hommie.

In $1876 \mathrm{Mr}$. Ober had charge of the "Hunter's Camp" at the Centennial Exposition in Philadelphia, a most attractive exhibit in Lansdowne Ravine, where he figured conspicuously as a veritable Leather-Stocking in backwoods costume, his swarthy locks aiding very materialiy to embellish the character which was not all assumed.

After the West Iridies and South America,--as far as the mouth of the Orinoco,-came the several extensive tours of Mexico, beginning in 1881. In the course of one of his cross-country trips, in 1883, he traveled 10,300 Mexican miles, and climbed to the summit of the Popocatapet1, 17,800 feet upward. When Ober cannot delve he will soar! 


\section{CHAPTER VII.}

THE WILV WEST.

ROAMING at large among the states and territories during the 70 's the shifting seasons were followed year after year without any special purpose on my part, winning or losing, accepting nature's gifts and taking chances wherever I pitched a camp or drove a stake, north or south, or elsewhere. Yet among the wild Indians in our reservations there was risk when buffaloes were running, and really trouble moreover was at hand. Army posts were distributed all over the prairies, and I frequently dropped in to report when a storm threatened. I stopped in at Fort Custer ten weeks one year with Senior Captain Sanderson, 11th Infantry, by invitation, with my wife along. But that was in 1881, after the war was fought, and all over redskins were subdued and made captives. Meanwhile I cut across country.

Whatever happened at large is but an echo and an imitation of history, which extended from 1804 to about 1860 under the reign of the explorers, Lewis and Clarke.

Yon see the brecch clout Indian vanished as soon as the freighters and traders enabled them to be called blanket Indians. After the buffalo slaughter was ordered in 1875 they adopted felt hats. I saw lots of old felt hats in the Sioux camp at Littie Big Horn, where the departing warriors, after the Custer massacre, left their lodge poles standing and empty kettles on the ground. I was at Chetopah, on the Kansas line of Indian territory, when some of the buffalo hunters fitted out with splendid mounts and a grand flourish to deplete the redskins' larder by government edict, and I was on the Yellowstone in 1881, following the winter when the last wholesale slaughter of the buffalo and antelope took place in the deep snow aiong the bottom. The string of carcasses as I saw them (all the antelopes and most of the old buffaloes remaining "unpeeled") was at least one hundred miles long, sometimes in clusters just as they were shot in their tracks, with intervals of mesa between, and again in single file or by twos and threes, for rods together. It was a gruesome sight, for the wolves had exposed the bones of all whose skins had been taken by eating off the meat. There were no hungry wolves that year. Not a howl was heard.

The year previous, in 1874, Congressman Fort, of Illinois, had introduced a bill to protect the buffaioes, but those whose business was to fight the Indians had already decided that the least dangerous, least expensive and most expeditious method was to destroy their rations and wipe ont their subsistence. Knowing the game that was on the Indians fought desperately at the Little Big Horn, and all along the navigable rivers in Montana the steamboat men had to ironclad their pilot houses to protect their river men from marauders on the cliff. The sagacious Crows were then quite willing to cede the right of way to the Northern Pacific railroad in 1881 , whereby they might receive food to supply the lack of buffalo meat.

Referring to the action and display of buffalo and antelope afield on the Arkansas in the 70 's, Dr. A. J. Woodcock writes poetically: 


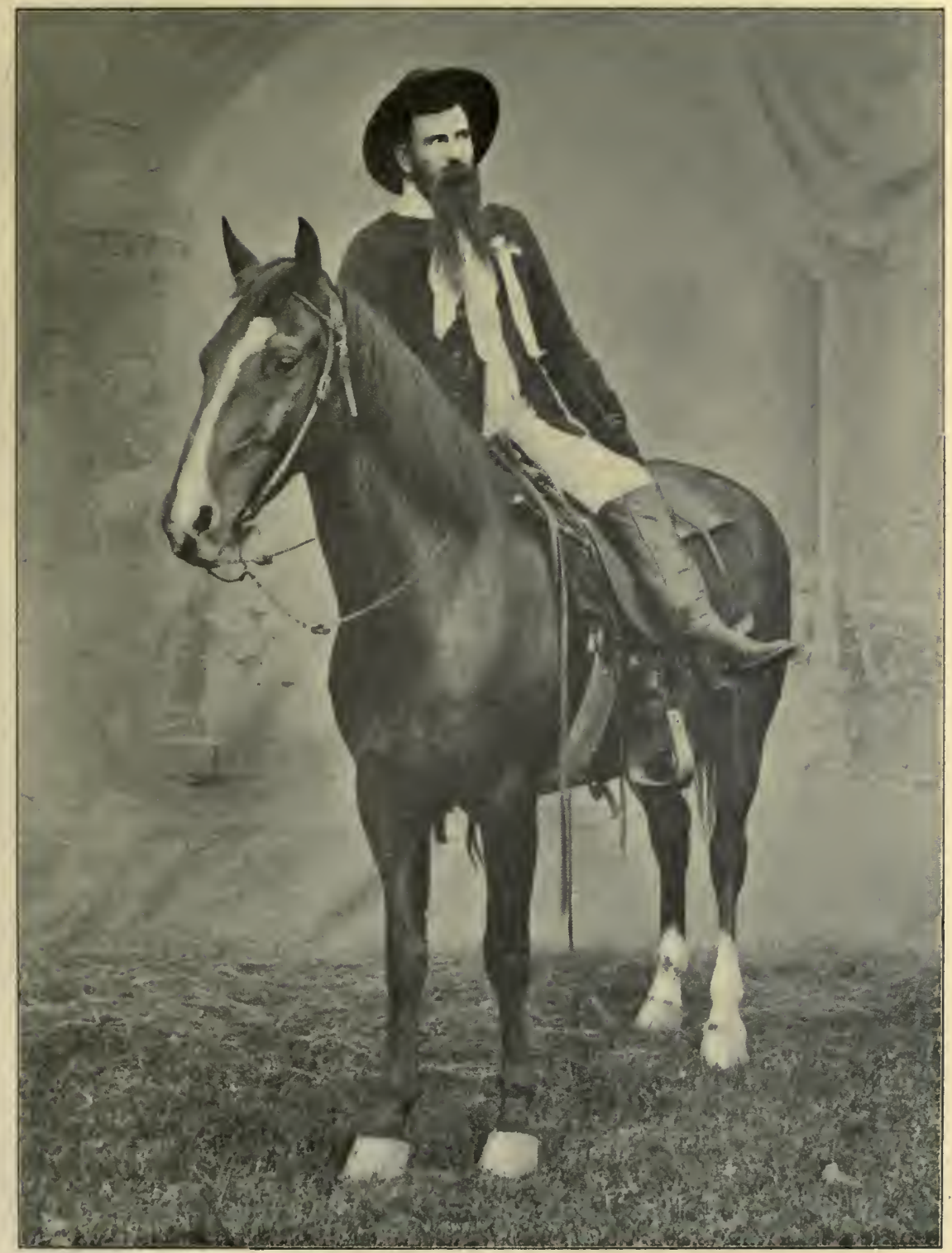

DR. A. J. WOODCOCK. 

"Yes, far back from the river, in places the buffalo grass stood one foot in height, while the luxuriant growth of grass in the river bottoms at times in places almost hid the Arkansas from view; in almost every piains visited the prairie zunners, as the Indians called the antelope, added life, the very poetry of all motion to the view; the lesser prairie folk that fly, run and crawl were most abundant and seemed to think that the beautiful prairie lands bordering the river were made for them, while the scattered groves of cottonwood trees assured the prairie traveler of abundance of wood for his campfire, and that everywhere in those reaches of the river that were bare of trees, ready to hand, was the "bois de vache,' the buffalo chip-it was borne in upon one that the materials of a good camp, wood, water and grass, as stated above, were ready to hand, which with the plethora of game and the dryness of these sandy meadows bordering the Arkansas, especiaily when the prairie lands were a dreary wilderness of mud, of a verity made them seem to the old plains wanderers what in fact they were * * * most hospitab!e.

"Yours to the end of the trail,

"Dr. A. J. Woodcock."

The doctor calls special consideration to the fine writings of the late notable sportsmen, Col. Geo. D. Alexander and Wm. C. Kennerly, who wrote for the outdoor press and rature over the name of "Old Dominion," where the latter harked the wide-awake foxhounds most around Fairfax section. He says: "I have both of them in my studio in pen and photo, afoot and mounted, and many an English lord and earl, the Atlantic sea across." His briliant pen never rests while in action. And he quotes from Kennerly in this way: "I have been touched by Dr. Woodcock's personal allusion to myself because, presumptuously, I thought that I could distinguish some similitude between Colonel George D. Alexander and myself. We are about the same age-eighty-three or eighty-four years old-both have been Confederate soldiers, both devoted sportsmen, and better than all, both chock fuil of good, ricl, red Scotch blood, and the same with regard to our friend, Colonel Gordon ('Pious Jeems'), of Mississippi, for I believe that we are all three nearly allied blood kin." Gen. Wade Hampton is included among his comrades, and I have been his associate repeatedly at Sapphire, Toxaway, in Transylvania, N. C., of recent years. I think he died some five years ago in his eightieth year at Highiands, S. C.

The October issue of Field and Stream, for 1908, has an article of mine which starts with a duck hunt in Wake county, North Carolina, and ends with the capture of a noted "moonshiner." The incidents are quite different from ordinary. And this puts me in mind of a seven-weeks' scout I had with Major Jacob Wagner, U. S. A., in 1878, among the mountain ranges of Matanga and Ashe, in North Carolina, Johnson county, Tennessee, and Scott, in Virginia. We pulled a lot of illicit stills during the outing, and when I drew out of the scrimmage I left the field for Aberdeen Courthouse, Va., in company with Marshal Kyle (who was afterward's killed), each riding double with a culprit up behind. To say that I feit out of place is a sore confession, for my sympathies were with the men who could not earn a dollar (each) in any other way while they dwelt in the mountains, where ingress and egress in those days was not possible except by a half-barred sled hauled over a trail. Even the streams afforded us exit. We could wade out that way. Anderson, son of C. Bird Jenkins (seabird), showed us where the best trout fishing was, and took us straight to his still and treated us to corn whisky. It broke my heart to be caught in company with the revenue officers and at once be suspected as a decoy by the man they snapped. It was a surprise party to me, and $I$ quit the business at the first leave. 
That same year I had an upset at Pig's Eye Bar, just below St. Paul, to pay for it. My friend, D. C. Estcs, a naturalist, started in his own sailboat for a voyage down the river to Lake City, camping out and shooting July woodcock by the way. Our outfit was compiete in every particular, and a grand time was anticipated, but disappointment soon came, for when about one mile below town a flaw of wind jumped the high eliff and struck the sail, and the boat at once went over in mid river and in deep water. Numerous bundles, carpet-bags, guns, rods, blankets, tents, in fact everything, was either set afloat or sent to the bottom. Being a good swimmer, I set out boldly in boots and corduroys for land, while the doctor, to save the boat from going down stream and himself from going to the bottom, stuck to the craft, and setting himself astride of the capsized boat, succeeded, after about one hour's hard paddling, in reaching the shore. The boat, as soon as possible, was righted and bailed out, and gave chase to the floating bundles and valises, but before they could be reached all had sunk but one of little consequence. Two valuable guns, a great quantity of tackle of every description, composing the outfit; all the clothing, money and other valuables were lost. Fifteen hundred dollars would hardly cover the loss.

I recall my numerous friends among the shooting clubs at Price Lake and round about: Timberlake, Seabury, Zimmerman, E. F. Warner, R. W. Mathews, Geo. R. Finch.

At the traps I used to average three to five birds out of ten, but my comrades expected better things.

The best field work I ever did was among the July woodcock in the cornbrake of Bay City, Mich. A companion sportsman and I walked down parallel rows, one shooting to the -right and the other to the left, so as not to hit each other. -The dog took the center to flush the birds. We bagged a dozen fine ones and took them to the hotel. The cook burned them to a crisp. Blackbirds used to fock by millions in North Dakota during the grain harvest. They would rise in a cloud so dense as to obscure the sun. I fired two barrels into the mass and dropped fifty-seven killed and wounded. Geese in the fields were better game. Coming home at dark after a successful hunt in the Gereaux Slough back of Pembina in September I shot at a blue wing teal over my head and dropped him. As he fell a barred owl dove for him at the flashlight out of the dark and I got him with my second barrel.

Once on the Yellowstone, near Pryor's Creek, I climbed the top of a bluff, and peering over the edge of the bank rested my gun on the sod where a bevy of sage hens were going through a minuet, and dropped seven, one after another, until I had killed the most of them. The fool hens couldn't guess what struck them, and the noise of the gun did not scare them. Talk about pot-hunting, I was right in it. I strapped the heads into the bights of as many leather whangs which were tied to my saddie and started down to the bottom among the plums and cottonwoods. Lieutenant Fuller, a soldier from Fort Custer, took one side of the timber belt and I the other, looking for bush deer. Returning I ran up against a big grizzly which had ridden down a plum tree between his legs and was busy pulling the plums off a branch by the armsfull. He had the stem of the tree under him between his hind legs and the branches close to his face. He looked at me for an instant, and regardless continued his repast. I concluded not to meddle with him and rode out of the timber. When I reached the mesa $I$ found just one chicken head in its ioop. In my intervicw with Ephraim I forgot about the dead birds at my saddle bow. 
I have knocked about the state of Kansas a good deal during the 70 's-among the sunflowers, grasshoppers and tumble weeds. Old John Swainson, of St. Paul, and I had to carry a box of ice with us when lunting prairie chickens one hot September to put on the top of his red setter's head to keep him sane. The simoon wind was so buruing that we had to get behind a wheat stack to keep from being fanned. The same old dog was caught up by a straight tornado at the town of Hallock, Minn., in 1880, which jerked and whirled him over and over an eighth of a mile over the prairie while fast to his kennel. When rescued after the blow was over, he ran under our bed and staid there for twenty-four hours, trembling. As to Kansas, our famous bird shooter, A. C. Waddell, writes me a recent letter from New Jersey, which happens to chip in a most interesting opinion on that section, which I append right here. He says:

"I spent almost twenty years in Kansas and Kansas City, Mo. What a life of pleasure interspersed with trouble I had. Dr. Nicholas Rowe, of the American Field, remarked to a gentleman in San Francisco once: "That man (meaning me) would have been a very wealthy man had he used the same energy in mercantile business as he has in sportsmanship, but he loved the occupation: of the sportsman witl his dogs afield and he has devoted all his life to hunting. and fishing.' I do not regret it. I am 75 years old May 25 coming-hair black, and they say as well preserved as any man they ever knew. I owe it all to outdoor exercise and in the saddle. I am now cooped up for want of opportunity to be in a game: country: I want to be in the field., I saw Charles H. Raymond not-long since-fat and content with wealth. He bought dogs" and gave large prices.

"The pioneers of sportsmanship are the ones who had the real sport. What a field Kansas presented to those who traveled over the old Santa Fe trail during the years from 1868 to 1876 -great prairies over which the deep ruts made by the prairie schooners, years before appeared-covered with grass,' with here and there wild sunflowers and the endless variety of prairie flowers. To be in such a field with dog and gun and to see the rise of the prairie chickens as, they sailed a way before you-what a life to live and what a life to think back over.

"I have no fault to find and I thank my God that he so directed my course of life that it led me to pleasant places. I have been to and over all the Kansas rivers and creeks." Most every farmer in Kansas knew me. I camped on their farms and was ever welcome, for I returned favors. From Kansas I went to California, lived there six years, was familiar with all sections of the state. After that, in 1895 , I moved to Mississippi and remained there five years, all this time accompanied by the finest lot of setters and pointers the North could produce. Six years, ago I returned to my birthplace-by invitation-to live out the few remaining years that I may have, and it is pleasant, very pleasant, to be in commuinication with Chas. Hallock.

"Your frientd ever, is : : "A. C. W ADDELLL." 


\section{CHAPTER IIII.}

\section{LITERARY WORK AND TRAYEL.}

WHEN the great moral uplift in out-of-door recreation began to be felt, some forty years ago, the title selected for its mouthpiece by its accredited leader, Arnold Burges, was "The American Sportsman." But this did not fully express the peculiar sharacter of pastime which nature affords in her simplicity and attractiveness. So "Forest and Stream" was substituted as a catch word, and all the gunners and anglers said "Amen!" I took the lead of its 600 subscribers and was in personal touch and step with them. All celebrities, army officers, explorers, scientists, Indian missionaries, plainsmen, mounted police, seafarers and wayfarers, Canadians and neighbors from across the international line, a famous galaxyno man can remember his acquaintances-but whose brightness may now be made to reappear in remembrance, and they followed to learn the way to choice shooting grounds, where I had beaten the bush in years before. Chas. Reynolds, just from college, prepared the guide which I had compiled.

They were good worthies whose acquaintances I had made while I worked up my "Fishing Tourist" in 1873. I then had twenty-five years of travel with rod and gun to my credit. Governor Horatio Seymour, of New York, headed that list and put up fifteen dollars as a three-years' subscription. He banked on its long life, and it has lived thirty-eight years. Geo. Bird Grinnell, who accepted "Forest and Stream" from my hands as chief when I dropped its management, has been a wonderful sportsman ever since among the Blackfeet and herds and heads of Wyoming. Previous to that he was with the government explorer, F. C. Hayden, in 1874. He stocked up on natural history and wild Indians then, and has published valuable books innumerabie.

I had devoted the summers of 1870-3 to canvassing members for Blooming Grove Park Association, with headquarters at No. 111 Fulton street, New York, picking whortleberries, putting up a club house on Lake Giles, and roping deer which swam across the water to elude the chase of the hounds, so as to put them in our wire paddock as a game preserve. Our warden, Ed Quick, was not slow to keep them from poachers, and Capt. Cassell, of Baltimore Druid Park, and Col. Clark, of Tennessee, gave us many-200 head-from their surplus.

In 1870 Charies Dickens touched my elbow at Westminster Hotel, in Irving Place, while in company with Fayette S. Giles, nineteen years before he wrote up his American Notes on the Red River in Louisiana. In 1858 I met ex-Senator Henry M. Rice, of Minnesota, when he was one of three Indian Commissioners. He was on his way up to Leech lake and had to stop over night with his friend at the old $\log$ hostelry of Mrs. MrCarty, on the edge of Wisconsin. She charged fifty cents each meal and 50 cents for a lodging. The transients asked "for baked potatoes and boiled eggs, or something you don't handle with your hands." It was early dark morning, and the room was lighted with an only candle. She carried an axe in her hand as she was passing from the woodpile to replenish the fire, and she replied: "Ate yer breakfast, or I'll give ye the contents of this axe." And she was reported as having killed a female helper in the same way. In 18i1, on my return from the great lakes of the West, I was given a seat next to Lord Dufferin, 


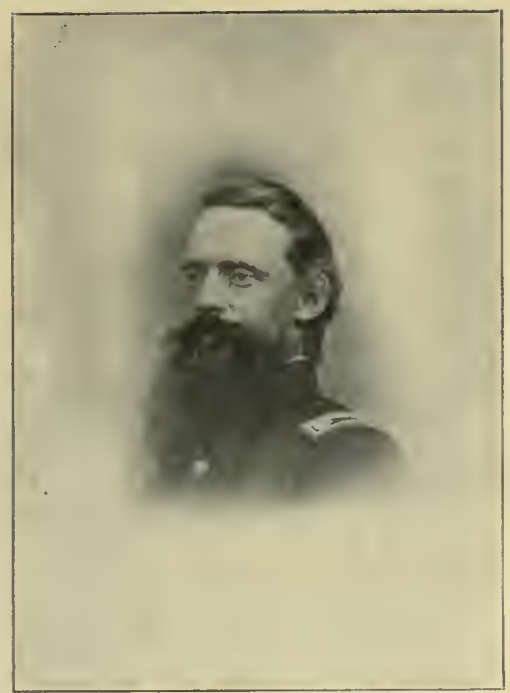

COL. A. EGBERT,

Contributor to "Forest and Stream."

in

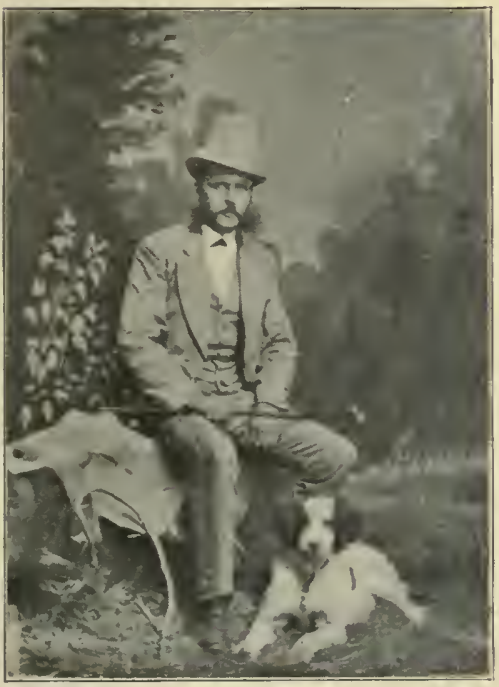

MR. ED H. HOPE, Well-known Dog Trainer.

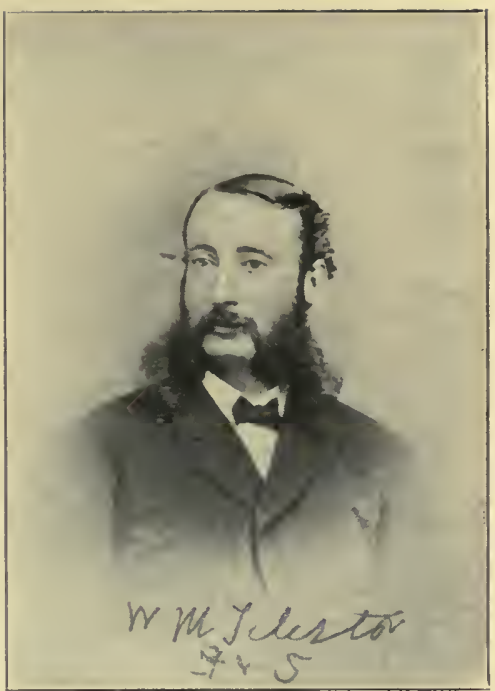

MR. IV. M. TILESTON, Associate Editor.

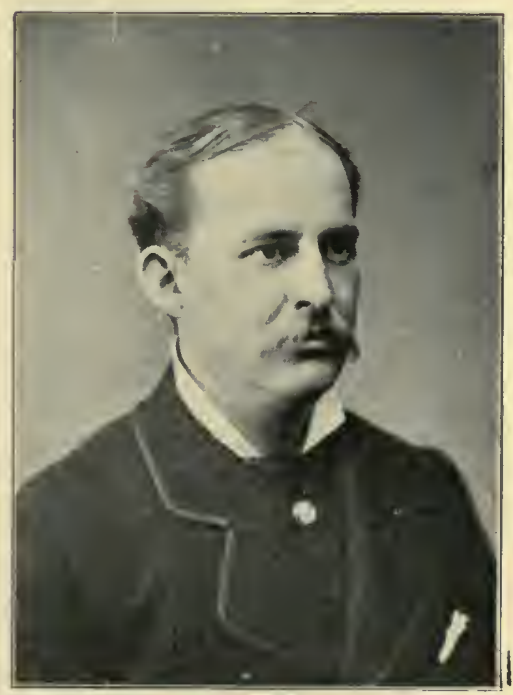

MR. A, N. CHENEY, Popular Writer on Angling. 

the author of "High Latitudes," at Fred Cumberland's banquet at the Rossin House in Toronto. Then Dr. James H. Richardson, who was present, prepared for myself and wife a special trip to the Upper Ottawa country for a few days' fishing in the mountain lakes about Des Joachim, and I have his letter before me, dated Toronto, July 12, 1875. Yeis see, readers, that my portfolio and pigeon holes are crammed with uncalendared tales to print. With changing seasons I was wont to change my trips from state to state and latitude to longitude. All this time my staff was serving as recording angels-William C. Harris, Barnett Philips, Wm. M. Tileston, G. M. Taylor and Horace Smith, besides Reynolds and Grinnell. Poor Tileston was killed by a wall faling on him and young Webb, while the Westminster dog show was going on. It was a sad accident. My office desk kept me fully eight months. Four months chiefly engaged me annually at the South.

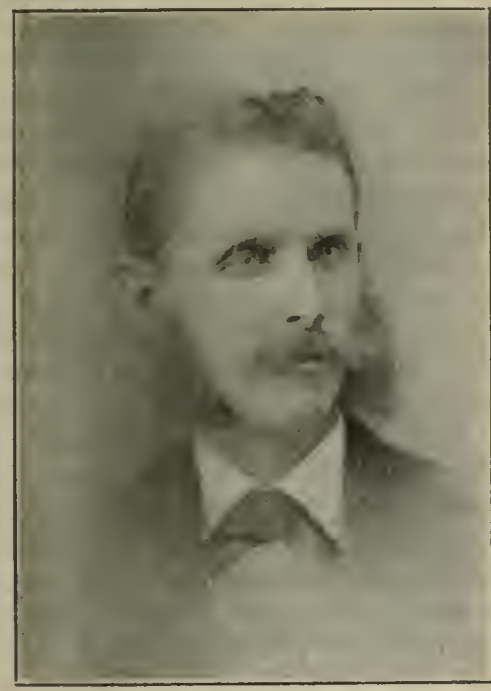

MR. FAYETTE S. GILES,

Secrelary Blooming Grove Park Issociation.

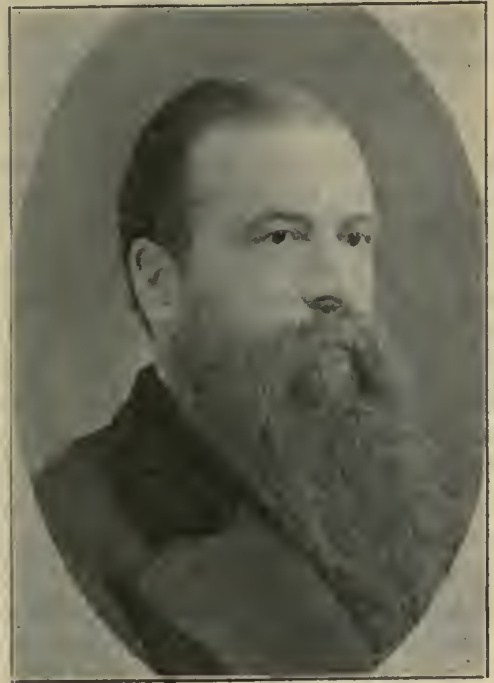

MR. H. H. THOMPSON, Angler and Angling Writer.

I went to Menchan, Rigolet and Ponchartrain with C. G. Ballejo, the best of southern bass anglers. At Port Aransas, Texas, which swarms with ponies, ducks and tarpon, my business man, Wn. C. Harris, used to take Perie with him to paint fish he caught for his forthcoming illuminated "fish book." He died some four years ago at 74 . The sporting ground was quiet when I dragged a trailing spoon or squid; but nowadays, when the government has taken hold on the premises for special uses, the boats which start for the fishing ground string out in a dozen trailers, as they have done for haif a century at Alexandria Bay, where I caught my heavy muscalonge among the St. Lawrence Islands while housed at Crossman House. There are even better fish around the North Carolina sounds and inlets-much better house boats congregate. While our friend, Washington A. Coster, hunts for deer and prods hibernated alligators out of their mud holes in quest of salmon, I resort to the cold streams of my long life friends, W. H. Woodward, of Birmingham. Ala.; Ivers W. Adams, of Boston, and the late lamented General Surgeon Baxter, of the U. S. Army, whose mansion on the Restigouche 
was an attractive resort for special guests, where high-grade fish portraits were painted wonderfuliy and true to life by his dexterous wife. I had hoped to have his Indian birch canoe and his appearance in dress uniform be shown in this selfchapter; but it will doubtless come in a future de luxe volume. His summer house was burned fifteen years ago, and now the entire Campbellton population of 2,000 was burned last year, bodily and totally.

In 1874-5 there went forth an edict from the government, sub rosa, to cut off subsistence of the plains Indians by slaughtering buffaloes, elk and antelope. In consequence the wolves starved as well as the redskins, but of late years they have fared much better, where they can fatten on the homesteads of the spreading settlers.

Once, away back, when Fred E. Pond was hunting prairie chickens in Wisconsin, he held up a train for five minutes, on which I was traveling, and obtained a momentary interview with me. Then he waved a signal and the train moved on. He was just of age, and good stuff.

In Canada the French (habitans) and half-breed guides and voyageures were very tractable and serviceable, and drank whisky "only when I did" by agreement. But let the redskins appear in a later chapter. I will introduce a lot of them whom I met. I have a list of a hundred or more; and also a list of my army comrades, who ranged the plains over and wrote up essays for "Forest and Stream." I missed few frontier posts from boundary to boundary, north to south, Maine to Texas, and Pembina to Caddo in the Nation. I spent ten weeks with my wife at Fort Custer, in Montana, with Senior Capt. G. K. Sanderson, of the 11th Infantry, and Capt. Hamilton. of the Cavalry. We went out shooting and trout fishing in Big and Little Horm, Lodger's creek, Biack canyon and up the Yellowstone. Trout fishing and grayling everywhere. Old man Finkley, on Prior's creek, showed us the best fishing places. That was in 1881 , not so very long after General Custer's soldiers were wiped out by the Sioux (in 1876), and our river boat pilot houses were sheathed with iron plates to keep off bullets from the overlooking plateau, where Indians would ambush and shoot at us as we passed. We had some good shooting of our own-at geese-on the mud flats in midstream as our stern-wheel burrow chugged up the quick water. That same year I stopped with Major E. B. Kirk at Bismarck for a day, when they brought in Sitting Bull as a prisoner from Fort Yates below. At Terry's Landing, on the Big Horn, there was a covered way from the cantonment to the river side, where the soldiers went for water, to keep from being shot by the Sioux, who were still on the warpath. I put up with Lientenant Wheeler. The same year General Phil Sheridan was in the Rockies with the dukes hunting grizzlies, when G. O. Shields (magazine writer) joined the outfit at Ft. Custer and afterwards published a volume of the battle and exploits, with photos of pelts and trophies won. Captain Partello wrote up many hunting stories for the "American Field," and so did Lieutenant Schwatka. Such men are worth mentioning.

In course of time I worked my way eastward as far as Fargo, N. Dak., about October 1, and found Editor Hull, of the "Republican," whom I had known at Presque Isle, Maine, in 1859, where he was editor of the "Pioneer." Here is what he printed about my western trip. Every resident was interested; it was a critical time:

"He says that the buffaloes are running between the Missouri and the Yellowstone. He saw the first buffalo about fifteen miles east of Fort Custer, and while standing in the door of the stage ranch was fortunate enough to shoot one. The. herd.commenced moving southward about the middle of August, and two 
were killed on the 15th of August within fifteen miles of Glendive. They are most numerous between the Dry Fork of the Missouri and the Yellowstone, at a point about thirty miles west of Keogh. The Crows, Cheyennes, and many white hunters are in full pursuit, killing and skinning these animals at the rate of 150 a day. The herd is now crossing the Yellowstone into the Crow reservation; it may be for the last time, provided the Northern Pacific railroad gets through there before another year rolls around. Mr. Hallock says that there are about ten hunters, red and white, to one buffalo, and the race of the American bison is almost run.

Several parties of gentlemen have been, and some of them still are, hunting in the Big Horn mountains, all of them without exception fittcd out at Fort Custer. A. M. Jameson, an Irish gentleman from Dublin, has been in the mountains for five weeks, and in that time has killed twenty-nine grizzly bears. Count Andrassy, a lieutenant in the Austrian service and a grandson of Count Andrassy, the statesman, with a party of five other gentlemen. have also had good success in capturing grizzlies, as well as numerous deer and other game.

Jas. Lillidale, Esq., and wife, and Otho Shaw, brother of Vero Shaw, the well-known dog fancier, and author of several treatises on the canine race, are now in the mountains. Their sport, however, was temporarily interrupted by a stampede of the pack mules, every one of which ran back to Custer and had to be recovered before they could pursue their sport.

G. O. Shields, Esq., correspondent of the "American Field," of Chicago, and Mr. Huffman, the photographer of Miles City, with an outfit, had just returned from a trip to the mountains when Mr. Hallock left Custer, after seventeen days' absence, during which they had captured a good many photographs, some grizzlies and other game.

Mr. Hallock himseif has traveled five hundred and fifty miles by wagon and saddle, engaged in several hunting expeditions, outfitted at Custer, where he was a guest, and among other experiences was present at the council at the Crow agency for the purpose of securing the right of way through the Crow reservation for the N. P. R. R. He has carefully looked the country over with especial reference to the interests of the N. P. R. R. Co., reaching the extreme western end of the western survey, and will write a series of letters for the New York "Herald," which we feel sure may be depended upon as an accurate and interesting account of the country, its attractions and resources. Mr. Hallock took the first train in from the end of the track at O'Fallon's creek, Mrs. Hallock being the first lady passenger on the new extension.

Mr. Hallock says that from Fort Custer, north to Stillwater, a distance of about one hundred miles, there are many settlers, and on some portions of the bottom, where there is plenty of wood and water, one is hardly out of sight of fences for twenty miles on a stretch."

In $1882 \mathrm{I}$. was up Regina, Sascatchewan territory, near the terminus of the new Canadian Pacific R. R., and a string of Red river carts brought in sacks of pemmican for sale. That was the very last buffalo meat ever made into pemmican south of the Peace river.

Some considerable time afterwards, I think' it was in 1885 , I got an order from $\mathrm{IVm}$. 'T. Hornaday. (then of the Snithsonian) to put him on some fine game. But all we could find was haif a dozen dingy old bulls in Montana dusting themselves on the top of a mound. They were tearing their hair from grief.

To hark back quite a bit." After the rifle match was won at Creedmoor, Brooklyn, N. Y., between the Irish and Americains, with Major Arthur B. Leach and 
General Geo. IV. Wingate in their respective command of elevens, I took five of the Irish team down to the Nation (Indian Territory then, but now Oklahoma, and the rest of the world), and picked up a good manager, George H. Dorman, at Hannibal, on the Missouri, and a couple of good guides at Chetopah, on the Kansas line, and started for Cabin creek with Capt. Case and Bill Orme after deer. We had been sidetracked from the "M. K. and T." at Shell City. Mo., after quail and sage hens and others. We stopped over with Mr. O. Duck, but market gunners were not after him. John Rigby, the Dublin gun maker, and Joe Milner, the home stretcher at the 1,000-yard target, are now the only survivors of that party of thirteen, at 75 and 80 years of age. While we waited two days at Chetopah a painted gang of Cherokees rode into town and shot up the saloons at the railway station, and made all passengers in the waiting room kneel down and say their prayers. My riflemen from old Ireland galloped down from the town and ran them off quick. While we were hunting deer among the swales of the rolling prairie a big buck was hit, which ran two miles at least before he fell, and although the hunters followed him on horseback, the buzzards had his eyes and entrails out before they could reach him. They actually began to tear him while he was yet alive. The carcass was black with the birds when the hunters came up; and the air was filled with hundred's, and more constantly arriving from all directions, although up to the moment of the fatal shot two or three only could be seen aloft lazily quartering the sky. Perhaps the most mysterious feature of the whole occurrence was that the birds should detect the predicament of the deer the instant he was fatally wounded, and so follow him to the death; and not oniy the two or three birds of the vicinity, but the hundreds farther off and remote, who must have either observed the deer from their distant points of view, or else noted the unusual stir and direction of flight of their fellow buzzards. In either case, the evidence is specially conclusive that they were keenly on the alert, and that nothing within their scope of vision, however trifling, escaped their notice.

By this time the frontier army posts and forts were beginning to fill up with Indian captives, and down at Fort Sill Interpreter Jones gave me a large number of Comanche photos, which I sold to the U. S. Government-since 1900-for James Mooney to use in writing up the wild Indians as they were. I have a coupie of large Prang's lithographs in glass and gilt frames in the ethnological gallery of our new U. S. Museum, which shows two old trappers of the plains on horseback covering their packs of furs from being captured by ten mounted Indians who try to stampede their horses by shaking blankets, yelling and letting arrows fly. They had no guns in those days and the trappers stood them off with their rifles. In 1877 Capt. R. R. Pratt and Interpreter G. F. Fox had Crazy Horse and his family and some seventy Southwest Apaches and Comanches at Ft. Marion, St. Augustine, in uniform. The smallest Indian, at the tail of the line, was named "Matches," and he was a smart, cheerful match for any of them. He gave a little by-play in the plaza and could shoot arrows and keep six in the air at once by quick dexterity. My venturing among the wild redskins in the reservations was a hazard in the seventies. But I could enjoy the association of Micmacs, Malicetes and Mohawks at random in Canada, who furnished good voyageurs and bois du coureurs for salmon fishers and moose hunters. While sitting in my office in New York my first year Dr. W. F. Carver dropped in fresh from Dakota, where he was born, and shot an Indian arrow into my ceiling overhead to show me how he could shoot a buffalo through the heart on a run. Soon after he and $\mathrm{A}$. $\mathrm{H}_{6}$ Bogardus had some by-play before the public, shooting glass balls, and Buffalo Bill put up his first big show at Evastina, Staten Island. Those were great events. 


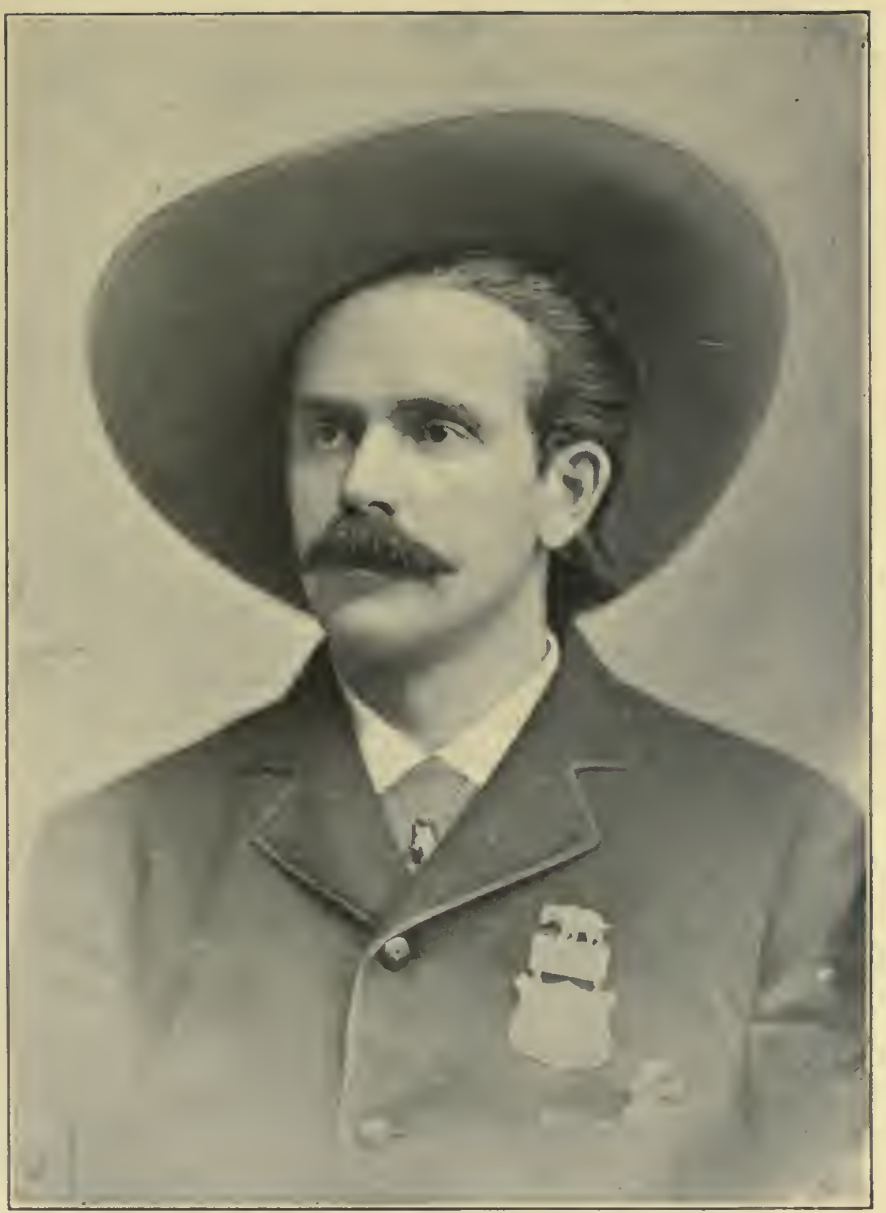

DR. W. F. CARVER. 

A little before that I was up at St. Regis lake, in the Adirondacks, with $H$. Polhemus, of Brooklyn, to see him stake out a sportsmen's hotel for Apollo Smith, who is alive yet and frisky at 80 odd. That time I met Mrs. WV. H. H. Murray, with "Adirondack Murray." They had a camp of their own at Raquette lake. She talked me down for shooting my .22 at her pet duck, which was paddling about the edge of the water in front. I mistook it for a wild widgeon. When I saw her husband in after years it was at Boston, Montreal and the Guadalupe mountains in Texas, where he was raising horses.

Your venerable correspondent, "Almo," tells in your last number (SPORTSMEN's REviEw) the most wonderful fishing story I ever read of a two and a half hours he and a dog spent in the Scotland highiands in landing a'great salmon when he was a youngster. But I have the photo of a boy of twelve who caught a large Otsego bass by his nose in New York state in the 70 's while looking over the side of the boat into the water. The bass jumped for it and the boy held on until he had him lifted over the gunwale. He was badly lacerated by its jaws. I do not recall the names of the fishing party.

In 1879 the English cricketers had great contests at Staten Island, N. Y., and when their secretary. Edwin Brown, was about to return to England with Richard Daft and his party he wrote a compliment to my assistant, Frank Satterthwaite, for cultivating the trans-Atlantic game in this country. He expressed an intense wish for the success of "Forest and Stream."

Right here may be a good piace to correct another prevalent error regarding the fireproof quality of the salamander, which both ancient and modern literature have represented as being able to withstand a degree of heat which would quickly prove fatal to any other form of life. Yet there is something in the fire tradition. I have had myself the most positive ocular evidence that this interesting species of lizard could walk right into fire and not be burned. But my eyes deceived me. This tiny creature, we know, like all of its kind, is able to adapt its color to its environment; and when in the precincts of a charcoal burner in the Tennessee mountains, I saw one of them assume a scarlet hue and waik right into the cincture of white ashes which bordered the red-hot coals of the woodkiln, I felt convinced that truth had come to the support of allegory and tradition. (Mind, I have not said that I saw him walk into the flame.) However, to be positive, where such momentous issues were at stake, I poked the place where the lizard went in, and almost instantly ousted him out, alive and active. Like the three Israelites in Nebuchadnezzar's fiery furnace, there was no smell of fire on its cuticle. It then occurred to me to test the temperature of its ash-bed with my bare finger, and I found it quite tolerable, and not at all disagreeabie on a frosty morning up in the mountains. It was certainly a secure hiding-place from almost any other creature than an inquisitive naturalist. It was the last place where one would think of looking for anything but a roast.

Half a century ago I was a guest of the Messrs. Russell at the Russell House on Palace street. Both were great salmon fishermen. One had a spliced ash rod 18 feet long, in two parts, which became mine by gift. Not very many of my friends of those days are now to be found in Quebec. Sir James LeMoine, however, is one and Mr. John S. Budden was another. Both are still alive in the agc of 86 , and they write their names to amanuensis letters. Mr. Buden became very intimate with Messrs J. U. Gregory, Geo. M. Fairchild, Jr., E. T. D. Chambers, W. C. Hall, Walter Moodie and Col. Rhodes, and with them he fished most of the accessible waters of the district of Quebec. 
Dr. Elliott Caues, assistant surgeon general U. S. A., secretary of the Hayden survey, and naturalist to the United States government, is well known in libraries. Coues and I were co-workers in the Labrador expedition in 1861, when his labors were first begun, and helped him jerk his Puffins out of their holes and reach with my rifle some specimens beyond the reach of his shotgun. I have always felt cause for gratitude that we were not all poisoned by the arsenic he used in making skins. For the skins went to his collection and the carcasses into the galley pot invariably.

Did I ever see a bear? Oh, yes! Many scores, of size and color. Ever kill one? Not exactly; but Jack Stewart killed one for me among the huckleberry bushes on Grand Lake Island, in Maine, in 1859. We traced his tracks on the sand bottom across from the main land to the island, and stalked him in parallei lines up the island, keeping each other within sight of the water space. Jack jumped him at his noon siesta after his feast, and shot him with his .38 revolver. Then he took off his hide and gave me a two-ounce vial of his oil with my .22 as a voucher of my prestige. But I have seen many others in my backwoods rambles in Alaska, Arkansas, Pennsylvania, Montana, Minnesota, New York and the Maritime Provinces, and I have owned and raised quite a few cubs, black and cinnamon. Some seventeen years ago, when I was in the Catskills, I domiciled with John W. Rusk, hunter and' photographer, at Haines Falls, and we stalked the North mountain quite considerable for grouse and bob-cats. We saw their tracks by the springs, and occasionaily a black bear showed himself to us when we were wading a trout stream, fishing. John used to set a fourteen-pound trap at the garbage pile, half a mile back of the Kaaterskill Hotel, and got one almost every time. He would make a contract with the young sportsmen at Sunset Park and neighboring resorts to get them a bear for fifteen dollars; they to have the hide and carcass. It was a good snap for the fellows, and the three of us would start off for the North mountain. where there are bob-cats and other varmints, and after a search through the woods, swing around to the garbage pile, and at the right moment John would point out the bear and let the man shoot. Of course the trick transpired at once, but the victim never let on; and so the game was repeated, ad captandum, and every young hunter vaunted his prowess and exhibited bear oil, hide and claws as trophies.

The most sanguinary story to my recoliection was the tearing to pieces of the hunter whose cabin was near Fort McGuiniss, Wyoming. Briefly, he had shot a buffalo from his doorway, but before he could get off the hide a she grizzly with two half-grown cubs almost killed him while he was skinning. He fought them all to their death with his sheath, knife, because he had left his rifle in his cabin. 


\section{CHAPTER IX.}

PARK REGION OF MINNESOTA.

On the line of the Northern-Pacific Railway, away up on the western edge of the inimitable Park region of Minnesota, in Becker county, lies Detroit Lake, a delectable body of water, with thirty-seven miles of irregular short line, filled with game fish. It is the central gem of 237 associated lakes, all lying in the same county; a galaxy of pure and limpid reservoirs, only made possible by the impetuous spasms of the glacial period.

* Thirty-seven years ago, when this magnificent transcontinental railway was pushing its toilsome and uncertain course toward the Pacific Ocean, wholly unconscious of the natural wonders before it which the coming years were to unfold, an eastern gentleman of sagacious forecast, who had looked the country over, named Detroit Lake as the future lacustrine resort of the Northwest, predicting the day to be not distant when those who loved nature better than the behests of fashion would flock to this region as their predecessors had thronged the Adironcacks when all its attractions were primitive. He located a home for himself on the chosen spot, and the lapse of time has brought his prediction to the front. Comfortable hostelries, with every modern appointment and every luxury of the table, receive hundreds of summer guests. The bounty of the forests and the lakes is poured into their steward's laps with ever changing profusion, and all those accessories of boats, pavilions, music, livery, lawn and indoor games, which make a watering place continually enjoyable, are provided with the same openhanded beneficence which characterizes their domestic economy. Guests who sojourn here find the comforts of home without its cares; a reprieve from toil, and an indulgence whose exercise is grateful and compensating. Appreciating the advantages of a juxtaposition of town and county-for Detroit City is a county seat with a population of fifteen hundred-visitors have built cottages and villas along the lake shore; clubs with memberships culled from various distant cities have cosy sites on bluffs along the shores. Fleets of row boats, sail boats and naphtha launches enliven the broad expanse of water, and daily picnics make its confines merry.

There is a delightful carriage drive around the entire lake, which is for the most part shaded, and lateral roads ramify at intervals to adjacent lakes and wind through alternate groves and prairie, and undulating farm lands, neatly fenced and radiant with the promise of the harvest. The whole landscape is aglow with verdure and vocal with notes of birds and parti-colored insects. It is odorous with summer perfume. The sunlit ripples sparkle between the flecking silhouette of leaves and fill the view with constant surprises, such as metropolitan treasurers have appropriated millions of money to imitate or reproduce in urban parks. Surely it is difficult to express or enumerate the charms of this rare Minnesota Interlaken! I have looked the entire continent almost over, and am free to say that, for a country devoid of mountain features, and partaking purely of the pastoral, I have found none to equal this in beauty and ever-changing variety. The very contour of the land makes this possible.

Consider! This is the center of the great reservoir system which supplies some 
of the North have their common sources. So close together, and so near akin by Huvial births, that the deities of the woods have always marveled why they turned their backs to each other and took opposite directions, one to the freezing Arctic, and the other to the tepid, sun-kissed waters of the South Atlantic. In the very cradle of these variant temperaments and erratic moods, in this sylvan nursery of flippant streams, we find a congregation of lakes and feeders so numerous that they are hardly named or numbered. The state geologist enumerates ten thousand. In aggregation and arrangement they seem the very counterpart of the galaxy across the sky. There are lakes of every conceivable conformation and outline: round lakes with pebbly sliores; oblong lakes margined with wild rice and reeds; lakes spangled with pand lily pods in June; lakes with deeply indented bays and projecting points half submerged and bristling with rushes; lakes with shores wooded to the brink and filled with wooded islands; lakes with flat shores, bold shores, sloping shores, lakes with confronting bluffs and promontories. There are lakes detached and isolated; lonesnme lakes; lakes in clusters and in pairs; spectacle lakes and lakes in connecting chains, stretching far across the country, and forming uninterrupted thoroughfares for boats and canoes for a hundrcd miles or more.

These chains of lakes constitute the chief charm of the Park Region. The same feature makes the Adirondacks fascinating. I should say, it made them fascinating years ago, when the whole tract was free to random footsteps set thitherward, but measurably restricted now.

An active temperament tires of the monotony of a fixed cottage by the side of an individual lake, with the diurnal row, the bath, and the still fishing, the liammock and the book, and the protracted lullaby of idleness and loafing. It joves to spread its wings and launch out into the unseen and unknown, expectant at every sharp curve of the sinuous river, emerging from the umbrageous covert of the forest into the broad expanse of a far-reaching lake, swinging the oars with a long stoke across its bosom; seeking an outlet where the rushes conceal it, and camping, perchance, where night overtakes, with the veil drawn tightly over the uncertainties of tomorrow. It is only the agnostic who is truly happy, that is, if he appreciates the good gifts of the Great Giver through whom alone he is manifested, or ever can be. What would it satisfy or profit to be omniscient? Dare any one declare that the lapse from time into eternity will vouchsafe a perfect and comprehensive revelation? or that the pursuit of knowledge will ever reach an ultimate fullness of that which is knowable? And if it were attainable, who can say that lethargy would not follow repetition, as surfeit overcomes the anaconda?

Now the wilderness attracts most when it is presented in new and constantly varying aspects; and it was because the Rev. Adirondack Murray was able to so present it that he drew after him a large and enthused following. He did not daze the novice by turning all at once upon his unaccustomed eyes the full effulgence of the sportsman's paradise, but he opened momentary vistas towards the light of truth and read aloud the simple narrative of personal experience and impressions which touched a sympathetic chord in the hearts of his listeners, and it aroused a latent impulse, and provided a new sensation for those who had become surfeited with the perfunctory sound of watering-place festivities.

Already the itineraries of the Park Region of Minnesota are as well defined and substantially fixed as are those of the Adirondacks. Tourists encounter tourists in their incoming and outgoing by lake and river; the whole territory is alive with boats and guides, and the welkin rings with the clarion laughter of 
liealthy women and hearty children, who, thank goodness, live to leaven the soggy, half-baked scdality of jeunesse doree who would incontinently frown them out. Therefore let the true disciples of the rod and gun, and the women with the sun hats and bloomers go up and possess the land forthwith. All the lakes are filied with fish in variety astonishing. There are pike, pickerel, pike-perch muscallonge, black bass, silver bass, rock bass, calico bass, striped bass, white and yellow perch, croppies, sheeps heads, suckers, red horse, sunfish, stem-winders, bullheads, whitefish. sturgeon, and that rare variety of coregonus termed tullibee. And, blessed be the fact! the domain is free, not hedged in like most of the rugged wilderness regions of the west and east. Ah, my comrades with the blanching hair! where are the haunts of our youth? What pleasures of angling we have had in the preterit! and whither shall we look in the future unless it be to the Land o' Lakes! An echo comes out from the glens of the Adirondacks: "Are they not all preserved?" and iteration booms forth from the Laurentian watershed: "Are we not preserved?" Well, yes; quite so. So are finnan haddies and salt mackerel. Along the high crags and in the deep glens I read everywhere the posted notices: "No trespassing," "No fishing here," and I find that vast areas have been made exclusive by law; and that the rich have forged the flat. All along the pathless woods where moccasin tread scarce disturbs the deer, I see the placards as flamboyant as the signs of Mandrake Pills and Schenck's Bitters in New Jersey, proclaiming that only the lord of the manor is entitled to fish or hunt on the forty-mile tract which he has sequestrated, and that this gilt-edged club of ten has vast territorial rights which are beyond encroachment; and I see no open vista through which a hopeful ray of iight protrudes for impecunious toilers, who anticipate for eleven weary months the fruitless outing assigned to the twelfth. And all the Populist legislatures, which form like fungi on the body politic, can bring no remedy, or do more than voice the popular discontent. So I reflect and ask: "What is the perhaps vulgar but very numerous public eventually to do for its fishing?" Must it forego its inherent birthright as a community and crush out its instinct? Where are the ninety and nine to go when every known place is pre-empted by the rich?

* Last fall I was up on the White Earth Indian Reservation, twenty-five miles north of Detroit. Twenty-five hundred red men domiciliate there, where they cultivate small farms and the rudimental amenities of civilization. It is a regal domain, heavily timbered, with much morass and tangle interspersed. Like the "Black Forest" of Germany, it is sequestrated to the lords regnant and harbors many deer and bear, with millions of wild fowl and small game. Mallards, wood ducks, and some other varieties breed abundantly. Otters, minks, muskrats, cranes, herons, buzzards, hawks, ospreys, squirrels, timber-grouse, hedgehogs and gray rabbits are there and propagate. By invitation of a resident, the visitor may hunt, but not otherwise, unless he marries into the tribe and becomes a squaw man; so that the game is hardly worth the candle. Taking a redskin from this section, who had wardered down to Detroit with some roots, skins and small wares to sell, we paddled down the chain of lakes to Fergus Falls, fishing the outlets for black bass, and took the Great Northern Railroad at that point for return. One day the scamp served a bold osprey a shabby trick by transfixing a fish with a spike to a square board and setting it adrift. Then the osprey dropped down on the bait with a whack, and immolated himself on the point of the spike. Injun big medicine-wagh!

* The foregoing chapter was written sixteen years ago, by Mr. Charles Hallock, and is as interesting now as then.-EDITOR. 


\section{CHAPTER $\mathbf{X}$.}

\section{THE UNDINE FISHIXG PARTY UNDER FIRE.}

When the Undine fishing party started up the Chicago \& Northwestern Railroad from the Twin Cities, the day was not more ominous of direful conflagration than any previous day had been for months. During all that fervid summer of 1894, from May until September, the atmosphere had been murky with smoke so that it was difficult to see or breathe, and the constant solar heat made it still more oppressive. All day long, from week to week, the lurid sun glared down through the smudgy vapor like a redhot bull's eye upon the parched and gasping earth. No rain fell, leaves and grass curled up with drouth, springs failed, rivers ran dry, and farmers said such a long dry spell had never been known before in Wisconsin. Occasionally a grateful zephyr would mitigate the fervent heat and clear the air a little, but in general an urremitting calm prevailed from day to day, dead and stifling as the interior of a bake-oren. Persons who had been up the road asserted that the smoke came from forest fires two hundred miles away, which had got into the muskegs or peat bogs, and were bound to burn; that large areas were burning, and unless rain came speedily the whole forest would be consumed. Already large gangs of 'nill men and farm hands were out fighting fire, and some houses and live stock had been destroyed. But the half-baked denizens of the towns who were gasping for relief remembered only the refreshing coolness of the sequestered lakes in that far-off wilderness where they had æstivated the year before, and chafed for its delights. They could not realize that their anticipated refuge was the very seat and source of present misery, and so those who were able to flee the town hastend northward like joyous moths toward the candle fiame; and the fast train bore them on, while the anglers aboard selected flies for seductive casts and counted in their minds the scores of gamey bass, trout and muskalonge which should come to their hands after they reached the delectable land of lakes.

Just here it is necessary to interpolate, for intelligent comprehension of the situation, that the ramifications of the Chicago \& Northwestern system spread over one-third of the great pine region of North Wisconsin, giving easy access to at least thirty trout streams and innumerable lakes with comfortable lostelries at easy intervals, which one can patronize when he does not wish to camp. Some of the lakes are broad and sparkling like inland seas, lying close to the railroad track. Upon others, hidden in the depths of the forest, sunlight never falls except at summer noon. With a portable canvas boat and a guide one can reach most all of them by logging roads, and with a little effort and some endurance of black fies, mosquitoes, deer flies, wood ticks and flies, gnats and midgets, fish in waters which even now are virgin; for the physical character of Northern Wisconsin is such that a moiety of it will remain for half a century at least as much of a jungle as the Florida everglades, to which the country bears some small resemblance in respect to alternate hummocks and swamps, grass meadows and high pinc ridges.

I renember well, a dozen years ago, how the lumbermen and sportsmen rejoiced when this same railroad made its bold push northward to Lake Superior 
and let in the light of the western sun upon the gloomy tamarack swamps and the thickets of balsam, which had grown up in the imperetrable shade; and how, through the open vistas, the sheen of nameless lakes, whose existence had not even been suspected, burst forth unexpectedly, here and there, like the glory of new constellations. Innumerable streams leaped out of the secluded recesses with joyous bounds, and crossed the surveyor's lines, sparkling in the sun. All the waters seemed alive with fish anxious to be hooked, and even the timorous deer waltzed forth into the unwonted sunshine and threw up their heels in the enjoyment of a new sensation. Such an abundantly stocked preserve was never found before. Such multitudes of deer roamed in the forests! Such countless myriads of trout filled the ice-cold streams! Such monster muskalonge ploughed the iacustrine depths like submarine torpedoes. Multitudes of moose paths were disclosed, and elaborate dams built by beavers, old Indian trails in use for centuries, clandestine war paths long hidden by the bush, windfalls marking the tracks of unrecorded cyclones, frames of abandoned tepces with the litter of former occupation strewn about.

Since then gun and axe have made mucl havoc. But enough game yet remains for reasonable sport, and as many giant muskalonge are annually towed out of the inky depths as there ever were. The black bass are just as sportive and quite as numerous, and anglers who make this their favorite resort are seldom persuaded to try elsewhere. As for bears and deer the fires I am to write about routed out far more than were supposed to be in the covers. They appeared by hundreds.

August and September are the months preferred by anglers for lake fishing. The bloom has then passed off, flies have gone and the fish bite better altogether. Probably five hundred anglers were on the Wisconsin lakes when the memorable conflagration culminated on September 1, wiping out expansive areas of forest and licking up towns and villages like straw. In Minnesota the destruction was fourfold greater thain in Wisconsin, especially in respect to loss of life; nevertheless, fifty-four houses were burned at Shell Lake, the immense lumber plant at Barorette Lake was entirely wiped out, and scores of mills and dwellings which were scattered over the country were consumed. The beleaguered inhabitants fought fire for a fortnight before the dread climax came, and when they could hold out no longer relief trains came to their rescue, running the gauntlet of the flames, and carried them to places of safety. Train No. 91 took 400 refugees from Shell Lake to Spooner, and No. 61 made two trips through the fire to Rice Lake, saving many. It was an awful experience.

When the Undine five were put down at Bashaw Lake in the afternoon it was not without misgivings that they saw the train depart. A vague foreboding of evil oppressed them, and the tent poles were not set up with the hilarity which usually atterds the first steps of an outing. From above the dense umbrage ot pine forest lying toward the west a volume of blue and white smoke rose upright into the air like a pillar of cloud, apparently not half a dozen miles away. Here and there on the visible horizon other masses of rising smoke indicated where smouldering or quiescent fires were insidiously eating their way into the precious timber. The atmosphere was stifling and intensely hot; pungent with resinous fumes. Numerous birds were flitting over the waters on uneasy wings, and such small creatures as were moving acted in an uncanny way. The meteorological condition was little changed from the summer normal-namely, a fixed calm, with a leaden sky mottled with fleecy exhalations from the burning forests, through 
which the sun gleamed just now with a pallid, ominous light, as if eclipsed. The presages, presunably, were akin to those which hung over Pompeii before the ashes fell. Suddenly, without other premonition, the wind rose perceptibly, and the tops of the pine forest abreast of the track began to sway with a whirr which whispered of evil. It was the first stiff breeze that had blown for weeks, and it came with a puff, hot as a simoon. Almost instantly the volume of smoke which had so long hung like a pall in the west disappeared, and an intense crimson flush suffused the whole quarter, visible high above the tallest trees; and then in a jiffy the breeze freshened to a gale, and the gale developed into a hurricane, and the whole air at once seemed serried with darts and arrows of flame. Trees bowed and bent half double, and balls of fire rolled off their fronds and dropped hissing hot into the lake. The whole firmament was ablaze and resonant with uproar.

Such an instantaneous change from quiescent mood to wild resorts and devastation was never experienced since the fateful days of Sodom. Every cheek blanched, and a wail arose from a quintette of white lips:

"Great heavens! we are lost!"

The anglers did not then know it, but the terrible blast which they were experiencing was but the outer verge of the great cyclone which was at that moment wiping out the town of Hinckley, in Minnesota, seventy miles due west. Fortunately it continued but a few minutes and then lulled. The respite was grateful, for the heat was insupportable, even under the blessed wind-break which sheltered them. In the brief interval, however, a startling transformation was wrought in the landscape, and singular results followed. It was discovered that the forest was by this time ablaze on both sides of the lake, leaving the devoted party literally hemmed in between the two fires. At first thought, the situation seemed to augur sure death by cremation, but oid Bert, the guide, who was with ihem, demonstrated quite to their comfort of mind that the main fire which had been burning for weeks past just west of the lake had divided, as it is often known to do in prairie and woodland conflagrations, and left a wedge-like area of tinburned forest, which, though not exempt from ultimate destruction, would for the present burn but slowly on the lateral edges; so that the party might eventually find safety by crossing the lake after the fire had swept past, provided they could only keep from being baked or roasted in the interim. Their situation was very much like that of a Thanksgiving turkey in an old-fashioned tin oven.

After a brief lull the tempest rose again as violently as before, and thereafter, for two agonizing hours, there followed intermittent gusts and lulls. Great surges of flame would fill the air for a time, swooping down on the lake with the rush of demons, while pennants of fire streamed out from the tops of the pines and masses of blazing matter hurtled like missiles over a battle field. Then all would be still again, involving awful suspense, with direful explosions in the air, pyrotechnics and rings of fire. Meanwhile large numbers of deer were seen to emerge from the forest and plunge into the lake, single and two or three together, swallowing the water in great gulps. Some bears, too, came in. Multitudes of birds fluttered over its surface, and collections of small animals and myriads of insects gathered on the cleared space between the forest and the shore. Occasionally an eagle, with languid beat of wings, would come soaring before the advancing flames, and once a poor, unfortunate which was just able to reach the top of a tall, unscathed rampike was seen to cling to it for an instant and then topple over, exhausted, into the abyss below. Least expected of all was the egress 
of two Ojibway Indians from the fringe of forest who shuffled down to the margin of the lake, where they drank inordinately. Then, soaking their blankets sn the refreshing fluid, they wrapped them about their heads and shoulders and sat down, with their legs in the lake. Taking the hint, the fishing party were quick to follow suit, and there they sat for the remainder of two mortal hours of dread and suffering, uncertain of the end, when, fortunately, the hurricane spent its force and the fire had accomplished its greatest mischief.

The following morning, as soon as the glowing embers had cooled sufficiently to permit a passage, a train came through and picked the anglers up, blistered and half blind. Their departure was like a release from Hades. Oh! that blessed minister of deliverance! And rain came, too, not long afterward. In the torrid cities the weather bureau had foretold its occurrence and one could almost hear the patter of its advancing mercy as it hastened from the west. Hundreds of stricken and dying creatures were panting for its blessed relief, and finally it came, cool and beneficent, stirring the drooping leaves and filling the distressed fields and homes with refreshment and good cheer. Then followed a copious deluge which drenched the kindling faggots all over the burned district, preventing the spreading of the fire, and when the next rosy dawn flushed the breaking day, lo! the streams were swollen and turbid, and water stood ankle deep in the hollows of the meadows and ploughed fields. 


\section{CHAPTER XI.}

RANDOM CASTS IN THE LAND OF LAKES.

THE state of Minnesota is so emphatically the land of lakes that this designation should become peculiarly its own. No other region of the globe can compare with it in this respect. In its central portion the greater area is water. The known number of lakes is seven thousand, and an estimate of its unnamed and unexplored lakes adds half as many more at least! I remember to have sent you a year ago or more an enumeration of the larger number, given by counties.

As Commissioner of the Department of Lakes and Summer Resorts, represented at the New Orleans exposition last winter, it came within my province to visit no less than fifty-eight of the counties in this state, and this duty has made me familiar with their physical features. In the "Park Region," now easily acsessible by the St. Paul and Manitoba Railroad, where the lakes are most numerous, I have been interested in noting the many pairs of lakes-considerable bodies of water separated by narrow strips of land which are often. a mile or more in length. Some of these are mere causeways, like a railroad embankment, wide enough for two carriages to pass abreast, while others are studded with oak trees of many years' growth, contributing much to the sylvan beauty of the landscape. These causeways invariably unite what were origihally projecting points of land in an individual lake. It is a peculiarity of nearly all the larger lakes that, wherever there is a point, a bar makes out, dropping down at the end into deep water. These bars are sometimes wholly of sand, but the submerged portions are usually made up of round boulders. In the deep water are the best fishing places for black bass in mid-summer. I suppose these bars are formed mainlv in early spring by shoves of ice, assisted at various times by wave action. I notice that the shores of many lakes are encircled by a narrow embankment or ridge some three feet higher than the land behind it, and these are being continually enlarged by storms and movements of ice. I have found many of these ridges bordering meadows and on high ground in the midst of growing timber, indicating shore lines of ancient lakes, which existed at a time when a larger portion of the country was submerged than now. Geological inference easily accounts for such formations, but they are often puzzling to the uninformed.

The distribution of fish throughout these lakes is very interesting. The pickerel everywhere prevail. Bass are found within a large but circumscribed area. of which the greater part lies east of the Mississippi River. In the northeastern lakes, east and north of the St. Louis River, lake trout are found, notably, and I don't know but exclusively, in the three extensive counties which border Lake Superior. The great northern pike and the mascalonge are found in many of the lakes in company with the black bass. Wall-eyed pike are even more widely distributed than the black bass, but far less so than the pickerel. In Cook County Mr. John M. Miller, the county auditor, informs me that there is a variety of white bass speckled blue, but I have not seen it myself. It is caught in a lake in Range 5, west

Referring to the weekly records of big catches which are printed in the American Angler, I confess to a feeling of something like disgust whenever I read 
them. In the name of Izaak, what is the use of catching so many fish as the majority of anglers aspire to do? Does the record of great counts establish one's title to superiority as an angler? Does it prove anything more than a superabundance of fish? I know that these boat-loads are captured by main strength and not by delicate manipulation, because ten minutes is little enough time to land a heavy fish on fine tackle. Six fish an hour for four hours' morning fishing and two hours' evening fishing-thirty-six fish-is a splendid score, and all that ought ever to come to a reasonable man's boat or basket. Just think of the labor and finesse involved in the feat, especially in a tideway at an outlet, where, the current is strong!

Within the past five years the Brule River, near Bayfield, Wisconsin, has come into prominent notice as a trout stream, and since the Northern Pacific and the St. Paul and Omaha Railroads have extended their lines almost to the river's brink, making the journey easy and short, anglers are flocking to it by scores. I think the river is one hundred and fifteen miles long. It is a marvelous river, and I know of no water in the world which is so abundantly stocked with trout. It fairly teems with them. Where it debouches into Lake Superior its mouth is broad, and in June the big four-pound trout come cruising along the rocky shore from far and wide and are caught without stint. Tens of thousands of very large trout are taken from the Brule along the-entire stream every year, and I cannot imagine how it is kept from depletion except by annual accessions from the great lake. It is no uncommon thing for a couple of anglers to report one thousand trout as the result of three or four days' fishing! Now what is the use? Couldn't they be content with enough to eat and a quantum suff to bring away? What becomes of the first day's catch? "Ask of the winds," etc. Only the take of the last day will be fresh enough to fetch home.

But I can tell you of something worse than this-of men who seine the lakes of fish and feed the product to their hogs!. Why cannot men learn to be provident of good gifts and considerate of other people to come after them?

During the month past nearly all the lakes have been "in bloom." When they are in this condition the fishing is slack. The bloom is the suspended seed of aquatic plants, which are disseminated everywhere, and finally become water soaked and sink to take root and reproduce. There are different kinds of seed, and, like the seeds of land plants, they do not all bloom at once, so that some lakes are clear at the time when others are "working." My impression is that the fish eat large quantities of them, and, becoming surfeited thereby, decline to bite the anglers' baits. I doubt if the seed has any deleterious effect upon their gills. It is in a sense a protection to them at a period when many kinds of fish are recuperating after spawning. It is a protection also to the young fry. The water is thick and partially hides them from their predatory enemies. There is nothing noxious about the water when it is in bloom, though it has been stated that cattle have been made ill by drinking it. A strong microscope will assist the student in his investigation of this phenomenon.

There is a fish quite common in the lakes of Minnesota and Wisconsin, called the sheepshead (Haploidonotus grunniens), which is not generally recognized and not often caught. In some waters I have found it quite palatable, and in others it is quite the reverse. They are not usually esteemed for food in waters east of the Mississippi, but I find the Minnesota article make an excellent boiled dish or chowder. The sheepshead are the only submarine musicians we have in the West, 
and in some localities are vulgarly yclept "grunts" by those who call themselves good judges of music.

I notice by the Bismarck Journal that a man named Harmonie has started out alone from Livingston, on the Yellowstone, to make a canoe voyage to New Orleans. It is easy enough to start, but not so easy to get through. The Yellowstone above Glendive is filled with wicked rapids and is the most dangerous part of the cruise. Men often run the Yellowstone in suitable boats, and many are drowned every year, notwithstanding. There is a gentleman here at Lake Minnetonka, a professional oarsman and boat-builder, named Capt. John B. Brooks, formerly of New Haven, Conn., who ran from Livingston to a point in Iowa, but his name would carry him through where others would fail. He came down in a fifteen-foot boat, the latter part of the way through running ice in November, and suffered a great deal of hardship. He passed the worst rapids by keeping the head of the boat up stream and plying the oars to guide and steady her, dropping astern as rapidly as good judgment and circumstances permitted.

$\mathrm{By}$ and by you will hear from me in Alaska, and I hope to add something novel to the contributed matter of the Angler.

* Written in 1885 .

REMINISCENCES OF BIG LAKE.

TwentY-FIVE years ago this month of *June I started from St. Paul with a prospecting party for the Red River Valley, from whose distant but now easily accessible precincts $I$ am at present writing. In those days there were no stage coaches. There were very few houses a hundred miles north or west of the embryo capital of Minnesota. The Red River Trail drew out its sinuous length over an unexplored prairie to Pembina on the Canadian boundary, 400 miles away, and over this route we made our tedious and lonely journey, not without danger of molestation from narauding bands of Indians. Camping the first night at Big Lake, some twenty miles from St. Anthony Falls, we found a single settler located near the shore. He was sole monarch of the solitude. The lake was nearly circular-one of those beautiful gems for which Minnesota is so famous-and its pebbly shores were encircled with a belt of lily pads, whose pure white blossoms breathed fragrance into the atmosphere like the foral wreath of a rural bride. While hunting for agates among the rounded stones on the margin a crank and dilapidated dugout was discovered among the alders, and simultaneously the plash of some sort of large fish on the outer rim of the pads suggested sport and its most favorable opportunity.

If a person could have walked with an elfin tread over the green enamelled platform of those broad floating pads, he would have speedily discovered their glossy surfaces to be populous with the lower orders of animal creation; slippery green batrachians, filmy spiders, wrigglers, caddis flies, beetles, ephenteræ, and a whole menagerie of creeping and winged insects. He would have soon learned why the big fish were thus patroling the outer rim of the circle and foraging along the border. A little scrutiny would have shown him that the lesser world of inferior things is like the higher realm of human existence; that there are reckless, careless and self-opinionated among all classes; that many are self-willed and venturesome; that often, when we are in the midst of fullest enjoyment and the confidence of apparent security, danger lurks; that death is hidden among the flowers and beneath the cloth of gold. Unwary frogs would leap from the pads into the pellucid depths, and awkward bugs tumble over the edges into the brink, hardly touching the surface of the water ere they were swallowed into the capacious maw of a gigantic 
bass. Meanwhile their unsuspecting comrades foraged for sweets among the coronals and petals of the delicious lilies, and sauntered under the umbrages of the wax-like calices and waltzed about the shiny floors of the broadening leaves, destined, possibly; to pass off next into the abyss of fate.

It was at the first flush of the long summer twilight which lingers far into the night of the northern sky, and all of our prospecting party were tired with an unwonted tramp, for they had not yet become hardened to the average of thirty miles per diem (which afterward became their regulation march). An early bed offered greater attractions than angling. No one had contemplated trying his luck until the next morning, and quite likely the most interested of the party would have continued to loll on the grass in camp and listlessly watch the intermittent plashes of the fish around the lake, had not the already heightened interest been enhanced and intensified by the shadowy apparition of the pioneer settler creeping through the brush toward the water.

He held in his hard-fisted grip a ponderous wattle, with the tip projecting forward as he strode, and when he reached the margin of the water he waded boldly in among the pads up to his middle and lifting the pole with both hands slung it first backward over his shoulder and then forward toward the water with a mighty "swish!" Some large object gleamed momentarily from the end of the transitory radius which his heavy line described, and cutting an impalpable perimeter in the air, came down upon the bosom of the lake kerswash just outside the pads! It was a whole frog which he had on for bait, and its dangling legs were tremendous to behold The astonished spray which the blow threw up had barely time to reflect the crimson of the glowing west ere there was a great commotion in the water and a struggle for the pole; but presently, with one mighty heave, the doughty fisherman bent his inborn force and high in air another object sped brushward, and like a collapsed meteor fell with a sickening thud into the woods behind, far out of sight. A protracted investigation discovered a three-pound bass, "big-mouth" variety, and no mistake, for the whole frog was in it! This same unmutilated frog answered for a second fish, and as promptly a second fish answered to the bait.

A repetition of this extraordinary achievement stirred the latent enthusiasm within my own breast and kindled the fire of the ardent angler. My tired limbs forgot their fatigue, but my hands and genius had not forgotten their cunning. Hastily rumaging through my camp kit I found a trolling spoon and line, and rushing down to the canoe I jumped into it and shoved out into the lake. The wind was. blowing briskly off shore, so laying aside the paddle I let her drift across and paid out line as she went. The dugout was so narrow that I could not sit in it squarely; but lying sideways on my hip I did the best I could, and presently got a thumping strike. My position was so awkward that I couldn't half see behind. I couldn't see my fish unless the boat was moving sideways, but I managed to haul in by a sort of hand-over-shoulder maneuver, and finally got him into the boat. I managed to get three fish in going once across the lake, and as the supply was ample for our breakfast I left the canoe on the lee shore and walked back to camp.

Those were the first bass I ever caught in my life, and the sensation was overpowering. I don't know if Big Lake still keeps up its reputation as a fishing resort, but it fairly swarmed with black bass in those days, and I envy the old pioneer the sport which he might have had if he had only known how to make the most of it.

* June, 1882. 


\title{
CHAPTER XII.
}

\author{
A PERILOUS ADIENTURE AT KAX.IIVIIA F.ALLS.
}

I AM moved to indite a reminiscence of Kanawha Falls, covering a moment of fearful peril, out of which a kind and overruling providence for some wise purpose doubtless provided a way of escape. Even now, thirty-five years afterward, I never hear the roar of a cataract without associating it with the rumble of an express train dashing through a rock cut, and a vision of two helpless human creatures clinging with lacerated fingers to the excoriating side walls from which the suction almost tore them.

You know there is a curvilinear cut through the marginal ledge which abuts the river quite within gunshot of the Falls. Well, at times, when meteriological conditions favor, the undertone of revolving car wheels blends so intimately with the resonance of the tumbling waters that the keenest sense can hardly distinguish them apart. You are aware of this fact also? It was like this, then (ora pro nobis!), on that beautiful July morning in 1876 , when wife and I went fishing high up in the life-giving mountain atmosphere of the Gawley canyon, 2,000 feet above the level of the deep, deep sea. S'death! we didn't know it at the time, but we were even then "betwixt the devil and the deep sea," but of this later on.

The inimitable guide books of the Chesapeake \& Ohio Railroad Company, on whose picturesque trans-mountain line this wild bit of scenery is located, says in its mild, liquescent way: "Kanawha Falls is a pleasant and picturesque scene of watery waywardness. A ledge of rock thirty feet high extends the width of the river, and the waters tumble over it in tumultuous fury. The clear mirror-like basin below the falls stands in strong contrast with the foaming cataract." "Vatery waywardness" is musical alliteration, but it is not sufficiently intensive. "Tumultuous" is correct enough, though I observed no "fury." Much depends, I ween, upon the situation of the beholder, whether his canoe be careering wildly over the crest of the cataract, after the fashion of the love-lorn maiden in Indian legend, about to make the fatal plunge, or whether it be boating quietly on' the "minror-like basin," aforesaid, with bending rod and taut line fast to a five-pound bass hung in the swirl of the midway rock. Moreover, there is an expression of expansiveness in the half-tone illustration which is not true to nature; for one might imagine an illimitable horizon with ultima thule lying indefinitely beyond, whereas, really, the inclosing hills of the Blue Ridge drop abruptly almost to either margin, and the rapt beholder, sitting in his boat, looks upward to the deep blue zenith against which their rugged summits are ambitiously outlined, instead of far away into Utopian space-envying, forsooth, the flight of the water ousel, which permits the enjoyment of both elements alike.

Mr. Editor, I am not apt to deal in rhapsody, or go into ecstacies over transcendent landscapes. Your stated summer correspondent, turned loose, with only a day off, is always enthusiastac. His descriptions of sylvan or bucolic haunts are therefore subject to modification. Like good beer, they are heartiest when they cffervesce. But I am no adolescent out for a holiday. I have looked a large part of this broad continent over, and am free to say that for natural features or changeful aspect, none can hardly be more beautiful and more striking than those 
about Kanawha Falls. I passed a pleasant week there with Mr. Beckley, landlord, I think the name was, and every morning during my stay my young wife and I would pull our skiff from the boat-house landing up river into the spray of the cataract, and letting it drift into the eddies, cast deft lines at the edge of the swirl where the still water meets the rough; and oh! brethren of the angle, as sure as I live, the black bass which sport in the Kanawha are full of game and pride of life, and the water has that odorous woodsy smell which savors of the lotion which naiads use in their baths. The sumbeams flashing on the wavelets are the reflection of their bright glances, I ween, and the soft summer zephyrs seem to waft to our mortal ears the whispers of their amours. Oh, my heart! What a blessed lot it is to be a naiad! Sometimes I would look into my wife's bright eyes, as she sat in the stern sheets, and almost wish that we two were both naiads together, at home with the brook trout and shiners, and newts, and batrachians: and gossamerflies, and all the other quaint creatures which populate the falls and the pools in the glens. Then, in a happy-go-lucky sort of way, with nothing to think of or fear, we might toss up the spray with our hands, and join in the roundelay of the opalled denizen when he exclaims:

\footnotetext{
"I am Salmon Fontinalis,

To the sparkling fountain born,

And my home is where oxalis,

Heather bell and rose adorn

The crystal basin in the dell;

Undine, the wood nymph, knows it well,

That is where I love to dwell."
}

Yet. after all, the pleasure of a summer vacation depend more upon one's own moods than upon environment. Nature is a potential accessory, but if we are gross-grained or morose, all the naiads in Undine's realm could not make us happy. Toads, tarantulas and blue devils would appear under every turned-up stone, nez parc?

As I was saying of the Kanawha bass: They are large and comely, and heavy of weight, and they pull on the line like the stroke oar of a Harvard crew. They leap, dive, plunge, sulk, sprint, gyrate and perpetrate all those perfunctory gymnastics which are set down in the fish books, not only bass, but wall-eyed pike, yclept jack salmon on the Allegheny slope, running sometimes to twenty pounds in weight, which are caught best in deep water when the wind is blowing briskly, with cut fish-bait or minnow, but sometimes with gaudy fly or spoon, for they are capricious, both as to food and feeding grounds, seldom being found in the same location or depth of water. There is no better table fish when dressed off with a hatchet, sccundem artem, a chop at the head and a clip at the tail, two slits along the length of the backbone with the keen edge to take out the dorsal, a flip of the skin from the body like drawing off a glove, and lo! the thing is done! The entrails follow the gills and a clean chunk of boneless meat results. A Minnesota half-breed taught me that little trick at Detroit Lake, but I wonder how long it will take me to learn to do it half as well?

The whole mountain region in this section is full of game fish. There are speckled trout in Cherry Creek, which flows into the Little Kanawha not far from Ronceverte; in Falling Springs, Anthony's Creek, near Quinnamont, in Rawey County; in Lost Creek, Glade Creek and several other clear-water streams quite accessible from points on the railroad. Jackson's River, New River, the Greenbriar and the Gawley harbor black bass, pickerel, perch and suckers, with Covington, Clifton Forge, Talcott and Lowell as eligible starting points. Get off at Alderson, IVest Virginia, and fish east to Fort Springs and west to the Greenbrier stock 
yards and you catch trout and bass. Indeed, the entire Allegheny range from Ronceverte to Dunlap is one continuous game preserve, abounding in deer, bears, turkeys, partridges, rabbits, squirrels, possums, coons and the rest, where I would sooner take my chances for a bag full or a back load than in Dr. Weble's or Austin Corbin's expensire preserves. The heart of the Alleghenies and Blue Kidge, with their stupendous subdivision, is almost a duplicate of the Catskills, but with more cultivation in parts and a greater diversity of products. Its canyons are deeper and wilder than the Cloves, and at Covington, for instance, the landscape is more extended than at Haines' Falls or Hunter, with inclosing mountains even higher. Corn fields and log cabins alternate with princely villas and up-to-date hotels. Wild mountaineers with guns and pocket pistols board the trains at the way stations much after the fashion of cowboys in Texas, but with much better behavior, and the experiences of a tenderfoot are likely to be quite as racy and stimulating as in Wyoming if he will only drive away a few miles from the railroad. All winter long, until March, there is sport for the gunner and bear hunter. Deer are as plenty as wolves in Montana. One party started sixteen in three days and got four of them, lately. Turkeys can be had for the baiting. Quails rise in all the pea patches and green fields. Possums swing from the sweet gums and 'simmon trees at the full of the moon. Coons come down from their perches at command when treed, and sport in the forest runs free all through the winter months, till March. About the middle of May, when the mountain streams clear, trout fishing begins; and from that time on, for nine full months succeeding, there is fulsome enjoyment with rod and reel. Selah.

And now, having delivered up the keys of the fastnesses and keeps of the forest, I come to the pivotal part of my narrative, and relate my experiences in the road-cut at Kanawha Falls:

By some strange and happy chance, we had been reading that very morning of an accident that had happened to an army officer and two ladies who were caught in a similar trap the previous day with fatal results, and our conversation was upon that catastrophe as we wended our perilous way along the railroad track. Our objective point was a jutting ledge which overlooked the falls, where we expected to make some shore casts for bass. The cut was narrow, the track single, and the curve so sharp that we could see but a few rods ahead. I was just saying that it might be well to get out of the cut as expeditiously as possible, when the premonitory rumble of the approaching train caught our ears. At first it was muffled; then rose to intenser sound. I had heard falling water do the same way, alternating in the cadences, and it seemed not unnatural. But I was not satisfied. Had we not been on the alert we would certainly have been run down. As it was, the shave was close.

"Is that the roar of the falls?" I asked apprehensively, with an ear to windward.

"Ye-es? No-by heaven, no! Look!"

The big bullseye of the locomotive shot into view like a torpedo from a Zalinski gun. Quick as thought, by that fortuitous prompting which enables the mind to formulate expedients on the jump, without forecast, I caught my loved wife from the track and almost flung her against the face of the side wall, where I pinioned her with arms extended clutching desperately to such projections as had been left in the blasting. I never hugged her so hard before! Fortunately there was a depression at that point, though it did not form a deep enough niche to accommodate the living statuary with comfort. The train whizzed by like a rocket 
with a clatter and deafening roar such as a man hears when he is drowning. My face was toward its approach, and I saw the engineer looking out of the side of the $c a b$, being as white as a ghost. In a twinkling he was gone, but after that instant the procession of coaches seemed interminable. A string of Dakota "empties" was never so long. Before it had half gone by I declared I could hold on to the rocks 110 longer. The draft of reflux air which the train displaced in its passage pulled at me like seven devils, tearing me away. If I quit my hold I would not simply fall; we would both be hurled like winnowed chaff under the rattling wheels. My fingers bled, and I felt the flesh tearing from my hands.

At last the ordeal was over and I fell like a log. Wife bent over me an'd helped me rise. My palm-leaf hat made a good fan. When I had leaned a while and rested, we dragged ourselves out of the cut, homeward. We forebore to fish that day. As we neared the hotel we met a party hurrying out, and received their greetings. They had apprehended worse results, taking their cue from the trainmen. 'Twas a close call. 


\section{CHAPTER XIII.}

THE PRINCESS AND THE SALMON.

Agarn the Restigouche! Egad! it is becoming a famous river! For what wielder of the two-handed rod, at home or abroad, has not heard its praises sung anon, iif, indeed, he has not himself tasted its delights? What salmon fisher of renown has not whipped some portion of its majestic length-the largest, longest and noblest of all Atlantic salmon rivers on either continent?

And why not the Restigouche? Has its too familiar name become a bore? I grant that there are other rivers wilder and more "wicked," some of them seldom visited, which might inspire a momentary interest by their vagueness or their novelty, but to come down to an authentic, well-tried stream, which is statedly crossed by angler's casts, where can there be found a more captivating stretch of water than the outflow of the Restigouche? Or a wilderness haunt more charming than its source among the alders of the "Waagan?"

For my own part, as soon as ever the season of green peas comes round my thoughts revert instinctively to this New Brunswick stream, and whether I visit it or abstain, or whatever I do, the old familiar name with its many cherished associations will never grow trite or tiresome. Its impetuous flow may chafe and scour the rounded pebbles on its bottom until the end of time, but this abrasion will only make their polished surfaces all the brighter, and I shall never cease to yearn for the music of its rapids and the crooning of its pines.

\section{IT HAS A RECORD.}

The Restigouche has a notable record withal. Governor Boucher expatiated on its charms so far back as 1663, 248 years ago, in his engaging "Histoire Naturelle des Oiseaux et des Poissons de la Nouvelle, France." A century later, in 1761, Mr. Jaffray extolled its attributes as a salmon stream. He was geographer to the Prince of Wales and an accepted authority, having written a large folio on Canadian birds, fishes, woods and rivers, which he entitled "The British Domain." In 1845, after another lapse of nearly one hundred years, Fred Tolfey, a British officer much quoted by Frank Forester, and in fact his chosen guide and mentor, published two illustrated volumes, which were printed in London and received with signal favor.

More recently, in 1863, J. M. Le Moine, the historian of Canada, described the Restigouche in glowing terms in his "Wilderness Journeyings Through New Brunswick." Harper's Monthly took up the favorite refrain in 1868, and Hallock's "Fishing Tourist" continued it in 1873 . Since which date the river has become more and more the Mecca of high-grade anglers, until at present all its lower reaches are occupied with stands and cottages, and a fishing privilege along its exclusive borders is valued more than a college diploma, the mere possession thereof being accepted as a warrant of social standing.

\section{RECOLLECTIONS OF A VETERAN.}

Yet, after all that has been said and printed, how much of its eventful history remains unwritten! For my own part, I could fill a volume with personal reminiscences of hard-fought battles, lost leaders, blank scores, and hung-up casting lines which appear as marginalia in the retrospect; and it is upon my pen's point, right 
now, to recount an incident of ambidextrous prowess wherein no less a personage than an estimable daughter of Queen Victoria of England took a hand, maintaining an obstinate contest for two mortal hours with a 28-pound salmon which had the temerity to enter the lists with her royal highness. This happened years ago, before the era of clubs and cottages, while the wilderness was still a solitude and few champagne bottles glistened on the margin of the stream. Only a few Canadian officials who had learned the superlative quality of the fishing had acquired some privileges on the river, and one of them, Mr. Brydges, of the Grand Trunk Railway, had built himself a house boat christened "Great Cæsar's Ghost," which teams of horses were wont to haul to advantageous stands up the main river or into the Upsalquitch or Patapedia and even to the Quatawatatamkagearick, sixty miles above. On the occasion in mind this novel conveyance was appropriated by the Marquis of Lorne, then governor general of Canada, and the vice-regal party, with the princess Louise pre-eminent. It was fitted up with dining-room, cabin, promenade deck, berths, kitchen, and every domestic convenience, and was regarded as more desirable than a short camp, because it could be shifted, and when in midstream was comparatively exempt from mosquitoes and midgets.

Returning to her royal highness, it comes in my way to mention that I was stopping at that famous old hostelry of line officers and anglers at Quebec, the St. Louis hotel, when I received one morning the following mandatory note:

Monday.-Mr. Hallock: The Marquis of Lorne will be at my office in a few minutes. If you wish to see him, come down at once.

\section{J. U. Gregory.}

Mr. Gregory was naval agent at the port. Obedient to the behest, I mounted a caleche at once and rattled down the hillside through the old Prescott gate to the lower town and along the one thoroughfare under the cliff almost tc the very base of Cape Diamond, where so many people were killed by a landslip not many years ago, though, as luck would have it, the naval office escaped. Fresently I was ushered aboard the government steamer Druid, which lay at the admiralty wharf, and presented without ceremony to Major De Winton, Lorne's aide de camp, who has since received signal promotion in India, and by him to the marquis.

\section{HOW THE PRINCESS APPEARED.}

While we were all engaged in discussing salmon rivers and the most killing flies in an informal sort of way, the princess came forward to the quarter rail where we were standing and was gracious enough to interest herself in the conversation and to inquire about the prospects of the trip to the Restigouche, whither we were all bound. She looked severely plain and respectable in a dusky alpaca dress and seaside hat.

After an uneventful interval she mentioned incidentally that she was covering a lounge in the cabin, and wouldn't I step down the companionway and inspect her handiwork? Without claiming to be a connoisseur in such things, I put on my best possible face and expressed myself pleased with what I saw; and, indeed, everything in the apartment was very charming and domestic, with a quiet half-tone about it which was altogether too soothing and assuring to a republican citizen outside the pale of the court. I afterward begged a piece of the chintz covering as a memento of the interview and contributed a couple of salmon flies to the vice-regal outfit.

Then, the interview being formally concluded, I returned to the deck and backed circumspectly down the gangway to the quay, with pulse in equipoise, and received the congratulations of my official friends. Subsequently, we all duly arrived at the 
Restigouche by our several routes and conveyances. "Great. Cæsar's Ghost" received the royal guests, and being duly manned and victualed was towed up stream to the Indian pool with a lounge aboard.

Ah! what a marvelous series of pools there is from tide-water to the Kedgewick, overshadowed for the most part by the high hills which flank the river on both sides and alternate with long stretches of white water which sparkle in the noontide sun. The upper river runs off the divide through sixty miles of broad, level forest, expressing itself in cadences which vary from a murmur to a roar, according to the pitch of the fall, and receiving a small brook here and a rivulet there until it finally mingles with the lusty Tom Kedgewick, which is the larger of the two.

It is an exhilirating run for a birch canoe, though somewhat gloomy and monotonous in cloudy weather. But as soon as ever the river becomes expansive with greater depth and volume and wider bottom the scenery changes rapidly as one passes along, not only from placid pool to impetuous rapid, and from impinging crag to sloping shore, but each rapid has its peculiar moods and features, and each separate landscape some striking point of view.

It was wild enough, too, in those days, with no trace of human habitation for the entire distance of 120 miles, except old Chane's and Merrill's log shanties, which were a day's journey apart, until we came to John Mowat's, at Dee Side, now in the midst of a fashionable quarter.

Once. I remember, when careering down the crests of a rattling rapid, one canoe came near striking a big bull moose which stood in mid channel to rid itself of flies, the huge animal not seeming to comprehend the situation of the approaching object or to have the slightest conception of the rapidly diminishing distance as the birch swept on. But for an opportune flip of the paddle we should have hit the brute full in the face!

\section{PRINCESS LOUISE AND HER SALMON.}

The sun was off the river when the princess fastened to the big salmon the evening of her arrival, for the hills were so high as to throw their shadows over the surface by four o'clock of the longest day of June. The marquis was occupied upstream and the major below, each with his canoe and Indian guides, and her highness had the fun all to herself and her gaffer for a full hour before her gentlemen friends became aware that anything momentous was afloat. By that time the shadows had deepened and the anglers were prepared to reel up for the night. On arriving at the home pool they found the indomitable heroine standing on the bow of "Great Cæsar's Ghost" with the stock of her salmon rod pointing skyward and the limber part of it bending over the dark and solemn water in a great big curve, from the point of which the line ran down into the depths, taut as a fiddle string. Her canoe was hauled alongside of the scow.

She said the fish had been sulking for fully twenty minutes and seemed determined to make a night of it. The water was so deep that her gillie couldn't start him by throwing in stones or prodding at him with the setting pole, and as for lifting at him with the line one might as well think of trying to raise the dead. Was it a very large "fish? Indian Joe said, "Suppose him big as one canoe!" Had he showed himself at all? Oh, yes; many times. He had given her ladyship the liveliest sort of a turn. Was she not fatigued, and would not the marquis spell her for a while?

But the plucky woman declined to share the honors with her husband and held on persistently to the rod. Meanwhile the attitude of the principals remained in status quo. 
Now, an hour at the butt of a two-handed rod is a pretty severe test of physical endurance, which few considerate salmon ever impose upon the brawny sex, and much less upon feeble womanhood, though exceptional occurrences enable English ladies to "show the mettle of their breeding," and sometimes American ladies, too. I am proud to say.

\section{HOW IT WAS DONE.}

The fact is, the princess had hooked that salmon in a pool a half-mile above the moorage, where Joe had pointed it out to her on a sunken ledge which the canoe passed over. Joe was handling the canoe alone, sitting in the stern, sometimes holding her with the paddle and anon letting her drop down with the current, checking her as occasion required. With another paddler in the bow the fish would have been observed sooner. The favoring chance for the angler was on the forward downstream cast, but the instant the course overran the fish, perceiving that the opportunity had passed she caught on to the only alternative and gave her rod a dextrous backward cast whereupon the fly had no sooner touched the surface of the water than the fish rose. He was evidently hungry for he came up with a bulge and threw his whole weight on the line, fastening the hook firmly in the tough gristle of the jaw, then settled heavily to the bottom, like a log, where he could be plainly seen lying motionless. Like Bad Dickey in the burlesque, it took him some minutes to discover that he had been stabbed, but as soon as he did wake up to a realizing sense of the crisis the circus began. Up and down and across the pool, in the water and out of the water, into the bank and under the boat, he led that indefatigable lady a chase and a race until he finally floundered down the main rapids through a quarter of a mile of rough water into the thirty-acre pool, the canoe following like an arrow. Here he would seem to have finally exhausted himself in a series of runs, whirls, gyrations and splashes, and a truce naturally followed. During the wait the princess was glad to accept a glass of cordial, which she needed much.

Meanwhile the brave lady had been many times out of the canoe and on shore, and sometimes knee deep in the water, according as better advantage of her captive could be obtained, and throughout the long ordeal holding her end up heroically and wielding the supple wand as her august mother wields the scepter, leading her subjects or constraining them by the mild potency of deft handling and gracious finesse. Only when the salmon made his desperate leaps she would drop the tip deferentially, preferring a temporary concession to irretrievable loss.

\section{THE FINALE.}

And so we came eventually to the concluding act of the drama in the thick of the gloaming, with the shadows of eventide settling upon the pool, by which time the great fish was beginning to shake his head omniously and the princess could feel the tremor of the line. Joe noticed the vibration, too.

"Suppose um take canoe now?" he suggested. Then without awaiting formal assent he brought the light craft conveniently to her feet and she slipped down adroitly off the scow, motioning one of the other gillies to follow.

Every one suspected that there would be another tussle after so long a wait, and so the event proved, for the lady had hardly stepped aboard the canoe before the salmon made a big break for up stream and reeled off a hundred yards of line so swiftly that the winch fairly shrieked with the friction. But the mechanical drag and sag of the line soon checked the spurt, and the lost line was gradually retrieved, the fish coming in doggedly and disputing every inch. This brilliant run seemed to be a despairing effort of the captive to get away-a concentrated energy of strength 
and purpose-inasmuch as the devious tactics of the earlier struggle were not renewed. Neither did he essay any new expedients.

For the next half hour it was alternately give and take-a succession of short circuits, an obstinate boring against the current, with occasional spasmodic runs and broad display of tail, until at last it became difficult to see the shore or even the position of the fish. However, there was plenty of elbow room, and the canoe had only to follow its caprices and erratic courses, the two canoemen plying their paddles vigorously whenever he unexpectedly quickened his pace. Thus the struggle was narrowed down to a mere question of the survival of the toughest, subject all the time to mischances and errors of judgment.

At length, it may be stated, the party aboard the scow became anxious as well as hungry, for the royal angler made no sign, and in despair of a finish the marquis and his secretary took skiff for the opposite shorc, where a group of dusky figures could be barely discerned, arriving just in time to see an uplifted rod swing heavily back toward the wooded bank, and to catch a glimpse of a pallid gleam beside the river's bank and the boil of an upward surge. Then almost instantly followed a sharp dip and a splash and a simultancous sigh of relief. There was a flip-fiap on the grass, and the noblest quarry that was ever landed by royal skill lay gasping and quivering in their midst.

"Bravely done!" they murmured all, with suppressed enthusiasm.

Then the considerate marquis attended his exhausted and supperless wife to her apartments on the scow, and in due time that mighty salmon was laid out in state, with the hook and leader still hanging to its jaw, and so was sent home to England as a present to her majesty the queen, and an enviable trophy from her loving daughter and royal highness, the Princess Louise. 


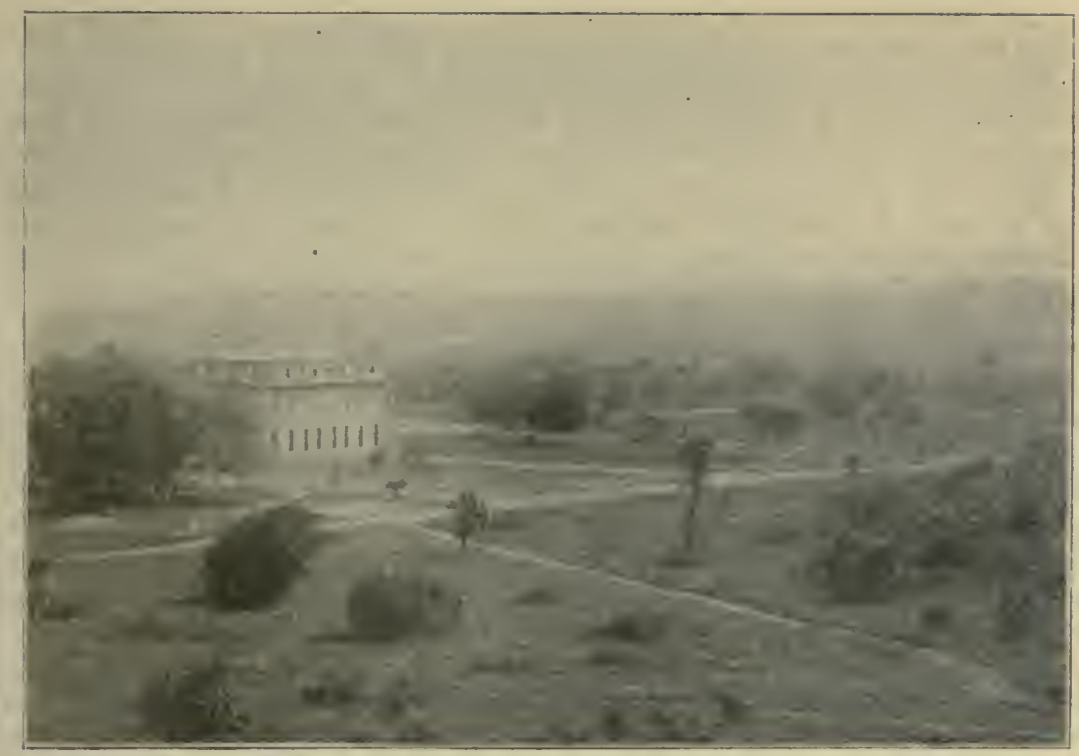

FORT GEORGE ISLAND HOTEL,

Two miles from Pilot Town, Mouth St. John's River. 


\section{CHAPTER XIV.}

TROUTING ON LONG ISLAND-OPENING OF THE SEASON.

ON Long Island the first day of March has long been regarded by the sporting fraternity as the opening day of the trouting season. The temperature is warmer there than in the interior, and the snow-water runs out from the streams nearly a month earlier. The fish are in good condition, active, constantly on the lookout, and supposed to be eager to retaste the remembered pleasures of last year's fly-time.

The piscatorial experts and professional fly fishers of New York seem to regard it as important that this season should be opened in due form as the bishop does that the church should be formally consecrated. They also deem it incumbent upon themselves to be present to wet the first line, just as fashionable young ladies must wear the first bonnet of the new style. Accordingly, on this momentous first of March (or rather, the day before), the afternoon train of the Long Island Railroad is almost monopolized by sporting gentry in full panoply of approved jacket and capacious boots, and armed with rods, creels and mysterious leather cases and bags of divers shapes and sizes.

\section{A FISHING PARTY.}

They are generally men of middle age, of the rotund and jolly pattern, ventripotential, who crack loud jokes and laugh from the depths of the stomach. Those with the ruddiest noses and smoothest faces are generally addressed familiarly as "judge;" others, heavily bearded, are ostensibly dubbed "general" or "colonel" by" the younger and less distinguished of the party, who have no titles to the universal admiration.and nudging approval of the country people in the car. However, on such occasions the distinctions of caste are all obliterated by the wicked flasks that equalize and level.

This sporting party is of goodly and genteel material. It has this reputation. It is the aristocratic cream of the universal community of sportsmen. Many of them are strangers to each other, inasmuch as they belong to different "clubs" that are scattered along the whole Atlantic coast of the island. These clubs vary in their number of members from a half dozen to four-score, paying for special fishing privileges in private ponds and premises. There are no localities where the public can fish indiscriminately and without restraint, except upon the spongy marshes where the salt tide-water flows into the creeks; and even here goodly fares of trout have been taken by inexperts. Some of the ponds are owned by wealthy retired merchants, and accessible only to a few particular friends. Others, not so well stocked, are the property of small farmers who are but too well pleased at the opportunity of profit from the leasing of the fishing privileges.

These few facts being ascertained, it is easily explained why, as the railway train goes on its journey, parties of two and three or half a dozen get out from time to time at the succeeding stations. These invariably find wagons in waiting, and are immediately rattled off to the seaboard over four miles of barrens.

The party in present interest consisted of four persons. Four is an agreeable number; it makes a table at whist, a quartet in music, and a party to a duel. The biggest man, corporeally, was a skillful wirepuller of wide reputation in the pisca- 
torial circle-a man of "infinite jest" and unbounded stomach, into whose mediterranean mouth good things perpetually flowed, and out of which better came. There is a classical dignity, a patronizing air about his fashion of whipping in a trout that would make the earliest of gudgeons gracefully acknowledge the compliment of being caught by him. The second in order was a thin, wiry fellow-a sort of piscatory assassin, a professional dealer in treasons, strategems and spoils, and a doctrinal believer in the efficacy of immense boots for beguiling trout. There are some fishermen who would consider boots that came to their hips indispensable, even if they were going to fish in the dry bed of a stream. The third resembled a certain celebrated member of an ancient party that included several fishermen, inasmuch as he had an eye to the wants of others and bore the provender bag for them. The fourth was the subscriber, of whom the less said the better.

\section{GOING TO THE FISHING GROUNDS.}

You should have seen this lively quartet as it gathered at the depot on the afternoon preceding that Friday, 1st of March-unlucky day, but suggestive of fish nevertheless. There was no trace of undue excitement upon their faces. One would scarcely have suspected that a weight of cares rested upon their shoulders and that their next day's happiness depended upon the solution of muddy geometrical problems and juxtaposition of lines, angles and punts. What a convenient affair a railroad is! New Yorkers would hardly think of going down Long Island for trout, except for the railroad. Nay, as for time and distance, it might be said that one can almost sit in his chamber at Brooklyn and fish in the ponds at Islip, sixty miles away. So we have hardly taken our seat in the cars, selected our flies, wet our whistles and smoked before we are set down at $\longrightarrow$, where Brock's team is in waiting, according to program. If you ever wish to go fishing, arrange with this same Brock the day before, and he will hold himself in readiness to take you over the barrens to the fishing grounds, as he did us. Only I hope it won't rain as it did on that unlucky occasion, and I trust you may have a spring wagon, so that betwixt the agueish chills of the atmosphere and the jolting over the scrub oak roots in the roads, you won't rattle all the gold filling out of your teeth at once. The torture was brief, however, for the horses made up in speed what they lacked in comeliness, and away we clattered, until luggage, fishing-rods, horse blankets, baskets, seats and passengers were well shaken into a heap over the forward axle.

In this mixed condition we were suddenly rounded to (as the sailors say) before the door of a goodly farmhouse, with a whirl that whisked the mud over the outer wheels, and had the good fortune to reach its protecting porch just as the soggy clouds had squeezed out their last drop of rain. As we unbundled, Uncle Sam Ketcham waved his hand hospitably at the door, while his bashful daughter Susan (we learned that her name was Susan afterwards) welcomed us with her sunniest smile from behind the old man's shoulder, like a ray of sunrise gleaming over a hill. A good old matron in silver-bowed spectacles and cap asked if we were wet, and our fat friend answered dismally for the party that we were very "dry." Then we hastily shook the kinks out of our legs, and after a "hands all round" bestowed ourselves for the evening.

\section{A TROUT BREAKFAST.}

Early in the misty, musty morning following the war-cry was sounded, and the party vaulted the nearest fence for a two hours' angling before breakfast. Uncle Sam, with an attendant carrying oars, led the way to the pond. The signs 
did not look promising for fly-fishing. However, after persistent lashing of the surface, sufficient trout were taken to give a taste all around; then we returned. A grateful odor soon arose from the frying-pan, and the cloth was laid. If the early exercise had not made us ravenous, the clean linen and the luscious comestibles that steamed upon the table, prepared by Susan's own skillful hand, would of themselves have provoked an appetite. Ah! Messrs. Editors, if you would have trout cooked as tront should be; if you would have them done to a turn; if you would have them broiled, baked, fried crisp and brown, done in bread crumbs, or served in any other style that tickles the palate or provokes the appetite; if you would have the delicious fish unfolded in rich pink flakes like the petals of a blush rose, which, dexterously lifted with your knife-point, reveals the trout's backbone as white and shining as the pearly teeth of an Indian princess; then, oh then, go to Susan! I know not what her other qualifications may be. She is good looking certainly. She is attentive to your wants, and obliging. She may make a capital wife for some wayfaring sportsman. But if she have none of the attributes which go to make man blessed, she can at least cook trout. If you wish just such a fine mess of trout, Mr. Edifor, just drop them (the trout) a line, as I have done, and if you don't receive an answer, prompt and decisive, you deserve to be beaten with your own rod.

\section{TROUT FISHING.}

After breakfast the piscatorial assassin in big boots wished to try his luck in the stream that formed the outlet of the pond; so the party was divided, we two choosing the stream and the others the boats.. It was not one of those streams that go laughing and rippling under branches of trees, gurgling through grassy meadows, eddying around huge prone logs, and murmuring under the alders; but it would a somewhat sluggish and tortuous coarse through the brown and sloppy mud flats to the ocean. There is a great deal in the surronindings and associations that make trout fishing exciting and fascinating. To cast your eye over the brink and watch your fly as it dances on the edge of a silvery ripple; to catch the sharp gleam of light just beneath, and feel a sharp tug on the instant thrill through the veins like the spark from a galvanic battery; to experience the peculiar sensation of that electric current as it flashes along your spine to the toes; this is the ecstacy-the primary delight of trout fishing.

Next comes the sport (if the fish be a large one) of leading him tenderly through all the intricate windings and avenues of his expiring agony, until you have landed him drowned safely in your creel. I cannot swear, Mr. Editor, that the trout feels precisely the same delights in the same degree. that you-I mean that anglers-do, but he has doubtless some feeling in the matter. If it is not pain he feels he certainly shows every symptom of astonishment, to say the least. Then he invariably gives a dying struggle or two in the basket at your side by way of admonition-you can hardly determine whether it be a twinge of conscience or another bite at the end of your line. If undubitably the latter, conscience is instantly unheeded, and you address all your faculties to the task of filling your creel and killing the biggest fish.

Whatever my friend of the capacious boots may think, I do not call it sport to stand in ice water up to one's hips and grow blue and numb with cold, while we beat the surface with the regular swing of a pendulum, scarcely tempting a single rise. Once I struck a fine large fish, and for a few moments enjoyed him well. He was an active fellow, and for a while it seemed a draw game between us. At last I had him alongside and passive, as I believed. The bank was steep, 
and, as I had no landing net, I brought him to the edge and carefully passed my thumb and finger down the gut to seize his gill. The chances were even then. It was a mere flip of a copper between us; but just as I thought I had him he "turned tail," and I lost. Disgusted, I drew my chilled limbs up the bank and returned to warm fire and hot toddy at the house. After a while I returned to the scene of action again. The others had come down from the pond to ascertain Boots' luck. Boots was still intent on piscatory pursuits, standing deep in the icewater. No wonder he went home with a cold! He had taken a half dozen. The fat member I found snugly ensconced in an adjacent cock of salt hay, philosophically smoking. The other I could not see, but I heard him hooting forth some doleful salutations as a signal of recall to a late dinner.

Linited space forbids any further details of personal adventure. Those who kept sacred the opening day of the season in different localities met varying success, but poor at the best. There was a general jollification all around within doors. This was pleasant. But if I wished for fullness of enjoyment in trout fishing, I should hereafter select some other day than the first of March.

Хоте. - The foregoing chapter was written by Mr. Hallock in 1867 , and gives a fine pen picture of trouting on old Long Island nearly fifty years ago.-EDitor. 


\section{CHAPTER XV.}

\section{AMERICAN ANGLING LITERATURE.}

THE history of angling literature in America is not difficult to trace for one who has clasped hands with those who were sponsers at its christening, and has had the good fortune to know personally almost every author of note since the era of angling books began; but to do full justice to each one, and to apportion to each the part he has borne, and the good he has done, is a difficult task, likely to become invidious. There are many exceedingly valuable contributors to the general fund of information in the several departments of ichthyology, who do not appear as authors, and there are comparatively few authors who write on the basis of their own personal observations and experience, trusting rather to the statements of accepted authorities to insure accuracy for their publications, and give them the requisite backbone. My preference would be not to laud the popular author so much as to designate such as have been able to contribute any thing at all to the sum total of knowledge, and to an intelligent comprehension of the fishes of the country. There was a time when a printed volume was the emanation or expression of a mind which was master of its subject, and its opinions were entitled to respect as those of one speaking by authority, and not as the scribes; but, nowadays, well-as Joel Penman pertinently remarks, "Any fule kin rite a buke!"

There is no end to the literature of angling. One is amazed at its redundancy. Everyone who goes a-fishing must needs tell of it in the sporting papers, if not in more pretentious publications. Their manifold collective utterances are like the chattering of blackbirds in spring, joyful but vapid; yet they include a fair proportion of monographs and random field notes, which, in the aggregate, form an exceedingly valuable compendium of ichthyological research. Much of this class of materials has been already collated and compiled by the collaboraters of the Smithsonian Institution into several illustrated quarto volumes, entitled "Fisheries Industries of the United States." The full statistics of the past having been brought down to date, and the work thoroughly systematized, it will be prosecuted to the end of time, as long as fish swim and Congressional appropriations can be voted for collection and printing. The steps progressive toward the ultimate accomplishment may be partially outlined in the brief synopsis which follows.

In earliest Colonial times, the reports sent to the Home Governments from New England, Virginia, and Florida included a fair description or enumeration of the ichthyofauna of the Atlantic and Gulf coasts; and, as the population gradually spread towards the Ohio river and the Great Lakes, interest was continually kept alive by the multiplying forms which were discovered. Angling was sometimes practised by gentlemen of leisure, as we discover from a musty little volume printed in Philadelphia in 1830, and most interesting it is, too-which gives the "Memoirs of the Schuylkill Fishing Club" from 1732 to 1830 . Such a diary, extending over a period of nearly one hundred years, must be without a parallel in any land. The subsequent occupation and development of the country opened out an immense and abounding field for the angler and his inseparable associates, 
the commercial fishermen and the naturalist-a fact which Englishmen, who are always toremost in such matters, were not slow to discover and avail themselves of. British officers stationed in the provinces were able to enjoy exclusively the delights of the Canadian salmon streams for half a century at least before the unsophisticated settlers or their neighbors in the States were even aware of their existence. Quietly they tossed the "Kippurns," or what-not, into the sequestered pools of a primitive wilderness, and were not envied or disturbed, because. forsooth, their sports were not appreciated or understood. This anomaly of tastes and pastimes can be explained. $U_{p}$ to forty years ago Americans were too busy to wile away time in fishing. They had not accumulated the "piles" which now make millionaires as plenty as blackberries; indeed, they hardly knew a salmon or trout by sight. If they wanted sport, they naturally turned to hunting. The gun and the chase were incidental to their everyday associations and employment of subduing the forest and driving pioneer stakes. And so it happened in respect to the primitive literature of this new country, that many topical books appeared on the dog, gun, and saddle, bear hunting, trapping, buffalo running, Indian fighting, and the like, but none at all on angling.

Once in a while a contemplative author like Thoreau, sauntering by the river side, or Willis, from "Under a Bridge," or Prime in "Owl Creek Cabin Letters,". or Ik Marvel, wrapt in "Reveries," would lead us unsuspectingly into secluded by-paths of the forest, discanting piously upon the silvery denizens of the brooks in a fashion to prompt an occasional vacation rambler to go a-fishing. But these new men (novi homines) in the days of their novitiate, never aspired to higher game than the "trout in speckled pride." The way in which they held him up to tender recognition might make a sentimental person wish to fondle, but never to skin and eat him. Prime, good master, was adolescent then and callow, but he was a born angler, well versed in the mysteries of the brooks; and, as soon as ever his heart was hardened and he ceased to regard the beautiful things as pets, he began to write bravely of kidnapping them from their fluvial home and "playing them scientifically." and so has continued to write for forty years, though he has never risen to the higher plane of the salmon. I suppose that the undisputed pioneer of American Anglishing Literature, pure and undefiled, is Charles Lanman, who came as one crying in the wilderness, as early as 1848, when he printed (in London) his "Adventures of a Salmon Angler in Canada." The same book was issued contemporaneously in America as a "Tour of the Saguenay." His subsequent wanderings by lake and river were woven into a double octavo volume of most entertaining sketches, under the title of "Adventures in the Wilds of America," printed in 1856. He has no peer among his countrymen. Surely it was no kid-glove excursion to go salmon fishing here before the era of railroads, clubs, culexifuge, and all that, though the chap who daintily airs his latter day experience seems as much of a "feller" as the man who took it in the rough before the lad was born. No doubt the memory of the Rev. John Todd has passed away with his corporeal taking-off, yet he was a companion of Audubon, and wrote "Long Lake" in 1850, a volume which embodied the first oracular utterances from the Adirondack Woods. And there was the Rev. Dr. Bethune, who edited a volume of Walton in 1848 , or thereabouts; he knew the intricacies of the Maine forests and the haunts of the mysterious land-locked salmon for forty years before the scientists determined what it was. It seems but yesterday since I knew them all-indeed, Lanman and Prime are still living and hearty.

Although I write of pastime, I would not detract one iota from the meed of 
praise which belongs to those progressive men in the early decades of the present century, who blazed a warpath into the fallow field of New World ichthyic science. There were Lewis and Clark, partners in exploration beyond the Rockies, who discovered the mountain trout and whitefish in 1809; Rafinesque, whose synoptical report of the "Fishes of the Ohio River and Its Tributaries," printed in 1820, was the first American publication in the interest of ichthyology; Dr. Kirtland, who followed with his "Fishes of the Ohio," in 1828; Professor Edward Hitchcock, on "Massachusetts Fishes," in 1835 ; Storer, on the "Ichthyology of Massachusetts," in 1839; Agassiz, on the "Embryology of the Salmon," in 1842; De Kay, on "Fishes of New York," admirably jllustrated with plates, in 1842; Storer, on "Fishes of North America," in 1846, an ambitious, but really comprehensive, work; and, finally, a general treatise on "Fish Culture," by Theodatus Garlick, in 1848. These admirahle text-books furnished a sufficient groundwork for intelligent prosecution of the study, and no doubt stimulated the pursuit of angling, for thenceforward angling books appeared in gradually increasing numbers, the field broadening as the area of the country extended. English publications, which had hitherto served as the angler's vade mecum, began to be discarded, or they were revamped and adapted to what gradually came to be discovered as American wants and American ideas. Such were Smith's "Observations on Angling," printed in 1833; the "American Angler's Guide," printed in 1846: Bethunc's "IValton," in 1848: and Frank Forester's "Fish and Fishing," in 1819. The first strictly indigenous native American book was John G. Brown's "Angler's Guide," which appeared in 1849. It marked a new era. But Brown was only a poor tackle maker, without classical education or social position, and how should he be expected to know anything? The critics rated him unmercifully. Nevertheless, his was a very complete and trustworthy guide to salt and fresh water fishing for the time, and well illustrated. Yet we are surprised to note its deficiencies. There is not a word about Canadian salmon, or grayling, or striped bass, or the fifty other principal kinds of fish which afford sport now. Fly fishing itself was then a new art. Up to 1815 it was scarcely known, and little practiced. Americans never knew how to fish for salmon until 1850 . Lanman was the only angler among them who had been initiated, and he was not proficient. A meagre twelve lines on page eighty is all that Frank Forester devotes to salmon in America, and Forester was thought to be an advanced writer.

I have said that Englishmen were foremost to discover the unusual attractions of our virgin salmon streams. So also they were the first to divulge them to the world in books. One by one those who had fished began to reveal the secrets of the primeval penctralia into which they had ventured years before. "Chiploquorgan," by Capt. Dashwood, and "Forest Life in Acadia," by Capt. Hardy, both British officers, printed in 1858, are incomparable sketches of scenes which no hearth rug knight of the quill would dare attcmpt to portray. "L'Acadie," a London book printed in 1849, is a delightful idyl of the Canadian woods. Latrobe's "Rambles in North America" (1835) contains something about fishing. Though of materials essentially American, these books were English in sentiment and emotion. They lack the amour propre of one who "treads his native heath." Long we have waited for such a book, but I doubt if it has ever yet been written.

In 1850 the indefatigable Storer, of Massachusetts, wrote up the "Fishes of Nova Scotia and Labrador." Dr. Gilpin, Matthew Jones, of Halifax, U. S., and Rev. M. Harvey, of Newfoundland, were also industrious pamphleteers. In 1852 Girard published his "Fresh Water Fishes of North America." In 1855 the 
ichthyology of the northwest was fairly covered by Dr. Suckley, U. S. A., in thę "Pacific Railroad Reports." Moses Parley printed his "Fisheries of New Brunswick" in 1862. In the same year Holbrook's ambitious work on the "Fishes of South Carolina" appeared-a large quarto, with colored portraits of the fishes described. The civil war broke out before the work was finshed, and the subsequent death of the author precluded its continuance. In 1866 Lord's "Naturalist in British Columbia" was published. Other books, of more or less interest to the angler, appeared from time to time, but none of special value. Nothing like a comprehensive manual was published until 1864, when Roosevelt's "Game Fish of the North" came out. That was during the year of the first lease of a Canadian salmon river, the Nepissiguit, and the book made special reference to that famous stream in its chapter on salmon fishing, itself a new revelation to the fraternity of fishermen. How to fish for salmon, and the implements to be used, and a description of the sport, had never been presented before. The volume was a godsend to anglers, for it included the technology of angling, flyfishing, tackle-making, entomology, fish culture, camping out, etc. It described new devices, new methods, and new fields of sport, which had come into use during the sixteen years that had intervened since the enterprising Browne had prepared his "Angler's 'Guide." Moreover, it introduced new species of fishes, not previously regarded for sport, and identified others which had been in doubt. The whole subject was in chaos at that time, scientifically considered. Experts had not even quite determined whether a brook trout and a samlet (parr) were the same, or that brook trout were not, in fact, immature salmon. The world has moved since then.

In 1865, the year following, Roosevelt put out a supplementary book, entitled "Superior Fishing," relating chiefly to the fishes of the Great Lakes, and touching the lately mooted subject of fish protection. The two books together covered the common brook trout, the sea trout, the salmon, landlocked salmon, the coregoni group, the common carp, the mascalonge, pickerel, and great northern pike (now known as the Mississippi mascalonge, in distinction from the mascalonge of the St. Lawrence system), the two then scarcely recognized varieties of black bass, the rock bass, yellow perch, pike perch or wall-eye, the great lake trout (namaycush), lake trout, and siscowet, all of them fresh-water fish; and the blue fisl, striped bass. Spanish mackerel, and snapping mackerel (which has since been identified as a young bluefish), all salt-water fish-twenty-one varieties all told. The same year "Uncle" Thad Norris produced his "American Angler's Book," a magnificent illustrated octavo of 700 pages (distinctively American, and no mistaking its type). of the same general character and scope as Mr. Roosevelt's dual publication. and including descriptions of some fifty varieties of fishes, of which sixteen were salt-water forms; but with the disadvantage of being not always accurate. The anthor was somewhat "mixed" in his ichthyology, and liable to describe without having seen. His carelessness in these respects drew upon himself the gentle reprehension of certain professional Canadians, which he had the good sense to receive graciously, and print in an appendix to later editions. For the most part, however, the book can be relied on, and is serviceable. In 1869, Genio C. Scott, an expert in trout and striped bass fishing, printed a copiously illustrated octavo volume, entitled "Fishing in American Waters," which is open to the same objections as Norris's Book, only more so. He devoted large space to salt-water fish, with many of which he was well acquainted, and would have made a first-class book had he not prospected beyond 
his depth. By this time, too, science had made considerable progress, so that his errors became the more glaring. The praiseworthy quality about Roosevelt is that he seldom makes mistakes.

The same year Mr. Allerton described the monster trout of Maine, which have been caught of 18 -pound weight, in a very creditable book with the rather general title of "Brook Trout Fishing." There were other readable books of the generic type, some of them having high literary merit (Dawson's "Pleasures of Angling" being one of them, and Dr. Updegraff's "Bodines" another), but whose specific value consisted in the acquaintance they made with new resorts, such as the Adirondacks (Headley, 1856), the White Mountains (Prime, 1867), the Delaware. Waters (Krider, 1853), the Blue Ridge of Virginia (Strother, 1856), the Magog District of Canada (1867), the Upper Mississippi (Oliver Gibbs, 1869), and Carolina Sports (Elliott). Bertram's "Harvest of the Sea" (1866) was valuable to naturalists, containing much new information about Florida fishes. By the close of the decade fish culture attracted increased attention, and we therefore note sundry books on that subject, to wit: "Artificial Fish Breeding," by Fry (1866); "Fish Culture for Shad, Salmon, etc." (1868) ; "Directions for Raising Trout" (Stone, 1868), "Domesticated Trout" (1872), by the same author; and "Trout Culture," by Slack (1872). Perhaps a full bibliography of American books to the date last named will assist the collector and interest the reader, in spite of the partial recapitulation, and I therefore venture to interpolate it here as a sort of relay house on our historical tour. I claim it as the most perfect list yet printed:

Rafinesque-Ohio River and Tributaries... 1820

Fishes of Ohio, Kirtland............ 1828

Memoirs of Schuylkill Fishing Club from

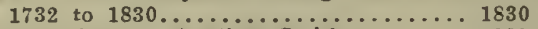

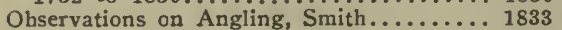

Massachusetts Fishes. Hitchcock........ 1835

Rambles in North America, Latrobe...... 1835

Ichthyology of Massachusetts, Storer...... 1839

Embroyology of the Salmon, Agassiz...... 1842

Fishes of New York, De Kay......... 1842

American Angler's Guide, Brown........ 1846

Fishes of North America, Storer......... 1846

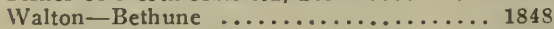

Fish Culture, Garlick................ 184

Adventures of an Angler in Canada; Tour

of the Saguenay, Lanman.......... 1848

Owl Creek Cabin Letters, Prime.......... 1848

L'Acadie (London).................. 1849

Fish and Fishing, Forester........... 1849

American Angler's Guide, J. J. Brown.... 1849

American Sportsman, Lewis........... 1850

Fisher's Manual for the United States.... 1850

Long Lake. Todd.................. 1850

With Hook and Line, Forester.......... 1851

Fresh-Water Fishes of North America,

Girard ....................... 1852

Old House by the River, Prime......... 1853

Sporting Anecdotes, Klapp-Krider....... 1853

Blackwater Chronicle, Strother........... 1853

Hills. Lakes and Streams, Hammond...... 1854

Pacific R. R. Reports, Suckley.......... 1855
Wet Days at Edgewood, G. K. Marvel.... 1855

Virginia Illustrated, Strother.......... 1856

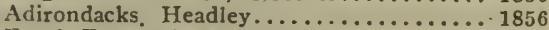

Frank Forester's Manual.............. 1857 Hudson Bay, or Every-day $\mathrm{Life}$ in the

Wilds of North America.............. 1858 St. Lawrence and Its Tributaries, Hattle.. 1859 Carolina Sports, Elliott............... 1859 Salmon Fishing in Canada, Hamilton........ 1860 Fisheries of New Brunswick, Perley...... 1862 Fishes of South Carolina, Holbrook....... 1862 Game Fish of the North, Roosevelt....... 1864 Arcadia (Northern New York)............ 1864 American Angler's Book, Norris........... 1865 Shooting and Fishlng, Reroil............ 1865 Superiar Fishing, Roosevelt....................... 1865 Naturalist in British Columbia, Lord...... 1866 Artificial Fish Breeding. Fry.............. 1866 Later Years' Fishing, Prime.............. 1867

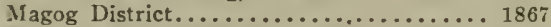

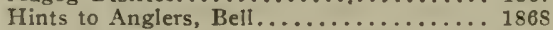

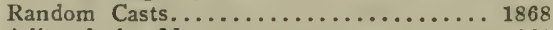

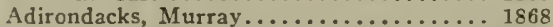

Directions for Raising Trout, Stone...... 1868 Lake Pepin Fish Chowder, Gibbs......... 1869

Brook Trout Fishing, Allerton......... 1869 Fishing in American Waters, Scott......... 1869 Forest Life in Acadie, Hardy.......... 1869 Chiploquorgan, Dashwood............. 1871 Trout Culture, Slack.............. 1872 Domesticated Trout. Stone............. 1873

Hallock's "Fishing Tourist" appeared in 1873. It was chiefly a record of personal observation and travel, which covered all the trout and salmon waters of the Continent, including the Pacific Coast. It introduced the Michigan grayling, which thenceforward became such a popular game fish that it was well 
nigh exterminated in the course of the succeeding ten years. In 1877 the same author, being editor of Forest and Stream at the time, printed the "Sportsman's Gazetteer," a volume of 900 pages, which became at once the standard reference book of American sportsmen. It was strictly an encyclopedia. It described and classified some three hundred varieties of salt and fresh-water fishes, giving their local names and synonyms, the first attempt ever made in a popular work. It included also a copious glossary of sporting terms, and a complete directory to all the sporting localities in each state, territory, and Canadian Province, by townships and counties, even to far off Alaska-a region whose ichthyology has since been treated at length by the same author in "Our New Alaska." The "Sportsman's Gazetteer" made the first classification of Pacific coast fishes, the same having been revised and verified by Professor Gill, whose scientific work plays such important part in advanced ichthyology. In 1878 Professor Gordan issued his "Manual of Vertebrates," a comprehensive and much needed work, fully up to the times. Ferguson's "Fishes of Maryland," and the annual reports of the thirty or more state fish commissioners, formed important accessions to the rapidly accumulating knowledge on fish subjects. Henshall's "Book of the Black Bass" (1881) was a special monography of great value. "Sport with the Rod and Gun" (1883) is deserving of mention as an elegant collocation of sketches, which combine vivid style with practical information. In the technology of angling four books have appeared during the past three years, which are quite thorough and comprehensive, and altogether indispensable to the practical angler. "Fishing with the Fly" (Orvis-Cheney, 1886) is illustrated with colored lithographs of salmon, bass, and trout flies, in no less than 143 popular and approved patterns. "Fly Rods and Tackle" (Wells, 1885) is a thoroughly American book of instruction, covering the entire field of angling mechanics in a masterful way, with drawings, diagrams, and demonstrations of perfunctory problems. The author is somewhat theoretical, and consequently dogmatic and arbitrary, a disposition which is made especially manifest in his more pretentious but less reliable book, "The American Salmon Angler." Old anglers accept as much of it as they can approve, and quietly reject the balance. A more thorough paced book, as a horseman might term it, is Keene's "Fishing Tackle" (1886). The author is an Englishman, resident in the United States, but equally at home in both countries, and altogether dispassionate and unprejudiced. He seems to have the happy faculty of a wise discrimination and judicious selection, rejecting whatever is bad in this or the other, and striving to combine hold fast, and recommend that which is good. "Fly-fishing and Fly-making" (1887), by the same author, is a sensible bok, which will suit the anglers of the old school. It endorses tried and approved methods, and is cautious of innovations. One very remarkable production, most creditable to its compiler, and certainly falling within the scope of legitimate angling literature, is the latest catalogue issued by Messrs. Abbey and Imrie, of New York, which contains some 1,500 illustrations. covering the entire range of angling outfits. Such an inimitable pictorial exposition is most useful in objective instruction, and ought to be catalogued in every angling library.

Included in miscellaneous angling literature are the copious and unremitting contributions to the weekly sporting papers, of which a single one, the American Angler, is devoted exclusively to fish and fishing. The redundancy of such material is amazing. It constitutes a sort of indispensable remplissage for om- 
nivorous demand, but its value is uncertain. " $\mathrm{X}$ " represents both its quantity and quality. An attempt to mention every writer of merit who has scratched his name with a fishbone on the illusive sand would make one tired; yet there is an indefatigable collector, Professor G. Brown Goode, the well-known chief of the U. S. National Museum, who has been compiling a bibliography of American ichthyology for the past ten years (!) and, although the product increases faster than he can garner, he hopes some day to corral the entire lot. His collocation will bring out prominently the names of noteworthy pioneers who are inseparable from early efforts, like Seth Green, Mather, Milner, Ainsworth, Hessel, Barnet Phillips, S. C. Clarke, Redding, Atkins, Brackett, Hudson, and a host of others, as well as the busy and more enlightened systematic workers of the present day like Bean, McDonald, Bendire, Earll, Ingersoll, Allen, True, et al, to the end of the long and distinguished list.

"Zoology of the Northwest" (1878), prepared by Lieut. Wheeler, is the title of the first of those ponderous volumes prepared under the auspices of the government, and now being issued from year to year, which are to render the labor of the future reviewer a pleasing task. It is an illustrated quarto, covering ground in part which had been imperfectly investigated by Dr. Suckley in 1855 . Gill's "Bibliography of Fishes" (1882), and his "Arrangement of Fishes" (1883) are scientifically important, and so is Jordan and Gilbert's "Synopsis of the Fishes of North America," which gives the nomenclature and descriptions of all known species of fishes north of the boundary between the United States and Mexico. It has a compass of 1,018 pages, and describes 23 orders, 172 families, 487 genera, 1,340 species, and over two thousand varieties of American fishes. Justly collossal, it stands like a mighty monolith at the very vestibule of the majestic Temple of Ichthus which is gradually taking form and dimension through the combined efforts of trained artificers and master workinen operating under the skillful direction of U. S. Fish Commissioner Baird.

This book of Jordan's is illustrative of a new era. It forms a preliminary part of the great cumulative work which it foreshadows and may perpetuate, and of which such elaborations as Goode's "Fishing Industries of the United States," illustrated with hundreds of plates, and the pioneer merely of a forthcoming series, and the annual "Bulletins of the U. S. Fishery Commission," and Baird's "Pacific Railroad Reports" and the "Fishes of the Eastern Coast of the United States from Greenland to Georgia," already stand out in conspicious proportions. Henceforth, the philology of angling is relegated to the poets, of whom the venerable Isaac McLellan, now living, and still singing at the age of eightythree, is almost the sole American representative. He and "Nessmuk" may chant their "Forest Runes" together in the porch of the Temple, and dillettante authors hang their garlands on the horns of its high altar, but science will henceforth be the reigning god and all the ichthic offerings be made to him alone. Knowledge is everything. . No angler may catch a fish without a Latin name, and all the arts, appliances, and methods of fishing will be contrived to that end. Nature and science will plod perpetually hand in hand over the classic boulevard, pari passu, trained to equal steps, while high upon the architrave, over the porch, appears in bold relief the cabalistic legend, alike suggestive of the impulse and incentive. Pisces in hoc signo vinces.

A continuation of the angling bibliography may here appropriately follow, concluding what has been begun. 


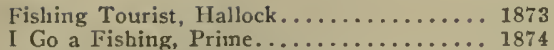

Camp Life in Florida, Ifallock......... 1876

Fishes of Maryland, Ferguson.......... 1876

Fish Ilatching and Fish Catching, by Roosevelt and Seth Green.............. 1876

Adirondacks, Wallace.............. 1876

Richardson and Rangeley Lakes, Farrar... 1876

Pleasures of Angling, Dawson........ 1876

Fur, Fin and Feather............. 1872-6

Sportsman's Gazetteer. Hallock......... 1877

V'acation Rambles in Michigan, Hallock.... 1877

Whitney's Pathfinder (Florida)......... 1877

Adirondack Tales Murray............ 1877

Northern Michigan, Leet.............. 1878

On the Elb. Hotchkiss.................. 1878

Adirondack IVilderness, WVarner......... 1878

How to Camp Out, Gould............. 1878

Moosehead Lake, Farrar................ 1878

Shooting, Boating and Fishing, WVarren... 187

Canoe and Camera. Steele.............. 1878

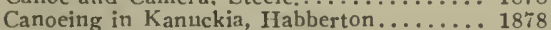

Manual of Vertebrates. Jordan.......... 1878

Trout Culture, Seth Green................. 1878

Zoology of the Northwest. Wheeler....... 1878

Voyage of the Paper Canoe, Bishop....... 1878

Four Months in a Sneak Box, Bisliop..... 1879

Flirtation Camp, Van Dyke (California)... 1881

Book of the Black Bass, Henshall........ 1881

In contemplating the varied brilliancy of the stars, I sometimes see a luminary cross the field of vision which is nearer and brighter than all the rest. It leaves a train of glory in its transit, which seems for the moment to eclipse all brightness, and while it blazes it excites the admiration of stolid gazers who are wont to regard the steadfast planets without emotion. Occasionally these asteriods occur in bewildering showers, so that all the firmament seems filled with scintillations of unwonted genius, and modest mortals hide their diminished heads. Then their light abruptly goes out, and the fixed white orbs gleam steadily as before. And so it is with books. The moral applies: Fame is a headstrong jade, and fickle. -London Field, July 11, 1887.
Bibliography of Fishes, Gill.......... 1882

Arrangement of Fishes, Gill........... 1883

Fisl, Prouty Rod and Gun............. 1883

Foster's Scientific Angler, IIarris...... 1883

Pacific R. R. Reports, Baird............ 1883

Pishes of the Eastern Coast, from Green-

land to Georgia................... 1883

Fishery Industries of the United States,

Goode ....................... 1884

Camping and Cruising in Florida, Henshall.. 1884

Woods and Lakes of Maine, Hubbard..... 1884

Fly Fishing in Maine, Stevens.......... 1884

Rod and Line in Colorado, France........ 1884

Fly Rods, Goode....................... 1885

Angler's Guide, Harris............... 1885

Bulletin of United States Fish Commission 1871-87

American Salmon Fisher. IVells......... 1886

Fishing with the Fly, Orvis-Cheney...... 1886

Fishing on the Brule, King (IVisconsin)... 1886

Fishing Tackle, Keene............. 1886

Fly Fishing and Fly Making, Keene..... 1887

Forest Runes, Nessnuk............. 1887

Fishes of Georgia, etc., Jordan.......... 1887
Synopsis of Fishes, Jordan............ 1883 


\title{
CHAPTER XVI.
}

\author{
A JUNE RISE ON THE GODBOUT.
}

Hon. Allan Gilmour, Scotchman, the hospitable laird of the Godbout river in lower Canada, who for thirty years has almost annually whipped its creamy waters for salmon, is dead. Let every mourner drop a stone. He fell asleep by the Lethe side at Ottawa last February, in the ripeness of years and full of honors, and now the pools will rest. His age was 79 .

Many were the honored guests among clergy, nobility and laymen who partook of his sumptuous bounty in the midsummer outings at the camp. He was superlative as a host, and as an angler peerless. No such doughty wielder of the two handed rod as he. His river record was never beaten. Bereavement falls upon the craftsmen heavily, like the penumbra of an eclipse. Life long friends lament him as a good man gone, jovial and companionable. The civic record says: "His name was associated with every good work in Ottawa, and his purse was always open to every benevolent and deserving cause."

Mr. Gilmour was a bachelor millionaire, domiciled with his nephew, John Manuel, who now inherits his possessions, and to a degree his proclivities and his worth. Of the many elegant private residences of the Dominion capital h1s was the most pretentious. It is located on the verge of the limestone cliff whose base is washed by the swirl of the Ridean Falls, and under the very aegis of the Parliament buildings whose clustering towers and aspiring dome overlook a great natural basin enclosed by circumvallant hills clothed with forest. This mansion has an aristocratic bearing of the Old World order. Lofty walls of stone and gates of iron enclose its servants' quarters. Palms, magnolias bananas, orchids, oleanders and other tropical plants flourish under glass. Heads of buffalo, moose, deer and caribou, and various trophies of the chase adorn the halls; and in the picture gallery is the finest collection of paintings in Canada, many of them purchased by the proprietor at great expense during extended travels in Europe and Africa, and fully one-third illustrating wild life on the remote frontiers of the Dominion. (One of these subject was reproduced recently as a reminiscence of the "Glassy Pool" on the Godbout).

From a terrace on the crest of a cliff a flight of 115 steps descends to a rustic boat-landing by the river margin beneath, where the famous steam yacht, "Cruiser," the hero of many adventurous voyages, sometimes lies; more luxurious in her appointments than Cleopatra's barge, more sumptuous than a Pullman palace car. She is eighty-five feet long, as staunch and steady in a sea-way as the great mail steamers; and I can fairly see her now, as I recall a former voyage, taking the combers of the St. Lawrence rapids in flying leaps as she speeds her way down river from Ottawa to Quebec, the starting point for the lower river, Morituri salutaris.

The events of fifteen years ago come back, dear, reader, as vividly as if no interval lay between; as if the grand old sportsman were not already dead and buried and wrapped in his winding sheet, stark and stiff. In my mind's eye I see him standing on the quarter deck, six feet four inches high in bodily presence, sniffing the first whiff of the salt sea air from the Gulf, as the bow of the sturdy craft dips into the whitening foam, buffeting the surges and throwing them aside as she 
bowls along. Such voyaging is the very ecstacy of exhillaration. And then the anticipation of the sport that is to come when we iget below and the salmon strike in.

As the late lamented Francis Francis of London Field writes in his rapturous "Sporting Sketches," all alive to the spirit of the occasion: "It is a strange thing how the very mention of salmon-fishing makes one prick up one's ears, and how the thought of it sends a sort of thrill through pulses grown old and torpid, and how, even when one is declining into the vale of years, the prospect of a week's good flailing in a well stocked, kindly dispositioned river sets one's spirit bounding and sparkling with delight. We chirrup and we sing. Very little makes us laugh, and jokes which would have been regarded at any other time as very small beer are now most excellent fooling. $\mathrm{Ha}$, ha! ho, ho! Cackle, cackle! Dash it all! I feel twenty years younger. By Jingo! I feel thirty years younger. I feel-I feel-jolly thirsty, old fellow-don't you? 'Pass the lotion. Here's health to man and death to fish!"

Gilmour's bon hommie was just the same. His Scotch humor was always at the fore, like the burgee of his yacht.

Very few yachtsmen make the tour of the lower St. Lawrence, though its salmon rivers are numerous. The distance is great; the channel intricate and beset with shoals, the scenery monotonous and depressing, and the expense heavy. Only at a few eligible locations along shore are signs of human life-here a fisherman's cabin and there a solitary post of the Hudson Bay Company. The north coast especially is for the most part bleak and forbidding desolation for hundreds of miles, and the only creatures that exist there are the weird birds which love the crags and the storm, the tumbling porpoises and the mysterious seals. From the abutting promontory which forms Cape Diamond at Quebec to the castellated rocks at Henley Harbor, near the eastern entrance of Belle Isle Strait, 800 miles away, there is an almost unbroken wall of granite, except where it is slashed by the impetuous streams which have cut their passage through its perpendicular face. These generally find their sources in lakes situated far back on the extended plateat above, from sixty to eighty miles away, and are mainly supplied by the melting of accumulated snows of protracted winters. Some of them, like the Montmorenci, near Quebec, pitch over an escarpment one hundred feet high or more. Others tumble to the sea in a series of falls and cascades, set back in the rock canons, which are over-topped by forested mountains, from which they emerge in varying moods of froth and eddy. Others again make their exit by an almost continuous rapid, like a sluiceway. Most of them are barricaded by insurmountable walls two or three miles above their mouths, so that the salmon cannot ascend. At the same time, such as present a continuous rapid, while they are most accessible to salmon are utterly impractible for the angler. The number which afford conditions suitable for both fishes and fisherman, that is, a succession of pools and rapids, either for a limited distance or throughout their whole length is appreciably small. The Godbout is the very best of then all, both for its scenic attractions and its comfort, and I shall never forget the sensation of feeling snug when, after four days' perils were passed, we ran in under the hospitable land and anchored out of the tide and the swell which rolled in from the Gulf. The "Cruiser" seemed to know her holding ground instinctively, and her anchor chain had hardly rattled out of the boxes when a school of grampuses began to spout and sport alongside, and the usual attachments of boobies and gannets swung out with cries and screams from the neighboring rocks to reconnoiter. At once Napoleon Comeau, the river guardian, came aboard from a little hamlet on the beach, and by dusk all the stores were on barges en route to the camp, two miles above. 
I doubt if there is any other extant or will ever be taken again, for these chronicles which I am writing are those of a private river and not of a club holding. While Gilmour lived, none but invited guests ever came, and of these only three to five at a time, for the Godbout was reckoned as only a three-rod river, that is, it afforded a complenent of fishing for only that many anglers, although there were no less than fourteen pools all told. And now that the proprietor is clead, who knows what changes and chances may betide?

Up river as seen from the "Cruiser's" deck, the vista opens most charmingly, disclosing an expansive amphitheatre inclosed by terraced hills clad with forests of spruce, with the river winding through and spreading out its shallows which are divided by pretty wooded islands. A zig-zag path climbs to the summit of the left promontory, where a flagstaff sixty feet high is planted, and a rustic sumner house affords rest and sllade. Looking seaward from this point of vantage, which is d conspicuous landmark to navigators fifteen miles away, there is an unbroken waste of water as far as the eye can reach, with here and there a vessel in the offing; and in the foreground great combers of "surf" roll in and chase each other over the sandy flats.

Multitudes of sea fowl hover over the landwash picking upon flotsam. On many of the higher elevations, landward, patches of snow can be seen, for June on the Godbout is no farther advanced than April in Montreal. The five cottages and all the outbuildings of the camp are in full view with half a dozen Castle-Connell cots or punts, aligned 11pon the beach in front. The largest of the cottages has a tower, with a chamber in the second story and a sky parlor in the third. On the ground floor are three chambers, a dining room and three bath rooms. Close by, the kitchen, ice house, fish house, etc. When the lord-proprietor arrives the Union Jack is hoisted on the tower, and at the close of the season it is housed again until the nex rolls round. To the gaffers and the denizens of the Nascoupie village at the anchorage bclow, it is the prime event of the year. Earthquakes and eclipses are nothing to it. Such a larder and luxurions appointments as the camp possesses, few anglers have ever seen; nor such an equipment of rods, reels, lines, flies, gaffs, wading stockings, weighing scales, score books and slates, face protectors, fly oil and the like. When summer finally breaks in, it usually does by the middle of June, the blackflies are "the very devil," and nothing in nature so much tries the angier's temper and patience. Can the mere novice imagine a person standing helpless for forty minutes, with both hands holding the rod, while he kills his fish, and the unconscionable insects attacking him on every exposed part of the body? No writer ever clid justice to the dilemma.

Gilmour used to say that there were no rivers in Scotland like the Godbout for "wickedness," and he always enjoyed testing the mettle of strangers. Killing and securing a salmon in a quiet stream is quite a different performance from bringing one to gaff in an impetuous rives like the Godbout, for there the labor is excessive, and the utmost tact is often required to save a fish. From its source to its mouth it is a turbulent stream, tumbling and careering through gloomy mountain gorges with a continuous pitch, and piling itself into billows of foam against huge bolders which obstruct its tortuous channels. It seems a marvel how the salmon can ever work their way to their spawning grounds in the upper stream.

The limits of the fishing is at what is called the "Upper Pool," where the long pent waters rush downward through a rock cut sixty feet deep with an impetuous discharge and spread out into a broad basin just under the shadow of an inpinging mountain. After whirling for a while in an inky eddy flecked with bubbles and 
foam, it jams itself against a confronting cliff, and then dashes off again as impetuously as before, though in a broader and more shallow channel. Below, the shores are nearly vertical all the way, fringed with trees. The bed is choked with boulders, and the air is damp with the spray which rises from the churning waters. It is whiteness all the way to the camp, save where temporary pauses are made at the pools, which I dare say are most acceptable and necessary halting places for the salmon in the tedious ascent. Following the bank of the river a path has been constructed through the woods with much difficulty and expense, so as to communicate with the pools which would otherwise have been inaccessible. Trees have been chopped away and rocks blasted out, hewn logs stretched across chasms, hollows filled up with stones and earth, hand rails placed where the brink is dizzy and the footing precarious, jetties of stone built up around projecting cliffs which bar the passage. Drinking cups are found at cold, wayside springs, which trickle down the moss-grown rocks. At two of the pools long ladders are laid over boulders in the foaming mid stream in order to reach to points of vantage for casting. At other pools punts are moored for special service there. At one place, halfway down the stream, a crossing is effected by a rope ferry, which traverses the foot of an angry rapid to a landing cut in the solid rock, whence an iron railing assists the ascent up the bank. The expense of all these aids and improvements was great. Surely here the luxury of salmon fishing must be enjoyed. And yet mishaps are numerous, and once Milford, the Earl of Dufferin himself got a ducking at the "shea." It is a "wicked" river.

Rivers are gauged as I have intimated, according to their capacity to afford good angling for a given number of rods. When a party is on a river, certain pools or divisions are assigned to each rod day by day, and these pools are fished in rotation so that all have equal chances. The run of salmon begins about the middle of June, though a few fish sometimes arrive earlier. They come in detachments with each tide, and an experienced hand can generally tell whether the arrival be large or small. In the early part of the season the rivers are very high from the melting of the snow, and back on the table lands, so that the lower pools afford good sport at low tide, but as the flood gradually subsides and diminishes in volume the lower pools within reach of tide water become useless because they are shallow at low tide and salt at high tide. In neither case will saimon take the fly. It is apparent that an early run is most desirable, for the river is then likely to be full with the spring flood, and the fishing range is much extended. Average weight of Godbout salmon is eleven pounds. In many other rivers it is double and over. However, it is a prolific river, the catch in one given year exceeding 500 fish to five rods, aggregating a weight of 5,200 pounds. 


\title{
CHAPTER XIII.
}

\author{
ANENT THE SALMON.
}

Ix casting about among the many angling books which have been written I discover that the literature of the salmon is for the most part painfully hackneyed. Every author is voiced alike. There is the same theme, similar treatment, and one uniform arrangement. Each book aspires to be a "complete" treatise, and every one is oracular. Classes are formed, the impresario comes to the front, and every scholar is expected to toe the mark. Then follow, by rote, the biology of the fish, his habits and characteristics, and "when, how and where to capture him," concluding with some wild anecdote or bit of poetry by way of a snapper. No detail is omitted. All the elements are presented. If any variation is attempted, it runs into the speculative and mysterious. The study becomes as classical and occult as Madame Blavatsky's theosophy. The ways of a salmon seem past finding out. The more abstruse and empirical the treatise is, the more eminent becomes the philosopher; and the stronger his "pull" on the credulity of his readers, the higher the price of the book and the wider the play of his fancies. Yet the guild of anglers has stood listening and entranced for eighteen centuries. Strange that so much inspiration can be drawn from a single string! But is it not time we had a new version?

I have lad faith that a master spirit might yet appear who would aerate the pool, and place limself in such perfect touch with his readers that when he leads one to the river side (in his mind), be it adept or novice, he will be able to imbue him with the full power of the subtle sentiment which animates the pastime of salmum fishing. By such quality he may evoke all the possibilities of the theme, and we shall have not only the intrinsic melody, but the full symphony. By some. sort of mental metathesis he wiil put his pupil in the place of himself. He will guide him to the swirling pool and point out the exact spot in the curl of the rapid where he shall toss his fly. He will act as mentor to him all the way through. precisely as if he were in bodily presence beside him-the only difference being that instead of jogging his elbow here and giving a timely hint there, the angler will be left entirely to the exercise of his own judgment and discretion when he comes to wield the wand. Given a manual of tactics for an infinite number of hypothetical situations, prescribing for each a process, and coupling whys with wherefores, and causes with effects, he will have full liberty to make his own selection of materials and methods. He pays his money for his information, and he takes his choice; only he may not be able to catch any fish! However, no writer that I know of, save one, has ever exhibited the rare faculty required to produce a true vade-mecum for the salmon fisher, and he, unfortunately for the craft, seldom airs his knowledge through the medium of cold type. If he only would put it to practical test? No one can afford to go salmon fishing nowadays unless he has a mint of money; and the man who does go has his object lessons right before him. What need has he of vooks when he can have realism? Substance is better than the semblance. And of what value are books to the multitude who are disbarred? Angling books have had their day. Nowadays the canoe-man does all the coaching. Very few salmon anglers undertake the rough work of the old school. They do not care to pit their 
mettle against the temper of what Scotchmen call "wicked rivers," where the capture of a heavy salmon is a test of true strategic cleverness and physical endurance rather than of mere mechanical manipulation. Most of their fishing is done from canoes or boats on glassy and streamy water, with two canoemen to handle the craft. They have spent fortunes to secure their rivers and equip their sumptuous cottages which have taken the place of primitive camps, and it has taken time and money to reach the delectable ground. They do not propose to work their passage leading the horse. Therefore, as has been stated, the boatmen do all the work. They carry the gentleman's rod and wraps and rubber cushion to the canoe by the river side, and make him snug on a seat amid-ships. Then they pole out to the middle of the stream or the most likely portion of the pool, which they all know like a book, and drop killick to hold the canoe in position. They suggest the most killing flies, for they are thoroughly posted by critical observation, and the angler makes up his cast accordingly, and pitches it at the spot to which he is directed. Boatmen instantly detect a novice, and thenceforward lose no tine in working their varnish. They show him how to cast properly, and how to pump the rod in order to attract the fish, and how to fasten to a rise. No person more able and ready to coach than they. Sometimes they will take the rod in hand themselves, and deliver the line in a way to astonish the tyro. If a fish fastens, they hand the rod back to the angler, then up killick at once and follow the fish with the boat, snubbing or humoring it according to its moods. These tactics amount to the play of an automatic reel, and the angler has only to keep the tip of his rod well up, except when the fish jumps; the boatmen "do the rest." If the fish jumps, the tip dips responsively. else the salmon will free himself. Each crew takes personal pride in the achievements of its canoe, and of the trophies it returns to the camp, all of which are credited to the patron of the boat, whoever kills them. Usually the boatmen tire the fish out in twenty minutes or so by skillful navigation, and gaff him alongside of the canoe; but if they have an experienced angler aboard, they will go ashore on occasion, keeping deferential silence from start to finish, and venturing no suggestion until the result transpires, when critical remarks are allowed to be in order.

The foregoing is the vogue on many rivers. Boats are used wherever they call be, because there are many pools or more properly swims which cannot otherwise be reacled. On rivers whose mid-channels are studded with boulders, ladders with boards are often laid out to the best casting stands, and from one point of vantage to another, so that an angler not especially expert in handling a salmon on the line. can do so with excellent chances of saving him by simply following the course of the ladders up and down the pools, as the fish may happen to lead hin. Canoes are generally used, but on the Godbout there are Castle Connell punts some twenty-six feet in length, which are very stiff and safe, even under the crucial test of the roughest water that any craft ought to venture into. On narrow rivers like the Jaquet and Charlo, which can be covered by a maximum length of cast, no boats are required, and on the Nepissiguit the channel pools are too strong and deep to be fished from canoes, and have to be reached from marginal rocks and ledges.

Of course the style of gaffing a salmon depends much upon whether the gaff is handled from a canoe, a shelving beach, or a steep ledge, and the length of handle varies accordingly. For the rocks it may be ten feet long, and the feat of getting a fish securely on the iron under such disadvantages is difficult indeed. Some anglers invariably beach their fish when they can; others prefer to gaff from the canoe. None choose the rocks. It is possible for the angler to gaff his own fish from boat or beach, but not from a vertical rock. Old anglers who have lad unfortunate 
experience with bunglers and lost many fish are chary of strange gillies, fur there 1s nothing more exasperating, after a forty minutes' tussle with a strong fish, than to have some slouch barely scratch him with the point of the iron as he wallops past an arm's length off, working up renewed energy which gives promise of a long continuation of the fight. However, one cannot always choose his own gaffing place. Gravel beeaches are not conveniently at hand on most rivers. Neither can an angler always keep out of the water when he fishes from the shore. Says one old veteran: "I never wade." Doubtless. But there are rivers where you would have to wade or swim to follow your fish. On such wild water a gaffer is indispensable.

One should never be in a hurry when he wishes to fix a fish on his iron. Put the gaff into the water as quietly as possible, and unobserved of the fish, to the depth of sixteen inches or so, and make the clip, point upward and inward, sharply, but without jerking, endeavoring to hook him just abaft the shoulders, which is the center of gravity. If hooked elsewhere in the body, the fish gets a big leverage with head or tail, and will make a ghastly rent in his flesh, if indeed he don't flop off altogether. Never strike a fish in the belly. Nothing is more unsightly than a great gaping wound, especially if the entrails protrude. I notice that a few old anglers have adopted a big landing net with a two-foot span, which has its advantages; but one would think it clumsy to handle, and likely to scare the fish. Veteran river men invariably carry a billet with which to whack the salmon on the head as soon as he is lifted out of the water. It gives him a speedy quietus and a better flavor when eaten. Moreover a thumping fish makes a hideous noise in the bottom of a boat, and scares other fish away. Few anglers think of this.

Lots of things are to be borne in nind when one goes salmon fishing. One object is the reel. Keep your eye on the drag, and don't let the line back-lash or overrun. An unexpected jerk on a line will do this and make mischief in an instant which an hour of labor will rot undo. "Striking" a salmon will lose oftener.than win. In general, a heavy salmon hooks himself by carrying down the fly in water which is curly, else he is not hooked at all. To strike a salmon on a taut line when well down stream would be fatal to tackle. An old angler simply lifts the tip of his rod gently, and so tightens the line at the proper instant. In dead water, or a back eddy, when the fly is well under the surface, smart stroke is not only admissible. but necessary. When to strike, how to strike and whether to strike at all, are questions of the moment, not to set precept. Categorically, the whole subject of salmon angling is one of varied and continued practice. An angler may fish the same river all his life with best success, and yet fail to kill on a different river until he has studied its different idiosyncracies. It is the intensely specific characteristics of rivers which makes salmon fishing a superlative art and the most difficult to master of all piscatory attainments. A doctor might as well undertake to diagnose one case by the symptoms of another as for one angler to judge of the temper of one river by that of another. The more we fish the more surely we discover this truism and its parallel. One cannot always judge character by physiognomy; we discover it by trial. The master hand may outline the rote and routine of an angler, but he cannot make an adept. Perhaps this is why an old hand is tempted to discard treatises. Fortunate he may, be if he is not compelled to hang up his rod now altogether. To the "contemplative angler," still robust and hearty, but poor in purse, it is misery to reflect that he must yield his pastime before his day is run. Rivers continue to flow, and the plash of the salmon is heard in the stream, but he may not fish; the priceless waters are open only to the few who can afford to buy. The willow wand is superseded by the golden rod. But what 
astounding sums these angling privileges command! Ten, twenty, thirty thousand dollars, and even more, for a few rods of river front with a bare fortnight's fishing per annum! To those who have enjoyed the freedom of the river, without money and without price, in years gone by, the changed condition of things seems strange, and the question naturally comes up: How has it all happened? Has the intense passion for salmon fishing, whose charms all the poets and anglers have sung from the days of Oppian to Bethune, at last reached fever heat? Or is it merely the pleasure of exclusive possession that enhances value?

I remember once coming down the Restigouche twenty odd years ago, and stopping at old man Merrill's over night, half way up the river. He occupied a small log cabin beside a splendid salmon pool, and lived a lonely life in a very humble

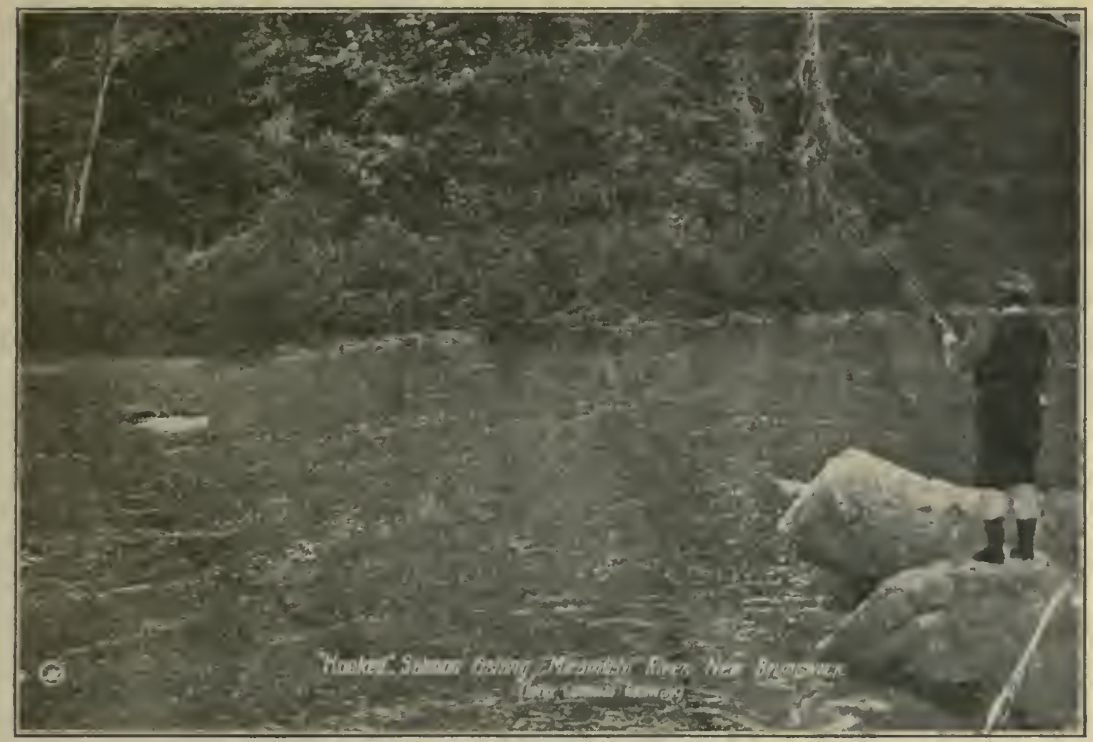

SALMON FISHING OX THE MIRAMICHI RIVER.

way. He was poor, but gathered no end of salmon during the season; indeed became a drug at his table, and a steady diet of the pink-hued fish for forty days would cloy his stomach. Wishing to do the handsome act for his guest at supper, he graciously set before me the best his larder afforded, in his estimation, which was a broiled smoked herring. This seemed to be the piece de resistance. No cooked salmon was in sight. I was hungry for a mess of the dainty fish, for I was fresh on the river myself, and for hours previously as the ever dipping paddles sped us down the stream, I had kept thinking: "At Merrill's we will have fresh salmon." However, I had no occasion to feel disappointed, for I had only to express myt desire and abundance soon appeared. I ate of the coveted viands to repletion, but old Merrill "allowed" that he had had so much of it all summer that he didn't think I would care for it. That seems to be the logic of the present status on the river. 


\section{CHAPTER XVII.}

CUME, LET US COMMUNE TOGETHER.

DeAr Oln ParD-The days when we touched elbows at the desk seen not long ago, so swiftly do the winged years fly; yet during that fleeting interval how many veterans of the old craft have gone out from among us, to meet no more by the sunny streams of earth! We shall see them no more until we gather at that shining shore, which is the boundary and beginning of a new life. For a little while, good friends, adieu! and joy be with you if ye stand among the blessed chosen!

I love to think of those dear old comrades, with many of whom I have tramped and camped a quarter of a century ago, even while their venerable heads had already begun to whiten; and I rejoice to feel that the pleasure of the retrospect is scarcely less satisfying than the pleasure of the hope which throws its gleam forward, even to the far-off portals of the heavenly arcana. The halo of their exit is hardly less radiant and beautiful than the pervading glory of the promise. "Blessed are the pure in heart." And who shall hereafter live to better illustrate by their pure lives and simple manners the goodness which so often germinates and thrives among the sinful rocks and tares?

Thanks be to the Creator who has so ordained the laws of nature that the longest and best lives are vouchsafed to those who find their chosen quest and pleasure in the open air! No tree of evil grows in the Eden of the angler; but vigor of mind, elasticity of limb, amiability of manner, loving kindness, contentment and healthful introspection cluster and hang like grateful fruit upon all the branches everywhere. Wherefore I am enabled to rejoice that so many of the old guard yet remain; that they still live to kindle new enthusiasm from the fire of the ancient altars, and enjoy with us their long accustomed pastime. The silver threads are already beginning to line your own brow, old pard, and your sturdy limbs don't give out the involuntary play they used to do; yet the afflatus within your bosom is as mighty as ever, and you have a consciousness which needs no quickening. The old monitor inside gives out as full, responsive and sonorous a sound as if it had not already swung within its weather-beaten belfry for three score years and ten! To us, who are sauntering through the valley, it is indeed delightful to hear "the ring of the true metal." May it chant the vespers for us, when finally, at eventide, we reach the still waters!

Now, you know how it is yourself-be a man never so old, he still can plod, and still can fish. Whatever other functions fail, this remains. An angler may outlive all his usefulness, but he can never outlive his longing for the old haunts, and the enjoyment of fishing, so long as he can sit in a boat and feel the nibbles, albeit his joints are too stiff to play the struggling captive home. And this is why I am constrained to write unto you, pard; and, when I see the familiar name of some member of the ancient brotherhood shine forth betimes in the columns of your journal, to say to them: "Come, let us commune together." You remember, once upon a time, long ago, "when we were first acquent," how the old guard used to gather at the rendezvous, and what a mighty corps of new recruits there was, and how they seemed entirely of one faith and one consanguinity, and how all 


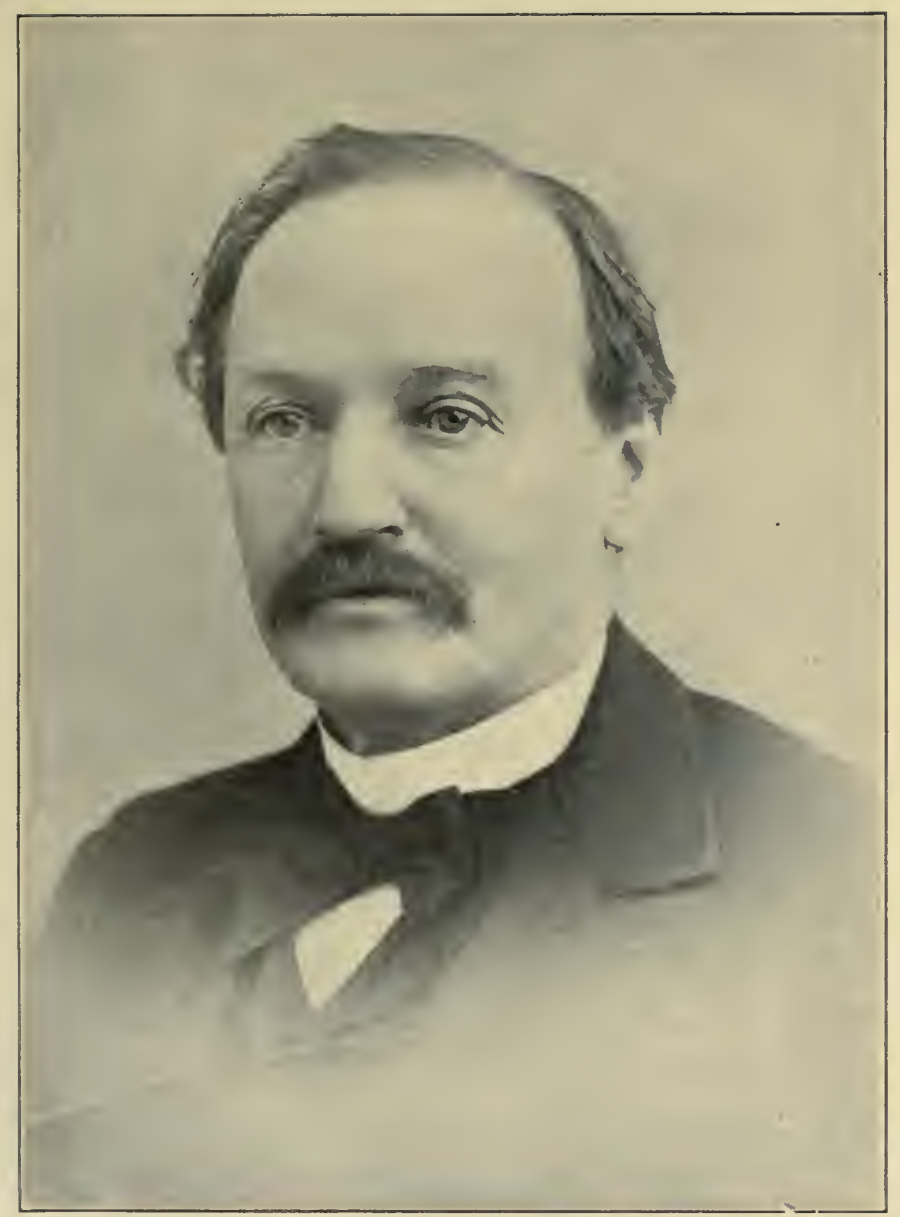

WILLIAM C. HARRIS,

EDITOR "AMERICAN ANGLER." 

listeners were entranced when another spoke? and how we fondly hoped the family circle would remain unbroken for all time? It was a glorious constellation of contributors, each of whom brought individual richness to the ingathering of the common stock. Well, a catastrophe befell, and the hive scattered, never to swarm again on the old camp ground. Some, as I have said, have passed from life, others perhaps are dead to new associations; yet I am indulging the earnest hope that those whose rames and faces were once familiar may be induced to gather once again around a common altar, inasmuch as the "Angler" has opened the way by which all may enter. It was a christian thought which prompted you to set up the Penates again that all may re-unite to kindle the sacred flame. One by one I have watched the old names re-appear, and gleam out like the shining orbs which herald the spangling of the firmament, and I have welcomed each in turn with the ferver of one who hails a beacon light in the gloom. First, came good old "Ned Buntline"- "may his years be long and end in peace;" then the ever-faithful gemini Isaac McLellan and "S. C. C." then the steadfast "Al Fresco," friends Rich. Sears, "W. T." and a dozen others who have earned three score years of honors. Where is the rest of the old guard? Where are the veterans Lanman, Conway, Logan, Mosely, Brackett, Kinney, "Ted Grayson," "Asa" and that genial author who wrote the "Pleasures of Angling?" (Who of us have not experienced them?) In the "American Angler" we have a rendezvous where all can meet-a campfire where all can toast their shins and string the "long bow"a sanctuary where the lovers of the gentle art may withdraw in quiet and close communion. Gentlemen it is not meet that we should live longer apart, and let the fires die out. Will you not renew the old love again? "Come, let us commune together!"

Pard, I salute you!

Charles Hallock.

NorE.-The foregoing fraternal greeting to a brother of the angle and the pen was written in 1882.-EDITOR.

THE TRIBE OF ESOX.

I have found very few anglers gifted with that nice perceptive faculty which enables the ichthyologist to distinguish between the several members of the esox family. Indeed, their distribution is so wide that it is difficult to obtain first specimens of each in juxtaposition. so as to compare them together. The habitat of the great northern pike is the Mississippi river and its tributaries, while the muscalonge is peculiar to the St. Lawrence and its tributaries. These are foundation data upon which I suppose it is proper to build distinctions. Pickerel (esox reticulatus) of maximum size are often confounded with esox lucius, while lucius is as often substituted for nobilior. All the written descriptions given by wellinformed fishermen seem to fail of practical utility in establishing conclusive distinctions when put to actual tests. It is only when the several fish are laid side by side that the fundamental differences become apparent. Some close observers go so far as to claim that there is a pike peculiar to Ohio river tributaries near their sources, which are confounded with both the northern pike and the St. Lawrence muscalonge. Recently, at the residence of Gen. Israel Garrard, in Minnesota, it was my good fortune to inspect some splendid specimens of these three alleged varieties, which the general discussed with all the critical acumen of a scientific enthusiast, and I accepted his points of discrimination with the ready acquiescence of a disbeliever who wishes to be convinced. I submit the following letter, written since the interview, which may throw some light "pon this vexed 
subject. You will note a reference made to a certain article which has appeared in the columns of The Angler, relating to this third species of pike, but which had escaped my notice. I quote what follows:

"Mr. Chardes Hallock:

"My DEAR SiF-I am sorry that I cannot refer you to the number of the American Angler containing notices of the 'Chautauqua Lake Pike,' also known as the 'Muskingum Pike.' and having its habitat in the tributaries of the Ohio. This is a pike that has not been fully recognized and described by sporting authorities, and I suppose for the reason that it has been generally called muscalonge, and confounded with that fish. I think that it should be named esox immaculatus, as the striking peculiarity of its appearance is the absence of markings or spots. This marks the difference between it and esox nobilior and esox lucius, as well as the reticulatus and fasciatus in a way that cannot be misunderstood. It is possible that its habitat is confined to the Mississippi and tributaries, but Roosevelt's account of a similar pike being found in waters of Cape Cod throws some doubt on this proposition. The texture of the flesh and its flavor gives it the highest rank among fresh water fishes. This perhaps cannot be said of any other of the esox family, not even the nobilior. I once saw a 28 -pound specimen in a Chicago fish market, and where, as I expected, it was called a muscalonge. I have seen several notices in the Pioneer Press of anglers bringing in muscalonge from Clear Lake, near Anoka, but have not had an opportunity of verifying their fish. A marked peculiarity of what I call esox immaculatus is the very small size of the scales.

I. GARRARD.

NoTE.-The foregoing was written in 1883 .

CUT-THROAT TROUT.

I went up the Rosebud Creek from the Crow Agency at Stillwater, Montana, in company with Agent McKeller and Clerk Charles H. Bostwick, on a trip to a delightful mountain lake which lies at the entrance of the Rosebud Cañon. The lake was a temporary reservoir or interruption of the foaming torrent, which rushes from a snow-capped mountain which alone shuts us out from the Yellowstone Park. The lake on one side was very deep, where the cliff went down plunb into the water. On the other side the bottom was shallow and sloping to a paddock of lily pads, which seemed to define the margin of deep water. It was an unvisited lake, and there was no boat. At the head of the lake the Rosebud tumbled in with a mighty rush of deep green waters over the boulders, and just where it debouched the liveliest trout fishing could be had. The fish averaged uniformly two pounds in weight, and could be caught as readily from one shore as the other, either in deep or shoal water. There were very few of a size below or above two pounds. I have never attempted to write up that trip because my pen could not do justice either to the sport or the marvelous scenery which we found there in the heart of the Rockies. I am moved to refer to it now only because we caught fish there which I have never seen on the same meridian or anywhere else. I have certainly watched angling reports ever since, in vain, to discover some description which applied. The trout resembled the iridea of Colorado in respect to the metallic black markings scattered like lustrous grains of course black powder over its shoulders and body; but it lacked the rainbow lateral stripe. Its distinctive feature, however, was a slash of intense carmine across each gill-cover, as large as my little finger. It was most striking. For lack of a better description we called them "cut-throat" trout. Have any of your correspondents taken any like them anywhere along the range?

Note.-Written in 1884 . 


\section{CHAPTER XIX.}

ARCTIC FISIIING IN SUB-TROPICAL WATERS.

New River, N. C., in latitude 35 degrees, never had such a chill in its whole fluvial history as it experienced last month. From the 9th to the 15th of February the morning temperature oscillated between ten and twenty degrees Fahrenheit, and great sheets of ice and schools of torpid fish were floating all over the surface. The greater proportion of these were sea trout (weak fish, of the marine family Sciacnidae), weighing from ten to twelve pounds apiece, but there were many small rock fish, besides a considerable variety of fresh-water pan fish. They were all so benumbed with cold that they could be lifted out of the water with the hands, and were practically within reach of all who chose to come and take them.

To the poor and unemployed the occasion was a Godsend, while every one else without distinction who could hire a boat or scow, or improvise a raft, went out fishing. Those who were industrious and well equipped made big fares, for the cold snap which pervaded the entire country from the Atlantic to the Pacific sent prices up two or three hundred per cent., and the local fish dealers and packers had to hump themselves to supply the great metropolitan markets. Ordinary business was suspended, labor could not be hired at any price, steamboat crews dallied on their regular trips and picked up hundreds. The big lumber mills at Jacksonville, at the head of navigation, which had been running gangs of 150 men day and night, were obliged to shut down because the saw logs froze up in the booms, and all went fishing. Trains from Newbern and Wilmington brought down a good many fishermen. One lad of fourteen years earned $\$ 32$ cash in two hours. One man caught 3,000 fish in five hours, which he sold to the dealers for $\$ 240$. The aggregate catch ran up to 50,000 fish. Regulation methods were discarded, while baskets, dip-nets, small seines, rakes, pitchforks and oyster tongs were brought into use. Dealers bought freely all that were offered. They did not so much mind enhanced prices because they could procure unlimited supplies of ice at the cost of gathering it from the rivers. Some boatmen earned three or four dollars a day at this work. Hundreds of tons were obtained in upstream waters where the rivers were frozen solid to the depth of three or four inches. These surfaces were covered with skaters of both sexes, and assumed a truly Minnesota appearance; orders for skates were sent north by telegram and returns were impatiently awaited, but the amateurs were in bad form and the execution below par. Such boreal phenomena are not likely to be repeated in a hundred years, unless the sunspots enlarge and the solar heat be minimized, for New River is not a fluvial freak subject to caprices of the frost king, but a legitimate ward of the "Sunny South" (so named in poesy), whose shores are clad with bright-leaved verdure the winter through, inviting picnics and siestas. Magnolias, holly, bay, myrtle and thirty other evergreens simulate the summer season, on those warm days when the haze and sunlight are upon it, and it is then that the visitor from the north is wont to write letters of condolence to those detained at home to shiver in frigid atmospheres. So much is one's enjoyment enhanced by meretricious contrasts and comparison.

From a point where the Wilmington, Newbern and Norfolk Railroad crosses the river, the stream follows a sinuous course through the woods for a couple of 
miles, with many a cove and pocket, where large black hass may be caught with bait, spoon, or bob of hair and feathers on almost any warm day througlout the year. It then brcaders into an exparsive estuary which averages three miles in width, and so continues for thirty miles seaward to Brown's Sound, whose brackish waters come up to mingle with the outfow of the uplard swamps. replenished diurnally by the ocean tides which flow in through the inlet. giving abundant nourishment to many kinds of anadramous and fresh-water fish, which are seined by the ton and carried daily to the Newbern and Wilmington markets, as well as to a great variety of luscicus oysters, crabs ard terrapins. There is no such nursery for fish of all sorts and proclivities as New River and White Oak River adjacent. I have seen the drag nets capture at one haul both large and small-mouth black bass, rockfish, blue and yellow catfish, mud cats, yellow perch, white perch. chinquapins, red horse, mullets, sunfish or robins, white and hickory shad, branch herrirg, red drum, shots, weak fish, pickerel and garfish; and once, at the Newbern annual fair, which occurs every February, there were eighty varieties of sea and inlard fish displayed, all fresh caught from neighboring waters, besides nineteen varieties of oysters. A happy combination of sound, river, estuary, ocean and inflowing creeks, and a meeting of tidal fluvial currents has made the waters of Eastern North Carolina the most prolific nursery and pasture ground for edible fish of all places on the coast. Early in February white shad began running, and with the melting of the ice and warm weather which ensued, the run waxed heavy Herring will follow the shad, and seining for both species will be active until the middle of May. Seines are operated in some localities by steam, and $\$ 10,000$ profit has been realized by a single fishery during the season. As many as 180,000 herring and 3,000 shad have been captured at a single haul. Some seines with the ropes attached make a circuit of a mile. An outfit for fifty men costs \$.2.,0nn.

Besides seines gill nets are used for catching shad, which, stretched on poles lengthwise of the river, sometimes extend for a mile or more. And all the way up the rivers are fishing stands made of poles or planks projecting from the banks, where negroes stand with long-handled dipnets, and scoop the fish as they ascend to spawn, sometimes lifting out as many as half a dozen at a time, worth 75 cents per pair. Occasionally rude windlasses are seen, fashioned of unpeeled logs and poles, and used for hauling drag nets, and there are also stake nets set across the mouths of tributary creeks. Every settler along the riverside makes full use of his riparian rights in this respect, and for a month past fishermen have been making big earnings, two crews of ten men each having divided $\$ 700$ in one instance as the net profits of twenty-four hours' fishing.

As to angling for sport, pure ard simple, it is an unknown art in these waters. In December a great many weak fish or sea trout are caught with hooks and handlines, and during extraordinary runs, such as occur periodically, hosts of amateurs, including ladies, join the ranks of piscatory professionals. This fishing is done in the ricinity of Beaufort and Morehead City, on the beacli. In the fall there is some lively trolling for bluefish, and in spring for Spanish mackerel, off the beach, but river angling is almost unpracticed. Occasionally a venerable negro will take his rickety old punt and steal away to a favorite bend in the stream, where there is a deep hole and a stake to tie to, and sit so quietly that his russet garb can hardly be distinguished from the dead grass of the marsh which lies alongside. But sportsmen are seldom seen on the rivers. Natives do not understand fly fishing and other scientific methods, and northern anglers have not yet found their way hither. When they do they will have a rich experience. All 
through April the bass fishing is superb, but I would not encourage angling in May. which is the spawning season.

New River is no marsh-lined, reed-bordered alligator creek like many streams on the southern seaboard, but a delectable broad water, with bold wooded shores, which are interrupted by occasional fresh-water creeks and umbrageous promontories, which are successively unfolded to the enraptured gaze as the excursionist proceeds on his voyage in steamboat or naphtha launch; and all along this beautiful estuary club houses, shooting boxes and villas have taken possession of advantageous sites. Conspicuous on the water front is the "Glencoe Stock Farm," operated by Thos. A. McIntyre, Esq., of the New York Produce Exchange, bearing some similitude to Mt. Vernon on the Potomac, with its pretty waterside pier, steam launch, pleasure yachts, cozy waiting house, flight of 100 steps surmounting the wooded heights, and carriage road winding by graded ascent through a natura] glen. Within the year, since the completion of the W. N. \& N. Railroad, of which Mr. McIntyre is president, traffic has grown to proportions which command the unremitting services of two large freight and passenger steamboats, with accommodating docks and warehouses at two points. One of these wharves is $6 \tilde{2} 2$ feet long. Government improvements are being pushed at various points. Game is quite as abundant as fish. Geese, ducks, brants and other wild fowl congregate along the margins of the sounds and at the mouths of estuaries. Deer and wild turkeys are in the timber. Partridges and quail are found in the old fields and plantitions. Bears are the pests of farmers by their nocturral visitation to hog pens. Coons and 'possums are abundant.

I am somewhat particular in detail, because I believe New River to be the coming winter and summer resort, by its supervening natural attractions, its equable but bracing climate, and the accessibility with which it can now be reached from all points. Hitherto it has been little frequented, but the development of many new industries, and the investment of large capital right there is bound to bring it into notice. There are good hotel accommodations at Jacksonville, the county seat of Onslow, and a thrifty village. If the visitor would wish to make headquarters at Newburn, it is within an hour and a half by rail.

Note.-This chapter was written in March, 1395.-Enitor. 


\section{CHAPTER XX.}

THE NEW DISPENSATION OF FISHES.

IN the middle of last April, when the incoming steamers from Europe reported icebergs adrift off the New Foundland Banks, sagacious minds predicted marine phenomena of marked character. The presence of these bergs two months in advance of their. usual appearance indicated warm weather in the polar zone, as well as the projection of an Arctic current into a portion of the South Atlantic hitherto dominated by the Gulf Stream. Subsequent investigations by intelligent sailing masters discovered that the Gulf Stream had been so encroached upon by a cold current as to force it 600 miles out of its course. As this influx of ice water showed a temperature of $32^{\circ}$, it became easy to account for the long and backward spring, the cold, foggy and rainy weather which beset our eastern coast line until as recently as the 1st of June. Its effect was seriously felt as far south as the Capes of Delaware. Furthermore, it was a logical inference that such great changes must exert an important effect upon the marine fauna, introducing new species from the northern seas, and perhaps temporarily driving off some species long recognized as local and indigenous to the waters whose temperature had been thus suddenly chilled. Another natural consequence would be to introduce vast supplies of fish food in new variety, to replenish a very sensible depletion long since discovered to exist upon the old feeding grounds of our best known commercial fishes, and thereby to invite their return to those resorts long frequented by the fishing fleets. Present results are justifying these conclusions.

For a dozen years past there has been a marked dearth of cod, mackerel. herring and other varieties of fish, with poor fares and indifferent catches all along the shore and banks. Causes visible and unknown combined to produce this depletion. Fishermen had almost begun to despair of success, and were preparing to seek other employments, when, by one of those opportune operations of nature which can seldom be anticipated, fortune suddenly rolled in on the flood tide of the Arctic current; and now they are finding abundance instead of dearth. All vessels are coming in with full fares, bringing reports of fish crowding the ledges and marine meadows of their old haunts, and carrying joy all along the coast where livelihoods are gained by the hook and trawl. Bluefish, weakfish, mackerel, cod, striped bass, halibut, and nearly all varieties are being caught a month earlier than usual, and instead of striking at successive points along the coast as has been their habit, and working their way from southern waters to points northward, they seem to have invaded the whole coast simultaneously from Nova Scotia to the Chesapeake.

No doubt a change of water and a change of temperature will work out other results equally beneficial and less expected. As has been intimated, species whose habitat has been restricted to other localities, are likely to be taken on new grounds hitherto unfrequented by them. Their distribution will be widely extended. Possibly the lobster, now so nearly exterminated, will reappear in increased size and numbers. Even the gigantic marine fauna-the norwhal, the whale, the sea lion and the walrus-may return to the haunts they frequented three hundred years ago, and their presence as far south as Long Island Sound 
become no longer a novelty. Oysters, clams and other shellfish may be stimulated by an infusion of new diet and new materials for vigorous growth to increased reproduction. There is no need to the speculative benefits which are likely to result from the temporary displacement of the Gulf Stream by the polar current. Whether it will soon resume its old channel, or whether the change is an initial to mark a new climatic epoch like that which converted the Greenland of the early Norsemen into an icy and sterile tract, is a problem which may well be contemplated with more than ordinary interest.

Note.-Written in 1883.

THE EXPERT ANGLER.

Assuredly "bookish wisdom" and finical acquirements do not make the fisherman. Militia soldiers on dress parade may present as effective an appearance as veteran regulars, but something besides toggery and efficiency in the manual of arms is required to make a good fighter. An angler with superfine tackle and rig may astonish the natives by his professional make-up, but unless he "understands the habits of the fish and the character" of the water he fishes, he will make but a poor fist of his angling. His ingenious manipulation of the rod will scare more fish than it will attract, and all his frequent ehanging of flies and monkeying with his patent shop contrivances will only lessen his chances of filling his creel. If a gunner be restless and uneasy in the "blind," you may be sure the geese will veer and fly high.

There is a closer analogy between hunting and fishing than many people affect to believe. I am always surprised when I do not perceive the same caution exercised in approaching the denizens of the rivers as the fauna of the forests. The ostrich with his head in the sand is not more foolish than the man who fancies the fish cannot see him because he cannot see them. A practiced eye will detect a motionless fish or a glancing flash in the stream where one who is unaccustomed is unable to discover it after it is plainly pointed out. One should approach an eligible part of the stream with unvarying discretion, even though it appears to be barren. Hundreds of soi disant anglers ruin their chances at the outset by the clumsy manner in which they approach the timid creatures which they propose to entice and lay hands on. If market gunners behaved in like manner, utterly ignoring the first principles of drawing on game, our city epicures would get no canvasback ducks. A great deal more is included in a "knowledge of habits" than consists in the mere superficial understanding of what fish eat, how they live and what will attract them best or bring them safe to creel. If it be true of the forest, it is equally true of the brooks, that too much beating about the bush defeats its ends. The silent hunter or angler, and quiet methods, secure the goodlier results. If opinionated tyros only knew by what great painstaking baskets are sometimes filled, they would discover that they have something yet to learn in order to attain the acme of high art. A farmer's boy will crawl on his belly for twenty yards in order to get at a big trout under the bank, and ten to one he will yank him out. Herein he develops several requisite qualities of a true angler. He is familiar with fish habits, and he exercises caution and patiencewithout which success would be impossible. It is by the application of these that the tow string is able to discount the silk line and reel. Books do not impart the practical information which that lad possesses. I once met a party on the Nepigon, late in the season, who had been fishing all the choice places along shore where fish abound earlier, and had taken none. I took them in a canoe to a riff 
in midstream, where a small island divided the current, and they caught a boat load. You see, a man may be a prize winner at a fly-casting tournament and yet have no "luck" on the streams.

It is not my purpose in these desultory notes to discuss low-grade and highgrade angling. Of course a masterly cast with the fly will pick up a fish which a gob and wattles can't reach. We all understand that, and we have long been familiar with the logic which, from the days of Saladin, prefers dexterity to brute force, commending that which soars above the thing which grovels. I am simply trying to show where those who attempt to practice high-grade angling are deficient, and that many who talk by the book are but bunglers in the manual art. It is not every man who can talk horse that is able to keep his saddle or handle the reins. Some pretenders may have the written code at their tongue's end, whereby they mystify the credulous; but they never can deceive a veteran. An expert can read them off-hand and detect their short-comings the instant they step toward the animal to take hold of the rein or put a foot in the stirrup. It is so with the man who handles rod or paddle. It is not necessary to take him to the river side to size him up. An apparently insignificant movement will give him away. It is the same with the man who takes hold of a gun or ax, billiard cue, foil or Indian club; who steps into a carriage or a boat, or enters a drawing room. Ignorance cannot be disguised. It is the companion of awkwardness, and the two go always hand in hand.

One chief reason why most trout anglers fail is because they don't keep their eyes on their work. I do not believe that a short-sighted individual can be perfectly successful. He must miss a great many fish that rise. An angler should never take his eye off the water. It should follow with constant vigilance the vagaries of his flies. He should retrieve his line as seldom as possible; being sure always to strike the instant he thinks he detects a gleam. The motion of a trout is often quicker than the glance of the human eye, and unless the angler is on the alert the trout will have seen and investigated the lure before a contemptuous flap of the tail has made the angler aware that he has come and gone. Often an upward lift of the rod tip will hook a fish whose presence was not suspected at all, the barb fastening to its tail, side or gill. Such incidents as these have given rise to the notion that trout knocked the flies into their mouths with their tails.

One object of wading a stream is to avoid observation. Proper wading is the most deliberate operation imaginable. A good wader will scarcely roil the water in a mill tail. He will often pick up a score of fish without moving more than a couple of rods. The fish will so little heed him that they play about his legs. I have often waded through a school collected in a long reach of fairly deep water, and then getting out on the bank and going back to the beginning, fished the same pool a second and third time with tolerable success. Wading also enables the angler to cover water that he could not otherwise reach, and it permits him to fish with a short line. It is a great mistake to fish with a line that is not under complete control. There is a great difference between strean fishing and pond fishing. I seldom attempt a long cast. The more line one lays on a still surface the shyer the fish become. A long line is like a long-range sharpshooter's telescope rifle-intended to bring game where less effective weapons fail. A thirtyyard or even twenty-yard line, laid evenly out on the wings of a masterly cast, is an exquisite performance, but the accomplishment is seldom of practical use in angling.

I remember once an amusing incident at Ridgewood, Long Island, where a 


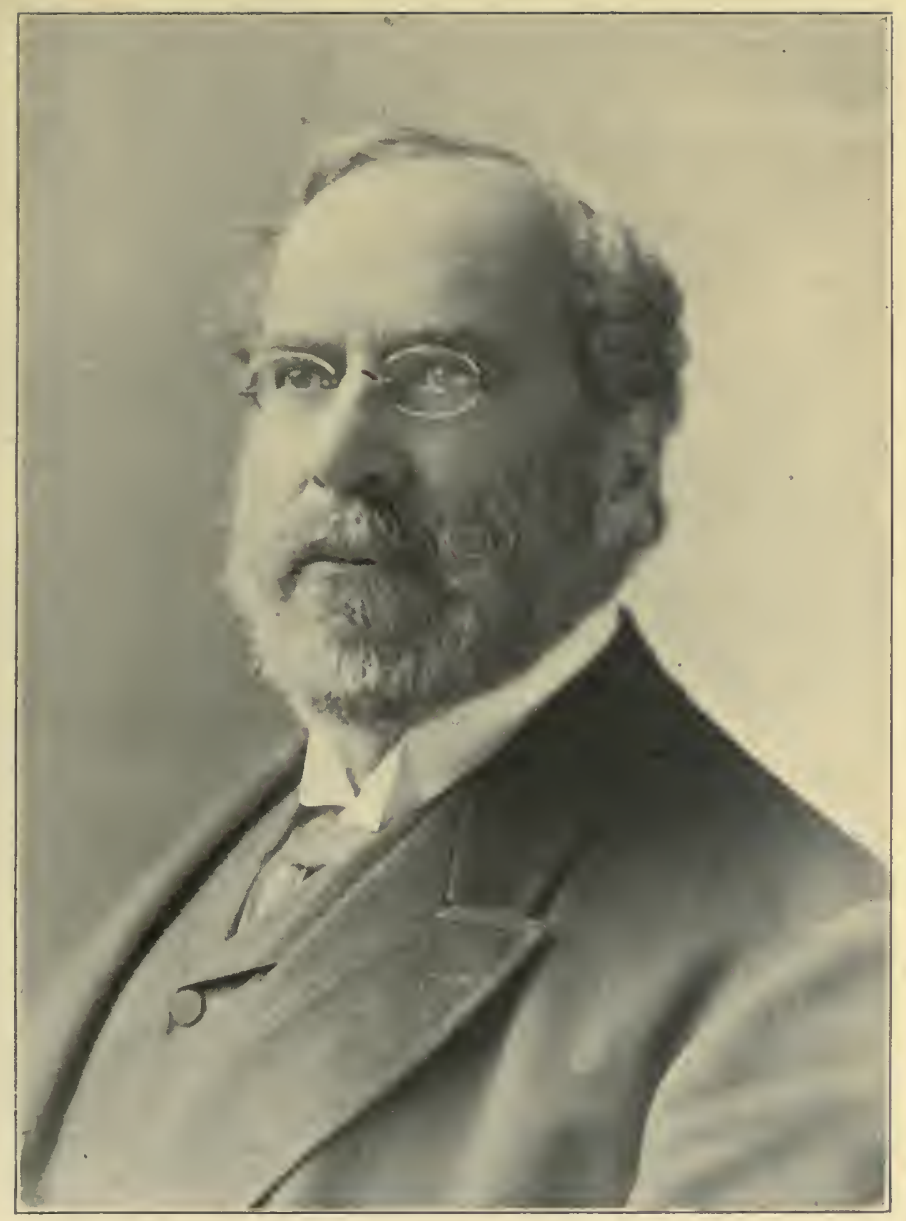

HON. ROBERT B. ROOSEVELT, ANGLER AND AUTHOR. 

visitor was permitted to fish an artificial pond of liver-fed trout, which were in the habit of rushing en masse after anything thrown in, until they fairly made the water boil. Of course they were not afraid of man at feeding time, though they were a little shy on off hours, and of course our ambitious angler took a fine trout at the very first cast, standing in full view upon the bank. If he had had a "trot" line he could have taken two dozen on as many hooks. After playing him well to creel, enjoying the suspense of a well-hooked captive for several minutes, he cast again, expecting a repetition of the same old rush, but nary rush did he perceive. A fingerling or two broke gingerly at his tail fly, but the most persistent persuasion failed to fasten another trout.

Haec fabula docet that dead failures are possible in the best stocked waters, and that the shoemaker is worthy of his last-or words to that effect.

\section{HON. ROBERT B. ROOSEIELT IN ANGLING LITERATURE.}

I am convinced that the Hon. Robert B. Roosevelt has not had full credit for the very important part he has occupied in the American anglers' guild, especially during the civil war period, when the young men of the land, and old ones, too, were too much engaged on the battlefields to spare time for sport, except it were to eke out an occasional deficient ration for the camps by whatever game and fish could be caught during temporary cessation of hostilities. Mr. Roosevelt was the living intermediate who bridged the interval between Frank Forester and the writer, whose "Fishing Tourist" (1873) and "Sportsman's Gazette" (1877) brought the angling literature of America to its climax and was so attested by Gill and Jordan. How comprehensive and aptly this history has been presented in bibliography may be ascertained by reference to the columns of the London Field ( 3 papers), for June and July, 1887, under the title above given. The compiler, in his review of the period indicated, allows that "nothing like a comprehensive manual of angling was published until 1864, when Thad Norris' 'American Angler's Book' and Robert B. Roosevelt's 'Game Fish of the North' both came out." That was during the year of the first lease of a Canadian salmon river, the Nepissiguit. Roosevelt's book made especial reference to that famous stream in its chapter on salmon fishing, itself a new revelation to the fraternity of fishermen. How to fish for salmon and the implements to be used, and a description of the sport, had never been presented before. The volume was a godsend to anglers, for it included the technology of angling, fly-fishing, tackle-making, entomology, fish culture, camping out, etc. It described new devices, new methods, and new fields of sport which had come into the purview during the sixteen years that had intervened since the enterprising J. J. Brown had prepared his "American Anglers" Guide" (1849). Moreover, it introduced new species of fishes not previously regarded for sport and identified others which had been in doubt. The whole subject was in chaos at that time, scientifically considered. Experts had not even quite determined whether a brook trout and a samlet (parr) were the same, or that brook trout were not in fact immature salmon. The scientific world has moved since then mainly by the contributions of men here present.

In 1865 , the year following his first production, Mr. Roosevelt put out a supplementary book entitled "Superior Fishing," relating chiefly to the fishes of the Great Lakes, and touching the lately mooted subject of fish protection. These two books, as well as my "Fishing Tourist" and Prime's "I Go a-Fishing" (1873), were all published by the Harper Brothers.

Not only must Mr. Roosevelt be recognized as a well informed author of undoubted accuracy and reliability, but he was foremost with Agassiz, Baird, Garlock, Ainsworth, Samuels, Prime and Mather. 


\title{
CHAPTER XXI.
}

\author{
BOBBING FOR EELS.
}

SpEAking of eels, Mr. Editor, I don't know of anything that will make a worse mess in a boat full of hamper and loose lines than a big, active eel, fresh drawn from the mud. It is not so much that he twists everything into an inextricable snarl, but he befouls everything he touches with a viscous slime which nothing but drying in the hot sun will effectually remove. Of course, in trying to clear the tangle, the slime gets on one's hands, and when they are once besmeared you are comparatively helplessFrenchmen would say hors du combat; in fact, a foreign language can alone express the predicament.

Perhaps you know how it is yourself? Eel slime! Slippery is no name for it. It is slicker than goose grease and as sticky as fly-paper. Did you ever try to turn a door-knob with your hands soaped? It didn't turn, did it? But you could let go all the same? Well, ecl slime sticks while it slips. It is fast and loose at the same time. It holds on while it lets go. Its ambiguity is as queer as the Irishman's frog which stands up when he sits down. You can no more unsnarl a coiled line with an eel in it than you can eat soup with a fork. If you are new to eels, or ecls are new to you, you are likely to persist in the effort until you are as hopelessly involved as a fly in a web. The eel will thread loops and bights faster than you can open them out. He will thrust his head through one ganglion and his tail through another, and then tie himsalf into a running bowline, and reeve himself through the turn of the knot, and come out both ways at once. And your hands are getting slippier and stickier all the time. You cannot hold on to the eel, and the line won't let go of your fingers. Your only recourse is to cut it off as close to the snarl as you can and throw the whole mess overboard together.

But one can seldom get off so easily. Voila! When the line has taken several turns around the painter, and over and under the cleats, and through the handle of the water-jug, and over both oars, the only alteratives are, either to knock the boat to pieces, or cut everything loose with your jack-knife. Of course the knife is in your pocket, for, being a novice, you haven't thought to leave it handy on the thwart, and the quandary is how to get it out and open without daubing your clothes and the knife, and splitting your thumb nail. In any event there can be but one solution of the gordian knot, and one series of results, and these are a much-soiled suit, a spoiled holiday, an irrepressible eel, and a score of two-feet lengths of cut line useless for shoestrings and not strong enough for reef points.

As a matter of fact, no one but a tyro will angle for eels unless he is properly equipped and prepared. Fishing for eels, Secundem artem, as an expert fisher, is one thing to catch one by chance, while fishing for other fish, is quite another matter. If ever an old fisherman becomes involved with an eel, the incident takes him quite unawares. No greater 
misfortune can befall an angler in a boat; but he is always equal to the emergency. When an eel-sharp discovers what he has on his line, he summons to his aid his cutest expedients. He first clears all hamper from the bottom of his boat, and then lifting the eal dexterously over the gunwale, slips his foot on to his neck as he falls squirming to the boards, and deftly disengages the hook; or, if the hook be gorged, he cuts the line, or even amputates the head, care being taken to throw the body overboard forthwith, or else to place it where its prolonged contoritions can do no mischief. The most expeditious and approved method of dealing with such hard cases is practiced in the West Indies, where the moray, which is the most obstreperous of all eels, is hauled head-foremost into a smack's scupper, and then clubbed as soon as ever his head appears inboard. This moray is armed with wicked tèth, and his vicious attempts to bite make him a two-fold terror.

I used to know something about eels when I was a boy, and I fished for them con amore, especially those sweet salt-water eels, not of inord. inate size, but just large enough to be good when cut into three-inch sections, rolled in corn meal or bread-crumbs, and fried brown. Many an appetizing meal have I made off fried eels at Nettleton's on Morris Cove, and down at Five Mile Point, in New Haven harbor, and around at Double Beach, and at Malachi King's at Branford, in the old days. The head of the harbor is shoal, and when the tide is out it leaves broad mud flats which harbor shellfish in variety and profusion.

Between the sand-beach and the flats was a ribbon of mussel-beds and sedge, with an upright face eighteen inches high toward the water. When the tide made, and the young flood had filled the head of the harbor so that the depth of the water. was even with the top of the sedge, and all the barnacles and kelp which overlaid it began to seethe and hiss with the gently-lapping waves of the advancing tide, I used to moor a flat-bottomed skiff so that it would tail in toward the shore, and near enough to permit me to toss a line in under the breast of the musselbed; there sitting in the stern I caught eels galore.

The best time to fish was in mid-summer at the full of the moon, but I could discount all legitimate methods of setting a lantern in the sternsheets on a dark night, with a southerly wind blowing up the harbor. Then the eels would come up to the surface in schools and play about the boat near enough to be touched with the hand. I could have scooped a score at a time with a dip-net, but, scorning mean advantages, took them fairly. I used a stout ten-foot handline with a bob of earth-worms, and I had only to haul them in as fast as they caught on, lift them over the gunwale, and slat them into a bushel basket placed conveniently at hand. Assuredly, it was great sport. Seldom did one gorge the bait, or tangle his teeth, so that the process was simple. Naturally I became quite an adept in threading worms with broom-straws and bunching them into attractive bobs of red-ripe lusciousness which was hard for eels to resist.

I never knew of but one lure to beat earth-worms. The same reminds me of the eel-pots I used to set off shore, marking their location with buoys so that I could visit them at flood tide and boat their wriggling contents. These pots were wicker cylinders thirty inches long by a foot in diameter, with a funnel in one end, and were baited with what would most attract. Offal was perhaps better than anything else.

Jote.-This chapter was written by Mr. Hallock in 1886.-EDitor. 


\title{
CHAPTER XXII.
}

\author{
WHY FISH DON'T ALWAYS BITE.
}

THE subjoined extract is made from an anonymous letter printed in 1885. It is a most instructive contribution, as the facts gleaned have been obtained from continuous observation of the habits of fish in feeding. The fish in question are black bass confined in a large glass tank or aquarium nine feet long by two feet wide, and two and a half feet in depth. The writer describes their manners and methods when served with live food, such as shiners or minnows. He says:

"Such a meal is always a most interesting scene. If the fish are very hungry they will show it by an increased restlessness. They are then more alert and active, swimming back and forth, sometimes chasing and attacking each other. These encounters may be mere fish play, yet there seems to be too much temper in them-too much promptness to strike back for that.

"But when the bucket of live shiners is served to them they at once come to order. They await no grace, only the lesser fish are supposed to await upon the greater, which they do with just as much filial obedience as the big fish can enforce. It is but a display of human selfishness on a more unreserved scale, where might or muscle makes the law. The large bass make the water boil as they dash on the huddling and terrified shiners that try in vain to elude them. Again, they will charge on the smaller bass to hold them back till their own wants be satisfied. And it takes a great deal to satisfy them, for their selfishness makes them gluttons, or else their honest capacity is amazing. They will gorge themselves and then lay off, often for several days. Frequently those as small as two pounds have been observed to take from ten to fifteen two to three-inch shiners at one meal. This makes it tolerably safe for the shiners for at least three days. Their favorite feeding time is early in the morning."

From the foregoing the reasons are made sufficiently obvious why fish bite freely at one time and not at another in the same water and the same locality, and why some anglers have "good luck" today and some have bad tomorrow. The fish gorge themselves and take a rest. It explains also why small fish only are taken at certain times when large fish are known to be abundant. It is because they have been made to wait until the big fish have fed. Their opportunity comes while the latter are lethargic and quiescent with surfeit. The duration of the intervals between good fishing and poor fishing is ascertained, for the bass are frequently off their feed for several days. Meanwhile the shiners have opportunity to multiply and develop; at least they are improved by accessions from other localities, for it is notorious that they do not seem to diminish from year to year as a rule. There is another reason which may be added to explain good fishing one day and poor fishing the next, to wit: the nomadic habits of the minnows, which shift their locality from time to time, the big fish, of course, following them. Good judgment would therefore instigate an observant angler to try a different stand in another part of the fishing ground, if he gets no bites today where he had success the day before.

We find also from our friend's observation what experience had already taught us, that the morning is the proper time for fishing. Indeed, of late years 
I have wasted no hours between 11 o'clock a. m. and 4 or 5 o'clock p. $m$. There is usually a good spurt in the evening, when fish bite freely.

\section{WINTER-KILLED FISHES.}

People are often puzzled to account for the mortality among fishes, which are frequently found dead in large numbers, in the ocean and inland waters alike, and at different seasons of the year, sometimes in midsummer and sometimes in the spring after the ice breaks up. There should be no mystery in this. Why should not fishes be subject, like animals, to epidemics from diseases and widespread death from natural causes?

If we turn to the elements of natural history we read that fishes are coldblooded vertebrates which live exclusively in water, and respire by means of gills instead of lungs; and that in process of breathing, the oxygen needed is secured from the air which is mingled with the water. Fishes, no less than animals, are kept alive by air, and without it they die. The phenomenon referred to by your correspondent "J. G. R." in a recent issue of The Angler, where great quantities of pickerel were found dead in Lake Umbagog, Maine, after the ice went out in the spring, is one of the causes of fish mortality most easily explained. The fish died from want of air.

If we place a given, number of animals in a circumscribed apartment where no fresh air is admitted, they will exhaust the oxygen in time, and then die. In like manner, if a body of water is hermetically sealed by ice, the oxygen it contains will be exhausted in time, and the fish will die. But ice is porous, and unless it becomes solidified by intense severity of cold, air passes through it into the water below. Also, in temperate climates, there are usually throughout the winter occasional periods of thawing, by which process air is absorbed; the ice along shore is also melted, and air-holes are found in the body of the ice, to which the fish instinctively resort, as animals would do to crevices or open windows in the closed apartment, and are thereby revitalized. Under such conditions no mortality occurs.

Sometimes there is an unseasonable rainfall in the winter season which overflows the ice of ponds or lakes; or the feeders of those lakes may be swollen by a flood and overflow the ice; and it is thus not uncommon for fish to find their way to the overflowed surface through the air-holes, or the open water along shore, seeking for air. If a hard freeze follows, these fish, becoming benumbed and unable to find their way back, are frozen in and remain imbedded until the ice finally melts in the spring and leaves their released carcasses floating on the surface of the water.

Again, when the winter is ushered in by extremely cold weather, and the water freezes rapidly, fish will congregate at open spaces for air, keeping near the surface, and before they are aware of it the ice forms around them and incloses them. I have seen large blocks of clear ice cut from the surface of deep ponds for domestic uses, containing many catfish and bull-heads, which are bottom fish with hibernating habits; but the winter unexpectedly overtook them before they were ready to assume their torpid state and bury themselves in the mud. Ordinarily they would have avoided such a catastrophe.

Some fish are more subject than others to mortality from this cause. Pickerel, for instance, as referred to by your correspondent, prefer to keep on the shoals near shore among the aquatic plants and weeds. In winters of alternate thawing and freezing, they would be even better off there than in the deeper waters, be- 
cause the ice would occasionally become broken along shore, and the plants themselves supply oxygen; but calamities come when most guarded against, and the pickerel of Umbagog may have been inclosed by the ice freezing rapidly to the bottom, or even imbedded by a severe and rapid freeze at the beginning of winter. The chubs, suckers and trout escaped because they kept in the deeper water, which had not been exhausted of its air, or gathered around the mouth of inflowing streams, where small spaces are usually kept open all winter by the current. The pickerel delayed seeking the deeper waters until it was too late, and they were imprisoned.

The success which almost invariably attends winter fishing through the ice is due to the fish being attracted to the holes in quest of air. Some species of fish consume far less oxygen than others, and will therefore survive conditions which would be fatal to those. This will also partly account for the immunity of the chubs and suckers, while the pickerel died.

Mortality of fishes in the ocean is often caused by sudden changes of temperature occasioned by the shifting of marine currents, just as sheep and cattle in the Southwest are killed by a dry norther.

Sometimes fish are poisoned by the sudden outburst of subterranean mineral springs or volcanic upheaval. Indeed, may they not, like terrestrial organisms, be subject to epidemics and plagues, fever germs and the numerous fatalities which result from sudden exposure to changes of temperature, or even of unfamiliar agencies which pervade the air, the water and the submerged land. There are analogies throughout all nature, which if compared together, account for much that is inexplicable. It is chiefly those things not seen which are mysterious.

\section{"HOLDING HARD AND KILLING QUICK."}

In an-issue of The Angler the editor recalls some angling reminiscences at Yankee Dam, on the Schuylkill, where he had some sharp work with a black bass. He speaks of holding hard and killing his fish quickly, and invites criticism of the method and performance; therefore, I am free to say that, under the conditions illustrated, I do not see what else he could well do. Indeed, it was masterly work.

Inexperienced anglers should learn and remember that in the rough water under all dams and natural waterfalls there is always a backset and undertow; which operates greatly to the angler's advantage. It is to his interest to keep the fish within the swirling water, and not let him run out into the uninterrupted, swift current below. In the latter case, unless he gives line freely, he must break tackle or lose fish; for the direct result of holding hard then is to bring the fish to the surface of the water, where the great force of the current would of itself tear the hook out, unless it was so securely fixed, and the fish so heavy, as to cause some part of the tackle to give way.

While holding a fish hard in the swirl the great knack and point is to so counteract the leaps which he will be sure to make that he will not be able to throw himself off the hook. The strain of the tense arch of the rod is something immense. Instinct seems to teach the fish to take advantage thereof by leaping clear of the water, so that, by momentarily relieving the strain, he may free himself of the hook. In this little game he will generally succeed, if insecurely fastened, unless the angler instantly responds by lowering the end of his rod to a plane parallel with the level of the water. He must repeat this with each upward leap of the fish, often two or three successive times in a minute. This is what gives excitement to the sport far beyond that experienced in sluggish or 
still water. It is a battle of muscle as well as of tact and strategem; and when you finally bring your fish captive to your hand, you not only experience a natural thrill of joy at your success, but you entertain such a respect for your fish as will magnify your own self-importance many fold. In fishing short salmon pools in heavy water there is no other resource but to "hold hard and kill quick." The salmon must be worked toward the head of the pool (they almost invariably take the fly at the foot), and brought to gaff at the earliest possible moment; for if they are once allowed to run out of the pool into the dashing raceway below, one might as well try to hold a locomotive with a clothes-line.

In following this advice to "hold hard," there is always.danger that the pupil will fail to temper his strength by that delicacy of manipulation which can only be acquired by frequest tests through long experience. A familiar illustration of this is the tendency to jerk a fish bodily out of the water as soon as he is on the hook. What is meant to be sport then becomes nothing more than a combined mental and physical spasm. Old anglers learn to weigh mechanical forces with a keen perceptive sense, which enables them to determine when their rods are overtaxed, just as they can tell, by an intimation of the spine, that they are lifting too much.

After all, there is something more in the science of angling than the agnostics seem willing to admit. It can be measured only by the multiplicity of conditions under which it is pursued, and he who attempts to "hold hard" when he ought to touch lightly will find himself in a worse predicament than the Frenchman with his head out of a car window, who cried, when he had barely escaped being hit by a bridge: "What for you tell me to look out, when I should look in?"

\section{WHAT IS FLY FISHING?}

Don't you sometimes feel like leaving the beaten path by the river when your correspondents sail up to you with their cork helmets a-cockbill and begin to talk about the advantages of shotting your fly, of lettirig it sink a foot or so beneath the surface, of using a stiff rod for better effect in casting, and all such sort of loose talk? I say, is there any sense in it?

I don't object at all to the methods, but I write to ask why their use and practice is designated "fly-fishing?" That is what I am awake to know!

What is a fly? Is it an insect which dives, which lives under the water, which goes to the bottom water-logged, or double-shotted like a corpse over the side, at sea? Not at all! It is a creature of the upper air and surface-ephemeral, lambent, light as thistle-down, erratic as a feather, now touching the water, anon darting into midair, here an instant and gone the next, restless as a hummingbird, never still. Do you not perceive, then, that when you handicap an artificial fly with a weight, however trifling or minute, you immediately take it out of its class, because it is a fly no more? It has not even the capabilities and attributes of a beetle, or grasshopper, or any other clumsy insect which happens to have wings. It has no buoyancy or vitality. It cannot rise, or even maintain itself on the surface unless the current be swift. It is inanimate and dead. Fly-fishing indeed! It isn't fly at all. True fly-fishing is an art which brooks no compromise. It can never be engrafted or modified. Cross it with other methods of angling and you have a sterile hybrid.

In the early days the aborigines used a bunch of feathers, hair, or deer skin, arranged with rude regard to form and combination of colors, which they called a "bob." They used it with a rod and short line, after the fashion which the 
English call dabbing, or skittered it over the surface of the water; and with it they caught many goodly bass, trout and pickerel. This primitive lure was really a home-made hackle, and the way in which it was used was much nearer akin to true fly-fishing than any sub-aqueous method employed since. Improvements on the bob began when contrivances were deftly fashioned into close resemblances of natural objects, the outcome of which has developed into the marvelous artificial fly of the present day. The moment metal attachments were devised and applied for the purpose of intensifying the lure, or to imitate aquatic objects, the evolution of the spoon began; and the greater the progress we make in perfecting the spoon, the further away we depart from its origin and germ, the primitive bob. There are composite plants which yield diametrically opposite products. Just so the bob is the parent of both fly and spoon; but we can never interchange one for the other in the correct practice of arts so far asunder as trolling and fly-fishing. Engineers might as well try to use a diving bell for a floating battery. The ostrich, with his rudimentary wings might vie with the condor of the Andes in flight.

I am opposed, Mr. Angler, to combination implements and makeshifts of all sorts. A mechanical jack-at-all-trades simply ruins the brotherhood and demoralizes the craft. Give me fly-fishing in its purity-or give me worms. 


\title{
CHAPTER XXIII.
}

\author{
"FYSSHE AXI FYSSHEYNGE."
}

[Before the Minnesota Academy of Sciences, 1881.]

THus as written, wrote Dame Juliana Berners four centuries ago. We do not spell it that way nowadays, but the subject stands the same, unchangeable, fixed, eternal. The same interest invests it now as then; the same enthusiasm is kindled in old and young alike. In infancy it is the initial out-of-door pastime. When old age has outlived its usefulness, it still can fish; and even after the mortal coil is shuffled off there gleams a constellation in the heavens, beyond the dead line, to illuminate the angler's path to glory! Thus from the beginning of antiquity, when "the waters cavered the face of the earth," until the ultimate end of time, the art and the subject are alike illustrated and ennobled. The pride of his calling dignifies the fisherman, while topics much less scaly fail to win equal plaudits for the pen.

From the days of Oppian, who was chief poet of the second century, until the most recent rhapsody of the modern author, the art of angling has been chanted in song and expatiated upon in prose. Prof. J. J. Manley, of London, tells us that there are no less than 800 books on angling and cognate subjects. The literature of angling embraces the names of some of the most distinguished men of the centuries. Angling is a standard gossip in the tackle shops and around the camp fire. It is a subject on which any self-constituted censor may assume to talk intelligently. So kaleidoscopic are its phases that none may venture to gainsay the most random statements; so tuneful are its changes that it never grows trite. Its associations are hallowed by its "ancient and fish-like smell," like the old wines of Tokay and Johannisberg by the must of the cellars. Nevertheless it is an uncertain field of research, and I approach it with some such wariness as I would an old root under a river bank. stuck full of fouled hooks, and bristling with broken snoods and bits of line, knowing full well, from the circumstantial evidences, that there is a big fish under there difficult to handle.

Ah! here we have an immediate suggestion of the charm of angling. A big fish difficult to handle! Herein consist the challenge and incentive to any essay of personal skill. How the wary old fisherman will rub his hands and chuckle, as he cunningly selects and adjusts his most captivating lines, to victimize that educated fish who has outwitted all before him! How carefully he lays out his lines and establishes his approaches! And if he can only once get fairly hung of that fish, what a crown of glory will he begin to burnish up for himself?

But I do not intend a tilt in the open field of angling. I will not even attempt to epitomize a subject of such vast amplitude and illimitable ramifications. I am a free lance, merely touching a few salient points with the lambent flight of the bee.

Imprimis, I find that there is a certain kind of ozone in the spring atmosphere which makes an angler wish to go a-fishing. He takes to water as naturally as a duck. Thenceforth what enchantment invests the dark and shadowy river with its varying mood and cadences; the rattling ripple and the murmuring eddy; the pale buds of springtime and the umbrageous fronds of June; the catcall of the jay and 
the rasping trill of the kingfisher; the cdor of the ferns and the sweet breath of the opening flowers!

No wonder that the ardent angler takes the spring fever and begins to lift down his rods from the rack and overhaul his tackle. Even the small boy catches the infection and sighs for the waterside as he sits on his workbench and whispers:

"Father! they say-the trout-bite-good-now!"

"Bite, do they? Well, well; you stick to your work and they won't bite you."

What a Babcock extinguisher to the youthful fire! "Truth crushed to earth shall rise again;" but what of ambition thus mercilessly nipped in the bud? Where is Izaak? Shades of the departed!

There are those who affect to despise anglers. Perhaps they associate them with worms? Well, none of us should be too fastidious. One common destiny waits on us, and all will have to succumb to it sooner or later. We are liable, at any time, to furnish ground bait for bottom fish.

It is not for me to champion the Fraternity of Fishermen. They are abundantly able to speak for themselves. Even the fisherwomen are lusty in their self-assertion. It is hard to circumvent the eloquence of Billingsgate.

Daniel O'Connell and Richard Brinsley Sheridan both tried to talk down the fish wives. The great counsellor even went so far as to call one of them an "old hypothenuse!" but she berated him into ignominious flight!

(That was the last of the O'Connells.)

Heroically she defended the well-earned reputation of the craft, intensifying with glowing visage the reflected luster of the emblematic twelfth sign of the zodiac- "In hoc signo vinces."

Numerically, the angling fraternity is a power. In the city of London alone it is said there are nearly 100 clubs, with a membership of 3,000 , to say nothing of as many more regular anglers who do not belong to clubs.

In America are at least 100 organized angling clubs, with an average membership of over thirty persons. That this constituency is recognized as a power in the United States is demonstrated by the deference shown to sportsmen by hotel proprietors and transportation lines all over the country. Special excursion tickets are issued every season by many railroad companies, and some of them furnish excursion cars expressly fitted up for sportsmen, with sleeping bunks, kitchen apparatus, rod racks, etc. One line defers so particularly to this class of patronage that it has dubbed itself "The Fishing Line." For several years many railroad companies have catered especially to the anglers and sportsmen in general-their roads reaching many of the finest fishing localities on the globe. In Worcester, Mass, there is an excursion car company which leases cars to sportsmen. fitted up with every appliance suited to their requirements. Parties pay so much per day and travel wherever they wish, ad libitum.

Many of the most enthusiastic anglers are the railroad officials themselves. A fellow feeling, therefore, makes them wondrous kind. Let us be grateful, then, for the cordial sympathy thus begotten, and hasten to avail ourselves of the facilities which they provide. Now is the accepted time:

"Oh, while fishing last, enjoy it; Let us to the streams repair;

Snatch some hours from toil and study, Nature's blessed gifts to share.

$Y e$, who stand behind the counter, Or grown pallid at the loom,

Leave the measure and the shuttle, To the rippling stream come, come!
"He who clothed their banks with verdure, Dotted them with various flowers,

Meant that ye, tho' doomed to labor, Should enjoy some cheering hours;

Wipe your reeking brows, come with us, With your basket and your rod,

And with happy hearts look up, from Nature unto Nature's God." 
It is said "There are as good fish in the sea as ever came out of it." We know that many families of fishes have become totally extinct since the initial epoch of creation; but of those now in existence the total number of admitted species of fishes inhabiting the waters of the United States is something over 1,400, the number of genera about 200 , of families thirty-two.

Science divides the different races or groups of the world's fauna into classes, orders, sub-orders, families, genera and type-species. Apparent species of fish fauna are so numerous as to receive no attention from ichthyologists, unless they are verified by typical examples.

Of the thirty-two families referred to, most are fit for food, though a very large proportion have hitherto been rejected from the table.

Within two years, however, a club has been formed, with headquarters at New York, and a large outside membership, for the express object of utilizing as food what has hitherto been considered noxious or inedible. Qualified candidates must have no gorge or compunction of stomach, and at stated dinners the initiated ichthyophagi get away with an incredible lot of skates, shark fins, toadfish, lampreys, blowfish, sea cucumbers, echini, horsefish, sea spiders and the like.

A correct taste, however, long ago evolved and established four of the thirrytwo families as the choicest for food. These are the Salmonide, which include the trout, salmon, grayling, whitefish, charrs and smelts, represented by about forty varieties; the Centrarchidæ, which include the bass, sunfish and perches, in variety about sixty; the Esoscidx. which includes the pikes, pickerels and muscalonge, and the Cyprinidre, a very numerous tribe of dace, carp, chubs, etc.

These four families represent both of the great diversions of Acanthopterigii, or spiny-finned fishes, and the Malacopterigii, or soft-rayed fisies; and it is a gratifying coincidence, that these fine edible fish are the ones which afford the keenest sport to anglers. They are not only the most active, the most symmetrical and the most beautiful in colors, but they are universally distributed among the bright golden spots of earth. Their habitat is where the wood nymphs dwell, where the birds carol, the gaudy butterfies flit and the bees drone; where crystal fountains gush, and the green moss grows vivid in the spray; where every combination of romantic rockwork. waving foliage and tracery of ferns and trailing vinesof gentlest nature, animate and inanimate-combine to reproduce an Eden.

Wherever the leaping trout and sturdy bass are found there are no snakes. In the deep seclusion of these Edenal retreats no noxious serpent lurks. In this paradise without a devil, the harassed and toil-worn voyager seeks rest and quiet retirement, and the poet draws his inspiration:

\section{"Sweet Nature around me; the world's troubles far; Believe me, we fishers philosophers are."}

While all the four great families referred to are widely distributed throughout the temperate zone, the Cyprinoids are found chiefly in sub-tropic belts, and actually thrive in the hot and tepid rivers of Arizona and New Mexico. The goldfish, which is one variety of the family, is easily raised in warm, muddy water, and cannot stand too cold a temperature. He grows fat on a simple diet of bread crumbs, and with this homely fare is happy. The Salmonidae and many of the Centrachida, to which the basses belong, are not found in strictly sandy regions. Trout are finest in granite formations, and bass in limestone, though both are found in each. The Esoscidx, or pikes and pickerels, thrive in both rocky and sandy tracts, in clear running water and in turbid, sluggish ponds alike. They are particularly fond of swamps and marshy places. 
All of these fish will, at times, take the artificial fly, the trolling spoon, the live minnow or the still bait.

Besides these, there are the Siluridx, or catfish; the Clupidx, which include the herring and shad; the Hyodontidx, or moon-eyes-a large-eyed fish allied to the herrings, and the Scienidæ, or sheepshead, which afford good sport to the angler and are fairly edible food. The habitat of these is chiefly in Western waters. Several of them will take the fly, others a ground bait. The moon-eyes, or "golden eyes," as they are sometimes locally called, run in schools, and often give pretty fly-fishing in many of the tributaries of the Red River of the North, flowing through Northern Minnesota.

The great majority of people cannot distinguish one family of fish from another. Indeed, they camnot even distinguish the common varieties of the common domestic animals-the horse, cow, dog or pig; yet these varieties are very numerous. On the show bench at the great dog show in New York last April, for instance, there were sixty varieties of dogs.

We do not determine species by their colors, although colors are an indicationbut by their specific characteristics or anatomical structure.

Now, an expert ichthyologist ought to be able to determine the leading families of fishes equally as well in the dark as in the light, by simply passing his hands over their bodies. Here are a number of specimens before us. Note the arrangement, position and number of the fins, some prickly, some soft-rayed, some adipose; the scales of different shapes and sizes, large, small and indefinable: the opercles or gill-covers round, ovate, elongated; tails forked, crescent-shaped, square; snouts elongated, snubbed or retrousse; mouths of varying sizes and shapes, some bristling with teeth, others smooth as an infant's gums. A blind man should be able to read all these signs with more accuracy than the embossed literature of asylums.

Everything in nature has its counterpart. There are analogies throughout all the kingdoms of creation. If we reason from analogy we are not liable to go far astray. Observation made by actual comparison must be correct, as a general rule.

That we discover that fishes have all the five senses; that they can see, hear, taste, smell and feel; that they think, reason and sleep; that many of them produce vocal sounds, some of which are strictly musical. The stories of the singing fish of Ovid, Pliny, and other ancient writers, are not mere fables. I suppose I have myself heard vocal sounds from at least a dozen varieties of fish, notably, the sheepshead, or river drums of Western lakes, and the malasheganies of the great lakes, and on the sea coast the gurnards and drums. The drums are often heard on the ocean bottom, while the sea robins, weak fish and grunts always croak when lifted by the angler into the bottom of the boat. It is even maintained by some accepted authorities that fishes can communicate with each other by sounds. If they can they have never told me, and had they done so I should be too gallant to give away their secret. But although $I$ have not heard them converse in ichthyo language, I have noted the wink of the eye, the twirl of fin, the sign manual, and the tactical movement, which would do credit to stage pantomime or a plain Indian.

In the Western river drums, or sheepshead, the sources of the sounds are two small ear bones (located in the head, of course). They are of the size and shape of tamarind stones, and when dry resemble milk quartz. They are popularly known as "lucky stones," and many persons carry them in the pocket to woo the fickle Goddess of Fortune.

Fishes of the same river and brook have different complexions and varieties of visage. Those who are familiar with them, as fish culturists, or those who 
propagate them, can distinguish some of them from others as readily as a farmer can the cows or sheep of the same herd or flock. Fish, however, change their complexions, and are liable to become light colored or dark, according to the surroundings, just as men become pale in the office or house, and tanned, freckled or reddened in the sun.

Trout, having no perceptible scales, and a skin of delicate texture, are more sensitive than any other fish. Seth Green boldly declares that "trout can be bred to any color, shape or flavor, by feeding and change of ponds, with as much nicety and certainty as a cattle fancier breeds his animals."

It is a physical fact that all wild beasts, birds, reptiles, and even insects assimilate to the color of the surroundings.

All fish, like other creatures, have their diseases and their enemies. Most especially are they troubled with parasites and entozoa. Each family of fish has its own particular parasite, and none other. These generally attach themselves to the bodies of the fish behind the gills or fins, so that they cannot be rubbed off, and suck their substance until they die. There are no less than 126 kinds of tremotoda, or "fluke," found in fishes. (See Dr. Cobbold's Synopsis of the Distomidæ.) The treads worm and tape worm are the most common entozoa. Two years ago 1 fished the river Godbout, on the Lower St. Lawrence, and found them in every trout and salmon taken. They infest the intestines, and I cannot learn that the flesh suffers detriment therefrom or that injury results from eating it.

There is a great water beetle which is the especial enemy of the trout. It is about three inches in length, has large, strong wings, long sharp mandibles and sharp, hooked claws. It is equally at home in the air. in the water and on land. It can fly, swim and run. For the poor trout which it has marked for its victim there is no escape. If the fish attempts to flee through the water, it pursues; if it rises to the surface, instantly the bettle rises in the air, and hovering over it like a hawk, pounces on its back and fixes his inexorable claws into its flesh. Then it attacks him with its beak, and so destroys him. No Nemesis was ever so persistent.

Like the rest of animate creation, fish do not all live or feed alike, or occupy the same localities. There are fish carniverous, vegetarian and insectivorous; fish predatory and fish pastoral; fish local and fish migratory Fish also adapt themselves to their various requirements of temperature, quality of water, shelter, security and reproduction. The angler who studies their habits, of course, knows where to find them.

Take the great lakes for example. Where the shores are precipitous and rocky and the water deep no fish will be found, because they can find neither food, shelter nor spawning bees. Knowing this, the fishermen waste no time in useless quest, but follow them to the shoaler water, shelving beaches and sheltered coves, where they sweep them in with seines by myriads. In the winter these bays and coves are covered with ice, and the fish naturally resort there for shelter from storms and for warmth and food. Then the fishermen congregate to the spot by hundreds. Whole villages of huts cover the ice field, and men, women and children are busy day after day catching them with hook and line through holes cut in the ice. The fish are easily captured, for they are desperate for fresh air. The greater part of the oxygen has been exhausted from the long pent-up water, since the lake first froze, and they rush to the holes for atmospheric air. just as half-suffocated persons would do to an open window in an ill-ventilated room.

Fish live on air, like animals. Their gills are their lungs; just as our warm, red blood is purified and restored in its vital and arterial qualities by air passing 
through our lungs, so is the cold, red blood of fish by passing through their gills; and as by the process of breathing we extract the oxygen and vitiate the air, in like manner do fish taking the water in their mouths, extract from it the air held in suspension, and pass it out under the opercles, or gill covers, in a vitiated state. A fish can be drowned in the water almost as easily as an animal, when the water is prevented from passing over the gill covers in the usual way. For this reason. fish seldom swim down stream for any great distances at a time, and always "heave to," as sailors would say, head up stream. Anglers take advantage of this knowledge and kill their captives secundem artem. Often fish actually die in smaller lakes and ponds when closed by ice simply for want of air, and when their dead bodies are found floating on the surface in the spring, after the ice has broken up and melted, people wonder at the mortality, and speculate upon the cause of the mysterious (?) epidemic. If they had thought to cut holes in the ice at intervals throughout the winter this great waste of fish food might have been prevented.

It is this constant drain upon the fish supply at all seasons of the year. in and out of spawning time, which excites a well-founded apprehension that it will soon give out, especially in Lakes Erie and Michigan, where the shores are favorable for fishing and the fishing stations numerous.

As in the great lakes, so in the rivers and creeks, the small lakes and ponds, fish will be found where the conditions already specified are the most favorable.

Black bass spawn in May, seeking some retired spot in shallow water where they scoop out nests in the sand and gravel, and glue their ova to pebbles on the bottom, standing guard meanwhile near the deposit to keep off predatory intruders. It is this fidelity which makes the black bass so prolific. Other fish usually lose 95 per cent of their spawn. Affter ten days or so the young fry hatch out and scatter into deep water, where they are comparatively safe from predatory fish. This is a masterly precaution. Most fish fry keep near the shore, and thereby fall a prey to skulking pickerel, perch and sunfish. Bass are not the spawn destroyers which some suppose them to be. They are omnivorous and content themselves with larvæ, beetles, crayfish, water fleas and helgramites, varying their diet with occasional meals of fish-but not always on Fridays.

From June to August the best fishing places are in deep pools of rivers or under the shadows of dams and falls. From the middle of September to the end of October they seem to resort more to the deep currents of the midstream. In lakes they lie under the brush of fallen trees or along the edge of lily pads which line the shore, and near submerged points of rock. Very often they are found near sunken ledges of rock in the middle of the lake. They take the fly, grub, minnow or trolling spoon.

Trout are well scattered during May and June, both in lake and river. In streams and rivers they are most surely caught where the current is obstructed by boulders. Later in the summer they are found in deep holes where there are cold bottom springs, and by September they seek their spawning beds. They take fly, grub, worm and minnow.

It is pretty hard to tell a novice where to find trout. An expert angler will lose no time in testing doubtful or impracticable places, but seems to know the correct spots by an intuitive perception. In May or June, if he discovers a clump of overhanging bushes such as certain ephemera would use to deposit their eggs on, he will be apt to cast his line there, knowing that the pupa cases are ripe and liberating the flies, and that there the trout will congregate to feed. If he detects a stream trickling down the bank, carrying the landwash from the muck and rotten leaves above, he will put in his hook there, because a good supply of larvæ and 
vegetable food will float in wit? the debris. Thus he puts some trifling knowledg! of natural history to good practical uses. Indeed, without such knowledge no one can be a first-class angler.

Angling books and tackle dealers are apt to lay great stress upon the importance of selecting particular flies for the different months or for the different parts of the day and the varying moods of weather. A very thin stratum of logic underlies this theory, based simply upon the fact that certain species of flies hatch out at different times; to which may be added the reasonable and evident truth that bright flies are best on dark days and neutral tints in sunlight. As a rule, trout will take almost any kind of artificial fly except when some certain variety of natural fly is prevalent, and then they will take only a correct imitation.

My own stock of flies is always large, but is seldom drawn' on, except for a few certain sizes adapted to the season and weather. I don't go so much into the nice perception of varieties as books would have us infer that expert anglers and wise trout do. Nevertheless it is necessary that dealers.and makers should have an infinite assortment of devices and combinations of colors and materials with fancy names: and any angler of notorietv who is not an adent in the vernacular, and wise in supposed occult mysteries of the art, is in danger of being voted an ignoramus and a pretender.

Trout accustom themselves to a particular kind of food; and then they wili take no other. This has been ascertained by fish culturists. They can be taught to confine themselves to an exclusive diet of liver, maggots, curds or fish.

On the north shore of Lake Superior, where the shores are rocky and precipitous and the water very deep, they can scarcely be caught with any bait but minnow, because they get no other food there. Still, they do not altogether lose their natural instinct to pursue any moving object, and sometimes fasten to a Hy. 


\section{CHAPTER XXIV.}

\section{"FYSSHE AND FYSSHEYXge" (CONClUded).}

[Before the Minnesota Academy of Sciences, 1881.]

To enumerate the habits of the long list of so-called game fishes and describe their habitat and the different modes of capturing them would occupy a large volume. Such a book I published not long ago, after two years of laborious preparation. It is called the "Sportsman's Gazetteer," and embraces upward of 900 pages of print.

I have already spoken of the antiquity of angling. Professor J. J. Manley, of London, has collected sundry Biblical references to its early history. Job says: "Canst thou draw out leviathan with a hook, or his tongue with a cord which thou lettest down? Canst thou put a hook in his nose, or bore his jaw through with a thorn?"

From this brief passage it would appear that only hand lines or drop lines were in use in Job's period. I assume that rods were then not known. The hooks were made of wood, and quite probably of literal thorns. Even in the present day the Indians of Arizona and California use for hooks the thorns of a species of cactus, which are very tough and bent to proper shape by natural growth. The points are very sharp, and I should much prefer them to many of the inferior modern hooks, which are poor quality and badly tempered. All aboriginal hooks are made of wood or bone and are without barbs. The Japanese use barbless hooks, and it is worthy of remark that many modern anglers advocate the primitive pattern. Seth Green will not use hooks with barbs.

In the books of Habakkuk we read of fish being taken with an "angle." Isaiah speaks of those who "cast their hooks into the river," indicating evidently that rods were then used.

Angling with rod and line, and with the hand line alone. were practiced and well understood early in the Christian era. In the New Testament we read of Peter taking a fish with a hook; and furthermore it had a piece of silver money in its mouth! However, there was nothing strange about that. We read every season of fishes being caught with miscellaneous collections in their pockets sufficient to stock a small museum. The accidental dropping into the water of a silver coin and its pursuit by a fish which darted after it led to the invention of the spoon hook or troll.

It does not appear that reels were in use in the early centuries. The reel is an invaluable adjunct to facilitate the capture of big fish; and to take in a fiftypound anthia from Lake Tiberius or the classic streams of ancient Greece without one must have required the skill of an expert worthy to chalk his name high up beside those of the most illustrious anglers of modern times.

Here is a graphic description of fishing with a rod, written by the poet Oppian in the second century. I find it in Manley's book. It would do justice to anything written since, and proves that the poet understood the art of angling thoroughly. It makes one feel that the fishermen of old were of the same stuff as brothers of the angle now : 
"A bite! Hurrah! the lengthening line extends! Above the tugging fish the arched reel bends! He struggles hard, and noble sport will yield My liege, ere wearied out, he quits the field. See how he swims, up-down-and now athwar The rapid stream-now pausing as in thought; And now you force him from the azure deep;
He mounts, he bends, and with resilient leap, Bounds into air! There see the dangler twirl, Convulsive start, hang, curl, again uncurl, Labor once more, like young Terpsichore In giddy gyres above the sounding sea, Till neared, you seize the prize with steady wrist, And grasp at last the bright funambulist."

"Funambulist" is a good word.

The writer evidently understood the risk of losing a fish when reaching out the hand to take him in. There never was a hooked fish so nearly spent that he did not shrink or start fron the hand thrust toward him-showing that he was not only on the alert, even at the point of exhaustion, but that he was suspicious and apprehended the fisherman's motive.

I can conceive of no better proof that fish have mental organization or instinct equal to animals of apparently higher order.

Do fish think? Do fish reason?

Undoubtedly they do. They have their plans and method, and lay out their schemes to capture their prey; to outwit man; to circumvent each other; to avoid or avert danger by precaution or flight; to remember and avenge wrongs. Endeavors are almost always made by some kinds of fish to bite the angler after they are caught. The gapings of the jaws are not merely convulsive gasps and nervous spasms of the death throes. I have watched the features of a pike and seen the malignity and malice in his eye-a genuine malice prepense. A monster muscalonge alive in the bottom of a boat is almost as dangerous as an alligator of size would be. Therefore anglers shoot them through the head with a pistol, or stun them with a club, or sever the vertebral cord with a pointed knife, before they lift them ir. Sword fish, which have been struck with a harpoon, often attack the boat which has inflicted the injury. The salt water bluefish (temnodon Saltator) is one of the most aggressive biters I know of. There is no doubt that their efforts to bite are often prompted by an instinct of reprisal. They are evidences of mental organism.

I have never seen one of the salmonidæ attempt to bite, although their nervous gasps are good imitations of his intention. I should as soon expect to be bitten by a calf as by a trout.

There are different dispositions in fishes as well as in animals, we all know. Indeed, the ferocity and unrelenting pertinacy of some marine species far exceeds those traits in any known land animal extant.

Yet I will say this for a trout, that notwithstanding his meek and gentle disposition, he will hold his own against big odds.

In the aquarium of Messenger Bros., in Boston, were placed an equal number of trout and black bass, perhaps a dozen of each, graded to even sizes and weightsfrom a pound fish to a fingerling. At the close of the "circus" two of each remained -the two biggest trout and the two biggest bass. These did not fight any more, nor attempt reprisals. The entente cordiale seemed perfect. Their complete resignation to the conviction that neither was able to swallow the other was beautiful to contemplate. In the tussle the bass had great odds, because they were armed with scale armor, spiny fins and strong teeth, while trout had only velvet doublets, no scales to speak of and delicate teeth. How a trout can swallow a bass half his size seens an enigma.

To grasp a big fish, even when he is quite exhausted by protracted exertions to escape, requires nerve and dexterity. You must seize him by the nape of the neck, and, with the thumb and finger firmly fixed behind the gill covers, lift him out of his element. 
To obviate his possible escape under any circumstances, anglers employ a landing net. This is a scoop net with a handle. It must be slipped slyly under the fish, so that he will not suspect, and then be deliberately lifted upward and forward. This maneuver requires practice. Many an impetuous bungler loses a goodly fish which the angler has earned or brought to net or gaff by consummate skill and dexterous toil.

The gaff is a large hook, some three inches across the bend, fixed into a handle from three to five feet long. It is used in the capture of salmon and muscalonge, for striped bass on the sea coast, and, indeed, for any large fish whose weight the line cannot lift. The fisherman is usually served by an assistant who gafis or, nets his fish after they are played out and brought to hand. ("Played out" is supposed to be a slang phrase, but this is the origin of it.)

It is worthy of mention that a fish on a taut line always keeps his eyes fixed on the angler, and watches his motions steadily, like a prize fighter; yet it is possible to slip a gaff or net under him without his observing it.

Referring to the instincts of fish, I have been very much in the migrations of the fish in the tributary streams of the Red River of the North. They comprise several distinct families of fish-pike, perch, pickerel, sheepsheads, moon-eyes, catfish and suckers-and yet they all move out of the streams together on the advent of frost, knowing full well that the streams freeze to the bottom, and that they would be imprisoned all winter in an icy coffin, if indeed they did not actually perish.

Many fish, however, enjoy a temporary suspension of vitality; and, after having been frozen up solid in blocks of ice, are as active as ever when thawed out.

Some kinds of fish possess the power of voluntary torpidity and remain apparently lifeless all winter. A very large number of families hybernate-just as bears, coons and various animals do-notably catfish, eels, etc. It is said that black bass hybernate.

Oppian, already quoted, also describes fishing from a boat, a very effective and popular method, as well as a comfortable and exciting sport. It is almost the only certain way of capturing large fish. He puts it thus:

"The fisher, standing from the shallop's head,

Projects the lengthening line and plunging lead;

Gently retracts, then draws it in apace,

While flocking anthias follow and give chase.

"As men their foe, so these pursue their fate,

And closely press the still receding bail.

Nor long in vain the tempting morsel pleads,

A hungry anthia seizes, snaps and bleeds;

The fraud soon felt, - he flies in wild dismay.

Whizz goes the line-begins Piscator's play!

His muscles tense, each tendon on the rack

Of swelling limbs, broad loins, and sinewy back.

Mark yon proud form, erect with rigid brow,

Like stately statue sculptured at the prow;

From wavy hand who pays the loosening rein,

Maneuvering holds, or lets run again!

And see! the anthia not a moment flags;

Resists each pull, and 'gainst the dragger drags;

With lashing tail, to darkest depths below

Shoots headlong down, in hopes to evade the foe.

'Now ply your oars, my lads,' Piscator bawls:

The huge fish plunges-down Piscator falls,

A second plunge, and lo! the ensangued twine

Flies through his fissured fingers to the brine. 
"As two strong combatants, of balanced might

Force first esay, then practice every sleight,

So these contend, a while a well matched pair-

Till frantic efforts by degrees impair

The anthia's strength, who, drained of vital blood,

Soon staggers feebly thro' the foaming flood,

Then dying, turns his vast, unwieldy bulk

Reversed upon the waves, a floating hulk.

"Towed to his side, with joy Piscator sees

The still leviathan. Still on his knees,

With arms outstretched, close clasps the gurgling throat,

Make one long pull, and hauls him in the boat."

There is a true piscatorial ring about Oppian's epic, but the ancient tackle was evidently of rude construction. His fishermen used a simple handline, with a squid or jug for bait. A squid is a piece of lead some three inches long, fashioned in the shape of a fish and attąched to a hook. It is polished bright and glitters when drawn through the water. They are in use at the present day and not much improved upon the old patterns.

The ancient fisherman kept his squid in motion until a fish struck it, and then handled his captive after a fashion which would not much enjoy the "ensanguined twine" cutting the fingers to the bone. One capture would be likely to suffice, and they would not be apt to come across another "first-rate day of fishing" for some time. To obviate such distresses the modern angler uses a rod and reel, as well as a rubber thumb-stall or a thick woolen mitten to protect his hand. I have seen a muscalonge or a striped bass make such a swift and impetuous rush that the line would have cut the fingers clean off if it had been held in the hand. I have seen a salmon-reel so hot from friction that the hand could not bear the heat.

Jointed rods were not known to the ancients, though the present day really the best wooden rods are in one piece. Ferrules being less pliable than wood, impair the flexibility which should be distributed uniformly throughout the length of the rod. The advantage of sectional rods is that they are more portable, though in the cases of the split bamboo, the most artistic and effective rod made, the advantage of strength and flexibility are added from the very nature and plan of their construction. A split bamboo is ten-fold stronger and more pliable than the natural bamboo of which it is made. Calcutta bamboo is the best. The male canes only are used. They have less shoots.

The chief and primary object in fishing is to catch fish-to secure the object fished for. Therefore it would seem at first sight that the biggest rod, the thickest line and the strongest hook fulfill the condition of success. The first impulse is to lift the fish bodily out of the water by main strength and run no risk by fooling with him. The first remark made of fly-rod by a tyro is that it won't hold anything. This is true. Its uses are altogether different. The fact is one cannot catch any but the grossest and most stupid fish with clumsy tackle. Anglers don't fish in tanks with tame fish. Wild fish are shy, so the rod is made light and flexible to reach distant localities with a long line. It is rigged so as to fish the surface where groveling fish never come. Gross fish, like dregs, hug the bottom. The finer variety feed near the top. It is because no single rod ean do good, all-around service that trunk rods and combination rods are rejected by expert anglers, just as guns of different caliber, size and weight of ammunition are essential for different kinds of game.

The passion for angling is so strong that ardent anglers get to iove the most repulsive creatures from their very association. They will impale bettles, thread 
worms, fondle maggots and grubs, and manipulate all kinds of crawling. longlegged things without a qualm or shudder. Even ladies will do this with a keen zest. They enjoy the preparation of the seductive lures which are the accessories to the practice of the high art and are to add to their list of ichthyic trophies. Some of the fish culturists have maggot factories, to manufacture the daily food supply for their schools of fish. If people who buy home-made trout in the market at $\$ 1$ per pound only knew how some of them were bred and fed, they would hardly esteem them the delicacy they do. For myself, I don't stomach artificially raised trout of any kind.

Some of the best anglers in the two hemispheres are ladies-many of them of highest rank. Queen Victoria's daughter, the Princess Louise, and Lady Dufferin, wife of the late popular Governor General of Canada, have no superiors of either sex. Daniel IVebster's wife was the most complete angler; so is the wife of one of the leading officials of the Hayes administration. The Rev. W. H. H. Murray's wife, of Adirondack fame, is even a better angler than himself. Miss Sarah McBride, of Mumford, N. Y., is a most accomplished entomologist, as well as a practical angler. Indeed. the number of good lady anglers is greater than is supposed.

Lady Dufferin, on the river Restigouche, in New Brunswick, Canada, once struck a salmon at four o'clock in the afternoon, and hung to him until it was so dark that she couldn't see; but her gaffer finally gathered him in. There was pluck and endurance! The fish weighed twenty-eight pounds.

When I was a boy I used to carry worms in the toe of an old shoe in my vest pocket. I have often held worms between my lips for convenience when both hands were prooccupied. They had scoured themselves thoroughly in the dry sand and were nice and clean, red and plump, but squirmy. I never went so far as to make z bait box out of my mouth, like Nigger Sam.

Sam had a basket and pole over his shoulder, and was striking out for the creek. evidently going a-fishing.

"Hallo, Sam!" said a gentleman he chanced to meet." "What are you going to catch this time?"

"Yum-yun-yum-yum."

"Anything the matter? What have you got in your mouth?"

"Wums, for bait."

Some of the fishing outfits of the United States and Canada are extensive, expensive and complete, a few almost princely in their appointments. Allain Gilmour, Esq., of Ottowa, Canada, doubtless has the finest angling establishment in the world, which is maintained at an annual cost of $\$ 25,000$. His fishing privilege on the Godbout river includes 5,000 acres of forest and several miles of water; the station is a considerable hamlet of itself, arranged for every convenience and luxury; a beautiful steam yacht and steam tender are included in the outfit. Representatives of royalty are frequent guests at this establishment.

Willis Russell, an American resident of Quebec, has six cottages on the River Marguerite, which are comfortably appointed for salmon anglers.

Col. William H. Rhodes, of Quebec, and William Hare Powell, of Philadelphia, have luxurious establishments at Tadousac, on the lower St. Lawrence.

C. J. Brydges, of the Grand Trunk Railroad, has a luxuriously appointed scow on the Restigouche, with gallery, dining hall, state rooms, promenade deck, etc. It is drawn up stream by horses and is named "Great Cæsar's Ghost." The Princess Louise and Lady Dufferin have both honored this quaint craft with their patronage. 
On the same river is a club of American gentlemen, who pay $\$ 1,000$ a year each for their fishing privilege.

Most of the Canadian salmon rivers are leased at $\$ 200$ and upward, the lessees all having expensive quarters and outfits.

"Fysshe and Fyssheynge" have their quaint and humorous features. I doubt if any avocation or pastine has more of them. One of the most grotesque conceits in angling literature is the poem entitled "The Skeleton Angler." It will do very well for "last words" to this paper. The author of the verses was a London tackle dealer, and the effusion appeared originally as an advertisement of his goods. It is really a remarkable piece of fanciful imagination. I have copied it from Manley's clever book. It runs thus:

"When the clock in yon gray tower

Proclaims the deep, still, midnight hour,

And ominous birds are on the wing,

I rise from the realms of the Bony King.

"My bonny elm coffin I shoulder, and take To fish in the blood red phantom lake, Where many a brace of spectral trout

Forever frisk, dart and frolic about.

"Then the hyena's ravening voice

Gladdens and makes my heart rejoice!

"The glow worm and the deaths-head moth

Are killing baits on the crimson froth.

"For work bench I've the sculptpred tomb,

Where tackled form by the silent moon;

Of churchyard yew my rods I make;

Worms from the putrid corpse I take;
Lines I plait from the golden hair

Plucked from the head of a damsel fair;

Floats of the mournful cypress tree

I carve, while night winds whistle free.

"My plummets are moulded of coffin lead;

For paste I seize the parish bread.

The screech-owl's or the raven's wing

For making flies are just the thing!

"Should thunder roll from the barren shore,

I bob for eels in the crimson gore,

A human skull is my live-bait can,

My ground-bait the crumbling bone of man,

My lusty old coffin for punt I'll take,

To angle by night in the phantom lake.

"While Dante's winged demons are hovering o'er The skeleton trout of the crimson gore,

To the blood-red phantom lake I go,

While vampyre bats flit to and fro."

Afterward follows an epigram: Scene, sunrise.-All the phantoms and obscene creatures out of sight in their little beds, and the author of the verses cheerfully at work in his shop at Hungerford market, where all good fishermen are respectfully invited to call.

The pathos is really too shocking to inflict upon an imagination wrought up to the supreme pitch, and therefore I spare my readers the collapse which a perusal of the lines would be sure to entail. 


\title{
CHAPTER XXV.
}

\author{
PROGRESSIYE FISH CULTLRE.
}

THE entire number of fishes inhabiting the waters of the United States is something over 1,400 . More than 300 of these have a recognized economic value.

The first attempt at artificial fish culture in the United States was made by Dr. Theodatus Garlick in 1851.

Massachusetts established the first board of fish commissioners in 1856 , to consider the practicability of artificial propagation.

The era of practical fish culture was inaugurated in 1864. by Mr. Seth Green.

New Hampshire appropriated the first public money for fish cultural purposes in 1865. Massachusetts organized the first state fish commission in 1866.

The United States Fish Commission was established in 1871.

The American Fish Cultural Association was established in the same year.

Fish hatching was first publicly shown at Coup's Aquarium by Fred Mather in 1875 .

The first exhibition of fishing appliances was made by the Smithsonian Institution at Philadelphia in 1876.

Carp were introduced in $187 \%$, and since then have been planted in 20,000 localities in different parts of the country.

Floating hatcheries were introduced in 1877.

The propagation of marine fishes was first undertaken in 1878 .

In 1880 the grand prize of the International Fisheries Exhibition at Berlin was awarded to Prof. Baird as "the first fish culturist in the world."

The steamer Fish Hawk was built for the U. S. Fish Commission in 1880.

The steamer Albatross was put in commission in 1883.

Thirty states and territories now have fish commissions.

The total amount of public appropriations by the United States and the several state commissions up to the present year has been fully $\$ 2,500,000$.

The weight of edible fish taken from the waters of the United States is two thousand million pounds annually, or about forty pounds to each inhabitant.

The value of the annual fish product is $\$ 45,000,000$.

The number of persons dependent on the fisheries is one million.

About 12 per cent of the whole number of fishermen are foreign-born.

The principal commercial fish products are: Oysters, cod, salmon, whales, menhaden, fur seals, mackerel, shad, alewives, herring, sardines, clams and quahogs, whitefish, lobsters, sea otters, halibut, crabs, haddock. sturgeon, mullet, shrimp and prawns, eels, sponges, abelones, seals and sea elephants, hake, scallops, red snappers and groupers, smelt, turtle and terrapin. mussels, flounders, swordfish, sea weed, sea salt and Irish moss.

In the days of the early beginning a few varieties of fresh water and anadromous fishes were hatched in rude hatching troughs in small hatching houses, with primitive waterworks of insufficient volume, by Lyman, Green, Ainsworth, Slack, Stone, Atkins, Brackett, Mather and a few others, but in 1877 the United States Fishery Commission practically took the whole matter of fish culture under its charge as a national enterprise. While it eagerly availed itself of all the knowledge 


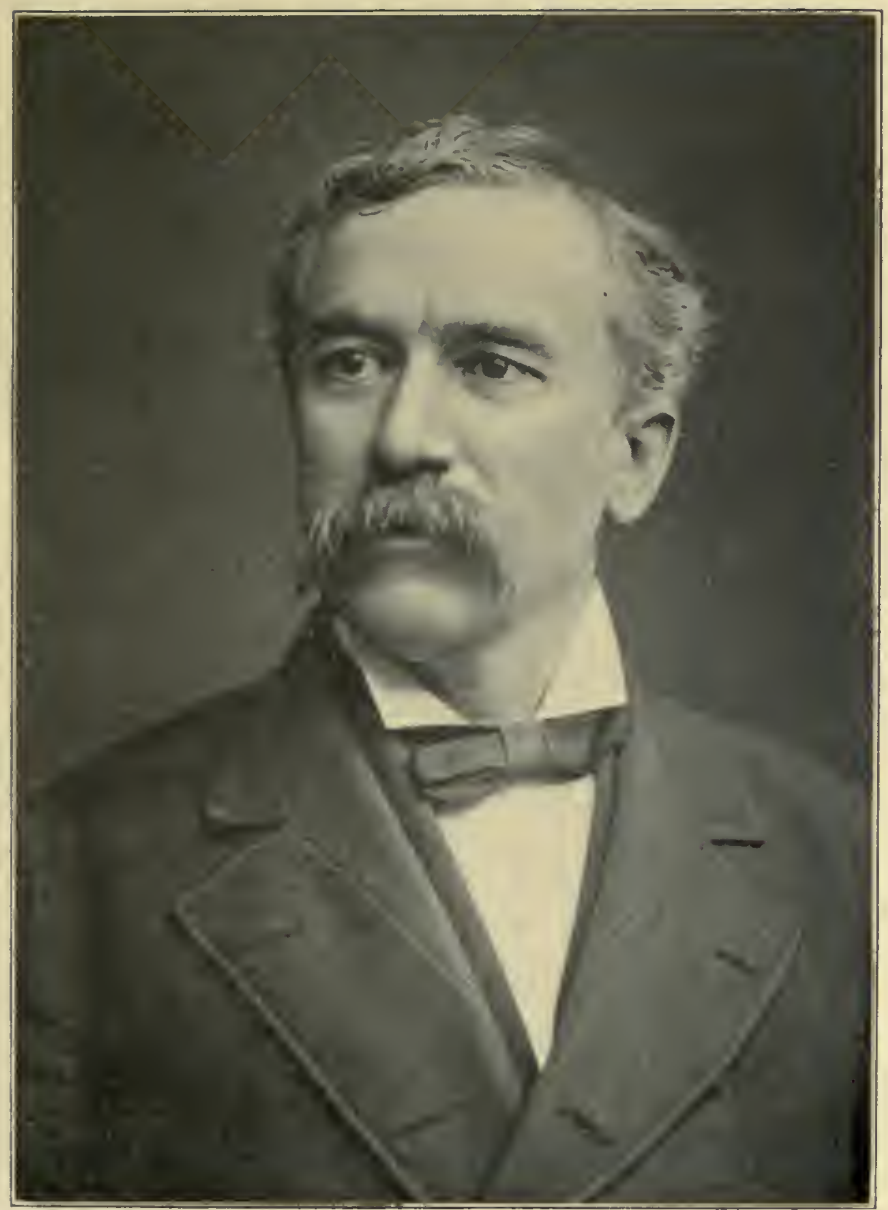

FRED MATHER,

ANGLER, AUTHOR, FISH CULTURIST. 

which had already been acquired on the subject, it at once undertook to devise improved methods and appliances to expedite the work and extend its scope. Within the interval marvelous apparatus in astonishing variety has been invented; and each new experience gained has enabled it to improve upon the old styles of boxes and troughs, or necessitated the invention of new devices adapted to special requirements. For instance, heavy eggs, like those of salmon and trout, require one kind of hatching apparatus and a particular mode of treatment; semi-buoyant eggs, like those of whitefish and shad, another kind; adihesive eggs, like those of smelt, herring and perch, another; floating eggs, including those of cod, Spanish mackerel and moonfish, a kind so arranged as to utilize the action of the waves.

Methods of fish culture have advanced equally with devices and apparatus. The most important of these is the building of movable floating hatcheries in the form of barges, and steamers like the Fish Hawk and Albatross, the last named being 1,000 tons burthen, and both fitted with every known convenience and appliance. By means of these steamers the results of the work are enormously increased, with a comparatively small increase of cost, for instead of the hatcheries being stationary, and operating at only one point, they may be moved from place to place, following the migrations of the fish, as the season advances. Steam is a most important auxiliary, too, for pumping water and working the various kinds of apparatus.

With regard to transportation, immense quantities of fish and eggs are distributed by means of refrigerator cars built expressly for the purpose, whereas they were formerly carried in small quantities in the baggage cars of ordinary passenger trains.

Up to the present time thirty principal species have been artificially hatched. These comprise the following: Brook trout, whitefish, lake trout, pike-perch, Atlantic salmon. shad, California salmon, striped bass, land-locked salmon, Oquassa trout, sea bass, grayling, sturgeon, smelt, herring, alewife, oyster, cod, haddock, carp, Spanish mackerel, cero, moonfish, silver gar, gold fish, tench, mountain trout (S. irridca) and soft-shell clams.

There were thirteen principal hatching stations operated by the United States Fish Commission in 1883, to wit: Grand Lake Stream and Bucksport, Maine; Wood's Holl, Mass.; Cold Spring Harbor, Long Island, New York; Havre de Grace, Maryland; Washington, D. C.; Wytheville, Va.; Point Lookout, Md.; Avoca, N. C.; Northville and Alpena, Mich.; Baird, Cal., and Clackamas, Ore.

Since the year 1877 the entire North Atlantic Coast from Florida to Nova Scotia has been made the seat of the most active operations in marine research. Temporary laboratories are set up along the coast wherever required, and the business of dredging, seining, collecting, classifying and preparing museum specimens is prosecuted with the utmost vigor. There is a permanent headquarters at Wood's Holl, in Massachusetts, where, in addition to. other scientific work, the propagation of sea fishes is carried on extensively, and there are also stations of observation and labor in every important position of the coast and interior waters, where the breeding times and habits and the embryology of a great variety of fishes are studied, as well as special problems of temperature of water. movements of fishes, causes of mortality, the varieties of fnod, and the nutritive value of fishes, etc.

But not only does the U. S. Fish Commission undertake this multifarious work through its own designated agents, experts and assistants, but it impresses into its service the whole fishing fleets of the North Atlantic, the signal offices of the army. the lighthouse keepers and lightships, the life saving and signal stations along shore; and it stimulates their exertions and their interest by public praise and by printing 
their discoveries. A great many fishing vessels carry collecting tanks. In this manner some 60,000 specimens have been obtained and over thirty species of fishes have been added to the known fauna of North America.

All these facts and many more were contributed by Prof. R. Edward Earll to the data which Prof. G. B. Goode submitted in his address before the International Fisheries Conference at London, in 1883, and which have recently been printed. They show not only the tremendous scope of the work in hand, but the large discretionary power which the commissioner enjoys as one of the pet factors of the government. One of its duties is to suggest to Congress any protective, precautionary or prohibitory measures necessary for the rehabilitation of the waters of the United States. It has been so instructed. Now the commission has promised the people an abundance of fish, so that all may eat and be filled. It has promised them fish without legislation; and while it does not affect to despise state legislative enactments as indirect aids to protection and propagation, it forbears to introduce the law into the hatching box. It declares, in effect, that hereafter fish shall be so plentiful that protective laws will be superfluous and that anglers shall enjoy the privilege of fishing without paying for it. Such a consummation will remove all disputes about riparian rights and take the gilt edge off from the eclat which attaches to club membership. In the halcyon days of that coming anglers' millennum trespass notices will not be any more required for private trout waters than they are for hen-roosts. The occupation of the big bulldog will perish, and the last exacerbated trousers-seat will be hung up in the National Museum as a memento of the dampness which once hung around a fisherman's luck.

NotE. - The foregoing chapter was written in May, 1885.-EDrtor. 


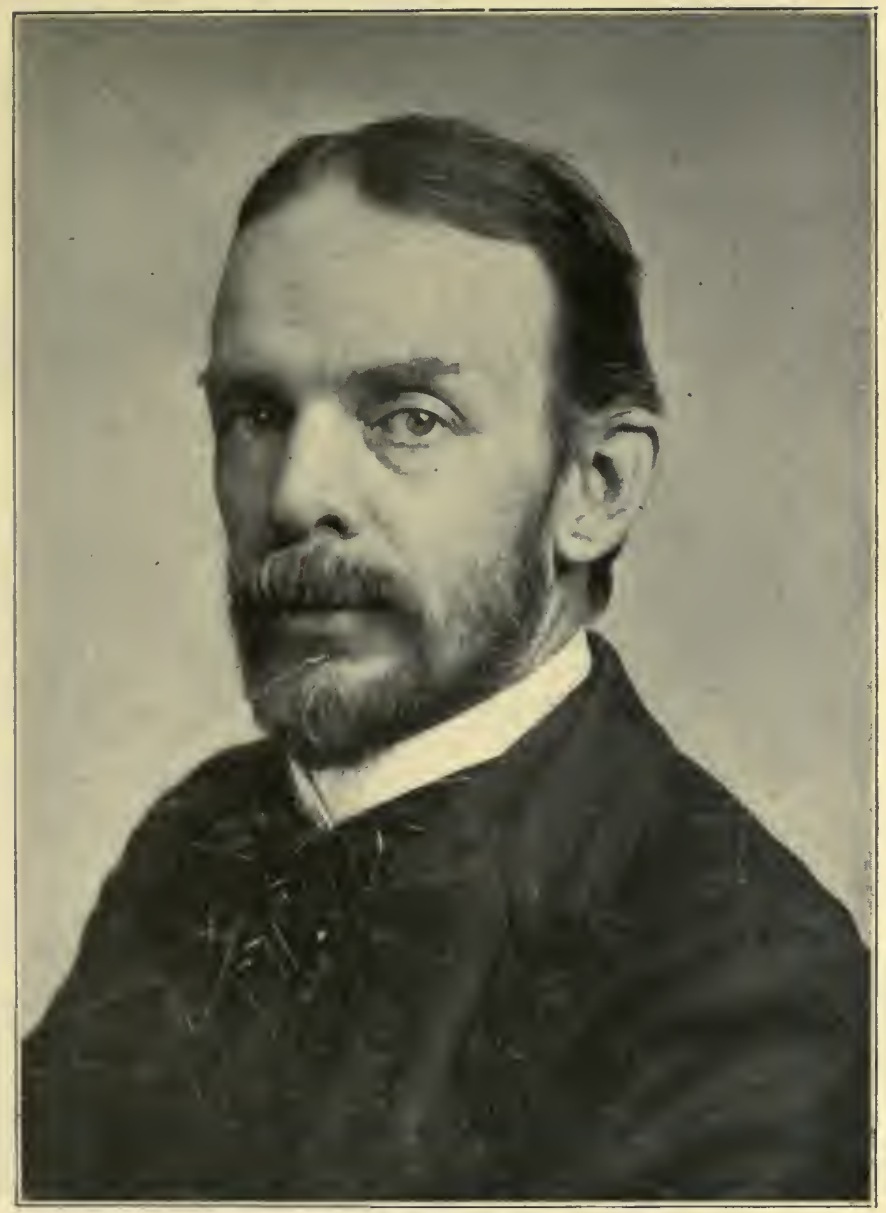

G. BROWN GOODE,

FISH CULTURIST AND AUTHOR. 


\section{CHAPTER XXVI.}

RECORD OF LIFE WORK FOR FIFTY-EIGHT YEARS.

1852-5-Compositor and reporter, New York Journal of Commerce.

1853-6-Contributor to many sketch and story papers.

185.5-6-Assistant editor New Haven Register.

1856-Senate reporter, Connecticut Legislature, O. H. Platt, clerk

1856-61-Associate editor New York Journal of Commerce.

1857-The Siege of Ft. Atkinson. Experiences on the plains. (See Harper's Magazine, October, 185i.)

1858-Visited Red River of the North (Harper's Magazine), April and May, 1858.)

July, steamboat War Eagle, from St. Paul (4:30 p. m.) to Prairie du Chien (9.15 a. m.).

Via first railroad from Prairie du Chien to Chicago opened.

1859-Opened the Aroostook to agriculture. (Journal of Commerce.)

(Harper's Monthly.) Visits to Madawaska. Life among the loggers.

1860 -First photos of interior Labrador. (Harper's Magazine.)

1861-Sea Islands of Georgia (Harper's Magazine.)

1862-Correspondent Morning Journal, Halifax, N. S.

1863-Assistant editor Chronicle and Sentinel, Augusta, Ga.

Temporary Editor Royal Gazette, Bermuda.

Worked up resources of Maritime Provinces for the St. John Telegraph, and Halifax Citizen.

1864-Assistant editor Telegraph, St. John, N. B.

1864-5-Chief editor Courier, St. John, N. B. (Confederation organ.)

1865 -Editor Humorist, St. John, N. B.

1861-66-Broker and commission merchant at Halifax and St. John. (Firm of

Wilkinson, Wood \& Co., and Hallock, Schroeder \& Co.)

1867-Broker, 59 Beaver, New York. (Ralph King \& Hallock.)

Oyster Point town site, in New Haevn, laid out estate in streets and lots.

1868-Financial editor Harper's Weekly.

The Restigouche, Bay Chaleur. (Harper's Magazine, December, 1868.)

1869-Worked up the Adirondacks. (Harper's Magazine.)

1870-71-Founded Blooming Grove Park, Pa., with Fayette S. Giles.

The first game preserve in the United States.

Sheldon Wood Preserving Co., creosoted wood pavement.

Electric boiler cleaner. Catalyzed paper. (Sunk a lot of money in these ventures.)

1872-Chatham, Nova Scotia, for salmon and canned lobsters.

Prospected north shore of Lake Superior for mineral.

1873-Wrote "The Fishing Tourist."

Founded Forest and Stream.

Director Flushing and Queens County Bank, L. I.

1874-Founded International Association for Protection of Game. 
1874-6-Opened Lake Okechobee and Florida sugar planters to tourists, with Fred. A. Ober, naturalist and historian.

1875-Among the buffalo in the Indian Territory.

1876-Published "Camp Life in Florida." (350 pp.)

Sportsmen's exhibit at Philadelphia Centennial. (Hunters' Camp.) Medal

1877-Wrote "The Sportsman's Gazetteer" (900 pp.)

1878-Worked up moonshiners in Tennessee and North Carolina for New York

Herald, with Major Wagner's mounted revenue police.

Worked up Northern Michigan for G. R. \& Indiana Railroad.

1879-Founded town of Hallock, in Kittson County, Minn.

1880-Published "Dog Fanciers' Directory and Medical Guide."

Built Hotel Hallock, at Hallock, Minn., and exploited town site; now a thriving county seat.

1880 -Donated $\$ 5,000$ collection to Long Island Historical Society.

1881-Offered to Chicago the first smoke consumer and garbage burner. (My own invention.) Introduced steam gauge for boilers. Handled combination standpipe and fire escape.

Worked up Northern Pacific Railroad west to the Rockies.

Life in Montana and Idaho.

1882-Worked up Canadian Pacific west to Regina and Moose Jaw.

Winter research in Texas, Arkansas and Missouri.

1883-Sunflower culture for its oil product in Northern Minnesota.

1884-Successful culture in Minnesota of sunflowers for the oil product. (See

U. S. Agricultural Dept.)

South Carolina, Etowah, phosphates near Charleston.

Tried to introduce automatic garbage consumer.

Etowah phosphates, South Carolina rivers.

1884-5--Superintendent Minnesota Frontier Exhibit at New Orleans Fair.

1885-Reported Manitoba Riel Rebellion for New Orleans Times-Democrat.

Exploited chemical coal economizer on steamers and tug boats.

1886-92_-Worked up Massachusetts' abandoned farms.

1885-6-Visited Alaska and wrote "Our New Alaska."

1887-8 - Prospected for phosphates and marble in Ontario, Canada.

1889-90-Worked up Montana mineral district for Great Northern Railroad.

Wrote up Yellowstone Park for Chicago Field.

1890-Wrote "The Salmon Fisher," edited Nature's Realm ten months.

1891-Introduced through Senator McMillan bill to establish Industrial Indian School in Pipestone, Minn., southwest corner.

1888-92-Worked up resources of Virginia and Eastern North Carolina. (Tidewaters.)

1892-Worked up British Columbia for Great Northern Railroad. (Lethbridge to Spokane.)

1893-7-Basket willow culture in North Carolina.

1894-6-Business agency and truck farm at Newbern, N. C.

1895-7-Director State Dairy Association of North Carolina.

1896-7-Edited Western Field and Stream, St. Paul, Minn.

1897-Formulated a code of uniform game laws, which has been officially indorsed by the U. S. Biological Survey.

Life in Mississippi, Tennessee and Alabama. 
1898-99-Mining broker in St. Louis, Mo.

Life in Mississippi, Tennessee and Alabama.

1900 -Worked up Mobile (Ala.) industries for Chamber of Commerce.

1901-03-Truck farming at Newbern, N. C.

190 - Half century class record (1854) Amherst.

1905-Natural history of Southern California.

Built studio at National City.

1906- "Luminous Bodies." Metaphysical Pub. Co., New York.

1907-"Hallock Ancestry."

Resources of Eastern Long Island, N. Y.

Jamestown Exposition, at Norfolk, Va.

1908-"Peerless Alaska."

Eastern Long Island geophysics and natural history.

1909 - Engaged in literary work.

1910-11-Cosmogony for Harper, Antiquarian and Metaphysical Magazine.

Active or honorary member of fifty-seven scientific, literary and game protective societies. Member of D. K. E. Fraternity. Member of the Masonic Fraternity since 1857. Member of the Grange. Have done continuous work for Smithsonian since 1860. Have visited nearly every geographical division of North America, from ice to tropics. Have cruised the entire Atlantic coast up to Greenland and one-half of the Pacific coast. Have run the blockade by land and sea. Contributed to Harper's Magazine off and on from $185 \%$ to 1906 . Have contributed to scores of magazines and papers. Correspondent for Evening Post from 1868 to 1899. Was stockholder of Journal of Commerce from 1855 to 1879 . Fitted Ober Expedition to Florida in 1874 and to West Indies in 1876. Am author of fifteen copyrighted works. Member of National Geographical Society and Biological Society, IV ashigton, D. C.

Attest: Charles Hallock. August 1, 1909.

\section{Charles Hallock's Club Memberships.}

(Active, Associate and Honorary.)

Honorary-Alaska Historical Society, Sitka.

Active -American Forestry Association, Minnesota.

" American Tract Society, New York.

“ American Ornithological Union, Boston.

" American Forestry Association, Washington, D. C.

“ Ancient Landmark, St. Paul, Minn.

Honorary-Anglers' Club, New York.

Active - Anglers' National Association.

" Art Collectors' Club, Philadelphia.

Honorary-Ausable River Game and Fish Protective Society, New York.

“ Beaver River Club, Springfield, Mass.

Active -Biological Society, Washington, D. C.

“ Blooning Grove Hunt Club, Pike County, Pa.

" Brooklyn Club. (1870-71.)

Honorary-Brooklyn Gun Club.

Active -Canadian Camp. (1905-9.)

Honorary-Central City Sportsmen's Club, Syracuse, N. Y.

" Central New Jersey Game and Fish Protective Society. 
Active -Cosmos Club, Washington, D. C.

“. D. K. E. Alumni Association, New York.

“ D. K. E. Alumni Association, Washington, D. C.

Honorary-Eagle Piscatory Club, Eagle City, Alaska.

Active -Faust Club, Brooklyn, N. Y. (1870.)

Honorary-Forest and Stream Sp. Club, Brainerd, Minn.

" Forest City Gun Club, Portland, Me.

“ Forest City Gun Club, Ithaca, N. Y.

“ Gaillard Sportsmen's Club, Natchez, Miss.

Active -National Geographical Society, Washington, D. C.

" Greenwood Lake Club, Montclair, N. J.

Honorary-Greenville Sportsmen's Club, Greenville, $\mathrm{Pa}$.

“ Gulf City Gun Club, Mobile, Ala.

“ Hallock Sportsmen's Club, Glens Falls, N. Y.

“ Hallock Sportsmen's Club, New Smyrna, Fla.

" Hallock Sportsmen's Club, Chicago, Ill.

" Haydenville Club, Haydenville, Mass.

" Jersey City Heights Gun Club.

" Kennebec Association, P. G. and F., Augusta, Me.

Active -Long Island Historical Society, Brooklyn, N. Y.

Honorary-London (Can.) D. G. F. and G. B. P. S.

" Longmeadow Gun Club, Minneapolis, Minn.

" Louisville Gun Club, Louisville, Ky.

" Massachusetts Fish and Game Protective Association.

" Minnesota Historical Society, St. Paul.

“ Minnesota Academy of Sciences, Minneapolis.

“ Multnomah Rod and Gun Club, Portland, Ore.

Active -New England Grenfell Association, Boston, Mass.

“ New York Sportsmen's Club. (1860.)

" New York Association Protection Game and Fish, New York. (1875.)

Honorary-Philadelphia Sportsmen's Club. (1870.)

Active -Philistines, East Aurora, N. Y.

" Plainfield Grange, Mass.

" Prisoners' Aid Association, Washington, D. C.

Honorary-Rod and Gun Club, Springfield, Mass.

Active -Social Science Association. (1901.)

" Tariff Reform Club, New York.

" Thirteen Club, New York.

Honorary-Tuna Club, Santa Catalina, Cal. (1907.)

Summary-Honorary, 29 ; active, 28 ; total, 57.

Club Membership in States.

Alaska

2 Minnesota ..................... 5

Alabama .................... 1 Mississippi $\ldots \ldots \ldots \ldots \ldots \ldots \ldots \ldots$

California .................... 1 Ontario $\ldots \ldots \ldots \ldots \ldots \ldots \ldots \ldots \ldots$

District of Columbia.............. 6 Oregon $\ldots \ldots \ldots \ldots \ldots \ldots \ldots \ldots \ldots, 1$

Florida ......................... 1 Pennsylvania .................. 4

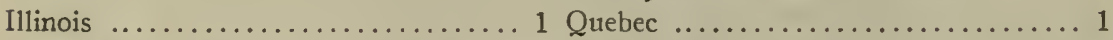

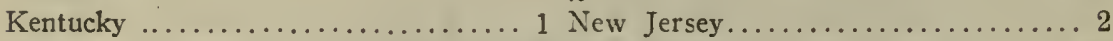

Maine ........................ 3 New York....................21

Massachusetts ................6 6

Total...........................58 


\section{Copyrighted Books by Citarles Hallock.}

1854 - "Recluse of the Oconee," Sunday Atlas. Herrick \& Ropes.

1863- "Sketches of Stonewall Jackson." Chronicle Company, Augusta, Ga.

1873 - "Fishing Tourist." Harper Brothers.

1876- "Camp Life in Florida." Forest and Stream Publishing Company.

1877-"Sportsmen's Gazetteer." Forest and Stream Publishing Company.

1877- "Vacation Rambles in Michigan." Grand Rapids \& Indiana R. R. Co.

1878- "American Club List and Glossary." Forest and Stream Publishing Co.

1880 - "Dog Fanciers' Directory and Medical Guide." Forest and Stream.

1880 - "Rub It Out." Crichton \& Co., New York.

1886- “Our New Alaska." Forest and Stream.

1890 - "The Salmon Fisher." Harris Publishing Company, New York.

1904-Half Century Class Record, ' 54 , Amherst, Mass. Carpenter \& Morehouse. 1906- "Luminous Bodies Here and Hereafter." Metaphysical Pub. Co., New York.

1906- "Hallock Ancestry." Carpenter \& Morehouse, Amherst, Mass.

1908 - "Peerless Alaska."

1909- "The New Cosmogony." (Not out.)

1909 - "Autobiography of an Old Sportsman." (Not out.)

\section{Magazine Articles by Charles Hallock.}

Harper, October, 185ī, "Siege of Fort Atkinson ;" April, 1859, "Red River Trail;" June, 1859, "Red River Trail;" March, 1860, "Life Among the Loggers;" July, 1860, "Hunting on Green Island;" April, 1861, "Three Months in Labrador;" May, 1861, "Three Months in Labrador;" October, 1863, "Aroostook and the Madawaska;" December, 1866, "Secrets of Sable Island."

Stewart's Quarterly, St. John, N. B., 1867, "The Paper of Century."

Harper, March, 1868, "The Restigouche;" August, 1870, "The Raquette Club."

Galaxy, April, 1870, "Bermuda and the Blockade."

London Field, 1887, "Angling Literature of America."

Goldthwaite, 1891, "Underground Water Courses."

New England Magazine, May, 1891, "Russian Fur Trade."

Goldthwaite Geographical Magazine, 1892, "Physiography of a Pocoson."

Springfield Republican, 1891, "Northwestern Minnesota."

D. K. E. Quarterly, 1893, "Old Times in Achaia."

University Magazine, 1894, "Metropolitan Workers of the Past Generation."

U. S. Government Report, 1894, "Monograph of the Reindeer."

New England Magazine, 1894, "A Gentleman's Estate;" 1892, "Bermuda in Blockade Times."

Railway Age, 1895, "First Railroad Train in Florida."

Southern States Magazine (three papers), 1896, "Old Field Homiletics."

Anthropologist, 1896, "Eskimo's Written Language."

National Geographical Magazine, 1896, "Two Hundred Miles up the Kuskokwin." Rat Portage Miner, 1897, "Pioneer Discoveries of Gold in Ontario.

Menorah Monthly, 1898, "Biology of the Cosmos.

Indians' Friend, 1900, "Employments for Indians."

Outing, 1900, "Pioneer Sportsmen of America."

Antiquarian, January, 1002, "Ancestors of American Aborigines."

Squire's Catalog, 1902, "Down by the Sea." 
Chubb's Catalog, 1902, "Etchings on a Salnon Stream."

Outing, 1902, "Marine Life on Alaska Coast."

Everybody's Magazine, July, 1902, "Delights of Salmon Angling."

Harper, August, 1902, "Prinitive North Americans."

Southern States Magazine, 1904, "Newbern in Bloom."

Wiseman, 1902-3, Electrical Body of Future Life," "Philosophy of Everlasting

Life," "Philosophy of Religion," "The United Philosophies."

Recreation, 1905, "The Minnesota Interlaken."

Maine Sportsman, 1906, "Hunting the Musk Ox."

SPORTSMEN's Review, 1906, "American Sportsmenship."

Determination, 1907, "Loves of Pocahontas."

Kindergarten Magazine, 1907, "Kindergarten by the Sea."

Field and Stream, 1908, "Vanishing Moonshiner."

Metaphysical Magazine, 1908, "Electricity the Vital Force."

Field and Stream, 1909, "Hunt of Irish Rifle Team."

\section{Essays and Mongraphs.}

\section{(Outside of stated newspaper work.)}

Halifax, N. S., 1863, “Joel Penman's Observations, or the Provinces through Yankee Spectacles;" 1864, "Sketches of Stonewall Jackson" (English edition).

New York Herald, 1876, "Still Hunting in North Carolina."

Minneapolis Academy of Science, 1880, "Fauna of Northern Minnesota."

St. Paul Pioneer Press, 1881, "The Black Canon of Wyoming.

New England Magazine, 1881, "Fysshe and Fyssheynge" (a lecture).

Chicago Field, January and February, 1882, "The Yellowstone Country" (5 papers);

1882, "Red River of the North:" "Lake of the Woods."

American Field, 1883, "The Turtle Mountain Country."

Brooklyn Eagle, 1883, "Development of Texas."

Pioneer Press, 1883, "The Southwest via Missouri Pacific Railroad" (10 papers). Chicago Field, 1883, "Chequamagon," "Roseau Lake Breeding Grounds," "Hegira of the Crows," "Wane of the Aborigines."

Orvis Cheney Volume, 1883, "Etchings on a Salmon Stream."

St. Louis Rural World, 1883, "Sunflower Culture for Its Oil Prodluct." American Field, 1884, "The Sea Trout."

Chicago Field, 1884, "Domesticated Buffalo," "Bob Blue and His Kinsfolk."

Chicago Field, 1881, "The Story of Oomingnoak" (musk ox).

American Angler, 1885, "Fish Distribution in the Northwest."

Chicago Field, 1885, "The Transcontinental Moose Path," "Buffalo in Texas."

St. Paul Pioneer Press, January to April, 1885, "New Orlcans Cotton Exposition."

New Orleans Times-Democrat, April, 1885, "The Riel Rebellion."

New York Sun, 1885, "Home of the Iceberg."

Chicago Field, 1885, "Old Shad Times on the Connecticut."

Forest and Stream, 1886, "Trout of Alaska."

New York Evening Post, 1886, "The Hampshire Hills."

Brooklyn Eagle, 1886, "Turkish Americans."

Washington Biological Society, December 3, 188i, "The Great Roseau Swamp."

Union Signal, January 13, 1887, "Women and Temperance in Alaska."

Washington Biological Society, March 19, 1887, "Transcontinental Range of the

Moose;" 1887, "Reversion of Domesticated Animals to Wild State." 


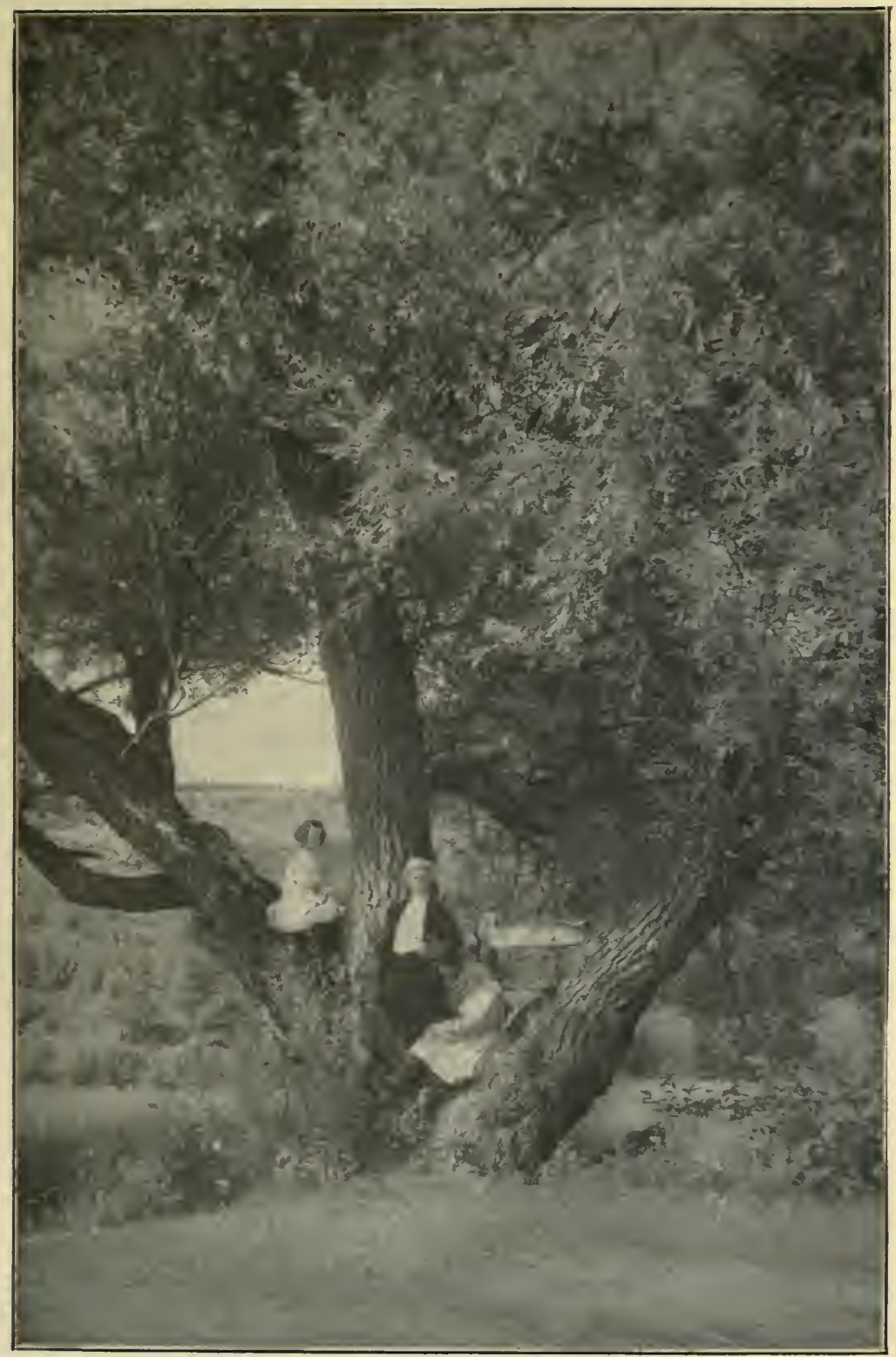

"THE DEAN," UNDER ANCESTRAL TREES, PLAINFIELD, MASS 

Magazine of American History, April, 188i, "Making of History in Alaska."

London Field, June, 1887, "Angling Literature of America."

American Angler, 1888, "In Quest of Grayling."

Evening Post, 1888, "A Yankee in Canada."

Forest and Stream, December 20, 1888, "Super Sense of Animals;" November 11, 1889, "Dogs of the Circumpolar World."

Charleston News, 1889, "The Voters' Milennium."

Raleigh News and Observer, 1889, "Qualified Sufirage."

New York Times, 1890, "Ocean to Ocean" (six papers).

Evening Post, 1889, "Lounging Along the Laurentides" (three papers).

Recreation, Washington, D. C., May, 1889, "Routes of the Russian Fur Trade."

Charles (S. C.) News, January, 1889, "Qualified Suffrage for All States."

New York Times, October, November, 1890, "Sketches of Montana" (six papers).

Sports Afield, 1891, "Midwinter Rambles in the Southwest" (six papers).

American Angler, October, 1891, "Memphremagog."

Goldthwaite's Geographicál Magazine, May, 1891, "Distribution of Fishes by Underground Streams."

New England Magazine, May, 1891, "Origin, Courses and Ethnography of the Russian Fur Trade."

Newbern (N. C.) Journal, 1891 (Slocum Letters), "Sketches of Newbern" (twelve in all).

Forest and Stream, 1892, "Winter Sports in North Carolina" (six papers), "The Kootenay Country, British Columbia" (four papers), "Canoe Routes of the Hudson Bay Company."

Evening Post, 1892, "Annapolis by the Sea."

Goldthwaite's Magazine, 1892, "Physiography of a Pocoson."

Forest and Stream, November, December, 1892, "Marooning in High Altitudes."

Iron Age, 1892, "Mesaba Iron Range" (IVisconsin).

Evening Post, 1893, "John Coona at Christmas."

Chicago Times, 1893, "The Princess and the Salmon."

Hampshire Gazette, 1893, "Old Hadley."

Evening Post, 1893, "The Ondawa" (Vermont) ; July 8, 1893, "A Boreal Arcadia ;"

September, 1893, "An Arctic Summer Trip" (Mackenzie River).

D. K. E. Quarterly, December, 1893, "Old Times in Achaia."

SPORTS Men's Review, 1894, "Old Kaat of Kaaterskill Clove."

Government Print, Washington, D. C., "Monograph of the Reindeer" (Agr. Dept.).

New England Magazine, February, 1894, "A Gentleman's Estate."

Forest and Stream, 1895, "The Pamlico Section" (six papers), "Christmas on the

Rio Grande."

Sportsmen's Review, 1895, "A June Rise on the Godbout."

Railway Age, 1895, "First Railroad Train in Florida."

Evening Post, 1896, "Red Lake Reservation."

Minneapolis Journal, 1896, "Game of Minnesota."

Sportsmen's Review, 1896, "Trip Over Mountain Tops" (North Carolina).

Samuels \& Kimball, Boston, 1897, "Cape Cod Way."

Forest and Stream, 1890, "On the Godbout, P. Q." (three papers.)

Raleigh News, 1898, "White Supremacy;" 1899, "The World's Greatest Explorer."

Mobile Register, 1900, "The Mobile Awakening" (five papers).

American Angler, 1900, "On the Nepigon," "Detroit and Pelican Lakes."

Fayetteville Observer, 1900, "Ancestral Homes of Our Negroes." 
Hampshire Gazette, 1900, "Courtship of Queen Victoria."

Jacksonville Times-Union, 1900, "St. Augustine Vestibuled Train Forty Years Ago." Nature's Realm, 1900, "First American Zoo;" 1901, "The Bison's Paradise."

Mobile Register, 1902, "Ice Architecture and Winter Carnivals."

American Sportsman, 1909, "The Bison as a Factor in Distributing Population."

Southold Traveler, 1909, "Eastern Long Island," "Ancient Landmarks," "Respect for Elders."

\section{NEIVSPAPER IVORK.}

New Haven Register................................... Editor

New York Journal of Commerce.

Augusta (Ga!) Chronicle and Senitinel.

Bermuda Royal Gazette................................

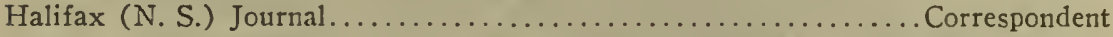
"Fditor

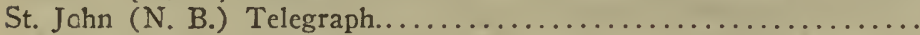

St. John (N. B.) Courier. "

St. John (N. B.) Humorist.

New York American Angler.

New York Nature's Realm..

New York Forest and Stream

St. Paul Field and Stream

St. Paul Pioneer Press.

New York Evening Post.

New York Times.

SPORTSMEN'S REVIEW. .

Harper's Weekly.

MeM.-Newspaper work fills two scrap books of ledger size.

\section{RAILROAD WORK.}

Worked up resources of Texas, Missouri, Michigan, Eastern Virginia, Tidewater North Carolina, Maritime Provinces, Minnesota, Idaho, Montana, Alaska, North Dakota, Manitoba, California, Western North Carolina and other states on the lines of Canadian Pacific, Missouri Pacific, Northern Pacific, Norfolk \& Southern, Chesapeake \& Ohio, Grand Rapids \& Indiana, Chicago \& Northwestern and Chicago, Milwaukee \& St. Paul Railroads.

\section{Escapes and Deliverances of Charles Hallock.}

1. Wife and I derailed at pitch-dark midnight in West Virginia, one ioot from Gurley River chasm, 90 feet deep.

2. Caught in a narrow rock cut at Kanawha Falls, W. Va., with an express train dashing through.

3. Run away with down hill at Lake Saltonstall, near New Haven, Conn., and saved by a miracle from plunging into deep water.

4. Derailed and train wrecked at midnight at Lyme, Conn.

5. Similar accident the next winter at Fort Worth, Tex.

6. Upset in Mississippi River at St. Paul. Money loss, $\$ 1,000$.

7. Run away with down Mt. Holyoke, Mass., and buggy smashed to atoms.

8. Fell forty feet from top of hemlock at Plaineld, Mass., and saved from being dashed on a rock below by an interposing dead limb which did not break. 
9. Saved from drowning at New Haven while bathing by Richard Sewell. Sank twice.

10. Steamer disabled by broken piston on Pacific coast. Half a revolution more would have driven the piston through the bottom. On lone island ten days.

11. Lightning struck Coliseum at Minneapolis, Minn., during Theodore Thonas' concert while wife was in it.

12. Lightning struck and wrecked home in Kingston, Canada, while I was in it.

13,14 . Three times lightnintg struck within a few feet of us both.

15. Narrow escape at Newbern, N. C.

16. Rusty nail in knee cap had to be pulled out by blacksmith's forceps. Three months on critches. Narrow escape from lockjaw.

17. Cannon burst and injured left hand, cutting cords.

18. Three-horse team swamped while crossing Sauk River, Minnesota, during flood. Everything lost.

19. Schooner driven through a shoal of rocky (Magdalen) islands in Gulf of St. Lawrence, during tremendous gale, without striking.

20, 21, 22. Artery of left wrist cut. Pitch fork tine in left instep. Wire file in palm of left hand. All serious and endangering life from lockjaw.

23. Jaw broken and eight teeth knocked out by blow from a ruffian at Coney Island, N. Y.

24. Ran blockade from Wilmington, N. C., under fire, without injury, in 1863.

25. Ran picket lines of both armies from Maryland to Virginia across Potomac and Rappahannock, in February, 1863.

26. Fell on back in Mill Stream while trout fishing. Laid up one month.

27. Fell on depot floor, Northampton, July 18, 1902. Sore for a month afterwards.

28. Put out head on Brooklyn elevated station platform to see if train was coming on the instant that express train dashed by. A fraction of a second sooner would have my brains scattered over the platform.

MEM.-God's mercy has been great! Must have spared me for some good reason. Perhaps fur some good purpose?

(Signed) Charles Hallock, August 1, 1909.

SUMMARY.

Copyrighted books. .......................................... 17

Magazine articles........................................... 45

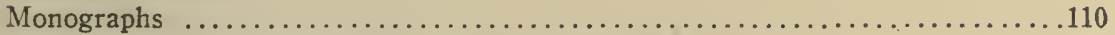

Occupations and experiments outside of newspaper work $\ldots \ldots \ldots \ldots \ldots \ldots \ldots$. 07

Correspondent and editor newspapers............................. 15

Hairbreadth escapes......................................... 28 


SOUTHERN REGIONAL LIBRARY FACILITY

Return this material to the library

rom which it was borrowed.

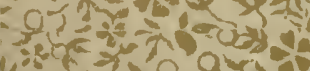

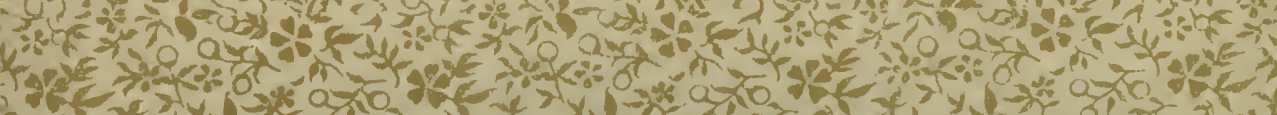

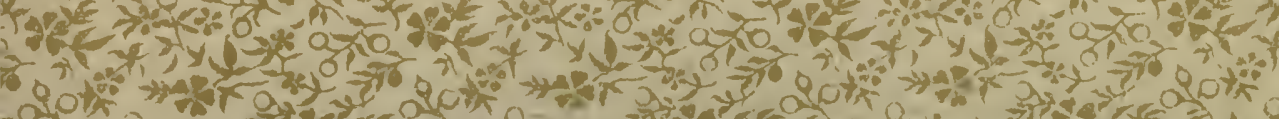
20
20 

Univers

South

Libr 